\title{
A Substantia Innominata-midbrain Circuit Controls a General Aggressive Response
}

\section{Authors}

Zhenggang Zhu, Qingqing Ma, Lu Miao, Hongbin Yang, Lina Pan, Kaiyuan Li, Ling-Hui Zeng, Xiaoxing Zhang, Jintao Wu, Sijia Hao, Shen Lin, Xiulin Ma, Weihao Mai, Xiang Feng, Yizhe Hao, Li Sun, Shumin Duan and Yan-qin Yu

\section{Correspondence}

duanshumin@zju.edu.cn (D.S.), yanqinyu@zju.edu.cn (Y.Y.Q.)

In Brief

Zhu et al. find that the posterior substantia innominata neurons universally drive aggressive behaviors by representing aggressive state and topography of aggression in mice.
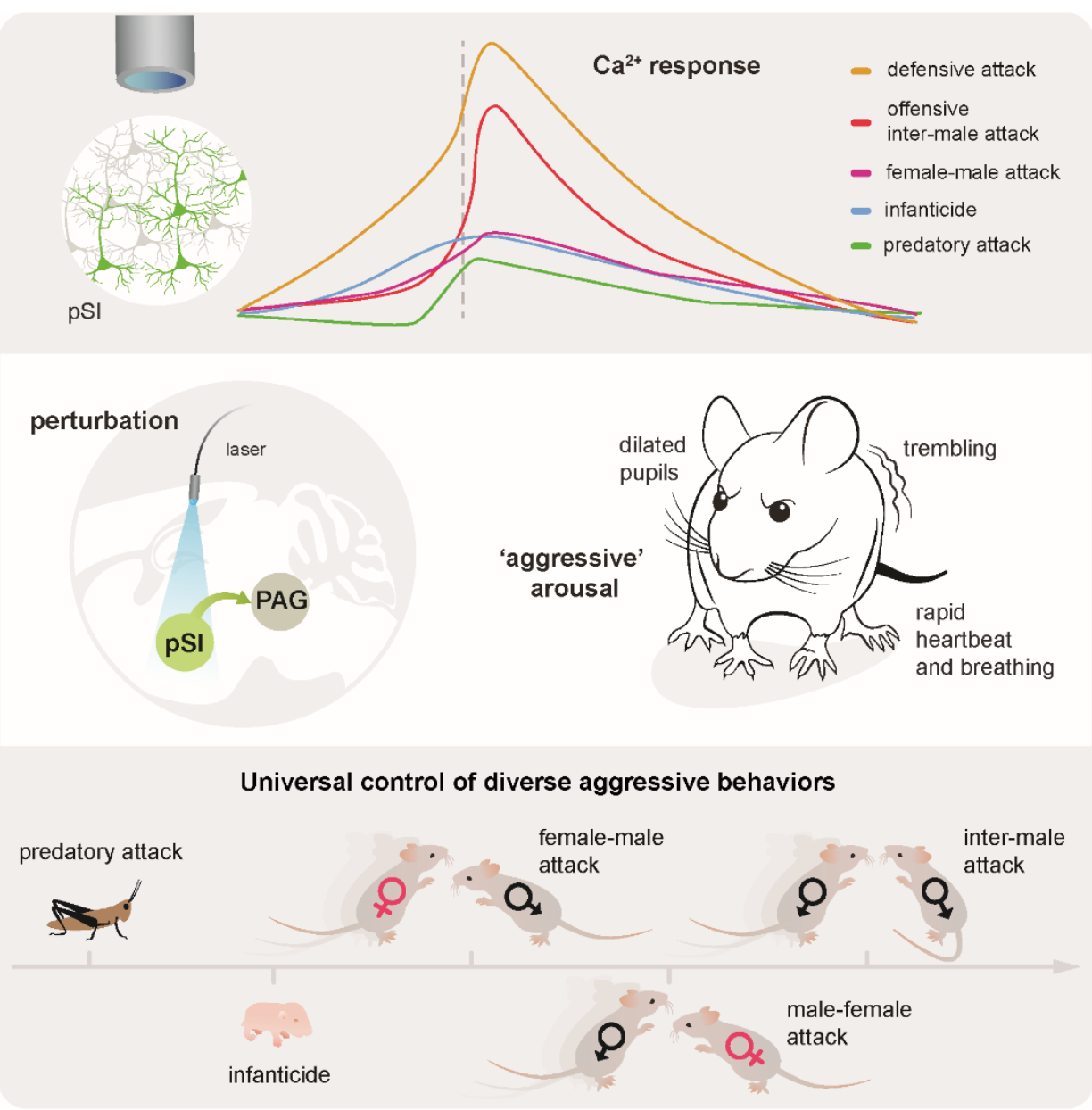

Highlights

- pSI neuronal dynamics reflect aggressive state and the topography of aggression

- The pSI-PAG circuit promotes arousal and elicits thirteen aggressive behaviors

- The pSI controls various aggressive behaviors in an activity level-dependent manner

- Inactivation of the pSI circuit blocks diverse aggressive behaviors but not mating 


\section{A Substantia Innominata-midbrain Circuit Controls a}

\section{General Aggressive Response}

Zhenggang Zhu ${ }^{1,2,6}$, Qingqing Ma ${ }^{1,2,6}$, Lu Miao ${ }^{1,2,6}$, Hongbin Yang ${ }^{1,2}$, Lina Pan ${ }^{1,2}$, Kaiyuan $\mathrm{Li}^{1,}$

${ }^{2}$, Ling-Hui Zeng ${ }^{3}$, Xiaoxing Zhang ${ }^{4}$, Jintao Wu ${ }^{1,2}$, Sijia Hao ${ }^{1,2}$, Shen Lin $^{1,2}$, Xiulin Ma ${ }^{1,2}$, Weihao Mai $^{1,2}$, Xiang Feng ${ }^{1,2}$, Yizhe Hao ${ }^{1,2}$, Li Sun $^{1,2}$, Shumin Duan ${ }^{1,2,5 *}$ and Yan-qin Yu ${ }^{1,2,7 *}$

${ }^{1}$ Department of Neurobiology and Department of Neurology of Second Affiliated Hospital, Zhejiang University School of Medicine, Hangzhou 310058, China

${ }^{2} \mathrm{NHC}$ and CAMS Key Laboratory of Medical Neurobiology, MOE Frontier Science Center for Brain Research and Brain-Machine Integration, School of Brain Science and Brain Medicine, Zhejiang University, Hangzhou, China

${ }^{3}$ Department of Pharmacology, School of Medicine, Zhejiang University City College, Hangzhou, Zhejiang, 310015

${ }^{4}$ Institute of Neuroscience and Key Laboratory of Primate Neurobiology, Shanghai Institutes for Biological Sciences, Chinese Academy of Sciences, Shanghai 200031, China.

${ }^{5}$ Research Units for Emotion and Emotion Disorders, Chinese Academy of Medical Sciences, Hangzhou, China

${ }^{6}$ These authors contributed equally

${ }^{7}$ Lead contact

*Correspondence: duanshumin@ zju.edu.cn (D.S.) and yanqinyu@ zju.edu.cn (Y.Y.Q.)

\section{SUMMARY}

While aggressive behaviors are universal and essential for survival, 'uncontrollable' and abnormal aggressive behaviors in animals or humans may have severe adverse consequences or social costs. Neural circuits regulating specific forms of aggression under defined conditions have been described, but how brain circuits govern a general aggressive response remains unknown. Here, we found that posterior substantia innominata (pSI) neurons responded to several aggression-provoking cues with the graded activity of differential dynamics, predicting the aggressive state and the topography of aggression in mice. Activation of pSI neurons 
projecting to the periaqueductal gray (PAG) increased aggressive arousal and robustly initiated/promoted all the types of aggressive behavior examined in an activity level-dependent manner. Inactivation of the pSI circuit largely blocked diverse aggressive behaviors but not mating. By encoding a general aggressive response, the pSI-PAG circuit universally drives multiple aggressive behaviors and may provide a potential target for alleviating human pathological aggression.

\section{KEYWORDS}

Posterior substantia innominata, periaqueductal gray, aggression, aggressive state, arousal, female, defensive behavior

\section{INTRODUCTION}

2 Animals exhibit a range of aggressive behaviors (Moyer, 1968, Blanchard et al., 2003) essential

3 for survival and reproduction (Nelson and Trainor, 2007), while pathological aggression causes serious social problems (Coccaro, 2012, Davidson et al., 2000). Distinct regions in the mouse

5 brain are essential for male, female, predatory, and infant-directed aggressive behaviors

6 (Lischinsky and Lin, 2020, Siegel and Victoroff, 2009). Furthermore, brain regions that have

7 been examined for more than one type of aggressive behaviors suggest that distinct neural

8 circuits might regulate aggression under specific internal and external conditions (Han et al.,

9 2017, Yang et al., 2017, Hashikawa et al., 2017, Chen et al., 2019). For example, aggression

10 initiated in the ventromedial hypothalamus (VMH) requires a specific genetic background,

11 sexual-reproductive state, and social-contextual conditions (Yang et al., 2017, Lee et al., 2014,

12 Hashikawa et al., 2017). On the other hand, social behavior-related conditions activated similar

13 brain structures and overlapping circuits (Hashikawa et al., 2017, Kim et al., 2015, Lin et al., 
2011, Dulac et al., 2014). Furthermore, stereotyped attack displays (e.g., biting, chasing, and aggressive arousal) are expressed in most aggressive behaviors (Hashikawa et al., 2018, Siegel and Victoroff, 2009), implying the involvement of some neural pathways for diverse aggressive behaviors. Besides, human pathological aggression is characterized by a variety of inappropriate and uncontrollable impulsive attacks (Coccaro, 2012) that may break out in the absence of an external threat, implying that some circuits in the brain may encode a general aggressive response. However, whether such synergistic circuits exist in the brain and how they regulate the internal state and behavioral activity patterns that together comprise diverse aggressive behaviors remain unclear.

The amygdala is a key node for regulating aggression-related emotional states (McCloskey et al., 2016, Davidson et al., 2000). However, the role of subdivisions of the amygdala in diverse aggressive behaviors and aggressive states remains elusive. The substantia innominata (SI), a sub-region of the basal forebrain that extends $>2 \mathrm{~mm}$ rostrocaudally in the mouse brain (https://bbp.epfl.ch/nexus/cell-atlas/), can be divided into the anterior SI (aSI) and the posterior SI (pSI) (Figure S1), which has also been classified as the extended amygdala (Heimer et al., 1997, Grove, 1988a). Remarkably, the SI is also involved in the regulation of motivation and fear behaviors (Yu et al., 2017, Cui et al., 2017), the aggression-related emotional state.

Using electrophysiological recording and $\mathrm{Ca}^{2+}$ imaging, we found that mouse pSI neurons exhibited increased activity with differential intensity and dynamics. This graded neuronal activity was correlated with the biological significance (threatening/attack-provoking or neutral) of the different social-contextual cues and predicted the topography of diverse aggressive behaviors. Acute optogenetic or pharmacogenetic manipulation of pSI neurons projecting to PAG demonstrated that the pSI-PAG circuit universally controls diverse aggressive behaviors.

\section{RESULTS}




\section{Posterior SI Neurons Are Highly Active During Inter-male Aggression}

To explore the role of SI in mouse aggressive behaviors, we first examined the c-Fos expression of c-Fos+ neurons in the pSI under aggressive conditions was $\sim 3.4$-fold greater than that under the control investigating condition, while less of an increase occurred in the aSI, nearby central amygdala (CeA), and globus pallidus (GP) (Figures 1B, 1C).

We found that approximately $81 \%$ of the aggression-induced c-Fos+ neurons in the pSI were thymus cell antigen 1-positive (Thy1+), and 77\% were calcium/calmodulin-dependent protein recordings of the pSI neuronal activity during non-aggressive and aggressive social behaviors (Figures 1F, 1G). The average firing rate of all the recorded pSI neurons $(n=113)$ was increased during aggression (Figures $1 \mathrm{H}-1 \mathrm{~J}$ ), with $39 \%$ showing increased activity during an attack (Figure 1H), which was much higher than that during a sniff (Figure 1H). Notably, activity in these aggression-excited pSI neurons started to increase during the sniff preceding an attack (Figures $1 \mathrm{~K}, 1 \mathrm{~L})$. The pSI neurons excited with aggression were less activated when sniffing an object $(22 \%$, Figure $1 \mathrm{M})$ than when sniffing a male mouse (38\%, Figure $1 \mathrm{~N})$. Moreover, we found that pSI neurons excited by sniffing a male, a provoking cue for aggression, were activated more in attacks than the excitation when sniffing an object (Figures 1O-1R; 47\% vs 35\%). Interestingly, none of the recorded neurons showed an increased firing rate under all three conditions (Figures

57 1S, 1T). In summary, we found that pSI neurons are highly active in inter-male aggression, and these neurons may encode the aggression and aggression-provoking cues.

States in Inter-male Aggression

61 To further explore the correlation between the activity in identified subtypes of pSI neurons and 
aggression, we injected viruses encoding GCaMP6m into the pSI of male Thy1-Cre mice $(\mathrm{FVB} / \mathrm{N})$ and used fiber photometry to record $\mathrm{Ca}^{2+}$ signaling in $\mathrm{pSI}^{\text {Thy1 }}$ neurons during various social behaviors (Figures 2A, 2B, and S2A, S2B). Male Thy1-Cre mice exhibited robust aggressive behaviors (mean duration, $1.01 \pm 0.06 \mathrm{~s}$; Figures S2C, S2D). The activity of pSI ${ }^{\text {Thy1 }}$ neurons started to increase before an attack ( -1.2 s, pre-attack), peaked midway through the attack (duration of attacks, $\sim 1.0 \mathrm{~s}$; peak magnitude $(\Delta \mathrm{F} / \mathrm{F}): 23.43 \%)$ and was sustained for some time after termination of the attack ( 4.8 s; post-attack, Figures S2E-S2H). Remarkably, distinct $\mathrm{Ca}^{2+}$ dynamics of $\mathrm{pSI}^{\text {Thy1 }}$ neurons were found in attacks of different patterns or different episodes of continuous attacks (Figures S2I-S2P).

Differential $\mathrm{Ca}^{2+}$ dynamics in the $\mathrm{pSI}^{\mathrm{Thy} 1}$ neurons were also recorded during other types of social behaviors such as sniffs and rattles, depending on whether these behaviors were followed by attack behavior (Figures $2 \mathrm{~A}, 2 \mathrm{~B}$ ). $\mathrm{Ca}^{2+}$ activity in the $\mathrm{pSI}^{\mathrm{Thy} 1}$ neurons increased more during the sniff/rattle preceding an attack (peak $\Delta F / F: 21.23 \% / 17.37 \%$ ) than the simple sniff/rattle without an attack (9.90\%/7.03\%; Figures 2C-2F, and 2I-2J). $\mathrm{Ca}^{2+}$ levels associated with these sniffs or rattles predicted whether or not an actual attack would follow (Figures 2G-2H and 2M$2 \mathrm{~N})$. When mice threatened male intruders, the $\mathrm{pSI}^{\text {Thy1 }}$ neuronal activity also increased to a high level (17.06\%), similar to that in 'aggressive' rattles (Figures $2 \mathrm{~K}, 2 \mathrm{~L}$ ).

Collectively, $\mathrm{pSI}^{\mathrm{Thy} 1}$ neurons showed a graded increase in $\mathrm{Ca}^{2+}$ activity in various inter-male social behaviors, with the least increase during 'non-aggressive' social behaviors such as a simple sniff or rattle, relatively high activity during 'aggressive' inter-male social behaviors such as sniff-attack or rattle-attack, and the highest activity in inter-male attacks (Figures $2 \mathrm{O}$ and S2). These behaviors in different aggressive states were largely predicted by the associated $\mathrm{pSI}^{\text {Thy } 1}$ neuronal activity (Figures 2P, 2Q, and S2).

Graded $\mathrm{Ca}^{2+}$ Activity in pSI ${ }^{\text {Thy1 }}$ Neurons Associated with Various Aggression-provoking 


\section{Cues and Different Aggressive Behaviors}

87 Next, we investigated whether aggressive behaviors in male Thy1-Cre mice could be evoked by different social-contextual cues (Figure S4A) and how $\mathrm{pSI}^{\text {Thy1 }}$ neurons responded to various cues that may or may not trigger aggression (Figure S4E). We found that various imminent non-social threat cues but not neutral or appetitive stimuli significantly activated the $\mathrm{pSI}^{\text {Thyl }}$ neurons (Figures S4F-S4I) and moderately evoked aggressive behaviors (Figures S4B-S4D). Moreover, introducing a conspecific into the home cage of a tested male mouse (Figure S4C) frequently evoked aggressive behaviors and immediately induced even higher activity in $\mathrm{pSI}^{\text {Thy1 }}$ neurons than non-threat social cues (Figures S4J-S4N). Interestingly, the introduction of different types of the conspecific evoked differential intensity of $\mathrm{pSI}^{\text {Thy1 }}$ neuronal activity in the order (from weak to strong) female C57 < male C57 < male CD1 < male C57 with a subsequent attack (Figure S4O).

We next investigated whether and how $\mathrm{Ca}^{2+}$ activity in $\mathrm{pSI}^{\mathrm{Thy} 1}$ neurons correlates with different types of aggressive behavior (Figure 3A). First, we recorded the neural activity during male-female attacks when Thy1-Cre male mice occasionally attacked female mice (observed in $22.7 \%$ of mice, Figure $3 \mathrm{~B})$. We found that $\mathrm{pSI}^{\mathrm{Thy} 1}$ neuronal activity was increased during a malefemale attack with a time window from $-1.7 \mathrm{~s}$ to $7.5 \mathrm{~s}$ (Figure $3 \mathrm{C}$ ) and peak magnitude similar to that in inter-male attacks (25.62\% vs $23.43 \%$, Figures 3D and S2F, S2G). When introduced to the home-cage of male CD-1 mice and attacked by the latter, the Thy1-Cre mice in turn exhibited defensive attacks. Interestingly, the increased neural activity during inter-male defensive attacks (peak $\Delta F / F: 30.23 \%$ ) was even higher than that during inter-male offensive attacks (Figures 3E3G). In contrast, although the $\mathrm{pSI}^{\text {Thy1 }}$ neuronal activity was also increased in predatory attacks on crickets, the increase was much less and shorter in sustained time (from $-0.2 \mathrm{~s}$ to $3.3 \mathrm{~s}$ ) than that 
109 in inter-male attacks (Figures $3 \mathrm{H}-3 \mathrm{~L}$ ). The increased pSI $^{\text {Thy1 }}$ neuronal activity in pup-directed

110 attacks had a similar magnitude but a longer time window (from $-2.1 \mathrm{~s}$ to $4.8 \mathrm{~s}$ ) than that in a

111 predatory attack (Figures 3M-3Q). The female aggression in virgin female mice toward a male

112 mouse, although seldom observed and lasting for a shorter time (duration in females vs males:

$1130.42 \mathrm{~s} v s 1.01 \mathrm{~s}$ ) (Figures 3T, 3V and S2E), was associated with increased pSI ${ }^{\text {Thy1 }}$ neuronal

114 activity at a similar amplitude but an even longer time window (from $-4.0 \mathrm{~s}$ to $7.5 \mathrm{~s}$ ) than with

115 predatory or pup-directed aggression (Figures $3 \mathrm{R}-3 \mathrm{~V}$ ). The $\mathrm{pSI}^{\text {Thy1 }}$ neuronal $\mathrm{Ca}^{2+}$ properties in

116 cricket-directed, pup-directed, and female social behaviors were used to nicely classified the

117 sniffs, sniffs (attack), and attacks (Figures 3K, 3P, 3U) and predicted whether or not an actual

118 attack would follow (Figures S3L-S3AA). Interestingly, the decoding accuracy in the 4 types of

119 attack and approach (attack) was much higher than those in the 4 types of approach (Figures S3X,

$120 \mathrm{~S} 3 \mathrm{Y})$. Moreover, $\mathrm{pSI}^{\mathrm{Thy} 1}$ neurons in the tested mice showed graded increases in activity in the

121 order (from weak to strong) predatory aggression < pup-directed aggression < female aggression

122 < male offensive aggression < male defensive aggression (Figures S3Z, S3AA).

123 In summary, the perception of various aggression-provoking cues and the topography of

124 aggressive behaviors are critical elements of the magnitude and dynamics of pSI $^{\text {Thy } 1}$ neuronal

125 activity.

Activation of pSI Neurons Drives Inter-male Aggression and Enhances Autonomic Arousal

127 We then asked whether the activation of $\mathrm{pSI}^{\text {Thy1 }}$ neurons is sufficient to elicit aggression. The

128 hM3Dq-encoding virus injected male mice were intraperitoneally injected (i.p.) with clozapine-

129 N-oxide (CNO) to pharmacogenetically activate the $\mathrm{pSI}^{\mathrm{Thy} 1}$ neurons (Figures $4 \mathrm{~A}, 4 \mathrm{~B}$ ). CNO

130 treatment robustly induced aggressive behaviors in mice (Figures 4C and S5S). Interestingly, no

131 mating behavior was observed (Figure 4C). Using the anterograde trans-synaptic tracing

132 approach, we found that ventral lateral/lateral PAG (VL/LPAG), a region involved in the motor 
control of social behaviors (Behbehani, 1995), was densely innervated by pSI neurons (Figures S5A-S5D) (also see http://www.brain-map.org experiment id: 120281646) (Grove, 1988a). We further labeled the input neurons to the PAG by injecting a retrograde AAV-Retro-EGFP virus into the VL/LPAG (Figure 4D). A dense infection of upstream neurons was found in the pSI, but not or few in the aSI, GP, or MeA (Figures 4D, 4E). Most of the pSI neurons projecting to the PAG (pSI ${ }^{-P A G}$ neurons) were Thy1-positive or CaMKII $\alpha$-positive ( 87\%/77\%, Figures S5E-S5H), and chemogenetic activation of the $\mathrm{pSI}^{\mathrm{PAG}}$ neurons (Figures S5I-S5O) robustly elicited intermale aggression, but no mating behavior was observed (Figures S5P-S5R).

We next used an optogenetic approach to establish a causal relationship between $\mathrm{pSI}^{-\mathrm{PAG}}$ neuronal activity and aggressive behaviors with more precise temporal resolution (Figures 4F and S6A-S6C). A socially-housed male that exhibited minimal natural inter-male aggression (Figure 4G) immediately attacked a singly-housed male (Figures 4H and S6G; Movie S1) when $\mathrm{pSI}^{-\mathrm{PAG}}$ neurons were optogenetically activated (Figures S6D-S6F). Notably, the light-evoked attack was characterized by biting an opponent's dorsal surface at a mean latency of $\sim 3 \mathrm{~s}$ (Figure 4I), resembling the most violent natural aggressive behavior (Figure S2). Optogenetic activation of $\mathrm{pSI}^{\mathrm{CaMKII} \alpha}$ neurons (Figures S6P-S6T) or PAG projecting $\mathrm{pSI}^{\text {Thy1 }}$ neurons (Figure S7) similarly increased male aggression.

Diverse types of aggression may be primarily classified into proactive and affective forms, characterized by hypoarousal and hyperarousal, respectively (Siegel and Victoroff, 2009). We next determined whether the photoactivation of $\mathrm{pSI}^{-\mathrm{PAG}}$ neurons modulates arousal (Figures $4 \mathrm{~J}$, 4K) (Wang et al., 2015). Photoactivation of the $\mathrm{pSI}^{-\mathrm{PAG}}$ neurons resulted in a significant ( 30\%) increase in pupil size (Figures 4L, 4M; Movie S2), a response that was sustained for $>15 \mathrm{~s}$ after the stimulation ceased. The eyes were also wider during pSI stimulation (Figure 4N; Movie S2). Moreover, $\mathrm{pSI}^{-\mathrm{PAG}}$ activation caused an increase in the breathing rate (Figure 4O) and heart rate 
157 (Figure 4P), as well as body trembling (Figure 4Q; Movie S2). However, the photostimulation of $158 \mathrm{pSI}^{-\mathrm{PAG}}$ neurons did not affect the overall level of anxiety (Figures S6I, S6J), nor trigger the 159 freezing or flight response (Figures S6K-S6O). In summary, optogenetic activation of $\mathrm{pSI}^{-\mathrm{PAG}}$ 160 neurons immediately induced robust attacks accompanied by an increased arousal state (Figure 161 4R), a response consistent with affective aggression (Siegel and Victoroff, 2009).

\section{Diverse Aggressive Behaviors Controlled by Differential Activity of pSI-PAG Neurons}

We reasoned that the increased arousal induced by pSI activation might establish a 'heightened aggressive arousal' that overcomes the internal and external requirements for evoking multiple types of aggression (Moyer, 1968). In the subsequent experiments, we determined whether the photo-activation of $\mathrm{pSI}^{-\mathrm{PAG}}$ neurons induces a variety of aggressive behaviors under various conditions (Figure 5A).

Offensive inter-male aggression is expressed distinctly when animals are under different social-contextual conditions (Yang et al., 2017, Zelikowsky et al., 2018). Surprisingly, photoactivation of $\mathrm{pSI}^{-\mathrm{PAG}}$ neurons not only facilitated typical territorial inter-male aggression in both singly-housed (Figure 5J) and socially-housed (Figure 4) resident mice in their home cages but also in a novel cage (Figure 5J) or even when a socially-housed male encountered its male cage mate (Figure 5J). Notably, photoactivation of pSI $^{-\mathrm{PAG}}$ neurons even induced inter-male aggression when the optogenetically activated male mice intruded into the home cage of another mouse (Figure 5J). Under normal conditions, male mice do not attack females (Lin et al., 2011).

176 Interestingly, photoactivation of $\mathrm{pSI}^{\mathrm{PAG}}$ neurons reliably induced male aggression against 177 females to an extent similar to attacks against males (Figure 5J). Strikingly, pSI-activation in 178 virgin females, which rarely express aggression, immediately initiated attacks against males 179 (Figures 5B-5C; Movie S3) or females (Figure 5J).

180 We found that photoactivation of $\mathrm{pSI}^{-\mathrm{PAG}}$ neurons in sexually-experienced males evoked 
aggression toward pups (Figures 5D, 5E), an infanticidal behavior usually committed by adult virgin males but not sexually-experienced males (Isogai et al., 2018). Photoactivation of pSI $^{-\mathrm{PAG}}$ neurons increased predatory attacks in male mice toward crickets (Figure 5J). Interestingly, photoactivation of $\mathrm{pSI}^{-\mathrm{PAG}}$ neurons also induced object-directed aggression (Figures 5F, 5G): a moving glove evoked a rage-like response in male mice that never occurred in control mice (Lin et al., 2011). A socially-housed male that had been previously socially defeated by a more aggressive CD-1 male for 5 min would flee or freeze without apparent aggression (Blanchard et al., 2003) when encountering the same CD-1 mouse later in the home cage of that CD-1 mouse (Movie S4). Surprisingly, photoactivation of $\mathrm{pSI}^{-\mathrm{PAG}}$ neurons in the defeated mouse immediately shifted the flight or freeze into a defensive attack towards the aggressive CD-1 male (Figures 5H-5I; Movie S4). No increased mating behavior was observed under the above conditions. Optogenetic or pharmacogenetic activation of $\mathrm{pSI}^{\mathrm{CaMKII} / \mathrm{Thy} 1}$ neurons similarly increased the rarely-observed male or female aggression (Figure S8). Furthermore, photoactivation of the $\mathrm{pSI}^{-}$ ${ }^{\mathrm{PAG}}$ or $\mathrm{pSI}^{\mathrm{CaMKII} \alpha}$ neuronal projection terminals in the PAG, but not in the other two downstream target areas related to aggression, bed nucleus of the stria terminalis (BNST) or VMH (Lin et al., 2011) (Figure S9), triggered diverse aggressive behaviors (Figure S10).

Notably, the extent of an attack was similar among the above thirteen types of aggressive behaviors (Figure 5J) induced by the photoactivation of $\mathrm{pSI}^{-\mathrm{PAG}}$ neurons at the same intensity of laser stimulation $(2.7 \mathrm{~mW})$. Considering that graded neuronal responses of pSI neurons were recorded during natural aggressive behaviors (Figure 3), we investigated whether multiple aggressive behaviors could be elicited by different activities of $\mathrm{pSI}^{-\mathrm{PAG}}$ neurons (Figure 6A). We found that the strength of photoactivation was strongly correlated with the attack probability or latency to attack onset among all aggressive behaviors tested (Figures 6B-6G). However, distinct dose-response curves, obtained by non-linear regression fit of photostimulation intensity with the 
probability and latency of attack, were created from these five types of evoked aggression (Figures 6F-6G). Low-intensity photostimulation $(<0.2 \mathrm{~mW})$ mostly initiated predatory and pupdirected aggression, with less evoked female aggression and the least triggered male aggression (Figures 6F-6H). As the stimulation intensity increased to intermediate light intensities $(0.2-1$ $\mathrm{mW}$ ), female-male, male-female, and inter-male aggression were more frequently evoked (Figures 6F, 6G). Moreover, under conditions of high-intensity photostimulation (>1 mW), all five types of aggressive behaviors were triggered (Figures 6F-6G and 5J). Thus, diverse aggressive behaviors are differentially initiated by scalable activation of $\mathrm{pSI}^{-\mathrm{PAG}}$ neurons, with the different threshold in the order: predatory aggression < pup-directed aggression < female aggression $<$ inter-male aggression (Figure $6 \mathrm{H}$ ). We next traced the upstream of $\mathrm{pSI}^{-\mathrm{PAG}}$ neurons (Figure S11) and found that $\mathrm{pSI}^{\mathrm{PAG}}$ neurons receive direct innervations from many areas (such as VMH, MeA, BNST) involved in aggressive or social cue-induced behaviors (Lin et al., 2011). Interestingly, the threshold of aggressive behaviors induced by activation of $\mathrm{pSI}^{-\mathrm{PAG}}$ neurons was elevated after the acute social defeat (Figure S12), suggesting the $\mathrm{pSI}^{-\mathrm{PAG}}$ neurons can be modulated by social stress.

Together, the causal relationship of the graded $\mathrm{pSI}^{-\mathrm{PAG}}$ neuronal activity with diverse aggressive behaviors, the dynamics (Figure 3), and anatomical evidence of $\mathrm{pSI}^{-\mathrm{PAG}}$ neurons suggest that pSI activity represents a threshold variable for computing diverse aggressive behaviors.

\section{pSI Is Required for Diverse Aggressive Behaviors but not for Mating}

We then asked whether the pSI is also necessary for these natural aggressive behaviors. We first optimized a behavioral paradigm in which a singly-housed male in its home cage robustly attacked a socially-housed male intruder (Figure 7A). Pharmacogenetically inhibiting the pSI ${ }^{\text {Thy1 }}$ neurons (Figures 7B-7E and S13H-S13L) and the pSI ${ }^{-\mathrm{PAG}}$ neurons (Figures S13A-S13G) largely 
blocked the aggression but not mating.

Strikingly, photo-inhibition of $\mathrm{pSI}^{\mathrm{Thy} 1}$ neurons (Figures $7 \mathrm{~F}$, and $\mathrm{S} 13 \mathrm{H}-\mathrm{S} 13 \mathrm{~J}$ ) by targeting the Cre-dependent expression of Guillardia theta anion channelrhodopsin 1 protein (GtACR1) immediately terminated inter-male offensive aggression when a singly-housed male in its home cage encountered a socially-housed male (Figures 7G, 7J, 7M; Movie S5). Optogenetically inhibiting $\mathrm{pSI}^{\mathrm{Thy} 1}$ neurons decreased the pup-directed aggression in singly-housed virgin adult males (Figures 7H, 7K, 7M). Similarly, photo-inhibition of $\mathrm{pSI}^{\text {Thy1 }}$ neurons reduced the predatory aggression when a socially-housed male was attacking crickets (Figures 7I, 7L, 7M). The probability of interruption was similar among these aggressive behaviors blocked by pSIinhibition (Figure $7 \mathrm{~N}$ ). Silencing $\mathrm{pSI}^{\text {Thy1 }}$ neurons by photo-inhibition also significantly reduced the male-female and female-male aggression (Figures S14A-S14H), but running and feeding behaviors were not affected (Figures S14I-S14P).

\section{DISCUSSION}

We have identified the pSI as a previously-unappreciated key center for regulating diverse aggressive behaviors in mice. Upon perception of various social-contextual cues, pSI neurons increased their activity with graded intensity and differential dynamics in a manner that nicely predicted and determined the states and topography of diverse aggressive behaviors.

\section{The pSI Circuit Controls a Scalable Aggressive State}

Social behaviors like aggression are believed to be tightly associated with internal states (Anderson, 2016, Asahina et al., 2014, Zelikowsky et al., 2018). Several lines of evidence indicated that the pSI circuit controls a scalable aggressive state by integrating various attackrelated social-contextual cues, and activity-dependently drives multiple aggressive behaviors. First, the activity of $\mathrm{pSI}^{\mathrm{Thy} 1}$ neurons increased in the following situations: 1 . when mice were 
exposed to aggression-provoking aversive cues, but not with appetitive and neutral stimuli (Figure S4); 2. when mice actively contacted intraspecific and interspecific targets (sniff-attack and rattle-attack; Figures 2 and 3); and 3. before, during, and after the mice executed attacks (Figures 2, 3 and S2). Second, the initiation, termination, and topography of an attack were decoded by the $\mathrm{pSI}^{\text {Thy1 }}$ neuronal activity (Figures 2, 3 and S2, S3). Third, the increased neuronal activity induced by various cues was graded in intensity and differed in dynamics, depending on the saliency of various attack-related cues, such as the 'threat' level of the cues (Figure S4) and the nature of the attacked targets (Figure 3). Finally, the activation of $\mathrm{pSI}^{-\mathrm{PAG}}$ neurons not only triggered aggression but also increased autonomic arousal (Figure 4), an internal state correlated with aggressive behavior in flies and mice (Anderson, 2016, Asahina et al., 2014), defensive rage in cats (Siegel and Victoroff, 2009), and impulsive aggression in humans (Coccaro, 2012). An increased internal aggressive state may explain our finding that attacks induced by the activation of pSI neurons were directed at a variety of targets within the visual field, including a moving glove, crickets, and conspecific male or female mice (Figures 5, 6).

Notably, pSI shows a graded neuronal response that scales with multiple behavioral states rather than a 'binary state' (of the neurons that are only active during aggression and not in other contexts). This property may help the pSI to orchestrate other complex behaviors so as to decide whether attack or not to attack. Similar neural responses have been observed recorded in other behavioral state-defined neurons, such as 'hunger' neurons in the arcuate nucleus (Chen et al., 2015) and 'parenting' neurons in the preoptic area (Kohl et al., 2018).

\section{The pSI Circuit Governs Multiple Forms of Aggression}

Various aggressive behaviors with specific displays are crucial ways to resolve conflicts for survival and reproduction and may have distinct neural circuitry mechanisms (Han et al., 2017, Yang et al., 2017, Hashikawa et al., 2017, Chen et al., 2019). For example, animals may respond 
277 with different levels of attacks when encountering a social threat, including displaying

278 substantial offensive or defensive attack response initially and shifting aggression to defensive

279 freezing or flight after the social defeat (Blanchard and Blanchard, 1988, Blanchard et al., 2003).

280 We found that activation of pSI in a defeated mouse immediately shifted the defensive response

281 to a robust attack pattern (Figure 5). Stronger stimulation of the pSI was required for an offensive

282 attack after successive social defeats (Figure S12). These together highlight the conclusion that

283 pSI neurons are critical for coping with a social threat by expressing attacks and can be 284 modulated by past social stress.

VMH initiated-attacks in mice are affected by the singly- or socially- housing conditions

(Yang et al., 2017), genetic background, and reproductive status (Hashikawa et al., 2017).

Neurons in the central amygdala (Han et al., 2017) or zona incerta (Shang et al., 2019, Zhao et al., 2019) triggers predatory but not intra-conspecific aggression. Here, we demonstrate that the activation of $\mathrm{pSI}^{-\mathrm{PAG}}$ neurons universally controls diverse aggressive behaviors, bypassing genetic background, reproductive state, social-contextual conditions, or opponent type required aggressive behaviors reported previously. It is plausible that the pSI-PAG circuit acts further downstream of the aggression-controlling pathway than the dedicated circuits for controlling behaviors. 
2014) and MeA (Hong et al., 2014) neurons control several social behaviors, including attack, social investigation, and mounting in an intensity-dependent manner. Also, medial preoptic area neurons (Wu et al., 2014, Park et al., 2018) and MeA neurons (Chen et al., 2019) have been correlated with both aggression and parenting behaviors. Notably, we found that $\mathrm{pSI}^{-\mathrm{PAG}}$ neurons specifically regulate various aggressive behaviors but not mating, consistent with SI is much higher activated after aggression than after mating (Lin et al., 2011). Given the heterogeneous cell types in the pSI (http://mouse.brain-map.org/), it will be intriguing to know whether and how different populations of pSI neurons may encode opposing internal states of aggression and other social behaviors.

Many hypothalamic, amygdala, and midbrain regions directly connect with the pSI circuit (Figures S9 and S11) (Grove, 1988b, Grove, 1988a, Cui et al., 2017). For example, the pSI sends strong output to the aggression-related PAG and nearby BNST (Lin et al., 2011, Hashikawa et al., 2017, Mos et al., 1982, Padilla et al., 2016). Interestingly, our results indicate that the VL/LPAG, but not the BNST or VMH, is a downstream pathway through which the pSI can execute aggression and may function as a circuit dedicated to the finely-tuned, dynamically-controlled behavioral components of executing attack actions (Arber, 2012, Tovote et al., 2016, Falkner et al., 2020). It will be of great interest to explore whether the pSI directly receives and integrates convergent aggression-related information from these aggression-related circuits and sends out divergent signals to downstream pathways to execute these behaviors.

\section{Potential Relevance to Pathological Aggression}

Abnormal aggressive arousal and an inability to control aggressive behaviors appropriately, such as "Intermittent Explosive Disorder" in humans, are serious social problems that still lack efficient interventional approaches (Siegel and Victoroff, 2009, Davidson et al., 2000). Various inappropriate aggressive behaviors induced by the pSI in mice could serve as an animal model of 
pathological aggression. Interestingly, abnormalities of the human amygdala are closely associated with pathological aggression (McCloskey et al., 2016, Nelson and Trainor, 2007, Coccaro, 2012, Davidson et al., 2000). As a conserved sub-region of the human amygdala (see http://atlas.brain-map.org/) and a necessary node for mouse aggressive behaviors, the pSI circuit may thus provide a therapeutic target for the suppression of human pathological aggression.

\section{ACKNOWLEDGMENTS}

We thank Xiaohong Xu, Bo Li, Hailan Hu, Dayu Lin, and Nirao M Shah for discussions and reading the manuscript. We thank Hui-Fang Lou, Li-Ya Zhu, Xiaohong Xu, Hao-Ran Wang, WeiQian Jiang, and Hai-Shan Yao for technical support. This work was supported by the National Key Research and Development Program (2016YFA0501000 and 2016YFC1306700), the National Natural Science Foundation of China (81821091, 31771167, 31970939, and 81527901), the Non-profit Central Research Institute Fund of the Chinese Academy of Medical Sciences (2018PT31041), Science and Technology Planning Project of Guangdong Province (2018B030331001 and 2019B030335001), The Key Research and Development Program of Zhejiang Province (2020C03009), and Fundamental Research Funds for the Central Universities (2019FZA7009).

\section{AUTHOR CONTRIBUTIONS}

Conceptualization, Z.G., Y.Y.Q., and D.S.; Methodology, Z.G., Y.Y.Q., and D.S.; Software, Z.G.; Formal Analysis, Z.G., M.L., Z.X., and M.X.; Investigation, Z.G., M.Q., M.L., P.L., L.K., W.J., Y.H., L.S., H.Y., M.W., F.X., L.S., and H.S.; Visualization, Z.G., M.Q., M.L., P.L., and L.K.; Writing Original Draft, Z.G., Y.Y.Q., and D.S.; Writing Review \& Editing, Z.G., L. H.Z., Y.Y.Q., and D.S.; Funding Acquisition, Y.Y.Q., and D.S.; Resources, Y.Y.Q., and D.S.; Supervision, Z.G., Y.Y.Q., and D.S.

\section{DECLARATION OF INTEREST}


The authors declare that they have no competing financial interests.

350

351

352

353

354

355

356

357

358

359

360

361

362

363

364

365

366

367

368

369

370

371

372

373

374

375

376

377

378

379

380

\section{MAIN FIGURES, FIGURE LEGENDS}

\section{Figure 1. Elevated Neuronal Activity in the pSI during Inter-male Aggression}

(A) Schematic of c-Fos analysis after sniff or attack.

(B) c-Fos+ neurons per slice in the pSI, aSI, CeA, and GP.

(C) Example images of c-Fos+ neurons (green) in the pSI after sniff (middle) or attack (bottom) (scale bars, $100 \mu \mathrm{m}$ ). CeM, medial division of CeA.

(D) Upper, example image of c-Fos+ (magenta) and Thy1+ (green) neurons in the pSI after aggression (scale bar, $100 \mu \mathrm{m}$ ); Lower, magnified image (scale bar, $20 \mu \mathrm{m}$ ).

(E) Left, percentage of c-Fos+ neurons co-localized with Thy1, CaMKII $\alpha$, ChAT, or GAD67 after an attack. Right, percentage of Thyl+ or CaMKII $\alpha+$ neurons expressing c-Fos after an attack.

(F) Schematics of in vivo recording of pSI neuronal activity during social behaviors.

(G) Representative image of electrode placement (upper, scale bar, $100 \mu \mathrm{m}$ ) and overlay of electrode placements in the pSI (lower).

(H) Relative proportions of neurons excited (red), inhibited (blue), or unaffected (gray) while contacting an object, sniffing, or attacking a male mouse.

(I) Heatmap of normalized firing rates of pSI neurons related to aggression.

(J) Mean population activity (Area under the curve, AUC) before, during, and after an attack for all recorded neurons in all attacks examined.

(K) Z-score of the firing rate of the neurons excited by aggression.

(L) AUC per second before, during, and after an attack for neurons excited by aggression.

(M-N) Relative proportions of 'attack-active' neurons excited (red), inhibited (blue), or unaffected (gray) while contacting an object $(\mathrm{M})$ or a male $(\mathrm{N})$ (left), Z-score of firing rate (middle) and AUC per second (right) of the 'attack-active' neurons excited by sniffing an object $(\mathrm{M})$ or a male $(\mathrm{N})$ for the 'attack-active' neurons.

$(\mathrm{O}-\mathrm{R}) \mathrm{Z}$-score of the firing rate of the 'object sniff-active' $(\mathrm{O})$ or 'male sniff-active' $(\mathrm{Q})$ neurons excited by sniffing an object (O) or a male (Q) (left). Relative proportions of 'object sniff-active' (P) or 'male sniff-active' (R) neurons excited (red), inhibited (blue), or unaffected (gray) by aggression (left), AUC per second before, during, and after an attack for 'object sniff-active' (P) or 'male sniff-active' (R) neurons (right).

(S) Relative proportions of pSI neurons excited during three different behavioral activities. 
381

382

383

384

385

386

387

388

389

390

391

392

393

394

395

396

397

398

399

400

401

402

403

404

405

406

407

408

409

410

411

412

413

414

415

416

(T) The proportion of neurons excited in three distinct behaviors among pSI 'attack-active' neurons.

Data are presented as the mean \pm SEM. See also Figure S1.

\section{Figure 2. Graded $\mathrm{Ca}^{2+}$ Responses in pSI $^{\text {Thy1 }}$ Neurons under the Different Aggressive States}

(A) Setup for fiber photometric recording in $\mathrm{pSI}^{\text {Thy1 }}$ neurons during social behaviors.

(B) Representative GCaMP6m signals during various social behaviors.

(C, D) Distribution of episodes of behavior (upper), heatmaps of GCaMP6m $\Delta F / F$ signals from $\mathrm{pSI}^{\text {Thy1 }}$ neurons, time windows of $\mathrm{pSI}^{\text {Thy1 }}$ neuronal activation, and $\Delta F / F$ of the EYFP and GCaMP6m signals (lower) before, during, and after a sniff without an attack (C) and a sniff preceding an attack (D).

(E) Peak $\Delta F / F$ of GCaMP6m and EYFP signals during a sniff with and without a subsequent attack.

(F) Peak $\triangle F / F$ of GCaMP6m signals before, during, and after a sniff with or without a subsequent attack.

$(\mathrm{G}, \mathrm{H})$ Sample decoding accuracy $(\mathrm{G})$ and averaged sample decoding accuracy $(\mathrm{H})$ of $\mathrm{pSI}^{\text {Thy } 1}$ neuronal activity in the sniff/sniff (attack) trials under shuffled (black) and recording (red) conditions.

(I-K) Distribution of episodes of behavior (upper), heatmaps of GCaMP6m $\Delta F / F$ signals from $\mathrm{pSI}^{\text {Thy1 }}$ neurons (middle), and $\Delta F / F$ of GCaMP6m signals (lower) before, during, and after a rattle without an attack (I), a rattle preceding an attack (J), and threat behavior $(\mathrm{K})$.

(L) Peak $\Delta F / F$ of GCaMP6m signals before, during, and after a rattle without a subsequent attack, a rattle preceding an attack, and a threat behavior.

$(\mathrm{M}, \mathrm{N})$ Decoding accuracy $(\mathrm{M})$ and averaged sample decoding accuracy $(\mathrm{N})$ of the $\mathrm{pSI}^{\text {Thy1 }}$ neuronal activity in rattle/rattle (attack) trials.

(O) Peak $\Delta F / F$ (upper) and AUC/s (lower) of GCaMP6m signals during non-aggressive states, aggressive states, and aggressive attacks. ' $\#$ ' and ' $\&$ ' above each bar indicate that the value during each behavior period was $(P<0.05)$ and wasn't $(P>0.05)$ significantly changed compared with the EYFP control group.

$(\mathrm{P}, \mathrm{Q})$ Decoding accuracy $(\mathrm{P})$ and averaged sample decoding accuracy $(\mathrm{Q})$ of the $\mathrm{pSI}^{\text {Thy1 }}$ neuronal activity in three social behavior trials (sniff $v s$ sniff (attack) $v s$ attack).

Data are presented as the mean \pm SEM. See also Figures S2, S3.

\section{Figure 3. Graded $\mathrm{Ca}^{2+}$ Responses in $\mathrm{pSI}^{\text {Thy1 }}$ Neurons under Diverse Aggressive Behaviors}

(A) Setup for fiber photometric recording of $\mathrm{pSI}^{\text {Thy1 }}$ neuronal activity during diverse aggressive behaviors. 
(B-G) Distribution of attack episodes (upper) and heatmap of GCaMP6m $\Delta F / F$ signals from pSI neurons (lower) in male-female (B) or defensive aggression (E). Time window of the $\mathrm{pSI}^{\text {Thy } 1}$ neuronal activation (upper) and $\triangle F / F$ of GCaMP6m signals (lower) before, during, and after a male-female $(\mathrm{C})$ or a defensive attack $(\mathrm{F})$. Peak $\Delta F / F$ of GCaMP6m signals before, during, and after male-male and male-female attacks (D), or male-male offensive and defensive attacks (G). $(\mathrm{H}-\mathrm{V})$ From top to bottom: distribution of episodes of behavior, heatmaps of GCaMP6m $\Delta F / F$ signals from pSI neurons, the time window of $\mathrm{pSI}^{\text {Thy1 }}$ neuronal activation, and $\Delta F / F$ of GCaMP6m signals of approach without an attack (H), approach preceding attack (I), and attack $(\mathrm{J})$ in predatory aggression, without attack $(\mathrm{M})$, approach preceding attack $(\mathrm{N})$, and attack $(\mathrm{O})$ in pup-directed aggression, or without attack $(\mathrm{R})$, sniff preceding attack $(\mathrm{S})$, and attack $(\mathrm{T})$ in female-male aggression. Decoding accuracy of pSI neuronal $\mathrm{Ca}^{2+}$ signals in the approach/sniff, approach/sniff (attack), and attack trials (left); averaged sample decoding accuracy of pSI neuronal activity under recording conditions (right) for predatory attack (K), pup-directed attacks (P), or female-male attacks (U). Peak $\Delta F / F$ of GCaMP6m signals of a male-male attack and a predatory attack (L), male-male attacks and pup-directed attacks (Q), or male-male and femalemale attacks $(\mathrm{V})$.

(W) Peak $\triangle F / F$ (upper) and AUC/s (lower) of GCaMP6m signals during diverse aggressive behaviors.

\section{Data are presented as the mean \pm SEM. See also Figures S3, S4.}

\section{Figure 4. Activation of pSI $^{\text {Thy1 }}$ or pSI $^{-P A G}$ Neurons Promotes Inter-male Aggression and} Autonomic Arousal

(A) Experimental design and schematic of the viral injection strategy.

(B) Overlay of DIO-hM3Dq-mCherry expression in pSI.

(C) Percentage of animals showing aggressive or mating behaviors (left), latency, duration, and events of attacks before (pre-) and after injection with saline or CNO in the control and hM3Dq groups (right).

(D) Representative images of retrograde AAV-retro-EGFP infection (green) in the PAG (left) and pSI (right) (scale bars, $100 \mu \mathrm{m}$ ). Aq, aqueduct; DRL, dorsal raphe nucleus, lateral part.

(E) Proportion of retrogradely-labeled $\mathrm{SI}^{-\mathrm{PAG}}$ neurons distributed in the SI.

(F) Strategy for photoactivation of $\mathrm{pSI}^{-\mathrm{PAG}}$ neurons in male mice.

(G) The behavioral paradigm of aggression test.

(H) Distribution of attack episodes during photostimulation.

(I) Percentage of trials, latency, duration, and events of attacks in the ChR2 and control groups in pre-laser, laser, and post-laser phases.

(J) Schematic of assessment of autonomic arousal in head-fixed mice with photostimulation of 
$453 \quad \mathrm{pSI}^{-\mathrm{PAG}}$ neurons.

454 (K) Schematic for eye and pupil size measurements.

455 (L) Representative images of the computer-detected pupil (red circle) and eye (green outline)

456 before, during, and after photostimulation.

457 (M, N) Left, changes of normalized pupil size $(\mathrm{M})$ and eye size $(\mathrm{N})$ in the laser and sham 458 stimulation groups. Right, averaged pupil size $(\mathrm{M})$ and eye size $(\mathrm{N})$ before, during, and after 459 photostimulation.

460 (O-Q) Normalized breathing rate $(\mathrm{O})$, normalized heart rate $(\mathrm{P})$, and duration of body trembling 461 (Q) before, during, and after photostimulation.

462 (R) Cartoon of the increased aggressive arousal during the activation of $\mathrm{pSI}^{-\mathrm{PAG}}$ neurons. Data are presented as the mean \pm SEM. See also Figures S5, S6, S7, and Movies S1, S2.

Figure 5. Activation of pSI-PAG Neurons Promotes Diverse Aggressive Behaviors neurons under various conditions. aggression $(\mathrm{H})$ with photostimulation of $\mathrm{pSI}^{-\mathrm{PAG}}$ neurons. Right, distribution of attack episodes during photostimulation $(\mathrm{B}, \mathrm{F}, \mathrm{H})$. Percentage of trials, latency, duration, and events of induced female (C), pup-directed (E, no duration and events), object-directed (G), and defensive aggression (I) by photostimulation of $\mathrm{pSI}^{-\mathrm{PAG}}$ neurons.

473 (J) Probability of light-induced aggression in thirteen aggression paradigms. different types of aggression. neurons at different stimulation intensities.

(C) Distribution of attack episodes during photoactivation of $\mathrm{pSI}^{-\mathrm{PAG}}$ neurons at 13 graded stimulation intensities. intensities of photostimulation, before (gray) and during (blue) laser stimulation. Lines are nonlinear fits (pooled across all mice and binned light intensities). neurons at different stimulation intensities. 
489 (F, G) Nonlinear regression of the probabilities (F) and latencies (G) of attacks for the five types 490 of induced aggression with different photostimulation intensities before and during laser 491 stimulation.

492 (H) Probabilities of trials showing attack (left) and latency to attack onset (right) of the five types 493 of induced aggression during laser stimulation with a lower intensity $(0.1 \mathrm{~mW})$.

494 (I) Threshold model for the relationship between the activation level of $\mathrm{pSI}^{-\mathrm{PAG}}$ neurons and 495 evoked attacks for diverse aggressive behaviors.

496 Data are presented as the mean \pm SEM. See also Figure S12.

Figure 7. Inactivation of pSI ${ }^{\text {Thy }}{ }^{1}$ Neurons Interrupts Diverse Aggressive Behaviors but not Mating

(A) Experimental design and viral injection strategy for the expression of hM4Di-mCherry in $\mathrm{pSI}^{\text {Thy1 }}$ neurons in male Thy1-Cre mice.

(B) Schematic of virus injection and a representative histological image showing the expression of hM4Di-mCherry (red) in $\mathrm{pSI}^{\text {Thy1 }}$ neurons (scale bar, $100 \mu \mathrm{m}$ ).

505

(C) Latency (left), duration (middle), and events (right) of attack before and after injection of saline or CNO in the control and hM4Di groups.

(D) Mating behavioral paradigm.

508 injection of saline or CNO in Thy1-Cre mice.

509 (F) Upper, schematic of bilateral injection of DIO-GtACR1-GFP virus into the pSI in male Thy1-

510 Cre mice. Lower, the co-localization ratio of GFP expression with CaMKII $\alpha$ in the pSI.

511 (G-I) Behavioral paradigms (left) and example raster plots (right) of optogenetic inhibition of $512 \mathrm{pSI}^{\text {Thy1 }}$ neurons on offensive inter-male $(\mathrm{G})$, pup-directed $(\mathrm{H})$, and predatory aggression $(\mathrm{I})$.

513 (J-L) Distribution of attack episodes interrupted by optogenetic inhibition of $\mathrm{pSI}^{\text {Thy1 }}$ neurons in 514 inter-male $(\mathrm{J})$, pup-directed $(\mathrm{K})$, and predatory aggression $(\mathrm{L})$.

515 (M) Attack duration by optogenetic inhibition of aggressive behaviors.

516 (N) Percentage of attack trials interrupted within $3 \mathrm{~s}$ during the laser phase by optogenetic 517 inhibition in aggressive behaviors.

518 Data are presented as the mean \pm SEM. See also Figures S13, S14, and Movie S5. 
bioRxiv preprint doi: https://doi.org/10.1101/2020.04.22.047670; this version posted February 19, 2021. The copyright holder for this preprint (which was not certified by peer review) is the author/funder, who has granted bioRxiv a license to display the preprint in perpetuity. It is made available under aCC-BY-NC-ND 4.0 International license.

Figures 1-7

\section{Figure 1}

A

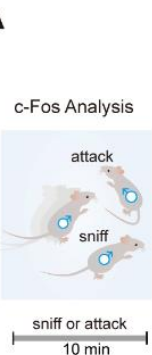

B

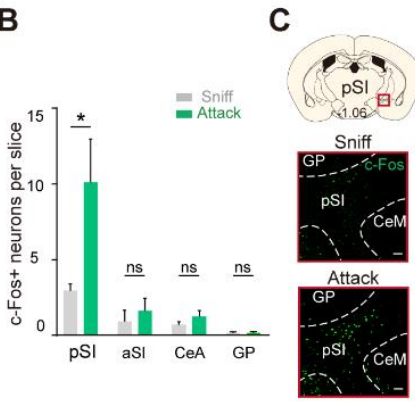

H

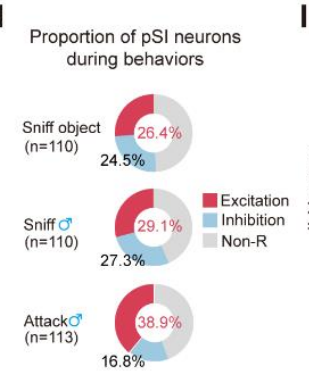

M

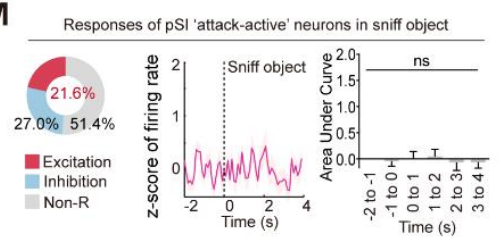

0

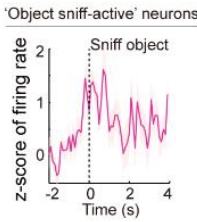

I

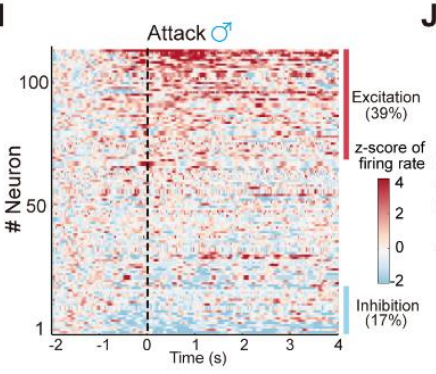

N

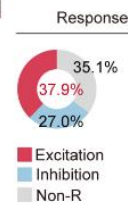

P

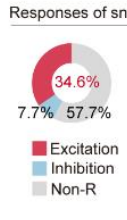

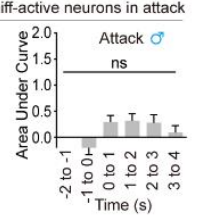

Q

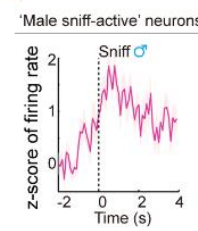

R
D

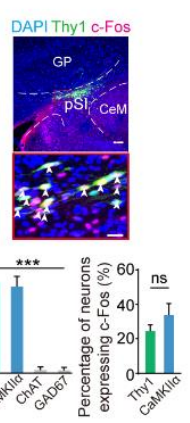

J

All Neurons ( $n=113)$

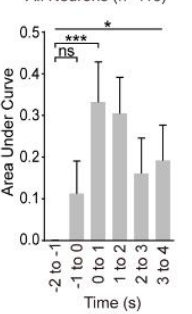

F

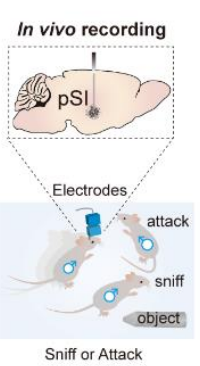

G

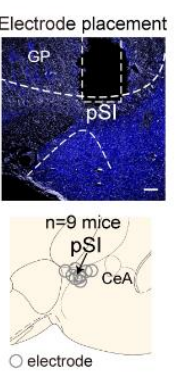

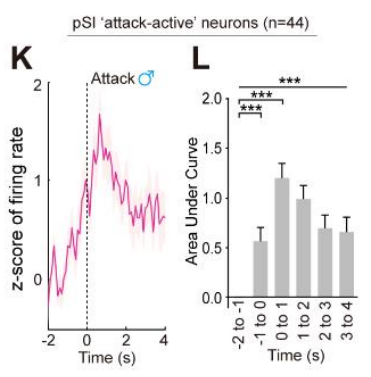

$\mathrm{S}$

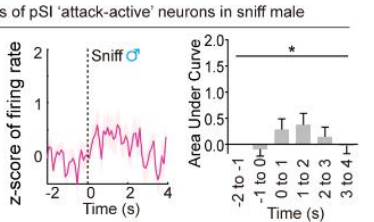

Summary of $64 \mathrm{pSI}$ excited neurons by three conditions Attack $\sigma^{7}$

T Proportion of neurons activated in three behaviors among pSI 'attack-active' neurons

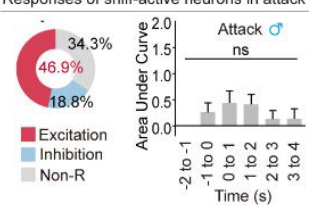


bioRxiv preprint doi: https://doi.org/10.1101/2020.04.22.047670; this version posted February 19,2021. The copyright holder for this preprint (which was not certified by peer review) is the author/funder, who has granted bioRxiv a license to display the preprint in perpetuity. It is made available under aCC-BY-NC-ND 4.0 International license.

Figure 2

A

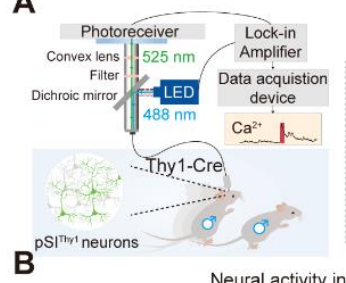

Neural activity in sample events

IAttack i Threat isniffattack) i Rattie(attack) i Rattle is Sniff

Home cage

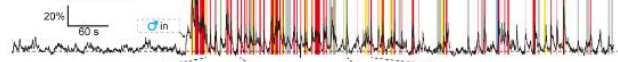

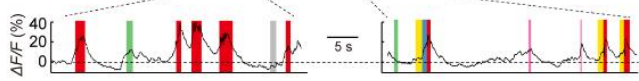

C

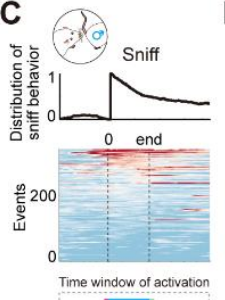

Time window of activation
-Pre - Sniff - Post

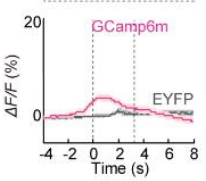

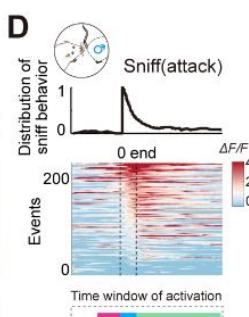

Trime window of activation

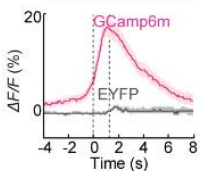

E

-EYFP
-GCamp @ 60 *夫夫

嵌 40

$\checkmark 20+4$

$\mathbf{F}$

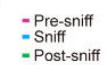

Postsn

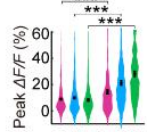

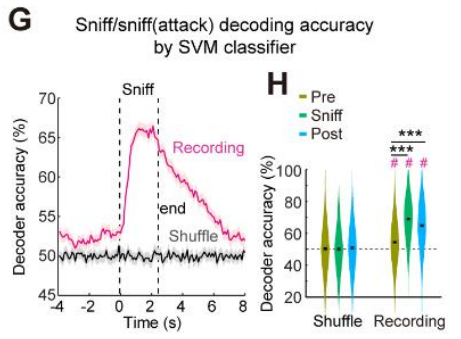
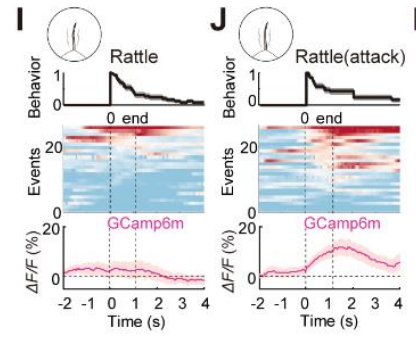

$\mathrm{K}, \mathrm{s}$

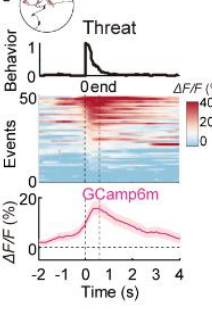

L

- Pre-behavior - Behavior - Post-behavior

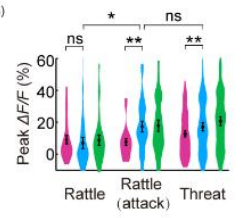

M Rattle/rattle(attack) decoding accuracy
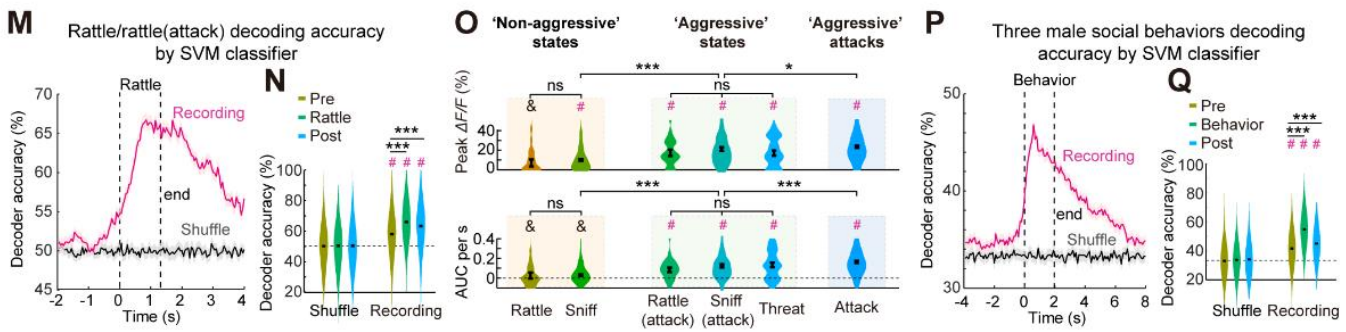
bioRxiv preprint doi: https://doi.org/10.1101/2020.04.22.047670; this version posted February 19,2021. The copyright holder for this preprint (which was not certified by peer review) is the author/funder, who has granted bioRxiv a license to display the preprint in perpetuity. It is made available under aCC-BY-NC-ND 4.0 International license.

\section{Figure 3}

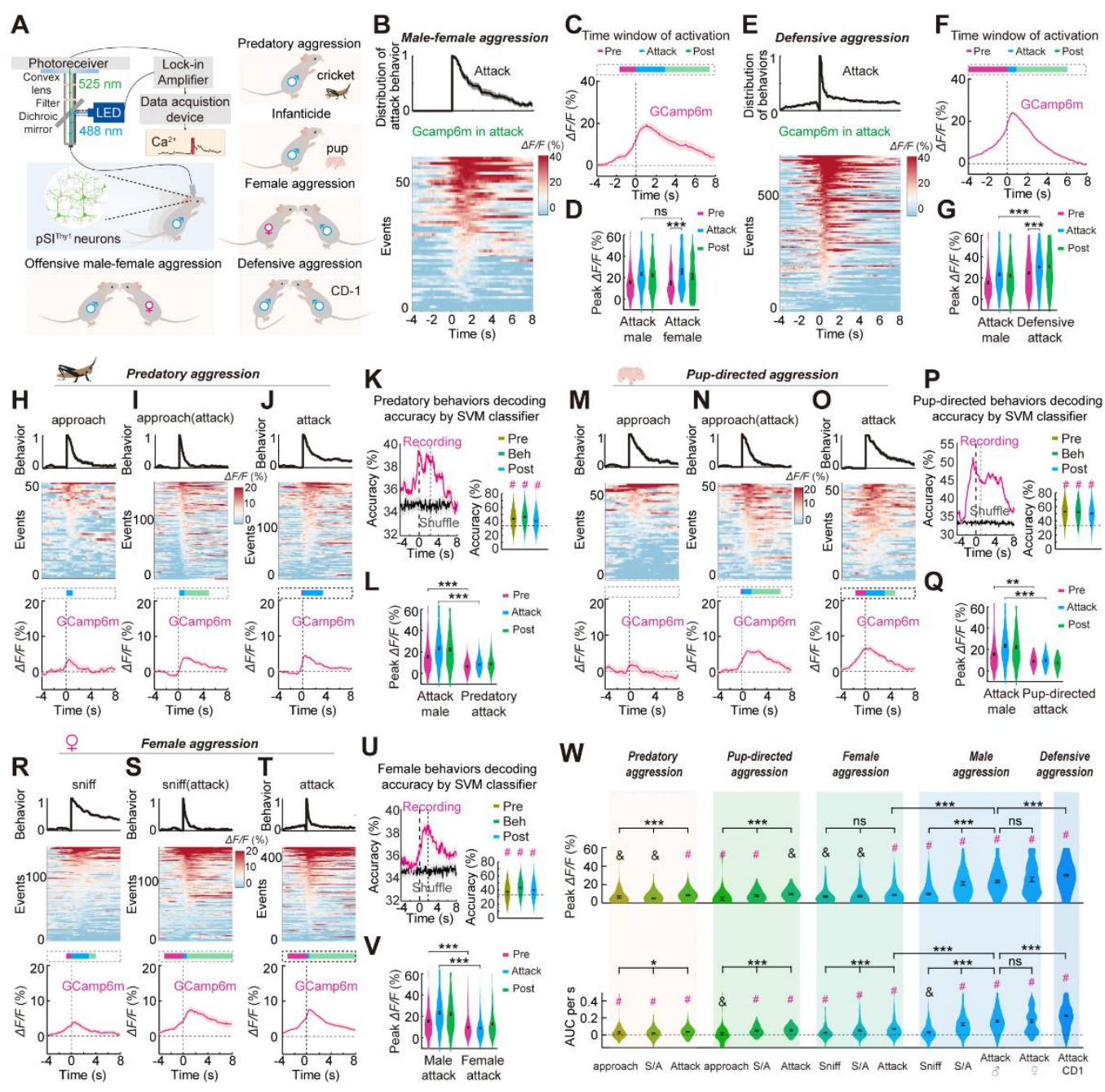


bioRxiv preprint doi: https://doi.org/10.1101/2020.04.22.047670; this version posted February 19, 2021. The copyright holder for this preprint (which was not certified by peer review) is the author/funder, who has granted bioRxiv a license to display the preprint in perpetuity. It is made available under aCC-BY-NC-ND 4.0 International license.

\section{Figure 4}
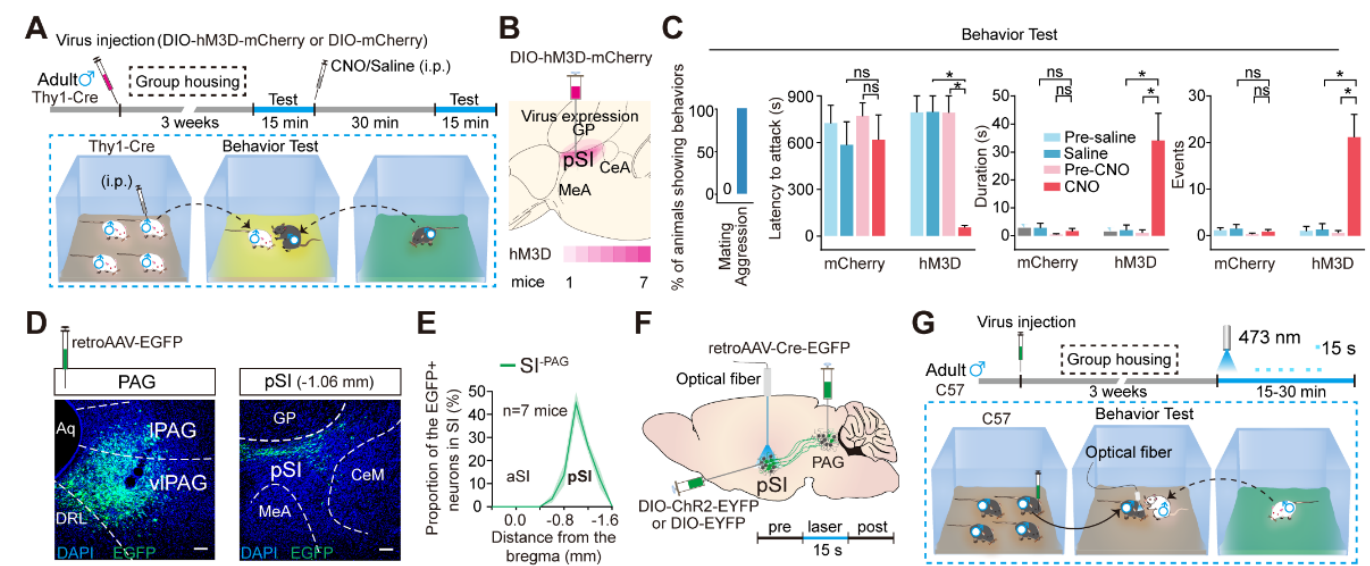

E

F
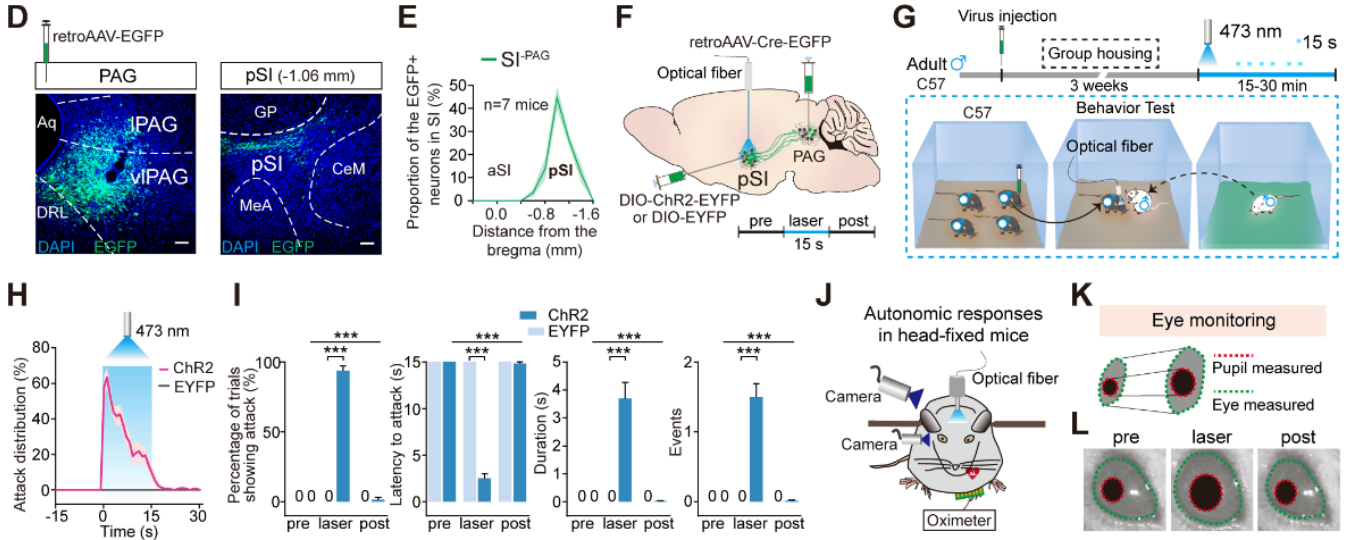

I

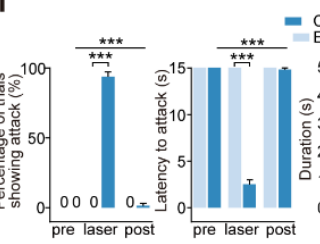

$=$ ChR2

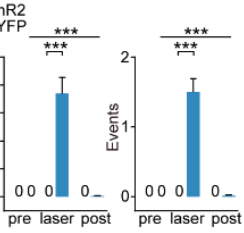

J

Autonomic responses $\mathbf{K}$ Autonomic responses
in head-fixed mice

K
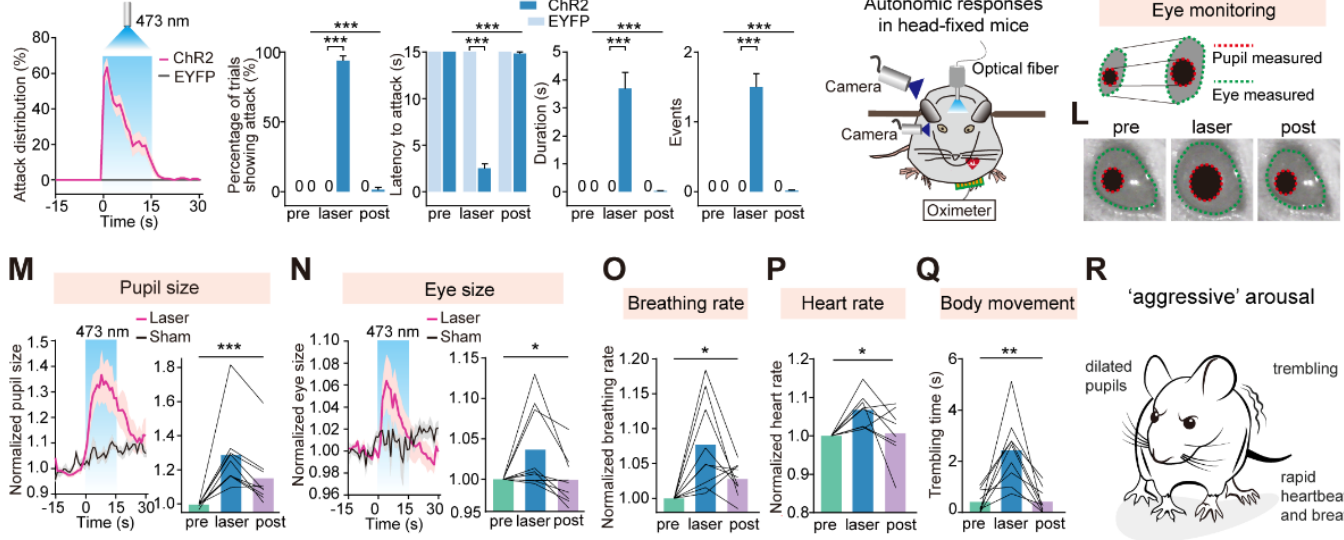

$\mathbf{N}$

Breathing rate

Heart rate

Q Body movement

$\mathbf{R}$
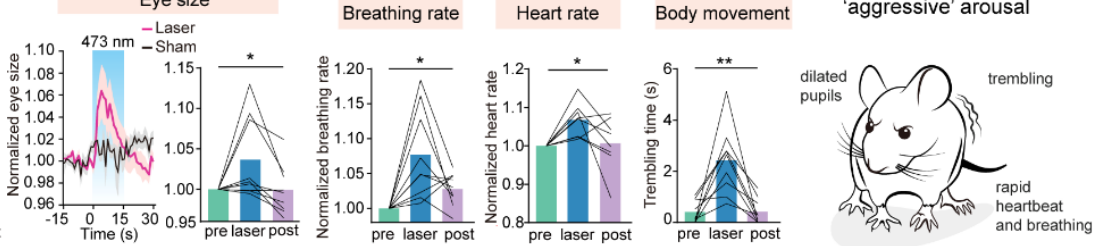
bioRxiv preprint doi: https://doi.org/10.1101/2020.04.22.047670; this version posted February 19, 2021. The copyright holder for this preprint (which was not certified by peer review) is the author/funder, who has granted bioRxiv a license to display the preprint in perpetuity. It is made available under aCC-BY-NC-ND 4.0 International license.

\section{Figure 5}

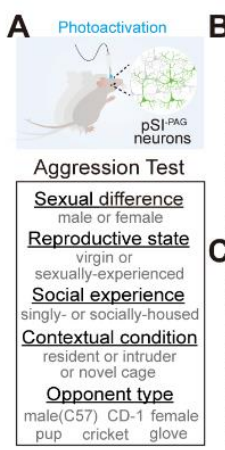

F

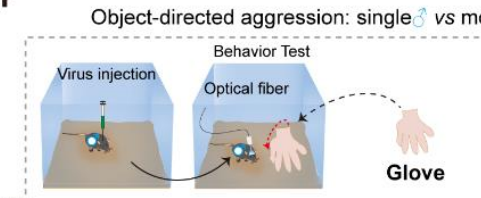

G
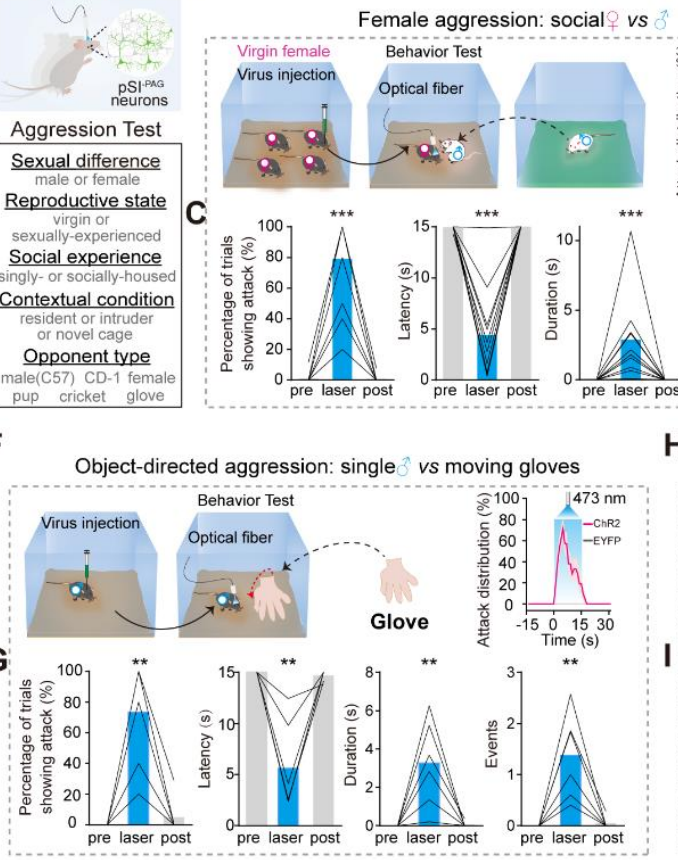

D
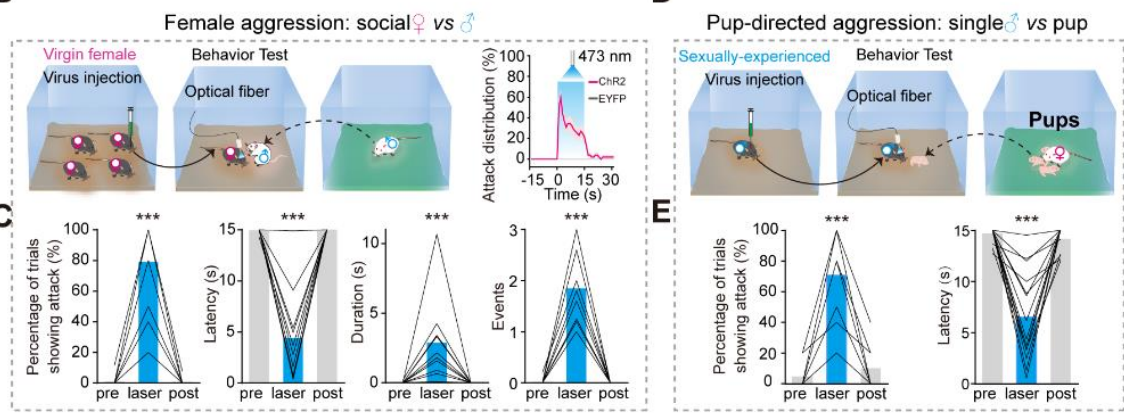

H

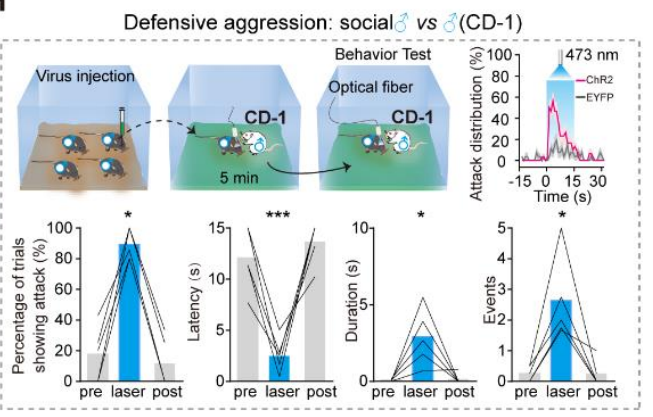

$\mathrm{ns}$
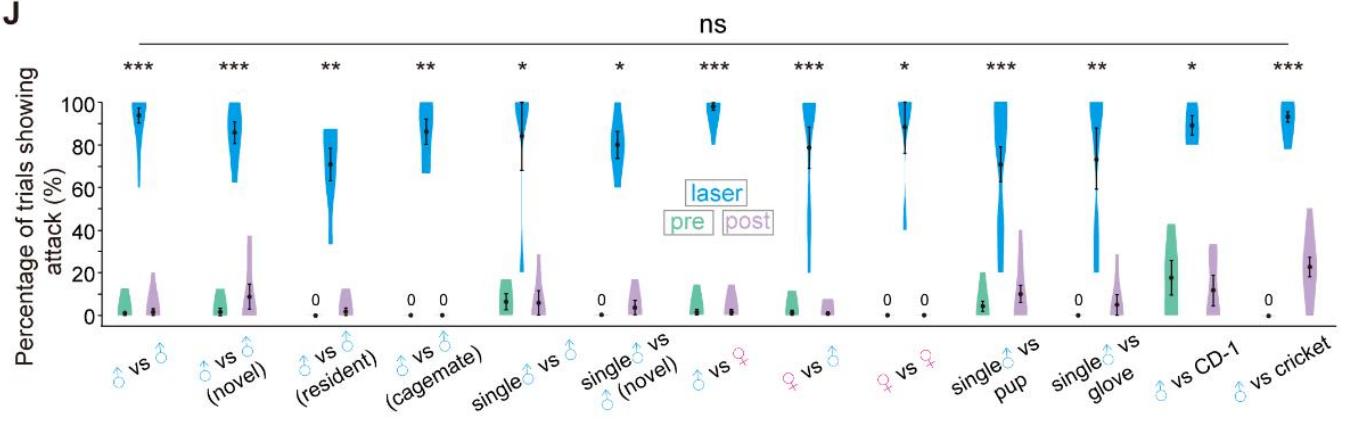
bioRxiv preprint doi: https://doi. org/10.1101/2020.04.22.047670; this version posted February 19, 2021. The copyright holder for this preprint (which was not certified by peer review) is the author/funder, who has granted bioRxiv a license to display the preprint in perpetuity. It is made available under aCC-BY-NC-ND 4.0 International license.

Figure 6
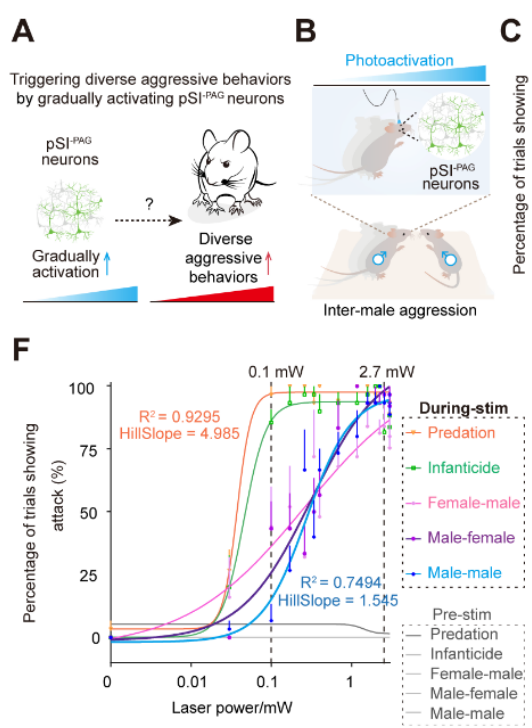

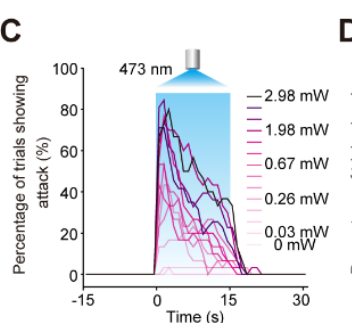

G

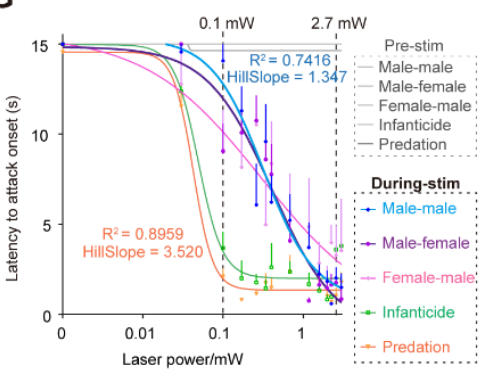

E

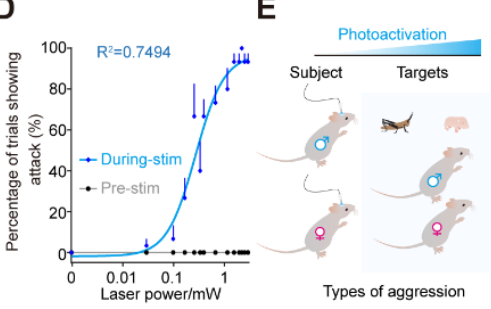

H

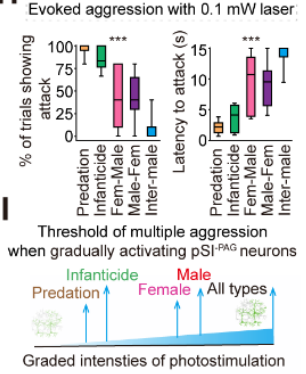


bioRxiv preprint doi: https://doi.org/10.1101/2020.04.22.047670; this version posted February 19, 2021. The copyright holder for this preprint (which was not certified by peer review) is the author/funder, who has granted bioRxiv a license to display the preprint in perpetuity. It is made available under aCC-BY-NC-ND 4.0 International license.

Figure 7

A

B
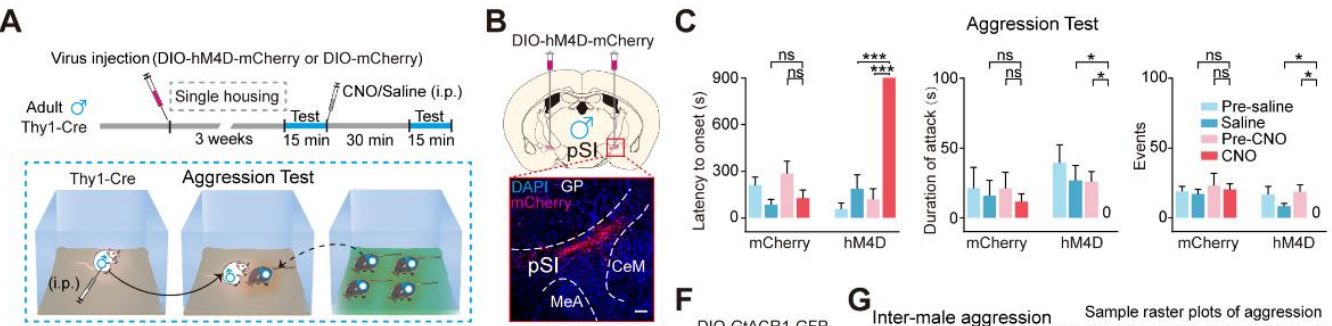

D

E

$F_{\text {DIO-GAACR1-GFP }}$

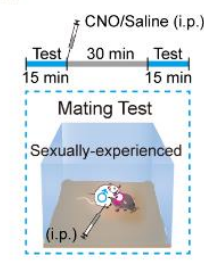

Mating Test

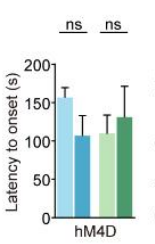

ns ns

ns ns

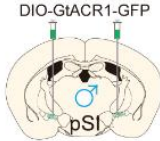

G
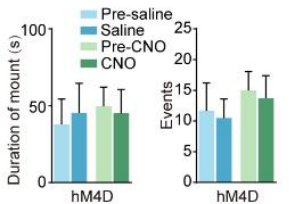

Thy1-Cre

‡

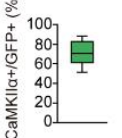

Sample raster plots of aggression

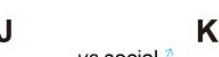

K
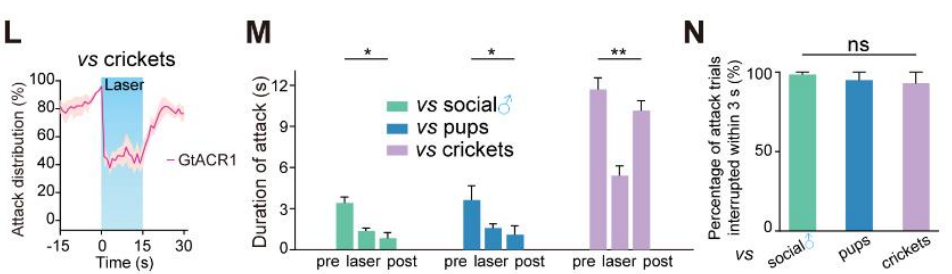
520 Supplemental Information includes STAR+METHODS, fourteen figures, two tables, and

521 five movies.

522

523 STAR $\star$ METHODS

524 Detailed methods are provided in the online version of this paper and include the following:

525 •CONTACT FOR REAGENT AND RESOURCE SHARING

526 •EXPERIMENTAL MODEL AND SUBJECT DETAILS

$527 \quad$ oAnimals

528 -METHOD DETAILS

$529 \quad$ Viral injection and stereotaxic surgeries

530 OAnterograde and retrograde viral tracing

531 oBehavior measurements and video analysis

532 OAutonomic responses

$533 \circ$ Anxiety and fear response measurements

534 oFeeding behavior measurements

535 OHM4Di-mediated neural silencing and hM3Dq-mediated neural activation

536 OChR2-mediated neural activation

537 ChR2-mediated neural activation before and after acute social defeat

538 Optogenetic inhibition of neural activity

539 oFiber photometry

540 ODecoder analysis by the support vector machine (SVM) algorithm

541 oSingle-unit recording and data analysis

542 OIn vitro electrophysiology

543 OHistology 
•QUANTIFICATION AND STASTISTICAL ANALYSIS

-KEY RESOURCES TABLE

Further information and requests for resources and reagents should be directed to and will be

fulfilled by the Contact, Yan-qin Yu (yanqinyu@zju.edu.cn).

KEY RESOURCES TABLE

\begin{tabular}{|c|c|c|}
\hline REAGENT or RESOURCE & SOURCE & IDENTIFIER \\
\hline \multicolumn{3}{|l|}{ Antibodies } \\
\hline Mouse monoclonal anti-GAD67 & Millipore & $\begin{array}{l}\text { Cat\# MAB5406; RRID: } \\
\text { AB_2278725 }\end{array}$ \\
\hline Rabbit polyclonal anti-ChAT & Millipore & $\begin{array}{l}\text { Cat\# AB143; RRID: } \\
\text { AB_2079760 }\end{array}$ \\
\hline Rabbit polyclonal anti-GAD65/67 & Abcam & $\begin{array}{l}\text { Cat\# ab11070; RRID: } \\
\text { AB_297722 }\end{array}$ \\
\hline Rabbit polyclonal anti-c-Fos & Millipore & $\begin{array}{l}\text { Cat\# PC38; RRID: } \\
\text { AB_2106755 }\end{array}$ \\
\hline Rabbit polyclonal anti-CaMKII $\alpha$ & Epitomics & Cat\# 2048-1; RRID: \\
\hline $\begin{array}{l}\text { Donkey anti-Rabbit IgG }(\mathrm{H}+\mathrm{L}) \\
\text { Highly Cross-Adsorbed Secondary } \\
\text { Antibody, Alexa Fluor } 488\end{array}$ & Invitrogen & $\begin{array}{l}\text { Cat\# A21206; RRID: } \\
\text { AB_2535792 }\end{array}$ \\
\hline $\begin{array}{l}\text { Cy3-AffiniPure Goat Anti-Rabbit } \\
\text { IgG }(\mathrm{H}+\mathrm{L}) \text { antibody }\end{array}$ & Jackson & $\begin{array}{l}\text { Cat\# 111-165-144; RRID: } \\
\text { AB_2338006 }\end{array}$ \\
\hline $\begin{array}{l}\text { Goat monoclonal anti-rabbit IgG } \\
\text { secondary antibody }\end{array}$ & Millipore & N/A \\
\hline $\begin{array}{l}\text { Donkey Anti-Rabbit IgG }(\mathrm{H}+\mathrm{L}) \\
\text { Polyclonal Antibody, Alexa Fluor } \\
647 \text { Conjugated }\end{array}$ & Invitrogen & $\begin{array}{l}\text { Cat\# A31573; RRID: } \\
\underline{\text { AB_2536183 }}\end{array}$ \\
\hline \multicolumn{3}{|l|}{ Bacterial and Virus Strains } \\
\hline $\begin{array}{l}\text { pAAV-CaMKII } \alpha-C h R 2(H 134 R)- \\
\text { mCherry }\end{array}$ & $\begin{array}{l}\text { Shanghai SunBio } \\
\text { Biomedical } \\
\text { technology Co. }\end{array}$ & Cat\# PMT28 \\
\hline pAAV-CaMKII $\alpha$-mCherry & $\begin{array}{l}\text { Shanghai SunBio } \\
\text { Biomedical } \\
\text { technology Co. }\end{array}$ & Cat\# PMT191 \\
\hline $\begin{array}{l}\text { pAAV-EF1 } \alpha \text {-DIO-hChR2(H134R)- } \\
\text { EYFP }\end{array}$ & $\begin{array}{l}\text { Shanghai SunBio } \\
\text { Biomedical }\end{array}$ & Cat\# MT65 \\
\hline
\end{tabular}




\begin{tabular}{|c|c|c|}
\hline & technology Co. & \\
\hline pAAV-EF1 $\alpha$-DIO-EYFP & $\begin{array}{l}\text { Shanghai SunBio } \\
\text { Biomedical } \\
\text { technology Co. }\end{array}$ & Cat\# PMT150 \\
\hline $\begin{array}{l}\text { AAV9-hSyn-DIO-hM4D(Gi)- } \\
\text { mCherry }\end{array}$ & $\begin{array}{l}\text { Shanghai Taitool } \\
\text { Bioscience Co. }\end{array}$ & Cat\# S0193-9 \\
\hline $\begin{array}{l}\text { AAV8-hSyn-DIO-hM3D(Gq)- } \\
\text { mCherry }\end{array}$ & $\begin{array}{l}\text { Shanghai Taitool } \\
\text { Bioscience Co. }\end{array}$ & Cat\# S0192-9 \\
\hline $\begin{array}{l}\text { AAV9-EF1 } \alpha \text {-DIO-GtACR1-GFP- } \\
\text { WPRE }\end{array}$ & $\begin{array}{l}\text { Shanghai Taitool } \\
\text { Bioscience Co. }\end{array}$ & Cat\# S0575-9 \\
\hline AAV2/2Retro-hSyn-retro-EGFP & $\begin{array}{l}\text { Shanghai Talitol } \\
\text { Bioscience Co. }\end{array}$ & Cat\# S0237-2R \\
\hline AAV2/2Retro-CMV_Gl-Cre-EGFP & $\begin{array}{l}\text { Shanghai Taitool } \\
\text { Bioscience Co. }\end{array}$ & Cat\# S0231-2R \\
\hline $\begin{array}{l}\text { AAV2/9-hSyn-DIO-GCaMP6m- } \\
\text { WPRE }\end{array}$ & $\begin{array}{l}\text { Shanghai Taitool } \\
\text { Bioscience Co. }\end{array}$ & Cat\# S0277-9 \\
\hline $\begin{array}{l}\text { Rabies viruses SAD-OG-mCherry } \\
\text { (EnvA) }\end{array}$ & BrainVTA, Wuhan & Cat\# RV-306 \\
\hline AAV-CAG-DIO-RG & BrainVTA, Wuhan & Cat\# AAV-902 \\
\hline AAV-CAG-DIO-TVA-EGFP & BrainVTA, Wuhan & Cat\# AAV-903 \\
\hline AAV1-CMV-Cre & BrainVTA, Wuhan & N/A \\
\hline AAV2-EF1 $\alpha$-DIO-mCherry & BrainVTA, Wuhan & Cat\# PT-0013 \\
\hline $\begin{array}{l}\text { Rabies viruses SAD-OG-mCherry } \\
\text { (EnvA) }\end{array}$ & BrainVTA, Wuhan & N/A \\
\hline AAV-DIO-G & BrainVTA, Wuhan & Cat\# AAV-902 \\
\hline AAV-DIO-TVA-EGFP & BrainVTA, Wuhan & Cat\# AAV-903 \\
\hline $\begin{array}{l}\text { AAV-FLEx-EGFP-2A- } \\
\text { Synaptophysin-mRuby }\end{array}$ & $\begin{array}{l}\text { Shanghai Taitool } \\
\text { Bioscience Co. }\end{array}$ & Cat\# S0250-9 \\
\hline $\begin{array}{l}\text { AAV2/2Retro-CAG-FLEX-Flpo - } \\
\text { WPRE }\end{array}$ & $\begin{array}{l}\text { Shanghai Taitool } \\
\text { Bioscience Co. }\end{array}$ & Cat\# S0273-2R \\
\hline $\begin{array}{l}\text { AAV2/9-hEF1a-fFIO-hChR2 } \\
\text { (H134R)-EYFP }\end{array}$ & $\begin{array}{l}\text { Shanghai Taitool } \\
\text { Bioscience Co. }\end{array}$ & Cat\# S0129-9 \\
\hline \multicolumn{3}{|c|}{ Chemicals, Peptides, and Recombinant Proteins } \\
\hline Clozapine N-oxide (CNO) & Sigma-Aldrich & Cat\# C0832 \\
\hline DAPI & Sigma-Aldrich & Cat\# D9542 \\
\hline CTB555 & Life Technologies & Cat\# C34776 \\
\hline \multicolumn{3}{|c|}{ Experimental Models: Organisms/Strains } \\
\hline C57BL/6N mice & $\begin{array}{l}\text { Slackom company, } \\
\text { Shanghai }\end{array}$ & N/A \\
\hline
\end{tabular}




\begin{tabular}{|c|c|c|}
\hline BALB/c mice & $\begin{array}{l}\text { Slackom company, } \\
\text { Shanghai }\end{array}$ & N/A \\
\hline FVB/N mice & $\begin{array}{l}\text { Slackom company, } \\
\text { Shanghai }\end{array}$ & N/A \\
\hline Gad1-ires-GFP mice & $\begin{array}{l}\text { The Jackson } \\
\text { Laboratory }\end{array}$ & Stock No: 007673 \\
\hline Thy1-Cre mice (FVB/N) & $\begin{array}{l}\text { The Jackson } \\
\text { Laboratory }\end{array}$ & Stock No: 006143 \\
\hline CD-1 male mice (ICR) & $\begin{array}{l}\text { Vital Alver company, } \\
\text { Beijing }\end{array}$ & N/A \\
\hline Ai14 mice & $\begin{array}{l}\text { The Jackson } \\
\text { Laboratory }\end{array}$ & Stock No: 007908 \\
\hline \multicolumn{3}{|l|}{ Software and Algorithms } \\
\hline MATLAB & MathWorks & $\begin{array}{l}\text { https://www.mathworks.com/pr } \\
\text { oducts.html; } \\
\text { RRID:SCR_001622 }\end{array}$ \\
\hline GraphPad Prism 6 & GraphPad Software & $\begin{array}{l}\text { https://www.graphpad.com/scie } \\
\text { ntificsoftware/prism/; RRID: } \\
\text { SCR_002798 }\end{array}$ \\
\hline ImageJ & NIH & $\begin{array}{l}\text { https://imagej.nih.gov/ij/index. } \\
\text { html; RRID:SCR_003070 }\end{array}$ \\
\hline $\begin{array}{l}\text { OmniPlex Neural Recording Data } \\
\text { Acquisition Systems }\end{array}$ & Plexon & $\begin{array}{l}\text { https://plexon.com/products/o } \\
\text { mniplex-software/; } \\
\text { RRID:SCR_014803 }\end{array}$ \\
\hline Offline Sorter & Plexon & $\begin{array}{l}\text { www.plexon.com/products/offl } \\
\text { ine-sorter; RRID:SCR_000012 }\end{array}$ \\
\hline NeuroExplorer & Plexon & $\begin{array}{l}\text { https://plexon.com/products/ne } \\
\text { uroexplorer/; } \\
\text { RRID:SCR_001818 }\end{array}$ \\
\hline ANY-maze & Stoelting & $\begin{array}{l}\text { http://www.anymaze.co.uk/; } \\
\text { RRID:SCR_014289 }\end{array}$ \\
\hline 473nm LED & Newton, Hangzhou & http://www.newdoon.com/cn/ \\
\hline \multirow[t]{2}{*}{ Implantable Optical Fibers } & Newton, Hangzhou & http://www.newdoon.com/cn/ \\
\hline & Anlai, Ningbo & http://www.anilab.cn/ \\
\hline $\begin{array}{l}16 \text { tungsten microwires, } 35-\mathrm{um} \\
\text { diameter }\end{array}$ & California Wine, US & N/A \\
\hline Pulse oximeter & $\begin{array}{l}\text { Maxim Integrated } \\
\text { Products, USA }\end{array}$ & $\begin{array}{l}\text { MAX30100 } \\
\text { (https://www.maximintegrated. } \\
\text { com/en.html) }\end{array}$ \\
\hline Fiber photometry system & $\begin{array}{l}\text { ThinkerTech, } \\
\text { Nanjing }\end{array}$ & N/A \\
\hline $\begin{array}{l}\text { Behavioral Analysis Code, } \\
\text { MATLAB }\end{array}$ & This paper & N/A \\
\hline Decoder Analysis by the Support & The LIBSVM library & https://www.csie.ntu.edu.tw/ c \\
\hline
\end{tabular}


bioRxiv preprint doi: https://doi.org/10.1101/2020.04.22.047670; this version posted February 19, 2021. The copyright holder for this preprint (which was not certified by peer review) is the author/funder, who has granted bioRxiv a license to display the preprint in perpetuity. It is made available under aCC-BY-NC-ND 4.0 International license.

Vector Machine (SVM) Algorithm

jlin/libsvm

552 


\section{EXPERIMENTAL MODEL AND SUBJECT DETAILS}

554

555

556

557

558

559

560

561

562

563

564

565

566

567

568

569

570

571

572

573

574

575

576

\section{Animals}

Male GAD1 (GAD67)-GFP mice, male Ai14 mice, male CD-1 (ICR) mice, male FVB/N mice, Thy1-Cre (FVB/N), C57BL/6J, and BALB/c mice of both sexes were used. For behavior tests in wild type mice and functional manipulation using in vivo fiber photometry and in vivo multi-unit recording experiments, 8 - to 20-week-old mice and 1- to 3-day-old naive pups were used. Mice were housed at $22 \pm 1^{\circ} \mathrm{C}$ and $55 \pm 5 \%$ humidity with food and water ad libitum. Animal experiments were conducted in accordance with the Guidelines for the Care and Use of Laboratory Animals of Zhejiang University and approved by Zhejiang University.

\section{METHOD DETAILS}

\section{Viral Injection and Stereotaxic Surgeries}

AAV-CaMKII $\alpha$-hChR2 (H134R)-mCherry (AAV2/9, 7.57×10 12 genomic copies/ml), AAVCaMKII $\alpha$-mCherry (AAV2/9, 1.00×10 12 genomic copies/ml), AAV-EF1 $\alpha$-DIO-ChR2 (H134R)-

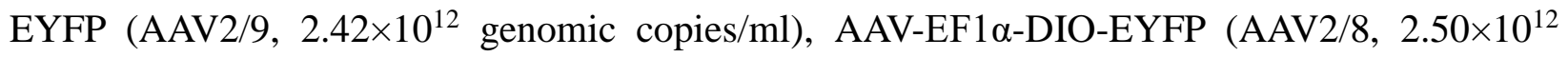
genomic copies/ml), AAV-hSyn-DIO-hM3Dq-mCherry (AAV2/9, 2.04×10 ${ }^{12}$ genomic copies/ml), and AAV-hSyn-DIO-hM4Di-mCherry (AAV2/8, 1.13×10 ${ }^{12}$ genomic copies/ml) were made by Shanghai SunBio Biomedical technology Co., Ltd. (Shanghai, China). AAV2/2Retro-CMV-CreEGFP $\left(1.75 \times 10^{13}\right.$ genomic copies/ml $)$, AAV2/2Retro-CMV-EGFP $\left(2.28 \times 10^{13}\right.$ genomic copies/ml), AAV2/9-CAG-DIO-GCaMP6m-WPRE (1.00×10 ${ }^{13}$ genomic copies/ml), and AAVEF1 $\alpha$-DIO-GtACR1-P2A-GFP-WPRE $\left(3.15 \times 10^{13}\right.$ genomic copies/ml) were made by Shanghai Taitool Bioscience Co., Ltd. (Shanghai, China). AAV1-CMV-Cre-WPRE-pA $\left(1.40 \times 10^{13}\right.$ genomic copies/ml), and AAV-EF1 $\alpha$-DIO-mCherry (AAV2/9, $1.00 \times 10^{13}$ genomic copies/ml) were provided by BrainVTA (Wuhan) Co., Ltd. (Wuhan, China). 
Mice were anesthetized with $1 \%$ sodium pentobarbital before stereotaxic injection of a

578 volume of 50-300 $\mathrm{nl}$ virus solution (depending on viral titer and expression strength). We injected $0.05-0.1 \mu \mathrm{l}$ of the virus into each location at $0.01 \mu \mathrm{l} / \mathrm{min}$, and the syringe was not removed until 5-10 min after the end of infusion to allow diffusion of the virus. A heating pad maintained core body temperature at $36^{\circ} \mathrm{C}$. The coordinates of viral injection sites included the PAG (AP, $-4.70 \mathrm{~mm}$; ML, $-0.8 \mathrm{~mm}$; DV, $-2.8 \mathrm{~mm})$ and the pSI (AP, $-0.90 \mathrm{~mm}$; ML, -2.3 $\mathrm{mm}$; DV, $-4.5 \mathrm{~mm})$. The coordinates of the cannula or optical fiber placement sites in the PAG and pSI were located 50-400 $\mu \mathrm{m}$ above the virus injection sites, and the coordinates of the optical fiber placement site in the BNST were AP, $-0.22 \mathrm{~mm}$; ML, $-0.9 \mathrm{~mm}$; DV, $-3.5 \mathrm{~mm}$, and the coordinates in the VMH were AP, $-1.70 \mathrm{~mm}$; ML, $-0.8 \mathrm{~mm}$; DV, $-5.5 \mathrm{~mm}$.

The pSI is a relatively little-studied region in the mouse brain, so we have better defined the pSI here (also see Figure S1), by comparing its relative coordinates and identifying the histological and chemical differences between the pSI and its surrounding structures (Grove, 1988a; Heimer et al., 1997). First, we registered the SI to the averaged template of the mouse brain atlas (Franklin and Paxinos, 2008) [we also referred to the Allen mouse brain atlas (http://atlas.brain-map.org/atlas) and https://bbp.epfl.ch/nexus/cell-atlas/)], and identified the pSI as the posterior part of the $\mathrm{SI}-0.7 \mathrm{~mm}$ to $-1.6 \mathrm{~mm}$ from bregma. Second, the pSI lies deep to the globus pallidus (GP), lateral to the lateral hypothalamus (LH), and above the optic tract to the amygdala (dorsal to the MeA, dorsomedial to the CeA) (Grove, 1988a; Heimer et al., 1997). The boundary between the GP and pSI can be observed as differential contrast during confocal imaging, and the pSI is below the GP and internal capsule but within $\sim 300 \mu \mathrm{m}$. The optic tract is white matter, so the boundary between the optic tract and the pSI is even clearer. The MeA is immediately below the optic tract and the LH is above the optic tract, we separated the pSI with MeA, LH by comparing the relative position and sizes of the optic tract/GP. Moreover, we co- 
601

602

603

604

605

606

607

608

609

610

611

612

613

614

615

616

617

618

619

620

621

622

623

stained ChAT around the injection site in the virus injection and cannula implantation experiments and found strong ChAT expression in the virus-infected and cannula-implanted sites of the pSI. With these features and boundaries, relative coordinates, and histological differences, we confirmed that the virus injection, cannula implantation, and slice recording experiments were in the pSI and not in surrounding structures.

\section{Anterograde and Retrograde Viral Tracing}

To reveal the outputs of the pSI, anterograde trans-synaptic AAV1-CMV-Cre virus (50 nl/side) was unilaterally injected into the pSI in male Ai14 mice (Zingg et al., 2017). To specifically label the connection from the pSI to the VL/LPAG, AAV1-CMV-Cre virus (50 nl/side) and AAV-DIOmCherry virus (100 nl/side) was unilaterally injected into the pSI, and AAV-DIO-mCherry virus (100 nl/side) was unilaterally injected into the VL/LPAG in C57 mice. To retrogradely trace the input neurons to the VL/LPAG neurons, retrograde AAV2/2Retro-CMV-EGFP virus (60 nl/side) was used to unilaterally infect PAG neurons in C57 male mice (Tervo et al., 2016). The infection of upstream neurons from the VL/LPAG was examined in the aSI and pSI.

To retrogradely trace the monosynaptic presynaptic neurons to the $\mathrm{pSI}^{-\mathrm{PAG}}$ neurons, we used a pseudorabies virus retrograde tracing strategy to trace the presynaptic targets of $\mathrm{pSI}^{-\mathrm{PAG}}$ neurons in male mice. On day 1 , we first injected AAV2/2-Retro-CMV-Cre-EGFP (60 nl/side) into the PAG to retrogradely express Cre in the pSI neurons. Then the Cre-dependent AAV carrying TVA, RG, SAD $\Delta$ G-EGFP (EnvA) and rabies virus (100 $\mathrm{nl} /$ side) was then injected into the pSI neurons at the same site to trace the upstream neurons. On the 15th day, the pseudorabies virus was injected at the same site in the pSI. We checked the range of viral infection in the pSI, and then examined the mCherry+ neurons in the whole brain of the male mice. 
To specifically label the downstream targets from the $\mathrm{pSI}^{-\mathrm{PAG}}$ neurons, retrograde AAV2/2Retro-CMV-EGFP virus (60 nl/side) was used to unilaterally infect PAG neurons in C57 male mice (Tervo et al., 2016). AAV-FLEx-EGFP-2A-Synaptophysin-mRuby (60 nl/side) was then unilaterally injected into the pSI, and the downstream targets of the $\mathrm{pSI}^{-\mathrm{PAG}}$ neurons were examined by checking the Syp: mRuby+ presynaptic termini in the pSI and the regions in the whole brain areas.

AAV1-CMV-Cre virus (50 nl/side) and AAV-DIO-mCherry virus (100 nl/side) was unilaterally injected into the pSI, and AAV-DIO-mCherry virus (100 nl/side) was unilaterally injected into the VL/LPAG in C57 mice. To retrogradely trace the input neurons to the VL/LPAG neurons, retrograde AAV2/2Retro-CMV-EGFP virus (60 nl/side) was used to unilaterally infect PAG neurons in C57 male mice (Tervo et al., 2016). The infection of upstream neurons from the VL/LPAG was examined in the aSI and pSI.

\section{Behavioral Measurements and Video Analysis}

Aggression tests. Behavioral parameters such as the probability of trials with an induced attack, number of attack events, latency to the first attack, and duration of attack in animals with aggressive behaviors were analyzed in most behavioral experiments. Aggression parameters such as the percentage of interrupted attacks in trials, latency to attack offset, and duration of the attack were analyzed in the optogenetic inhibition experiments. The distribution of behavior episodes in Figures 2-7 was calculated as the percentage of trials showing the behavior at different time points, the y-axis of the plot means the percentage of trials showing this behavior. The features of aggression (Moyer, 1968) considered were: (a) various opponents for the tested mice: moving gloves, 1- to 3-day-old naive C57 pups (Wu et al., 2014, Isogai et al., 2018), crickets (Li et al., 2018, Han et al., 2017), and socially- and singly-housed adult C57 or BALB/c 
mice of both sexes (Yang et al., 2017, Hashikawa et al., 2017), and aggressive male CD-1 mice (see below for details for different forms of aggression); (b) various social-contextual conditions: tested mice were singly-housed for 3 days (Figures 4 and 5), singly-housed for 3 weeks (Figures 2-3 and 7), or socially-housed for at least 3 weeks before behavioral tests. During aggression tests, a tested mouse was introduced into the cage of another mouse, into a novel cage, or was resident in its home cage as described in the results; (c) both sexes and mice in different reproductive states were used (Hashikawa et al., 2017), that is, except for the sexuallyexperienced adult males used for the data are shown in Figures 5D-E and 7D-E, adult virgin males and females were used as tested mice; and (d) offensive or defensive aggression: offensive aggression was defined as biting, wrestling, tumbling, or chasing the conspecific, usually targeted toward the back and flanks of the opponent (Blanchard et al., 2003). All the above intraconspecific attack conditions were considered as offensive aggression. A defensive attack was only considered when the mouse bit the snout of the conspecific or displayed upright postures (further details below).

Pup-directed aggression. One- to three-day-old naive C57 pups were used as standard pup intruders in all these behavior assays (Wu et al., 2014, Isogai et al., 2018). The pups were not related to the tested animals. A naive C57 pup was introduced into the home cage of each tested mouse and placed at the farthest corner from the resident's resting nest. The pup was returned to its mother at the end of each assay. The probability of trials with an evoked attack and the latency to attack onset were scored in the optogenetic activation experiments (experiments were stopped if an attack caused actual wounds to the pup). In the optogenetic inactivation experiments and in vivo fiber photometry recording, the probability of trials with an interrupted attack within $3 \mathrm{~s}$, latency to attack offset, and duration of attacks was scored.

Predatory aggression. House crickets (Gryllus domesticus) were purchased from pet food 
672 providers. Five to ten crickets per trial were used in the optogenetics experiments (Han et al.,

6732017 , Li et al., 2018). In the neural activation experiments, the mouse was located in one corner

674 of the cage and crickets were released near the diagonally-opposite corner. Mice fed ad libitum

675 were placed in a clean cage and left for $\sim 10 \mathrm{~min}$ before laser stimulation. Behavioral parameters

676 (percentage of trials with an induced attack, latency to first attack, attack events, and duration of

677 attack) were analyzed only from animals displaying a predatory attack, such as chasing and

678 biting the crickets. In the neural inhibition experiments and in vivo fiber photometry recording,

679 mice were fasted for $24 \mathrm{~h}$. The probability of trials with an interrupted attack within $3 \mathrm{~s}$, latency

680 to attack offset, and duration of attacks was scored.

681 Defensive aggression. Defensive aggression was defined as a reaction to prevent being bitten or threatening a conspecific (Blanchard et al., 2003). A C57 or Thy1-Cre mouse encountered an aggressive CD-1 male in a testing session. Behavioral parameters were analyzed only from animals with aggressive behaviors like upright postures and bites toward the snout. In the 685 optogenetic activation experiments, a 5-min session was used to allow social interactions between the tested mouse and the CD-1 male. Since CD-1 mice are much stronger and more aggressive than the tested C57 or Thy1-Cre mice, tested mice would be socially defeated by CD1 males during this session. Recording for defensive aggression by the tested mice was then started.

Male mating behavior. A sexually-receptive, adult, socially-housed, C57 female was introduced 691 into the home cage of a sexually-experienced, singly-housed, Thy1-Cre male before and after the delivery of CNO or saline. Each test ran for $15 \mathrm{~min}$ and was videotaped and scored for latency to first mounting, mounting events, and duration of mounting (Yang et al., 2013, Yang et al., 2017). All videos were recorded at 30 frames per second, and manual annotations were made by an 
using customized MATLAB programs to characterize and quantify behavioral episodes as previously described (Xu et al., 2012, Wei et al., 2018).

\section{Autonomic Responses}

Heart rate and breathing rate measurements. Heart rate was recorded in freely-moving mice using a pulse oximeter (MAX30100, Maxim Integrated, San Jose, CA). The abdominal area was shaved to enable the red light to pass through to the detector. Recordings were obtained for $\sim 10$ min with intermittent blue laser stimulation in each mouse. Data were collected and analyzed using a custom-written MATLAB program. Breathing rate and episodes of bodily trembling were counted manually, based on chest movements captured on the video (Wang et al., 2015).

Pupil and eye measurement. Mice were adapted to constant, ambient room light for $1 \mathrm{~h}$. Pupillary responses and eye size were measured under infrared light when the animals were head-fixed. The pupil and eye were video-recorded under constant light conditions before, during, and after photostimulation. A blue laser was interleaved and delivered to the pSI (10 times each). Control mice were treated the same except for sham stimulation. The size of the pupil and eye in each frame was determined using a custom-written MATLAB program and the normalized pupil diameter, eye outline, and relative pupil size were later measured and calculated (Wang et al., 2015).

\section{Anxiety and Fear Response Measurements}

Elevated plus maze test. The maze consisted of four arms arranged around a central platform $\left(5 \times 5 \mathrm{~cm}^{2}\right)$ that allowed access to all arms. Mice were placed in the central platform facing the corner between a closed arm and an open arm, and were allowed to explore the maze for 5 min. The test was recorded with a video camera mounted above the maze and connected to a computer. 
The times spent in the open and closed arms were measured and automatically analyzed by ANY-maze (Stoelting Co., Wood Dale, IL).

Open-field test. Mice were placed in the center of a $40 \times 40 \times 40 \mathrm{~cm}$ polystyrene enclosure and videotaped individually. The center area was defined as the central $20 \times 20 \mathrm{~cm}$. To assess the effect of optogenetic activation of pSI neurons on anxiety and locomotor activity, mice were tested in 15-min sessions (consisting of 5-min light OFF, 5-min light ON, and 5-min light OFF periods). Blue laser light $(473 \mathrm{~nm}, 5 \mathrm{~ms}, 40 \mathrm{~Hz}, 15 \mathrm{~s})$ was delivered bilaterally during the light ON phase. To assess the immediate effect of optogenetic activation of pSI neurons on the flight and freezing response, a plastic shield cover (nest) was introduced into the corner of the enclosure, mice were tested in 15-min sessions, consisting of 5-min light OFF, 5-min light ON (15 s off, $15 \mathrm{~s}$ laser on, and $15 \mathrm{~s}$ off), and 5-min light OFF periods. Latency to the nest was counted manually. The time spent in the center area and the velocity of mice were automatically analyzed by ANY-maze.

To investigate the effect of optical inhibition of $\mathrm{pSI}^{\mathrm{Thy} 1}$ neurons on general locomotion, mice were tethered to an optic fiber, habituated in the home cage for $15 \mathrm{~min}$, and then individually placed in the center of a novel plastic arena $(48 \times 48 \times 48 \mathrm{~cm})$ at the start of the session and allowed to freely explore for 9 min in three 3-min epochs (Pre-Laser-Post). During the laser epoch, mice received continuous bilateral optogenetic inhibition with the light intensity same as that optimized for inhibiting attacks on previous testing (3-4 $\mathrm{mW}$ ). The video was captured with an overhead mounted camera. The movement was tracked and measured using automated video-tracking software (ANY-maze).

\section{Feeding Behavior Measurements}

To assess feeding behavior in response to optogenetic inhibition of $\mathrm{pSI}^{\text {Thy1 }}$ neurons, mice were 
744 food-restricted for $24 \mathrm{~h}$ before the experiment. The next day, the mice were habituated in the behavioral context for 15 min after tethering to the bilateral optic fibers. Each inhibition test ran for $\sim 10 \mathrm{~min}$ and was videotaped and scored for the following parameters: latency to feeding

747 offset, probability of feeding trials interrupted within $3 \mathrm{~s}$, duration of feeding, and feeding events. While they were eating, the mice received 15-s photoinhibition with light intensity the same as that optimized for inhibiting attacks in previous tests $(3-4 \mathrm{~mW}, \sim 20$ times, $15 \mathrm{~s}$ ON/OFF). The control test used the same procedure, but the mice received sham blue laser inhibition $(0 \mathrm{~mW}$, $\sim 20$ times, and $15 \mathrm{~s}$ ON/OFF).

\section{HM4Di-mediated Neural Silencing and HM3Dq-mediated Neural Activation}

To label and chronically silence $\mathrm{pSI}^{-\mathrm{PAG}}$ neurons (Armbruster et al., 2007), retrograde AAVRetro-Cre-EGFP (60 nl/side) was used to bilaterally infect PAG neurons, and AAV-hSyn-DIOhM4Di-mCherry (a Cre-dependent pharmacogenetic silencing virus, $150 \mathrm{nl} / \mathrm{side}$ ) was used to bilaterally infect Cre+ pSI neurons in singly-housed male C57 mice. The control singly-housed males were bilaterally injected with AAV-Retro-Cre-EGFP (60 nl/side) in the PAG and AAVhSyn-DIO-mCherry $(150 \mathrm{nl} / \mathrm{side})$ in the pSI. To silence the $\mathrm{pSI}^{\mathrm{Thy} 1}$ neurons, AAV-hSyn-DIOhM4Di-mCherry (a Cre-dependent pharmacogenetic silencing virus, $150 \mathrm{nl} / \mathrm{side}$ ) was directly used to bilaterally infect the $\mathrm{pSI}^{\mathrm{Thy} 1}$ neurons in singly-housed male Thy1-Cre mice. Control male Thy1-Cre mice were bilaterally injected with AAV-hSyn-DIO-mCherry (150 nl/side) in the pSI. Three weeks later, a randomly-selected socially-housed adult C57 male intruder (20-30 g) was introduced and left for $15 \mathrm{~min}$ to evaluate the aggression level of the tested mouse. Mice in the test group were then intraperitoneally injected with $50 \mu \mathrm{l}$ saline or CNO (1 mg/kg, Sigma, C0832, stored at $-20^{\circ} \mathrm{C}$ and dissolved in $0.9 \%$ sterile saline to a volume of $0.5 \mathrm{mg} / \mathrm{ml}$ before use). Thirty minutes after injection, the same behavioral paradigm was repeated for $15 \mathrm{~min}$ to evaluate the 
aggression level of the tested mice again. The neural activation by natural aggression was assessed by c-Fos staining on the next day.

To label and chronically activate the $\mathrm{pSI}^{-\mathrm{PAG}}$ neurons, retrograde AAV-Retro-Cre-EGFP virus (60 nl/side) was used to unilaterally infect PAG neurons, and AAV-hSyn-DIO-hM3DqmCherry (a Cre-dependent pharmacogenetic activating virus, $100 \mathrm{nl} / \mathrm{side}$ ) was used to unilaterally infect the Cre+ pSI neurons in socially-housed male C57 mice. The controls were unilaterally injected with AAV-Retro-Cre-EGFP (60 nl/side) in the PAG and AAV-hSyn-DIOmCherry $(100 \mathrm{nl} / \mathrm{side})$ in the pSI. To activate the $\mathrm{pSI}^{\text {Thy1 }}$ neurons, AAV-hSyn-DIO-hM3DqmCherry (a Cre-dependent pharmacogenetic activating virus, $100 \mathrm{nl} / \mathrm{side}$ ) was directly used to unilaterally infect the $\mathrm{pSI}^{\mathrm{Thy} 1}$ neurons in socially-housed male Thy1-Cre mice. The control male Thy1-Cre mice were unilaterally injected with AAV-hSyn-DIO-mCherry (100 nl/side) in the pSI. Three weeks later, the mice were intraperitoneally injected with $25 \mu 1$ saline or CNO $(0.5 \mathrm{mg} / \mathrm{kg})$, and a randomly-selected singly-housed adult C57 male intruder (20-30 g) was introduced into the home cage of the tested mouse and left for 15 min to evaluate the aggression level of the pharmacogenetically-activated and control mice. Thirty minutes after injection, the same behavioral paradigm was run for 15 min to evaluate the aggression level of the mice again. The neural activation by $\mathrm{CNO}(0.5 \mathrm{mg} / \mathrm{kg})$ was assessed by c-Fos staining on the next day.

\section{ChR2-mediated Neural Activation}

To label the $\mathrm{pSI}^{-\mathrm{PAG}}$ neurons and activate them in a time-locked manner (Boyden et al., 2005), retrograde AAV-Retro-Cre-EGFP (60 nl/side) was used to unilaterally infect PAG neurons, and AAV-Ef1 $\alpha$-DIO-hChR2 (H134R)-EYFP (a Cre-dependent optical activating virus, 150 nl/side) was used to unilaterally infect the Cre+ pSI neurons in male and female C57 mice. The controls were unilaterally injected with AAV-Retro-Cre-EGFP (60 nl/side) in the PAG and AAV-Ef1 $\alpha$ - 
DIO-EYFP (100 nl/side) in the pSI. To optogenetically activate pSI ${ }^{\text {CaMKII } \alpha}$ neurons, C57 males and females were unilaterally injected with AAV-CaMKII $\alpha$-hChR2 (H134R)-mCherry (60 nl/side) in the pSI. The control animals were unilaterally injected with AAV-CaMKII $\alpha$-mCherry (60 $\mathrm{nl} /$ side) in the pSI. After injection, mice were allowed 3-4 weeks to recover. For in vivo optogenetic manipulation, an optical fiber cannula $(200 \mu \mathrm{m})$ was implanted into the right pSI. To acutely manipulate the pSI-PAG, pSI-BNST or pSI-VMH circuit, an optical fiber cannula (200 $\mu \mathrm{m})$ was implanted into the right VL/LPAG, BNST, or VMH. The optical fiber was connected to a laser source using an optical fiber sleeve. The light intensity was the same as that optimized for eliciting attacks on previous testing days $(5 \mathrm{~ms}, 5-40 \mathrm{~Hz}, 0-3.50 \mathrm{~mW}, 20$ times, $15 \mathrm{~s}$ ON and $15 \mathrm{~s}$ OFF). Randomly-selected socially- or singly-housed adult males or females were introduced into the home cage of the tested mouse, one at a time and each for 10-20 min. Mice with missed injection or cannula placements were excluded. Control mice expressing only EYFP/mCherry underwent the same procedure and received the same intensity of laser stimulation. For the intensity modulation assay, the $\mathrm{pSI}^{-\mathrm{PAG}}$ neurons were photostimulated with 14 different light intensities $(0,0.03,0.10,0.17,0.26,0.34,0.40,0.68,1.17,1.58,1.98,2.24,2.70$, and $2.98 \mathrm{~mW})$ in diverse aggressive behaviors in male and female mice (Figure 6). Different laser intensities were delivered in a pseudo-random order and each intensity of laser $(5 \mathrm{~ms}, 40 \mathrm{~Hz}, 15 \mathrm{~s} \mathrm{ON}$ and 30 s OFF) for five types of aggression were tested for 5-8 trials. 1- to 3-day-old naive C57 pups, crickets, adult $\mathrm{C} 57$ or BALB/c mice of both sexes were introduced as the opponents, the tested male and female mice were socially-housed for at least 3 weeks before behavioral tests (see the above description of aggression tests). A plot of $\log$ (photostimulation intensity) vs aggressive behaviors was fitted with the nonlinear sigmoidal curve (yielded a nonlinear relationship).

To optogenetically activate the $\mathrm{pSI}^{\mathrm{Thy} 1}$ neurons projecting to the PAG, Thy1-Cre male mice were unilaterally injected with rAAV-CAG-retro-FLEX-Flpo mixed with CTB555 (Dilution ratio 
$816=4: 1,100 \mathrm{nl} /$ side $)$ in the PAG and AAV-fDIO-hChR2 (H134R)-EYFP (100 nl/side) in the SI.

817 Three weeks later, we used the same aggression behavioral protocol (see above) to test the role of $\mathrm{pSI}^{\mathrm{Thy} 1}$ neurons projecting to the PAG in inter-male aggression and predatory aggression.

\section{ChR2-mediated Neural Activation before and after Acute Social Defeat}

821 To optogenetically activate $\mathrm{pSI}^{-\mathrm{PAG}}$ neurons before and after ASD by CD1 mice, the right PAG of intensity of laser ( $5 \mathrm{~ms}, 40 \mathrm{~Hz}, 15 \mathrm{~s} \mathrm{ON}$ and $30 \mathrm{~s} \mathrm{OFF})$ was tested for 5-8 trials. To explore the 
840 To label and silence in a time-locked manner the $\mathrm{pSI}^{\text {Thy1 }}$ neurons or the $\mathrm{pSI}^{\text {Thy1 }}$ neural terminals

841 in the VL/LPAG, AAV-EF1a-DIO-GtACR1-P2A-GFP-WPRE (a Cre-dependent optogenetic

842 silencing virus, $150 \mathrm{nl} /$ side) was used to bilaterally infect the $\mathrm{pSI}^{\text {Thy1 }}$ neurons in singly-housed

843 male Thy1-Cre mice. For in vivo optogenetic manipulation in awake behaving animals, optical

844 fiber cannulas (diameter, $200 \mu \mathrm{m}$ ) were bilaterally implanted into the pSI or the VL/LPAG. Three

845 weeks after viral infection, a randomly-selected socially-housed adult male intruder was

846 introduced into the home cage of the tested mouse and left for $\sim 15$ min to evaluate the

847 aggression level of the singly-housed adult male Thy1-Cre mouse. To assess the effects of

848 optogenetic inhibition of $\mathrm{pSI}^{\text {Thy1 }}$ neurons, five types of robust natural aggressive behaviors were

849 used (offensive inter-male aggression, when a singly-housed Thy1-Cre male in its home cage

850 attacked a socially-housed C57 male mouse; offensive male-female aggression, when a singly-

851 housed Thy1-Cre male in its home cage attacked a socially-housed C57 female mouse; offensive

852 female-male aggression, when a singly-housed Thy1-Cre female in its home cage attacked a

853 socially-housed C57 male mouse; pup-directed aggression, when a singly-housed Thy1-Cre

854 virgin male in its home cage attacked a pup; and predatory aggression, when a singly-housed

855 Thy1-Cre virgin male in its home cage attacked crickets, see Figure 7. Each inhibition test ran

856 for $\sim 15 \mathrm{~min}$ and was videotaped and scored for the following parameters: latency to attack offset,

857 probability of attack trials interrupted within $3 \mathrm{~s}$, duration of the attack, and attack distribution.

858 The light intensity was the same as that optimized for inhibiting attacks on previous testing days

859 (3-4 mW, 20 times, and $15 \mathrm{~s}$ ON/OFF). Mice with the missed injection or cannula placements

860 were excluded. Control mice underwent the same procedure and received the same intensity of

861 laser stimulation. 
Following AAV-EF1a-DIO-GCamp6m or AAV-EF1a-DIO-EYFP injection in Thy1-Cre males, an optical fiber $(230 \mu \mathrm{m}$ OD, $0.37 \mathrm{NA})$ was placed in a ceramic ferrule $(2.5 \mathrm{~mm} \mathrm{OD}, 126 \mu \mathrm{m}$ ID) and inserted toward the pSI. The ferrule was affixed with a skull-penetrating M1 screw and dental acrylic. To enable recovery and AAV expression, mice were housed individually for at least 10 days after virus injection. A fiber photometry system (Thinker Tech Nanjing Biotech Ltd, Nanjing, China) was used for recording (Gunaydin et al., 2014, Li et al., 2018). To record fluorescence signals, the beam from a 488-nm laser (OBIS 488LS; Coherent, Santa Clara, CA, USA) was reflected with a dichroic mirror and focused with a $10 \times$ objective lens $(\mathrm{NA}=0.3$; Olympus, Tokyo, Japan). An optical fiber (230 $\mu \mathrm{m}$ OD, NA $=0.37 ; 2 \mathrm{~m}$ long) guided the light between the commutator and the implanted optical fiber. To minimize GCaMP bleaching, the laser power at the tip of the optical fiber was adjusted to a low level $(0.03-0.04 \mathrm{~mW})$. The GCaMP6 fluorescence was filtered with an EYFP bandpass filter and collected by a photomultiplier tube (R3896; Hamamatsu Photonics). An amplifier converted the photomultiplier current output to a voltage signal, which was further filtered through a low-pass filter (40 Hz cut-off; Brownlee 440). The analog voltage signals were digitized at $500 \mathrm{~Hz}$ (Power 1401 digitizer, Cambridge Electronic Design) and sampled with software (TDMS). Fiberphotometric recording data were exported as MATLAB files for further analysis, and fiber photometry-related aggression behavioral data were analyzed using MATLAB. All the raw fluorescence data $(F)$ were smoothed with a moving average filter (10-ms span) and then segmented and aligned to the onset of behavioral events within individual trials or bouts. The fluorescence change values $(\Delta F / F)$ were calculated as $(\mathrm{F}-\mathrm{F} 0) /\left(\mathrm{F} 0-\mathrm{V}_{\text {offset }}\right)$, where $\mathrm{F} 0$ is the baseline fluorescence signal averaged over a 2-s/4-s time-window prior to a trigger event and $\mathrm{V}_{\text {offset }}$ is the fluorescence signal recorded before the cannula was connected to the optical fiber above the pSI. $\Delta F / F$ values are presented as heatmaps or average plots with a shaded area 
indicating the SEM.

On testing days, a water port and food were left inside the tested mouse's cage for $\sim 10$ min. During that period, the mouse was free to approach, lick, and/or eat. A non-aversive stimulus consisting of an object (a cotton ball without liquid), or a cotton ball with $10 \mu 1$ DMSO (dimethyl sulfoxide), male urine, or TMT (2, 5-dihydro-2, 4, 5-trimethylthiazoline) was then left for $\sim 10$ min in the home cage of a subject Thy1-Cre mouse. The aversive stimuli were air-puffs (delivered by a hand-pumped compressor with its opening $\sim 3 \mathrm{~cm}$ from the mouse's nares; one press of the pump generated a gentle $\sim 0.5$-s puff), tail suspension (the tail was gripped and the mouse lifted off the floor of its cage for $\sim 4 \mathrm{~s}$, with at least $30 \mathrm{~s}$ between each lift), and a flying object (a flattened glove was introduced into the tested mouse's cage above its head, and then approached its body). The onset of each stimulus triggered data alignment. Social and non-social entry refers to the threat period after an intruder mouse (female C57, male C57, male CD-1, or male C57 entry preceding attack) or object (a 10-ml plastic centrifuge tube) was first introduced into the home cage of a subject Thy1-Cre mouse. The time of each entry triggered data alignment. Aggressive social behaviors of these subject Thy1-Cre mice were recorded during the application of various contextual cues.

We calculated the average $\Delta F / F$ during the following stimuli and aggressive behaviors: offensive inter-male attack (all attack), first attack (an attack not followed by another attack within $4 \mathrm{~s}$ ), continuous attack (an attack following or followed by another attack within $4 \mathrm{~s}$ ), last attack (a continuous attack not followed by another attack within 4 s), sniff without attack (a sniff not followed by an attack within 4 s), sniff preceding attack, rattle without attack (a rattle not followed by an attack within $4 \mathrm{~s}$ ), rattle preceding attack, threat (subject male mouse threatened other males with boxing postures but no bite), male-female attack, defensive intermale attack, predatory approach and attack, pup-directed approach and attack, female-male sniff 
912 and attack, and multiple social and non-social cues based on the peristimulus time histograms

913 (PSTHs). The non-parametric Wilcoxon signed-rank test or t-test was used to determine whether

914 the AUC per second before, during and after events were significantly different from control (2/4

$915 \mathrm{~s}$ before a trigger event).

\section{Decoder Analysis by the Support Vector Machine (SVM) Algorithm}

918 Population decoding analysis was used to evaluate whether diverse aggressive behaviors could 919 be extracted based on the $\mathrm{pSI}^{\mathrm{Thy} 1}$ neuronal $\mathrm{Ca}^{2+}$ profile of individual trials. Analysis with the support vector machine (SVM) algorithm was performed with the LIBSVM library (https://www.csie.ntu.edu.tw/ cjlin/libsvm) according to the library’s documented instructions.

To study the correlation of behavioral performance and population neuronal decoding, decoder. The total number of trials of types of social behaviors ranged from 26 to 680. To ensure that the result came from sampling all trials rather than a limited number of them, we alternated the number of trials (from 10 to 150 ) in the calculations and used the classification accuracy test with the SVM with the linear kernel or the radial basis function (RBF) kernel. The classification accuracy from the linear kernel was better than the RBF kernel with default parameters, and the sampling results suggested the classification accuracy of a pre-selected 50 trials was relatively higher and suitable to the test in the social behaviors with limited collected trials. Thus, 50 trials

931 of the $\mathrm{Ca}^{2+}$ signals for each type of social behavior were randomly selected for the classification 932 accuracy test with the linear kernel, and the $\mathrm{Ca}^{2+}$ signals for each behavior trial were binned into 933 10-ms windows and grouped by social behavior type. The $\mathrm{Ca}^{2+}$ signals were normalized to the [0, 934 1] range. In each calculation, $90 \%$ of the trials were randomly partitioned to a training set, and 935 the remaining $10 \%$ was used as the test set, with no overlap between the training and testing sets. 
All trials were then randomly re-partitioned, and the training and testing repeated 10 times. The SVM was trained with the training set, and the trained SVM was used to classify the test set. Each of the results was labeled as correct if the classified label matched the behavioral type, or incorrect otherwise. Because the training and testing set never overlapped and all trials were likely to be used in both the training and testing sets due to the large repetition number, the average decoding accuracy was equal to the cross-validation accuracy in a resampled form. For the recording group and shuffled control group, the procedure was repeated 1000 times with the behavioral label for each trial randomly re-partitioned and redistributed.

Bar plots of decoder accuracy were generated using held-out test data for a cross-validated SVM decoder trained on the time-averaged responses of population neuronal activity in a window from $4 \mathrm{~s}$ before to $8 \mathrm{~s}$ after stimulus presentation. Time-evolving plots of decoder accuracy were constructed by training a separate cross-validated decoder on the time-averaged activity of population neuronal activity in 10-ms sliding steps from $4 \mathrm{~s}$ before to $8 \mathrm{~s}$ after stimulus presentation. Decoder performance is reported as the average prediction accuracy on the held-out test data; chance accuracy is $1 / 2$ for the two-class decoder and $1 / 3$ for the three-class decoder.

\section{Single-unit Recording and Data Analysis}

Modified electrode arrays were implanted dorsal to the pSI (Lin et al., 2007). The electrodes consisted of 32 single microwires (California Fine Wire Co., Grover Beach, CA, USA). One ground wire was soldered to a 32-channel connector (Omnetics Connector Corp., Minneapolis, MN, USA). Mice were allowed to recover for at least 7 days, and then the electrodes were connected to a 32-channel preamplifier head-stage (Plexon Inc., Dallas, TX, USA). Twenty-four hours after recording the activity of a pSI neuron, a behavioral test was given to examine the 
firing pattern of the same neuron. During the recording sessions, all signals recorded from each electrode were amplified, filtered between $0.1 \mathrm{~Hz}$ and $10 \mathrm{kHz}$, and spike waveforms were digitized at $40 \mathrm{kHz}$. Spikes were sorted using the software Offline Sorter (Plexon). Units were accepted only if a distinct cluster was visible in a two-dimensional plot of the largest two principal components. In total, 9 mice were implanted with electrodes and used for data collection. Neurons with mean firing rates $>0.5 \mathrm{~Hz}$ were included in the analysis. Then analysis was performed using MATLAB, referencing neural activity to behavior. A given neuron that significantly responded to a defined behavior would be reflected by its reliable responses across different trials. The responses of each neuron were averages of 2-20 behavior trials. We then calculated the averaged response during attack, investigation of object, and male, based on the $\mathrm{z}$ scored PSTHs. For each recorded unit, PSTHs were z-score transformed by subtracting the mean firing rate and dividing by the standard error of each unit's firing rate. To test the significance of changes in firing rate, we used individual unit analysis. A non-parametric Wilcoxon signed-rank test was performed on each unit to determine whether the mean firing rate during the event (e.g., attack, sniffing object, and sniffing male) was significantly different from baseline (from $-2 \mathrm{~s}$ to $-1 \mathrm{~s}$ ), and units were classified into three populations: excited, inhibited, or not changed. The responses and relative proportions of attack-excited, attack-inhibited, and attack-no-response units before and during the events were compared using the t-test.

\section{In Vitro Electrophysiology}

Mice were deeply anesthetized with pentobarbital sodium (100 mg/kg, i.p.) and decapitated. The whole brain was quickly dissected into ice-cold oxygenated artificial cerebrospinal fluid (aCSF), then cut coronally into 300- $\mu \mathrm{m}$ slices on a microtome (VTA-1200S; Leica). Slices containing the pSI were transferred to an incubation chamber filled with aCSF and incubated for at least $1 \mathrm{~h}$ at 
room temperature $(\mathrm{RT})\left(24-26^{\circ} \mathrm{C}\right)$. At RT, the slices were transferred to a recording chamber on the stage of a fluorescence microscope (BX51WI; Olympus). Patch electrodes were pulled from borosilicate capillaries (BF150-86-10; Sutter Instrument Co, Novato, CA, USA). Recordings were made with a MultiClamp 700B amplifier (Molecular Devices). Signals were low-pass filtered at $10 \mathrm{kHz}$ and digitized at $10 \mathrm{kHz}$ (MICRO3 1401, Cambridge Electronic Design). Data were acquired and analyzed using Spike2 7.04 software (Cambridge Electronic Design). For photostimulation of pSI neurons, an optical fiber (diameter $200 \mu \mathrm{m}$ ) was coupled to a 473-nm LED. The fiber was glued to a stainless-steel tube (ID $250 \mu \mathrm{m}$, OD $480 \mu \mathrm{m}$ ). The tip of the fiber was trimmed and polished, submerged in aCSF, and positioned above the stimulation site. The blue light was controlled by a pulse stimulator (PG-4000A; Cygnus Technologies, Southport, NC, USA). Whole-cell patch-clamp recordings under both voltage and current clamp were performed in neurons that expressed EYFP/mCherry fluorescence. To test for the effects of photostimulation, LED-generated blue light pulses at different frequencies $(5,10,20$, and $40 \mathrm{~Hz})$ were applied to recorded neurons. For recordings from virus-infected neurons, pipettes were filled with a $\mathrm{K}^{+}$-based low $\mathrm{Cl}^{-}$internal solution containing (in mM) $145 \mathrm{KGlu}, 10 \mathrm{HEPES}, 0.2$ EGTA, $1 \mathrm{MgCl}$, 4 Mg-ATP, 0.3 Na2-GTP, 10 Na2-Phosphocreatine (pH 7.3 adjusted with KOH; $295 \mathrm{mOsm})$. Membrane potentials were corrected for $\sim 10 \mathrm{mV}$ liquid junction potential. To test for the effects of pharmacogenetic activation or inhibition of $\mathrm{pSI}^{\text {Thy1 }}$ neurons, 5 or $10 \mu \mathrm{M} \mathrm{CNO}$ was added to the aCSF perfusion. To test the effects of optogenetic inhibition of $\mathrm{pSI}^{\text {Thy1 }}$ neurons, LED-generated blue light pulses at constant frequencies were applied to the recorded GtACR1expressing $\mathrm{pSI}^{\text {Thy1 }}$ neurons. To test the excitatory effects of photoactivation of $\mathrm{pSI}^{\mathrm{Thy} 1}$ projection terminals on VL/LPAG neurons (Figure S7), LED-generated blue light pulses at a constant frequency were applied to the recorded PAG neurons. The light-evoked currents in the VL/LPAG neurons by photostimulating axonal projections from the pSI to these neurons were recorded in 
the absence or presence of the bath-applied glutamate receptor antagonist CNQX $(20 \mu \mathrm{M})$, and the GABA receptor antagonist Picrotoxin $(100 \mu \mathrm{M})$.

\section{Histology}

After experiments, the mice were anesthetized and perfused with saline followed by $4 \%$ paraformaldehyde in $0.1 \mathrm{M}$ phosphate buffer (PBS). The brain was then removed and placed in $4 \%$ paraformaldehyde buffer at $4^{\circ} \mathrm{C}$ for overnight fixation, after which the brain was cryoprotected in $30 \%$ sucrose $(\mathrm{wt} / \mathrm{vol})$ at $4^{\circ} \mathrm{C}$. Coronal sections were cut at $40 \mu \mathrm{m}$ on a cryostat (Leica CM1900) for imaging. After rinsing with $0.3 \%$ Triton-X 100 (vol/vol) in $0.1 \mathrm{M}$ PBS (30 min) or ice-cold methanol (10 min) and blocking with $10 \%(\mathrm{wt} / \mathrm{vol})$ normal bovine serum for $1 \mathrm{~h}$ at room temperature, sections were incubated with the following primary antibodies $\left(12-24 \mathrm{~h}\right.$ at $\left.4^{\circ} \mathrm{C}\right)$ : anti-GAD67 (1:500, mouse, Millipore), anti-GAD65/67 (1:400, rabbit, Abcam), anti-ChAT (1:200, rabbit, Millipore), anti-CaMKII (1:200, rabbit, Abcam), and anti-c-Fos (1:2500, rabbit, Calbiochem). After rinsing, sections were incubated with fluorophore-conjugated secondary antibody (1:1000; Millipore) for $2 \mathrm{~h}$ at RT. Antibodies were diluted in PBS containing 4\% bovine serum albumin and $0.2 \%$ Triton $\mathrm{X}$-100. To induce natural aggression in males for c-Fos quantification, a socially-housed adult male intruder (C57) was introduced into the home cage of a highly sexually-experienced adult male C57 resident mouse or male Thy1-Cre resident mouse (AAV-DIO-EYFP virus was injected into the pSI in the Thy1-Cre mice two weeks before) for 10 min of aggression. Resident mice showing the only investigation but not attack toward intruders in the 10-min test period were used as a control group. To assess the activation of pSI neurons by optogenetics or pharmacogenetics, adult male mice were singly housed in their home cage on the first day, and the mice were stimulated with light for $10 \mathrm{~min}(5 \mathrm{~ms}, 40 \mathrm{~Hz}, 1-2 \mathrm{~mW}, 20$ times, 15 s ON and 15 s OFF) or were intraperitoneally injected with $\mathrm{CNO}(0.5 \mathrm{mg} / \mathrm{kg})$ on the next day. 
1032 These mice were perfused $1.5 \mathrm{~h}$ later, and sections were cut as described above. After the anti-c-

1033 Fos immunohistochemistry reaction, nuclei were stained with DAPI, and confocal images were

1034 captured using 10×, 20×, and 60× objectives (Olympus FV-1200). Cell counting was carried out 1035 manually using Fiji (NIH).

1036

\section{QUANTIFICATION AND STASTISTICAL ANALYSIS}

1038 No statistical methods were used to pre-determine sample sizes. All data were randomly 1039 collected. We first determined whether the data values came from a normal distribution with the 1040 D'Agostino-Pearson omnibus, Shapiro-Wilk, and Kolmogorov-Smirnov normality tests. In 1041 experiments with paired samples, we used a two-tailed paired t-test and the Wilcoxon matched1042 pairs signed-rank test for parametric and non-parametric data, and the Friedman test for 1043 nonparametric data. In all other experiments, we used a t-test, the t-test with Welch's correction 1044 for unequal standard deviation, or ANOVA for parametric data, and a Mann-Whitney or Kruskal1045 Wallis test for non-parametric data. All values were calculated with Prism 6.0 or MATLAB. 


\section{Supplemental Figure Legends}

1049 Figure S1. Substantia Innominata in the Mouse and Human Brain Reference Atlases, 1050 Related to Figure 1

1051 (A) Structure of the substantia innominata (SI) as shown in the EPFL Blue Brain Reference Atlas 1052 (2019) (https://bbp.epfl.ch/nexus/cell-atlas/).

1053 (B) The SI as shown in the Allen Mouse Brain Reference Atlas (2011, http://mouse.brain1054 map.org/static/atlas). The anatomical reference atlas illustrates the SI (purple) in the adult mouse 1055 brain in coronal planes (from left to right, planes 60, 63, and 66).

1056 (C) The SI as shown in the Allen Human Brain Reference Atlas (using modified Brodmann 1057 annotation, http://atlas.brain-map.org/atlas?atlas=265297126). The anatomical reference atlas 1058 illustrates the SI (purple) in an adult human brain (32 years old) in coronal planes (from left to 1059 right, planes 27, 32, and 37). 
Figure S2. Correlation of pSI ${ }^{\text {Thy1 }}$ Neuronal $\mathrm{Ca}^{2+}$ Dynamics with Attack Patterns, Related to Figure 2

1063

(A) Setup for fiber photometric recording in $\mathrm{pSI}^{\text {Thy1 }}$ neurons during inter-male aggression.

1064

(B) Overlay of EGFP (left) and GCaMP6m (middle) expression in the pSI. Right panel, a

1065 representative image (scale bar, $100 \mu \mathrm{m}$ ) of GCaMP6m (green) and the optical fiber track.

1066 (C) An example raster plot of single attack distribution from 11 mice.

1067

(D) Summarized distribution of attack episodes plotted by the percentage of trials showing attack

1068 at different time points $(\mathrm{n}=458$ attacks $)$.

1069

(E) Heatmap of GCaMP6m $\Delta F / F$ signals from pSI neurons in aggression ( $\mathrm{n}=458$ attack trials).

1070

(F) Representative $\Delta F / F$ of GCaMP6m (magenta) and EYFP (gray) signals before, during, and after an attack. Note that the elevation of $\mathrm{Ca}^{2+}$ signaling $(\mathrm{t}=-1.2 \mathrm{~s})$ preceded the attack behavior 1072 (onset at $\mathrm{t}=0 \mathrm{~s}$ ).

1073 (G) Time windows of $\mathrm{pSI}^{\text {Thy1 }}$ neuronal activation before, during, and after attacks.

1074 (H) Area under the curve (AUC) per second (left) and peak $\Delta F / F$ (right) of GCaMP6m and 1075 EYFP signals before, during, and after an attack. Mann-Whitney test and Wilcoxon matched1076 pairs signed-rank test; *** $P<0.001$ between the groups indicated. '\#' and ' $\&$ ' above each bar indicate that the AUC per second (left) or peak $\Delta F / F$ (right) during each behavior period was $(P$ $<0.001)$ and wasn't $(P>0.05)$ significantly changed compared with the EYFP group, determined by Mann-Whitney test.

1080 (I) Distribution of the incidence of single attacks and continuous attacks with different episode 1081 orders.

1082 (J) Representative GCaMP6m signals during a single attack (upper) and continuous attacks with 1083 different episode orders (lower). Green bars, episodes of attack.

1084 (K-M) From top to bottom: distribution of attack behavior episodes, heatmaps of GCaMP6m $\Delta F / F$ signals from $\mathrm{pSI}^{\text {Thy1 }}$ neurons, time windows of $\mathrm{pSI}^{\text {Thy1 }}$ neuronal activation, and $\Delta F / F$ of the EYFP and GCaMP6m signals from $\mathrm{pSI}^{\text {Thy1 }}$ neurons before, during, and after single attacks (K, $\mathrm{n}$ $=165$ trials $)$ and the first $(\mathrm{L}, \mathrm{n}=99$ trials $)$ and last $(\mathrm{M}, \mathrm{n}=99$ trials $)$ episodes of continuous 1088 attacks.

1089 (N) Peak $\Delta F / F$ of EYFP and GCaMP6m signals before, during, and after single attacks (left) and 1090 the first (middle) and last (right) episodes of continuous attacks. The EYFP and GCaMP6m signals in each type of attack behavior were compared using the Mann-Whitney test, Wilcoxon matched-pairs signed-rank test, and two-tailed paired t-test; from left to right, $* * * P<0.001$, $* * * P<0.001, * * P=0.0049$, *** $P<0.001$, *** $P<0.001, P=0.5349$. The GCaMP6m signals in the three types of attack behavior were compared using the Mann-Whitney test; $* * * P<0.001$. '\#' above each bar indicates that peak $\Delta \mathrm{F} / \mathrm{F}$ (right) during each behavior period was significantly 
$1096 \quad(* * P<0.01)$ changed compared with the EYFP group, determined by Mann-Whitney test.

1097 (O) Averaged $\Delta F / F$ of GCaMP6m dynamic signaling of continuous attacks with different episode 1098 orders.

1099 (P) Peak $\Delta F / F$ of GCaMP6m signals before, during, and after continuous attacks with different 1100 episode orders. Mann-Whitney test, unpaired t-test, and Kruskal-Wallis test; from left to right, $1101 * * * P<0.001$, *** $P<0.001, P=0.2623, P=0.9688, P=0.9867, * P=0.0189$, ** $P=0.005$.

1102 ns, not significant.

1103 Data are presented as the mean \pm SEM. 
Figure S3. Correlation of Different Aggressive Behaviors with the Differential Calcium

\section{Activity Levels in pSI ${ }^{\text {Thy1 }}$ Neurons, Related to Figures 2-3, and S2}

1106 (A) Distribution of attack episodes ( $\mathrm{n}=458$ attacks, upper) and representative $\Delta F / F$ of 1107 GCaMP6m signals before and during attacks ( $\mathrm{n}=458$ attacks, lower). Note that elevation of the $1108 \mathrm{Ca}^{2+}$ signal $(\mathrm{t}=-1.2 \mathrm{~s}$ ) preceded the attack behavior (onset at $\mathrm{t}=0 \mathrm{~s}$ ).

1109 (B) Linear regression of the AUC per second of GCaMP6m signals prior to the attack behavior 1110 and probability of all_pre attacks (attacks during the 4s window prior to all episodes of attack 1111 behavior, $\mathrm{n}=458$ ).

1112 (C) Distribution of last attack episodes $(\mathrm{n}=99$ attacks, upper) and representative $\Delta F / F$ of 1113 GCaMP6m signals before, during, and after the last episode of continuous attacks ( $\mathrm{n}=99$ attacks, 1114 lower).

1115 (D) Linear regression of the AUC per second of GCaMP6m signals and probability of last_pre 1116 attacks (attacks during the $4 \mathrm{~s}$ window prior to the last episode of continuous attacks, $\mathrm{n}=99$ ).

1117 (E) Peak $\Delta F / F$ of GCaMP6m in all attack behavior, single attack behavior, and the first and last 1118 episodes of attack behavior. $P=0.1270$, Kruskal-Wallis test.

1119 (F) Sample decoding accuracy of the pSI neuronal $\mathrm{Ca}^{2+}$ signals in single and the first episode of 1120 continuous attack trials.

1121 (G) Averaged decoding accuracy of pSI neuronal activity before, during, and after attack trials 1122 under recording and shuffled conditions. '\#' above each bar indicates that the decoding accuracy 1123 during each behavior period was significantly increased $(P<0.05)$ compared with that in the 1124 shuffled period, assessed by the Mann-Whitney test. Decoding accuracy in recording differences 1125 before, during, and after attack trials was assessed by the Mann-Whitney test. From left to right, $1126 \quad * * * P<0.001, * * * P<0.001$.

1127 (H) Sample decoding accuracy of pSI neuronal $\mathrm{Ca}^{2+}$ signals in single and the last episode of 1128 continuous attack trials.

1129 (I) Averaged decoding accuracy of pSI neuronal activity before, during, and after attack trials 1130 under recording and shuffled conditions. Decoding accuracy in recording differences before, 1131 during and after attack trials was assessed by the Mann-Whitney test. From left to right, ***P $1132<0.001, * * * P<0.001$.

1133 (J) Averaged $\Delta \mathrm{F} / \mathrm{F}$ of $\mathrm{Ca}^{2+}$ signals in pSI neurons before, during, and after male-male, female1134 male, predatory, and pup-directed attacks.

1135 (K) Peak $\Delta \mathrm{F} / \mathrm{F}$ of $\mathrm{Ca}^{2+}$ signals during diverse attacks. Comparison of diverse attacks was 1136 determined by Monte Carlo simulation with a subset of the male-male data 2000 times. $P$-value 1137 of comparison of subset of $\mathrm{Ca}^{2+}$ data associated with the diverse attacks was determined by the 1138 Wilcoxon rank-sum test. 'ns $(96.95 \%)$ ' indicates that these two samples were not significantly 

from populations with identical distributions. '*** $(0.20 \%)$ ' indicates that these two samples was significantly different $(P<0.001)$, and Monte Carlo simulation showed that $0 \%$ of 2000 comparisons were from populations with identical distributions.

1143 (L-Q) Sample decoding accuracy of the pSI neuronal $\mathrm{Ca}^{2+}$ signals and averaged sample decoding accuracy of pSI neuronal activity under recording and shuffled conditions compared between the cricket-directed approach and predatory attack trials (L, M), the pup-directed approach and pupdirected attack trials ( $\mathrm{N}, \mathrm{O})$, and the female-male sniff and female-male attack trials (P, Q). '\#' above each bar indicates that decoding accuracy during each behavior period was significantly higher $(P<0.05)$ than that in the shuffles period, determined by the Mann-Whitney test. Decoding accuracy in recording differences before, during, and after attack trials was determined by the Mann-Whitney test. From left to right, $* * * P<0.001$, $* * * P<0.001$. (R-W) Sample decoding accuracy of the pSI neuronal $\mathrm{Ca}^{2+}$ signals and averaged sample decoding accuracy of pSI neuronal activity under recording and shuffled conditions compared between the cricket-directed approach and approach (attack) trials (R, S), the pup-directed approach and approach (attack) trials $(\mathrm{T}, \mathrm{U})$, and the female-male sniff and sniff (attack) trials $(\mathrm{V}$, $\mathrm{W})$. From left to right, $* * * P<0.001$, $* * * P<0.001$. accuracy of pSI neuronal activity under recording and shuffled conditions in cricket-directed, pup-directed, female-male, and inter-male approaches or sniffs (left), approaches or sniffs preceding an attack (middle), and attack trials (right).

(Y) Averaged sample decoding accuracy in four types of approaches/sniffs, approaches/sniffs preceding attacks, and attacks under recording conditions as shown in (AB). '\#' or ' $\&$ ' above each bar indicates that the decoding accuracy during each behavior period was $(P<0.05)$ or was not $(P>0.05)$ significantly higher than that before each behavior period, determined by the Mann-Whitney test. Decoding accuracy in recording differences in the three behaviors was determined by the Mann-Whitney test. From left to right, $* * * P<0.001$, *** $P<0.001$.

1166 (Z) Sample decoding accuracy of the pSI neuronal $\mathrm{Ca}^{2+}$ signals under recording and shuffled 1167 conditions in predatory, pup-directed, female-male, inter-male, male-female, and inter-male 1168 defensive attack trials).

1169 (AA) Averaged sample decoding accuracy under recording and shuffled conditions. '\#' above 1170 each bar indicates that the decoding accuracy during each behavior period was significantly $(P$ $1171<0.05)$ higher than that before each behavior period, determined by the Mann-Whitney test. 1172 Decoding accuracy in recording differences was determined by the Mann-Whitney test. From left to right, $* * * P<0.001, * * * P<0.001$. 
bioRxiv preprint doi: https://doi.org/10.1101/2020.04.22.047670; this version posted February 19, 2021. The copyright holder for this preprint (which was not certified by peer review) is the author/funder, who has granted bioRxiv a license to display the preprint in perpetuity. It is made available under aCC-BY-NC-ND 4.0 International license.

1175 Data are presented as the mean \pm SEM. 


\section{Cues, Related to Figure 3}

1178 (A) Setup for aggressive behaviors recording in response to diverse non-social and social stimuli.

1179 (B) Distribution of episodes of attack behavior during water consumption ( $\mathrm{n}=52$ trials), food 1180 consumption $(n=260$ trials), approach a cotton ball $(n=23$ trials $)$, during detection of DMSO ( $n$ $1181=30$ trials $)$, approach a urine cotton ball $(n=36$ trials $)$, object entry $(n=39$ trials $)$, female C57 1182 entry $(\mathrm{n}=39$ trials), and approach a TMT cotton ball $(\mathrm{n}=57$ trials).

1183 (C) Distribution of episodes of attack behavior in response to air puff ( $\mathrm{n}=322$ trials), the threat of a flying glove ( $n=567$ trials), tail suspension $(n=142$ trials), male CD-1 entry ( $n=119$ trials), and male C57 entry ( $\mathrm{n}=108$ trials).

(D) Possibilities of behavior trials showing attack during diverse stimuli as shown in (B) and (C).

(E) Setup for fiber photometric recording in $\mathrm{pSI}^{\text {Thy1 }}$ neurons in response to diverse non-social 1188 and social stimuli.

1189 (F) Distribution of episodes of behavior and heatmaps of GCaMP6m $\Delta F / F$ signals from pSI neurons during water consumption (upper, $\mathrm{n}=52$ trials), food consumption (middle, $\mathrm{n}=260$ trials), and approach a cotton ball (lower, $\mathrm{n}=23$ trials). neurons during detection of DMSO (upper, $n=30$ trials), urine (middle, $n=36$ trials), and TMT (lower, $\mathrm{n}=57$ trials) by approach.

(H) Distribution of episodes of behavior and heatmaps of GCaMP6m $\Delta F / F$ signals from $\mathrm{pSI}$ neurons in response to air puff (upper, $n=40$ trials), the threat of a flying glove (middle, $n=40$ trials), and tail suspension (lower, $\mathrm{n}=40$ trials). above each bar indicate that AUC per second (left) or peak $\Delta F / F$ (right) during each behavior period was $(P<0.05)$ and wasn't $(P>0.05)$ significantly increased compared with baseline prebehavior, determined by Wilcoxon matched-pairs signed-rank test and two-tailed paired t-test. $(\mathrm{J}-\mathrm{N})$ Distribution of episodes of behavior, heatmaps of GCaMP6m $\Delta F / F$ signals, and $\Delta F / F$ of GCaMP6m (magenta) signals from pSI neurons with object entry $(\mathrm{J}, \mathrm{n}=53$ trials in female entry ( $\mathrm{K}, \mathrm{n}=39$ trials), male C57 entry ( $\mathrm{L}, \mathrm{n}=39$ trials), male $\mathrm{CD}-1$ entry ( $\mathrm{M}, \mathrm{n}=58$ trials $)$, and male C57 entry preceding an attack $(\mathrm{N}, \mathrm{n}=28$ trials $)$. 
1211 unpaired t-test, and paired t-test: from left to right, $* * P=0.005$, *** $P<0.001, * * P=0.004, * P$

$1212=0.0131$. Significance of differences in the AUC/s was determined by the Mann-Whitney and 1213 Kruskal-Wallis tests, unpaired t-test, and paired t-test: from left to right, $* * P=0.007, * * P=$ $1214 \quad 0.0083, * * * P<0.001, * P=0.0239$.

1215 ns, not significant.

1216 Data are presented as the mean \pm SEM. 
1217 Figure S5. Anterograde Virus Tracing of the pSI-PAG Connection, and Pharmacogenetic

1220 (A) Schematic for injection of anterograde trans-synaptic virus into the pSI to trace pSI-PAG 1221 connections in Ai14 male mice.

1222 (B) Representative images of pSI (left) and VL/LPAG (right) neurons infected with anterograde 1223 trans-synaptic AAV1-CMV-Cre Tdtomato (scale bars, $50 \mu \mathrm{m}$ ).

1224 (C) Schematic of the strategy for anterograde virus tracing.

1225 (D) Representative images showing the expression of trans-synaptic anterograde AAV1-CMV1226 Cre and AAV-DIO-mCherry (red) in the pSI (left, scale bar, $50 \mu \mathrm{m}$ ) and the VL/LPAG (right, 1227 scale bar, $100 \mu \mathrm{m})$. Aq, aqueduct; DRL, dorsal raphe nucleus, lateral part. (E) Schematic showing injection of retrograde tracing virus into the PAG and immunostaining/imaging of $\mathrm{pSI}^{-\mathrm{PAG}}$ neurons. staining for DAPI (blue) and CaMKII $\alpha$ (left, red) or GAD67 (right, red). Scale bars, $50 \mu \mathrm{m}$. (G) Left panels, example images showing the overlap of retrogradely-labeled $\mathrm{pSI}^{-\mathrm{PAG}}$ neurons (green) with staining for Thy1 (red). Scale bars, $100 \mu \mathrm{m}$. Right panels, magnified images of the boxed areas in the left panels; Scale bars, $10 \mu \mathrm{m}$. Arrowheads indicate retrogradely-labeled neurons co-localized with mCherry.

(H) Percentage overlap of EGFP-expressing neurons with Thy1, CaMKII $\alpha$ or GAD67 (KW = 11.65, $* * * P<0.001$; Kruskal-Wallis test, $\mathrm{n}=5 / 5 / 6$ mice).

(I) Schematic of the strategy for retrograde tracing from the PAG and Cre-dependent pharmacogenetic activation of $\mathrm{pSI}^{-\mathrm{PAG}}$ neurons.

(J) Left, overlay of EGFP and mCherry expression from mice unilaterally injected with retrograde AAV-Retro-Cre-EGFP virus into the PAG and anterograde AAV-DIO-mCherry virus into the pSI. Right, overlay of EGFP and hM3D-mCherry expression from mice unilaterally injected with retrograde AAV-Retro-Cre-EGFP virus into the PAG and anterograde AAV-DIOhM3D-mCherry virus into the pSI. EGFP (green) and mCherry terminals (red) projected from the pSI (scale bar, $100 \mu \mathrm{m}$ ). neurons in slice preparations. Lower, sample recording trace from an hM3D-expressing pSI neuron in response to perfusion with CNO. 
1251 CNO.

1252 (N) Middle, schematic showing unilateral injection of hM3Dq-mCherry virus into the pSI. Left, 1253 representative histological image showing c-Fos expression (yellow) on the uninjected side. 1254 Right, representative histological image of c-Fos expression on the side of the pSI injected with $1255 \mathrm{hM} 3 \mathrm{Dq}-\mathrm{mCherry}$ virus (red). Scale bars, $100 \mu \mathrm{m}$.

1256 (O) High-magnification images of the boxed area in (N) (scale bar, $10 \mu \mathrm{m}$; arrowheads indicate 1257 pSI neurons immunopositive for c-Fos antibody).

1258 (P) Behavioral paradigm of aggression test.

1259 (Q) Raster plots of attack behavior recorded during 15-min encounters.

1260 (R) Summary of aggression during the pre- and post-injection phases in the control and hM3Dq 1261 groups ( $\mathrm{n}=7 / 10$ mice) with saline or CNO injection. Red blocks indicate duration of attack 1262 episodes. Pre-CNO vs $\mathrm{CNO}$ in the hM3D group: from left to right, $* * P=0.002, * * P=0.002$, $1263 * * P=0.002$; saline $v s \mathrm{CNO}$ in the hM3D group: from left to right, $* * P=0.002, * * P=0.002$, $1264 * * P=0.002$, Wilcoxon matched-pairs signed-rank test.

1265 (S) Raster plots of attack behavior recorded during 15-min encounters.

1266 ns, not significant.

1267 Data are presented as the mean \pm SEM. 
(A) Strategy for virus injection and photoactivation of $\mathrm{pSI}^{-\mathrm{PAG}}$ neurons in male mice.

(B) Schematics and representative images of AAV-Retro-Cre-EGFP expression in the PAG (left, scale bar, $100 \mu \mathrm{m}$ ) and AAV-DIO-ChR2-EYFP expression in upstream pSI neurons (right, scale bars, $50 \mu \mathrm{m})$.

(C) Left, overlay of EGFP expression from mice unilaterally injected with retrograde AAVoverlay of EGFP and ChR2-EGFP expression from mice unilaterally injected with retrograde AAV-Retro-Cre-EGFP virus into the PAG and anterograde AAV-DIO-ChR2-EGFP virus into the pSI.

(D) Left, schematic of whole-cell recordings from ChR2-expressing $\mathrm{pSI}^{-\mathrm{PAG}}$ neurons in slice preparations. Middle, the light-induced inward current recorded in a ChR2+ pSI neuron (blue bar, application of a LED-generated blue light pulse). Right, action potentials recorded from a ChR2expressing pSI neuron induced by $5,10,20$, and $40 \mathrm{~Hz}$ light stimulation.

(E) Behavioral paradigm of inter-male aggression test.

(F) Success rates of light-induced attacks in response to different frequencies of light stimulation at a fixed intensity $(2.7 \mathrm{~mW}) .5 \mathrm{~Hz} v s 10 \mathrm{~Hz} v s 20 \mathrm{~Hz}$ vs $40 \mathrm{~Hz}$ in the ChR2 group: $0.0 \pm 0.0$ vs $6.7 \pm 3.3$ vs $34.4 \pm 11.7$ vs $90.0 \pm 6.7(\%)$, ***P $<0.001, \mathrm{n}=9$ trials, Friedman test. light onset in the laser or sham stimulation group $(n=9 / 8$ mice). Right, relative pupil size before, during, and after photostimulation $(* * * P<0.001, \mathrm{n}=9$ mice, Friedman test). after photostimulation of $\mathrm{pSI}^{-\mathrm{PAG}}$ neurons (Friedman test, $\mathrm{FM}=0.7429, P=0.7407, \mathrm{n}=9$ mice). photostimulation of $\mathrm{pSI}^{-\mathrm{PAG}}$ neurons (one-way ANOVA, F $(1.608,12.87)=0.2183, P=0.7599, \mathrm{n}$ $1296=9$ mice).

$1297(\mathrm{~K})$ Behavioral paradigm of open field test with photoactivation of $\mathrm{pSI}^{-\mathrm{PAG}}$ neurons in socially1298 housed male C57 mice ( $\mathrm{n}=6$ mice), with a shield cover (nest) inside the open field box.

1299 (L-N) Latency to the nest (L, $P=0.0721$, Friedman test), averaged velocity in each 1300 photostimulation period ( $\mathrm{M}$, from $-15 \mathrm{~s}$ to $30 \mathrm{~s}$ ), and velocity in the pre (1), during (2), and post1301 laser (3) period (N, $P=0.3379$, one-way ANOVA).

1302 (O) Averaged velocity during period 1,2 , and 3 ( $P=0.0875$, one-way ANOVA).

1303 (P) Schematic of the timing and behavioral paradigm with optical activation of $\mathrm{pSI}^{\mathrm{CaMKII} \alpha}$ 
1304 neurons in male mice.

1305 (Q) Left, schematic of pSI injection of virus-carrying AAV-CaMKII $\alpha$-ChR2-mCherry or AAV1306 CaMKII $\alpha$-mCherry and light stimulation of pSI ${ }^{\text {CaMKII } \alpha}$ neurons. Right, representative histological 1307 images of light-induced c-Fos expression (green) in neurons expressing AAV-CaMKII $\alpha$-ChR2-

1308 mCherry (magenta). Arrowheads indicate neurons co-expressing AAV-CaMKII $\alpha$-ChR2-mCherry 1309 and c-Fos.

1310 (R) Overlay of CaMKII $\alpha$-ChR2-mCherry expression in pSI (-1.06 mm from bregma).

1311 (S) Behavioral paradigm of a socially-housed male mouse in its home cage attacking a singly1312 housed male intruder.

1313 (T) Percentage of trials with attacks, total latency to attack, attack duration, and number of 1314 attack events in response to pSI photostimulation in the ChR2 group and controls (mCherry 1315 group) (Wilcoxon matched-pairs signed-rank test and two-tailed unpaired t-test: from left to right, $1316 * * * P<0.001, * * * P<0.001, * P=0.0313$, *** $P<0.001, \mathrm{n}=15 / 6$ mice) during the pre-laser, 1317 laser, and post-laser phases when a socially-housed male mouse initiated an attack in its home 1318 cage on a singly-housed male intruder (Friedman test: from left to right, $* * * P<0.001$, *** $P<$ $13190.001, * * * P<0.001, * * * P<0.001, \mathrm{n}=15$ mice $).$

1320 ns, not significant.

1321 Data are presented as the mean \pm SEM. 
1322 Figure S7. Optogenetic Activation of pSI ${ }^{\text {Thy } 1}$ Neurons Projecting to the PAG Promotes Inter-male Aggression, Related to Figure 4

(A, B) Experimental design: (A) photostimulation of $\mathrm{pSI}^{\mathrm{Thy} 1}$ neurons projecting to the PAG and (B) schematic of the injection strategy of virus and CTB555. (red) in the PAG (scale bar, $100 \mu \mathrm{m}$ ); Aq, aqueduct; DRL, dorsal raphe nucleus, lateral part; MeA, medial amygdaloid nucleus; CeM, central amygdaloid nucleus, medial division. Right, representative image of FDIO-ChR2-EYFP (green) and ChAT (yellow) in the pSI (scale bar, 100 $\mu \mathrm{m})$. Insets, magnified images of the boxed areas in the right panels; scale bar, $10 \mu \mathrm{m}$. photoactivation of $\mathrm{pSI}^{\text {Thy1 }}$ projection terminals in the VL/LPAG.

(E) Representative traces of the light-evoked currents in the PAG neurons by photostimulating axonal projections from the pSI to VL/LPAG neurons in the absence or presence of the GABA receptor antagonist Picrotoxin and the glutamate receptor antagonist CNQX; Vh, holding voltage. 0.0006, $\mathrm{n}=4 / 5$ neurons).

(G) Proportions of PAG neurons $(\mathrm{n}=57)$ showing light-evoked excitatory and inhibitory postsynaptic currents by photostimulating axonal projections from the pSI. encounters a socially-housed male C57 mouse in its home cage.

1343 (I) Distribution of attack episodes during photostimulation.

1344 (J) Summary of male aggression induced by photostimulation of $\mathrm{pSI}^{\text {Thy1 }}$ neurons projecting to 1345 the PAG: percentage of trials showing attacks $(* * P=0.0031)$, latency to attack onset $(* * P=$ $0.0031)$, attack duration $(* * P=0.0031)$, and attack events $(* * P=0.0031)$ in pre-laser, laser, and post-laser phases. $\mathrm{n}=5$ mice, Friedman test. encounters crickets in its home cage. 
1358 (A) Upper left, schematic of pSI injection of virus-carrying AAV-CaMKII $\alpha$-ChR2-mCherry and optical activation of $\mathrm{pSI}^{\mathrm{CaMKII} \alpha}$ neurons. Upper right, schematic of the timing and behavioral paradigm with optical activation of $\mathrm{pSI}^{\mathrm{CaMKII} \alpha}$ neurons in male or female mice. Lower, overlay of CaMKII $\alpha$-ChR2-mCherry expression in the pSI (-1.06 mm from bregma) of female mice. (B) Behavioral paradigm of a socially-housed mouse in its home cage attacking a singly-housed intruder induced by optical activation of $\mathrm{pSI}^{\mathrm{CaMKII} \alpha}$ neurons. with photostimulation of $\mathrm{pSI}^{\mathrm{CaMKII} \alpha}$ neurons in the pre-laser, laser, and post-laser phases. A socially-housed male mouse in its home cage initiated an attack on a socially-housed female intruder $(\mathrm{C}$, from left to right, $* * * P<0.001, * * * P<0.001, * * P=0.0092, * * P=0.0022, \mathrm{n}=6$ mice), and a socially-housed female in its home cage initiated an attack on a socially-housed male ( $\mathrm{D}$, from left to right, $* * * P<0.001, * * * P<0.001, * * P=0.0046, * * P=0.0047, \mathrm{n}=6$ mice) or female intruder (E, from left to right, $* P=0.0168, * * * P<0.001, * * P=0.005, * * P=0.0063$, $\mathrm{n}=5$ mice). Significance was determined by one-way ANOVA.

1372 (F) Upper, schematic of the timing and behavioral paradigm with pharmacogenetic activation of $\mathrm{pSI}^{\text {Thy1 }}$ neurons through Cre-dependent expression of AAV-DIO-hM3d-mCherry in Thy1-Cre male and female mice. Lower, overlay of hM3d-mCherry expression in pSI (-1.06 $\mathrm{mm}$ from bregma) of the female Thy1-Cre mice. socially-housed Thy1-Cre male mouse in a novel cage promoted attacks on a socially-housed female.

1379 (H-J) Latency to attack, attack duration, and attack events during the pre- and post-injection 1380 phases of the pharmacogenetic activation of $\mathrm{pSI}^{\text {Thy1 }}$ neurons. A socially-housed male mouse 1381 encountered a socially-housed female $(\mathrm{H}$, from left to right, $* P=0.0313, * * * P<0.001$, ** $P=$ $0.001, \mathrm{n}=6$ mice) and a socially-housed female encountered a socially-housed male (I, from left to right, $* * * P<0.001, * P=0.0176, * P=0.0264, \mathrm{n}=5$ mice) or female ( $\mathrm{J}$, from left to right, $P=$ $0.0625, * P=0.0378, P=0.0625, \mathrm{n}=5$ mice) in a novel cage. Significance was determined by the Wilcoxon matched-pairs signed-rank test and two-tailed paired t-test. ns, not significant. 


\section{Figure S9. Parallel Output Connections of pSI ${ }^{-P A G}$ Neurons, Related to Figure 5}

1389 (A) Strategy of anterograde tracing of $\mathrm{pSI}^{-\mathrm{PAG}}$ neurons.

1390 (B) Horizontal section series showing the brain-wide distribution of the output connected 1391 neurons with $\mathrm{pSI}^{-\mathrm{PAG}}$ neurons revealled by anterograde transsynaptic tracing experiments. Green, 1392 EGFP; magenta, mCherry from mRuby.

1393 (C) Overview of the outputs from the $\mathrm{pSI}^{-\mathrm{PAG}}$ neurons as shown in (B). 


\section{Figure S10. The Projection from pSI ${ }^{\text {CaMKII }}$ Neurons to the PAG, but not to the BNST or}

\section{VMH, Universally Drove Diverse Aggressive Behaviors, Related to Figure 5}

(A) Strategy for virus injection and optical activation of the terminals of $\mathrm{pSI}^{-\mathrm{PAG}}$ neurons in the PAG and BNST in male mice. neurons (right; scale bar, $100 \mu \mathrm{m}$ ).

(C) Behavioral paradigm of the attack test of a socially-housed male in its home cage towards a singly-housed male intruder.

(D) Upper, schematic of c-Fos examination of PAG neural activation induced by light stimulation of $\mathrm{pSI}^{-\mathrm{PAG}}$ terminals in male mice. Lower, representative histological images of the PAG stained with c-Fos (red) after photostimulation of pSI $^{-\mathrm{PAG}}$ terminals expressing ChR2-EGFP (green) on the stimulated and unstimulated sides (scale bars, $50 \mu \mathrm{m}$ ).

(E) Left, percentage of animals showing attacks by photostimulation of the pSI-BNST, pSI-VMH, and pSI-PAG projection in male mice. Right, distribution of attack episodes during photostimulation of the pSI-PAG projection (magenta, ChR2 group; gray, EYFP group; $\mathrm{n}=5$ mice).

(F) Percentage of trials, latency to attack, attack duration, and attack events in the photostimulation (ChR2) and control (EYFP) groups during the pre-laser, laser, and post-laser phases. Pre $v s$ Laser vs Post in the ChR2 group: $P=0.123$, *** $P<0.001, * P=0.0271, P=0.123$, one-way ANOVA or Friedman test, $\mathrm{n}=5$ mice; Laser in EYFP and the ChR2 group: $* * P=$ $0.0022, * * * P<0.001, * * P=0.0044$, $* * P=0.0022$, two-tailed unpaired t-test and MannWhitney test, $\mathrm{n}=5 / 6$ mice.

(G) Schematic of the behavioral design to test various forms of aggression induced by photostimulation of $\mathrm{pSI}^{-\mathrm{PAG}}$ projection terminals in the PAG under various conditions. $(\mathrm{H}-\mathrm{K})$ Aggression probability $(\mathrm{H})$, latency to attack onset $(\mathrm{I})$, duration $(\mathrm{J})$, and events $(\mathrm{K})$ of various forms of aggression induced by photostimulation of $\mathrm{pSI}^{-\mathrm{PAG}}$ projection terminals in the PAG. '(E)' and ' $(\mathrm{N})$ ' under the $\mathrm{x}$-axis indicate that the aggression during photostimulation was significantly increased $(\mathrm{E})$ or not changed $(\mathrm{N})$, determined by one-way ANOVA or the Friedman test. 'NT' under the $\mathrm{x}$-axis indicates that this index of aggression was not tested under this condition. neurons and optogenetic activation of the terminals of $\mathrm{pSI}^{\mathrm{CaMKII} \alpha}$ neurons projecting to the PAG or BNST. Middle, schematic and example images of c-Fos expression (green) in the PAG induced by local light stimulation of $\mathrm{pSI}^{\mathrm{CaMKII} \alpha}$ neuronal terminals in the PAG. Right, example 
1429 image of $\mathrm{pSI}^{\mathrm{CaMKII} \alpha}$ neuronal terminals in the BNST.

1430 (M) Schematic of the timing and behavioral paradigm with optical activation of $\mathrm{pSI}^{\mathrm{CaMKII} \alpha}$ 1431 neuron terminals in a socially-housed mouse in its home cage encountering a male intruder.

1432 (N) Behavioral paradigm of a socially-housed mouse in its home cage attacking a singly-housed 1433 intruder induced by optical activation of $\mathrm{pSI}^{\mathrm{CaMKII} \alpha}$ neuronal terminals.

1434 (O) Summary data showing attacks were induced by optogenetic activation of $\mathrm{pSI}^{\mathrm{CaMKII} \alpha}$ 1435 terminals in the PAG but not in the BNST in socially-housed male mice.

1436 (P) Summary data showing socially-housed male mice in their home cages initiated attacks on 1437 singly-housed male intruders during optical activation of the $\mathrm{pSI}^{\mathrm{CaMKII} \alpha}$-PAG projection. 1438 Percentage of trials with attacks, latency to attack, attack duration, and attack events induced by 1439 optogenetics during the pre-laser, laser, and post-laser phases in the control mCherry group $(\mathrm{n}=$ 14406 mice) and in the ChR2 group ( $\mathrm{n}=8$ mice). Pre $v s$ Laser $v s$ Post in the ChR2 group: ***P< $14410.001, * * * P<0.001, * * * P<0.001$, $* * * P<0.001$, Friedman test, $\mathrm{n}=8$ mice; Laser in the 1442 mCherry and ChR2 groups: $* * * P<0.001, * * * P<0.001$, *** $P<0.001$, *** $P<0.001$, two1443 tailed unpaired t-test, $n=6 / 8$ mice. Significance was determined by the Friedman test and 1444 unpaired t-test.

1445 (Q) Summary data showing socially-housed female mice in their home cages initiated attacks on 1446 singly-housed male intruders during optical activation of the $\mathrm{pSI}^{\text {CaMKII }}$-PAG projection $(* * P=$ $14470.007, * * P=0.0056,{ }^{*} P=0.0451, * P=0.0182, \mathrm{n}=3$ mice, significance determined by one-way 1448 ANOVA).

1449 (R) Overlays of CaMKII $\alpha$-ChR2-mCherry (left) and CaMKII $\alpha$-mCherry (middle) expression in 1450 pSI in male mice, Right, overlay of CaMKII $\alpha$-ChR2-mCherry expression in pSI of female mice. 1451 ns, not significant.

1452 Data are presented as the mean \pm SEM. 


\section{Figure S11. Inputs of pSI-PAG Neurons, Related to Figure 6}

1454 (A) Strategy of retrograde transsynaptic tracing of $\mathrm{pSI}^{-\mathrm{PAG}}$ neurons.

1455 (B) Horizontal section series showing the brain-wide distribution of inputs to pSI $^{-P A G}$ neurons

1456 revealed by the retrograde transsynaptic tracing experiments. Green, EGFP; magenta, mCherry

1457 from RVdG.

1458 (C) Overview of the inputs into the $\mathrm{pSI}^{-\mathrm{PAG}}$ neurons as shown in (B). Right is the quantification

1459 of inputs to $\mathrm{pSI}^{\mathrm{PAG}}$ neurons, Data are shown as the percentage of inputs from a given region

1460 relative to total inputs throughout a given brain $(n=3$ mice $)$. Heat map coloration corresponds to

1461 the percentage of total labeling. 
Figure S12. Effect of ASD on the Aggressive Activity Triggered by Photostimulation of pSIPAG Neurons, Related to Figure 6

1464 (A) Strategy for virus injection and optical activation of $\mathrm{pSI}^{-\mathrm{PAG}}$ neurons in male mice.

1465 (B) Schematic for testing inter-male aggression induced by different stimulation intensities 1466 before and after ASD.

1467 (C) Behavioral paradigm of inter-male aggression during photoactivation of $\mathrm{pSI}^{-\mathrm{PAG}}$ neurons at 1468 different stimulation intensities before and after ASD.

1469 (D-G) Nonlinear regression of the probability of trials showing attack (D), latency to attack onset $1470(\mathrm{E})$, duration $(\mathrm{F})$, and events $(\mathrm{G})$ of the inter-male aggression triggered by photoactivation of $\mathrm{pSI}^{-}$

1471 PAG neurons at different intensities. Different colored lines are non-linear fits before and after 1472 ASD (pooled across all mice and binned light intensities).

$1473(\mathrm{H}-\mathrm{K})$ Probability of trials showing attack $(\mathrm{H})$, latency to attack onset $(\mathrm{I})$, duration $(\mathrm{J})$ and events $1474(\mathrm{~K})$ of the inter-male aggression induced during laser stimulation with a specific laser intensity $1475(1.51 \mathrm{~mW})$ before and after ASD $(\mathrm{n}=3$ mice). Before ASD vs After ASD: from left to right, $* P$ $1476=0.0306, * * P=0.0045, * * P=0.0022, P=0.2500$, two-tailed paired $\mathrm{t}$-test and Wilcoxon 1477 matched-pairs signed-rank test.

1478 ns, not significant.

1479 Data are presented as the mean \pm SEM. 


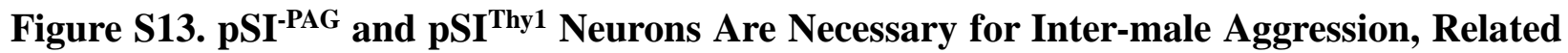

\section{to Figure 7}

(A) Schematic of the expression of AAV-Retro-Cre-EGFP in the PAG to drive Cre-dependent expression of AAV-DIO-hM4Di-mCherry in $\mathrm{pSI}^{-\mathrm{PAG}}$ neurons.

(B) Left, schematic and representative image showing the expression of retrograde AAV-RetroCre-EGFP (green) in the PAG (scale bar, $100 \mu \mathrm{m}$ ). Right, schematic and representative image showing Cre-dependent expression of AAV-DIO-hM4Di-mCherry (red) in pSI $^{-P A G}$ neurons infected with AAV-Retro-Cre-EGFP (green, arrowheads) (scale bars, $100 \mu \mathrm{m}$; inset, $10 \mu \mathrm{m}$ ). (C) Schematic of the timing (upper) and behavioral paradigm (lower) for pharmacogenetic inhibition of $\mathrm{pSI}^{\mathrm{PAG}}$ neurons of a singly-housed male mouse in its home cage encountering a socially-housed male intruder (lower).

(D) Example raster plots of behavioral recordings from mice during 15-min encounters in the control group (mCherry, $n=6$ mice) and the hM4Di group ( $=8$ mice) (red marks, episodes of aggression).

(E) Latency to attack (left), attack duration (middle), and attack events (right) during the preand post-injection phases in control and hM4Di groups after saline or CNO injection. Latency, W $=13.00, * * P<0.01$; duration, $\mathrm{W}=-36.00, * * P<0.01$; and events, $\mathrm{W}=-36.00, * * P<0.01$ in the hM4Di group (Wilcoxon matched-pairs signed-rank test and two-tailed paired t-test, $\mathrm{n}=8$ mice).

(F) Overlays of EGFP and mCherry expression from mice bilaterally injected with retrograde AAV-Retro-Cre-EGFP virus into the PAG and anterograde AAV-DIO-mCherry virus into the pSI. (G) Overlays of EGFP and hM4D-mCherry expression from mice bilaterally injected with retrograde AAV-Retro-Cre-EGFP virus into the PAG and anterograde AAV-DIO-hM4D-mCherry virus into the $\mathrm{pSI}$.

(H) Left, representative whole-cell current clamp recordings from a pSI neuron (upper) in response to intracellular current injection of a pulse train from $0 \mathrm{pA}$ to $120 \mathrm{pA}$ in a step of $20 \mathrm{pA}$ (lower) before, during, and after $5 \mu \mathrm{M}$ CNO perfusion. Right, red traces indicate the minimal current to induce action potentials.

(I) Summarized response curves showing the number of induced action potentials at different injected current steps in the $\mathrm{CNO}$ and control group. Paired t-test, $* * P=0.003, \mathrm{n}=8$ neurons. test, $* * P=0.002, \mathrm{n}=8$ neurons. with AAV-DIO-mCherry and AAV-DIO-hM4D-mCherry virus bilaterally injected into the pSI. 
bioRxiv preprint doi: https://doi.org/10.1101/2020.04.22.047670; this version posted February 19, 2021. The copyright holder for this preprint (which was not certified by peer review) is the author/funder, who has granted bioRxiv a license to display the preprint in perpetuity. It is made available under aCC-BY-NC-ND 4.0 International license.

1516 during 15-min encounters.

1517 ns, not significant.

1518 Data are presented as the mean \pm SEM. 
1519 Figure S14. Inactivation of pSI $^{\text {Thy1 }}$ Neurons Interrupts Female-male and Male-female

1520

1521

1522

1523

1524

1525

1526

1527

1528

1529

1530

1531

1532

1533

1534

1535

1536

1537

1538

1539

1540

1541

1542

1543

1544

1545

1546

1547

1548

1549

1550

1551 Aggression, Related to Figure 7
(A) Schematic of bilateral injection of DIO-GtACR1-GFP virus into the pSI of male and female Thy1-Cre mice.

(B) Left, example image showing the expression of DIO-GtACR1-GFP in pSI $^{\text {Thy1 }}$ neurons (scale bar, $50 \mu \mathrm{m}$ ). Right, light-induced inhibition of action potentials (upper green trace) evoked by intracellular current injection (lower black trace) in a GtACR1-expressing pSI $^{\text {Thy1 }}$ neuron (blue bar, application of a LED-generated blue light pulse; $\mathrm{n}=8$ neurons).

(C, D) Upper, behavioral paradigms to assess the effects of optogenetic inhibition of $\mathrm{pSI}^{\text {Thy1 }}$ neurons on male-female aggression (C) and female-male aggression (D). Lower, example raster plots showing the time-locked interruption of these two types of aggressive behaviors by optogenetic inhibition of $\mathrm{pSI}^{\mathrm{Thy} 1}$ neurons.

(E) Distribution of attack episodes interrupted by optogenetic inhibition of $\mathrm{pSI}^{\text {Thy } 1}$ neurons in male-female aggression $(\mathrm{n}=6$ mice).

(F) Attack duration in the pre-laser, laser, and post-laser phases by optogenetic inhibition of aggressive behavior; $* * P=0.0038$.

(G) Distribution of attack episodes interrupted by optogenetic inhibition of $\mathrm{pSI}^{\text {Thy1 }}$ neurons in female-male aggression $(\mathrm{n}=4$ lactating adult female mice).

(H) Attack duration in the pre-laser, laser, and post-laser phases by optogenetic inhibition of aggressive behavior; $* P=0.0417$.

(I) Behavioral paradigm to test the effect of optogenetic inhibition of $\mathrm{pSI}^{\text {Thy1 }}$ neurons on general locomotion in the open field test (OFT).

$(\mathrm{J}, \mathrm{K})$ Inhibition of $\mathrm{pSI}^{\text {Thy1 }}$ neurons has no effect on the distance traveled $(\mathrm{J})$ and velocity $(\mathrm{K})$ of locomotor activity in the open field ( $\mathrm{n}=3 / 8$ mice). EYFP vs Laser: $P=0.1167$.

(L) Behavioral paradigm for assessing feeding behavior in response to optogenetic inhibition of $\mathrm{pSI}^{\text {Thy1 }}$ neurons.

(M-P) Latency to feeding offset (M), probability of feeding trials interrupted within $3 \mathrm{~s}(\mathrm{~N})$, duration of feeding $(\mathrm{O})$, and feeding events $(\mathrm{P})$ of the feeding behavior before, during, and after optical silencing of $\mathrm{pSI}^{\text {Thy1 }}$ neurons with a laser intensity the same as that inhibiting attacks $(\mathrm{n}=$ 8/8 mice). Sham $v s$ Laser: from left to right, $P=0.0621, P=0.0621, P=0.0719, P=0.6094$.

ns, not significant.

Data are presented as the mean \pm SEM. 


\section{Supplemental Movies S1-S5}

Movie S1. Optogenetic activation of pSI $^{-\mathrm{PAG}}$ neurons in a $\mathrm{C} 57$ male mouse in its home cage evokes attacks on a singly-housed male intruder, Related to Figure 4.

The male mouse (black) transfected with $\mathrm{ChR} 2$ in $\mathrm{pSI}^{-\mathrm{PAG}}$ neurons and implanted with a fiberoptic cable in the pSI was photostimulated during the period indicated by "Light on".

Movie S2. Optogenetic activation of pSI $^{-\mathrm{PAG}}$ neurons evokes arousal responses, including an enlarged pupil in a head-fixed C57 male mouse, Related to Figure 4.

The male mouse (black) transfected with $\mathrm{ChR} 2$ in $\mathrm{pSI}^{-\mathrm{PAG}}$ neurons and implanted with a fiberoptic cable in the pSI was photostimulated during the period indicated by "Light on".

Movie S3. Optogenetic activation of pSI $^{-\mathrm{PAG}}$ neurons in a $\mathrm{C57}$ female mouse in its home cage evokes attack on a socially-housed male intruder, Related to Figure 5.

The female mouse (black) transfected with $\mathrm{ChR} 2$ in $\mathrm{pSI}^{-\mathrm{PAG}}$ neurons and implanted with a fiber-optic cable in pSI was photostimulated during the period indicated by "Light on".

Movie S4. Optogenetic activation of PSI $^{-P A G}$ neurons in a C57 male mouse evokes defensive attack on a male CD-1 mouse in the latter's cage, Related to Figure 5.

The male mouse (black) transfected with $\mathrm{ChR} 2$ in $\mathrm{pSI}^{-\mathrm{PAG}}$ neurons and implanted with a fiberoptic cable in pSI was photostimulated during the period indicated by "Light on".

Movie S5. Optogenetic silencing of $\mathrm{pSI}^{\text {Thy1 }}$ neurons in a male Thy1-Cre mouse interrupts a naturally-occurring attack on a socially-housed mouse in a time-locked manner, Related to Figure 7.

The Thy1-Cre male mouse (white) transfected with GtACR1 in pSI ${ }^{\text {Thy1 }}$ neurons and implanted with a fiber-optic cable in pSI was photostimulated during the period indicated by "Light on". 
bioRxiv preprint doi: https://doi.org/10.1101/2020.04.22.047670; this version posted February 19, 2021. The copyright holder for this preprint (which was not certified by peer review) is the author/funder, who has granted bioRxiv a license to display the preprint in perpetuity. It is made available under aCC-BY-NC-ND 4.0 International license.

\section{Figures S1-S14}

\section{Figure S1}

A

Blue brain mouse cell atlas

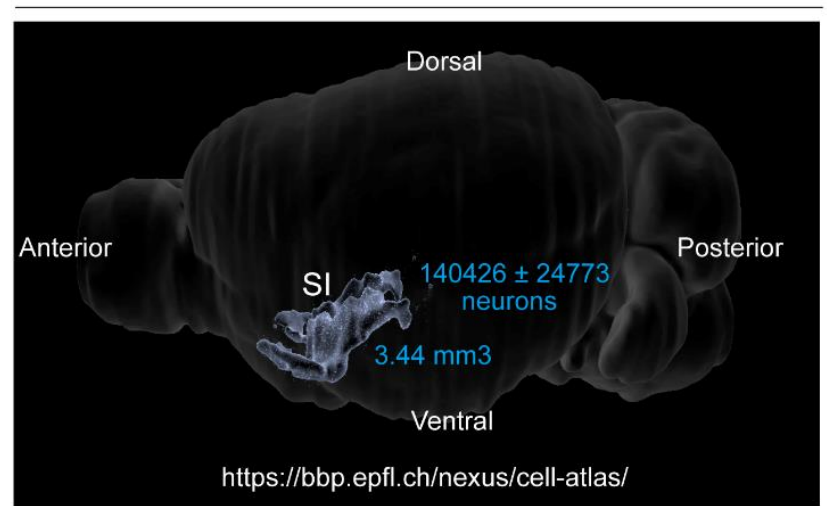

B

Allen mouse brain atlas

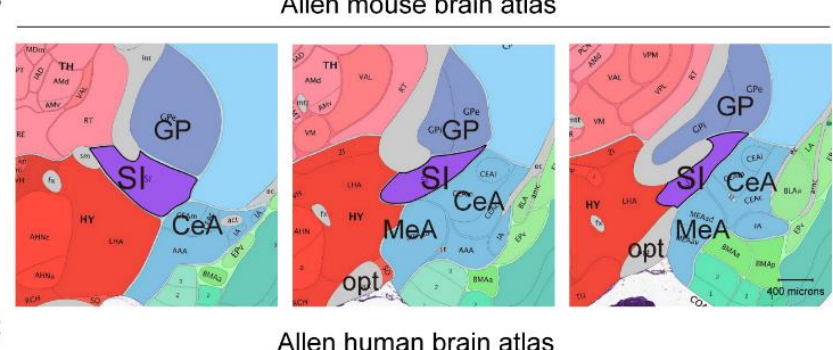

C

Allen human brain atlas

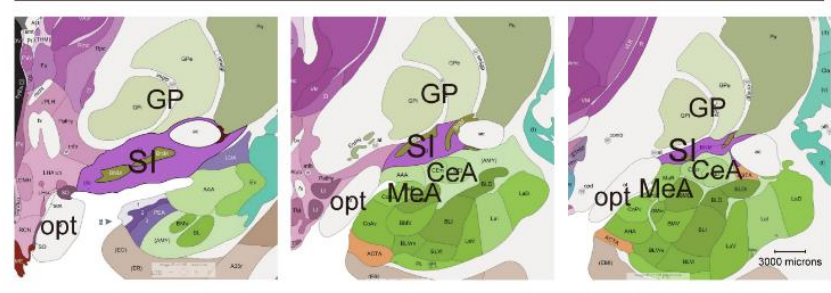


bioRxiv preprint doi: https://doi org/10.1101/2020.04.22 047670; this version posted February 19,2021 . The copyright holder for this preprint (which was not certified by peer review) is the author/funder, who has granted bioRxiv a license to display the preprint in perpetuity. It is made available under aCC-BY-NC-ND 4.0 International license.

\section{Figure S2}

A

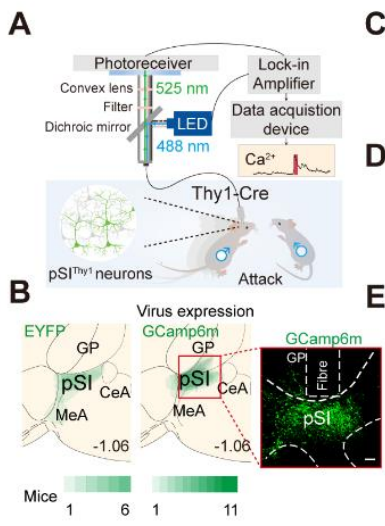

K

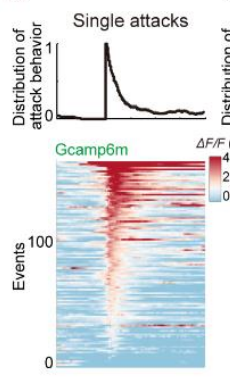

Time window of activation

$$
\text { - Pre -Attack - Post }
$$

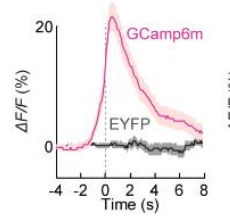

L

First attacks

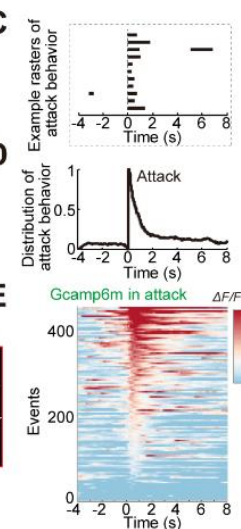

M

¿... Last attacks
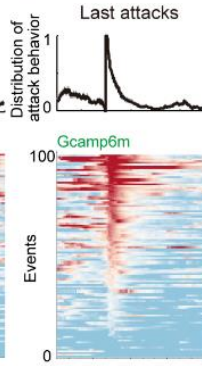

Time window of activation
-Pre -Attack - Post
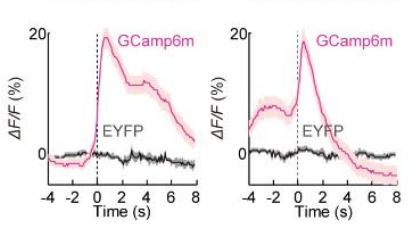

F

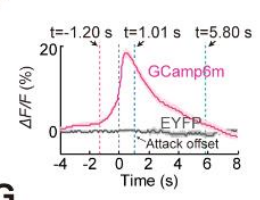

G

Time window of neural activation -Pre-attack -Attack - Post-attack

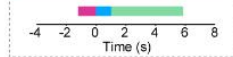

H -Pre-attack -Attack - Post-attack

I

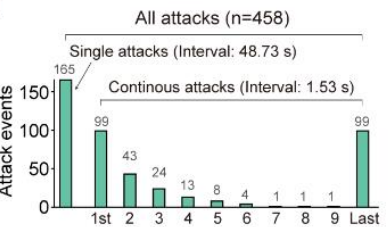

J Activity in example attack episodes

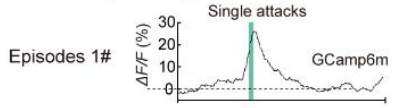

Episodes 2\# Continous attacks $\quad \frac{- \text { Atack }}{23}$

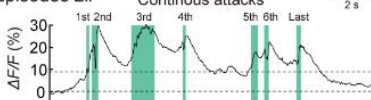

N

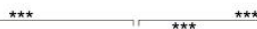

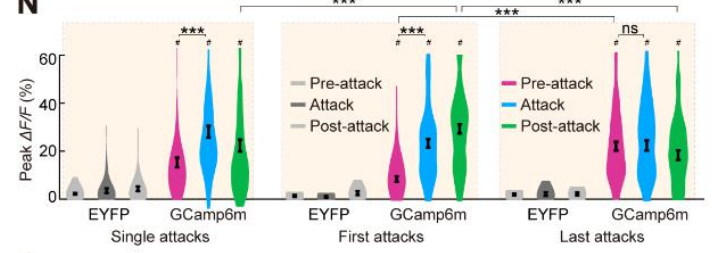

o
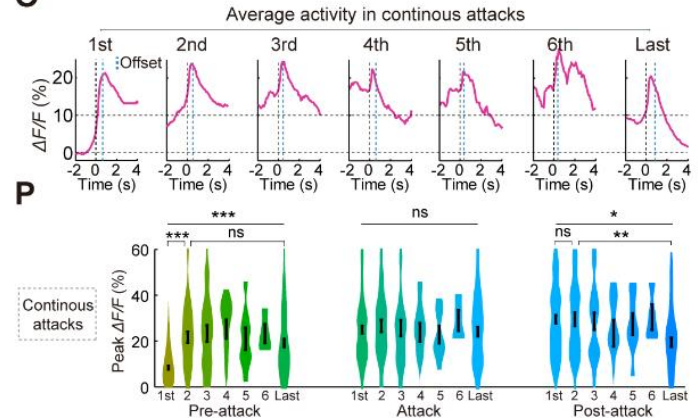
bioRxiv preprint doi: https://doi org/10.1101/2020.04.22 047670; this version posted February 19. 2021. The copyright holder for this preprint (which was not certified by peer review) is the author/funder, who has granted bioRxiv a license to display the preprint in perpetuity. It is made available under aCC-BY-NC-ND 4.0 International license.

\section{Figure S3}

\section{A}
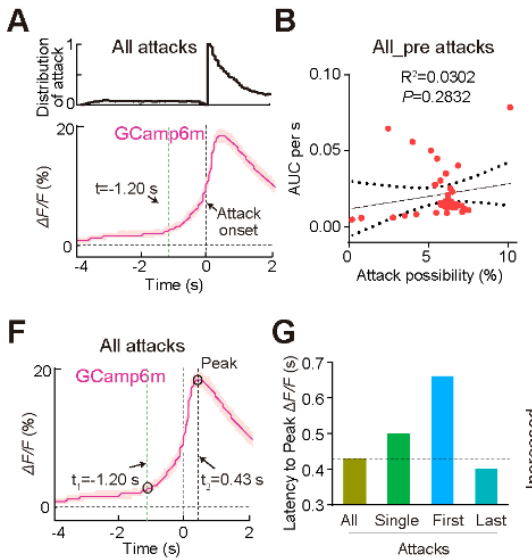

K single/last attack decoding $\mathbf{L}$

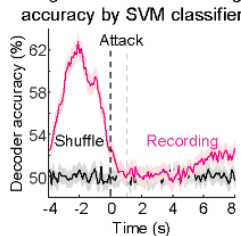

$\mathbf{P}$

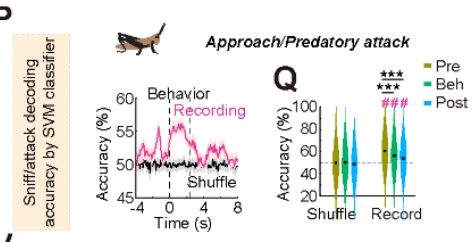

$\mathrm{V}$
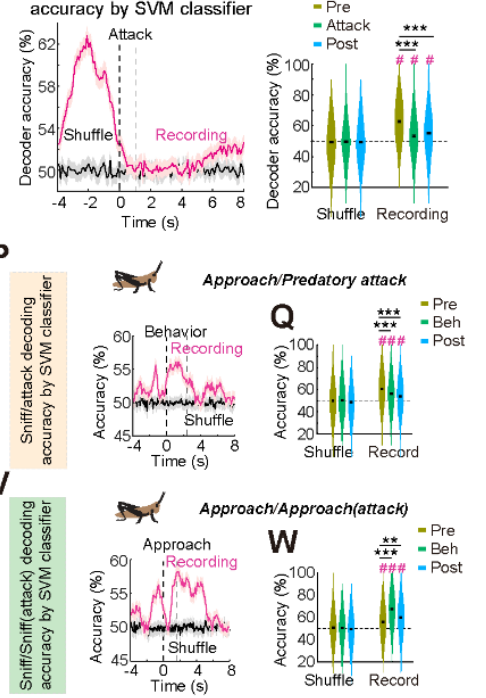

C

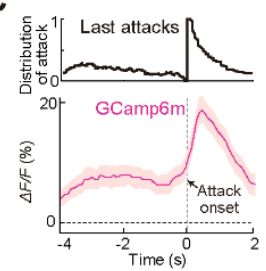

$\underset{\Delta F / F(\%)}{H}$ Increased $=\Delta F / F_{2}-\Delta F / F_{11}$

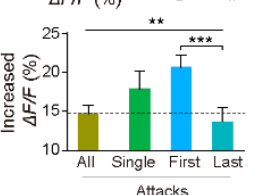

M

$\mathbf{R}$
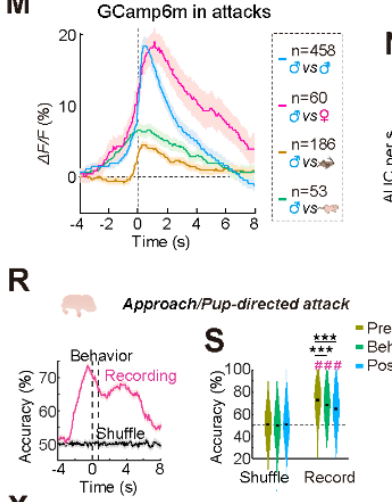

$\mathrm{X}$

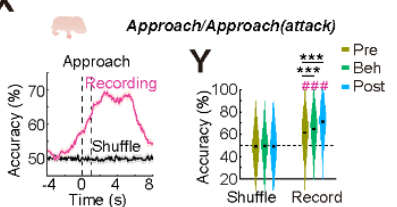

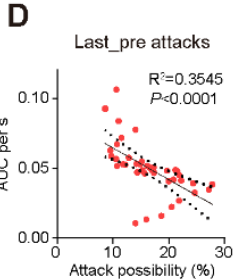

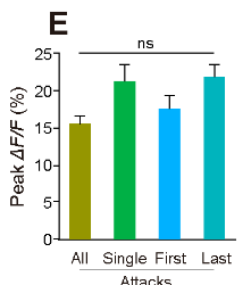
I Single/first attack decoding
accuracy by SVM classifier
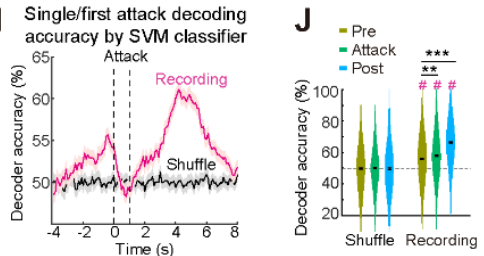

AB Four types of social behaviors decoding accuracy

$\mathrm{AC}$
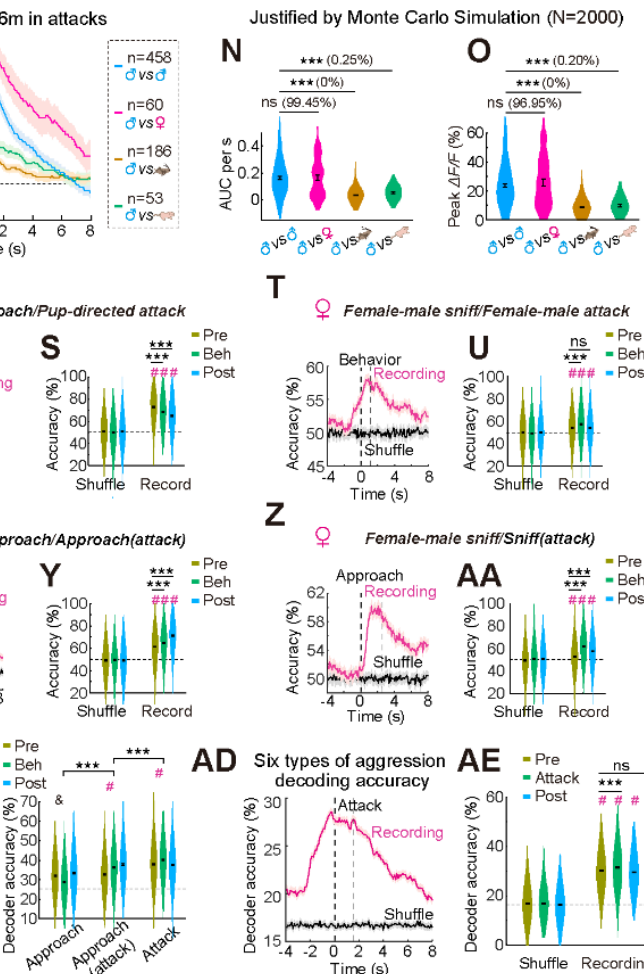

T

우 Female-male sniff/Female-male attack

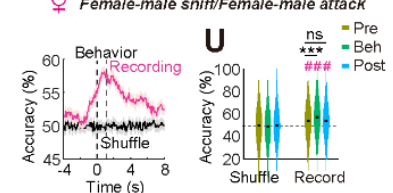

7

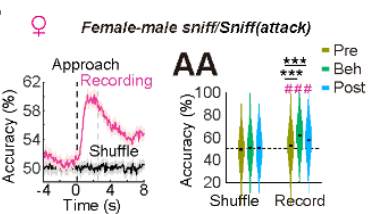

AD six types of aggression $A E$ - Pre
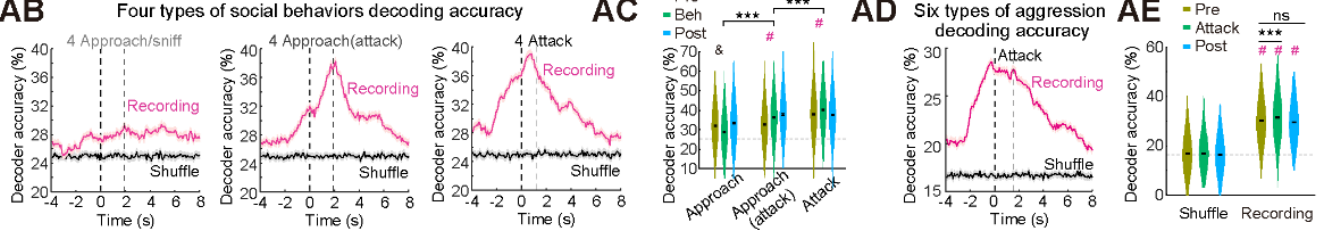
bioRxiv preprint doi: https://doi.org/10.1101/2020 04.22.047670; this version posted February 19, 2021. The copyright holder for this preprint (which was not certified by peer review) is the author/funder, who has granted bioRxiv a license to display the preprint in perpetuity. It is made available under aCC-BY-NC-ND 4.0 International license.

\section{Figure S4}

A Causal relationship between
aggression and various stimuli? - $\sqrt{\longrightarrow} \rightarrow$

Non-threat stimuli 0 Water, Food, Cotton, DMSO, Urine Non-social threat Social threat TMT Female entry Air puff Male entry Flying glove CD1 entry Object entry $\quad \begin{gathered}\text { Male entry } \\ (\text { attack) }\end{gathered}$

E
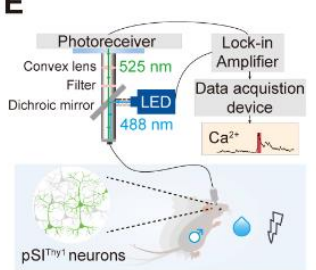

Responses to

Non-threat stimuli Water, Food, Cotton, DMSO, Urine Non-social threat Social threat $C$

TMT

Tail suspension

Flying glove
Object entry

Female entry

Male entry

Male entry

Male entry
(attack)
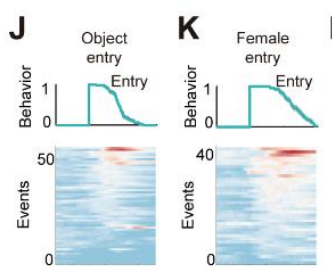

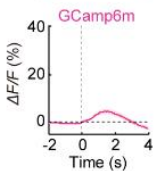
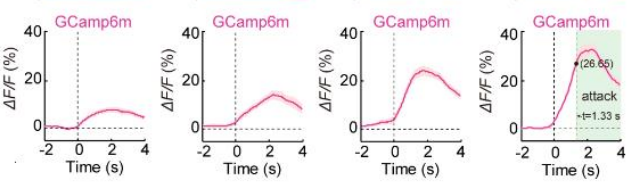

C

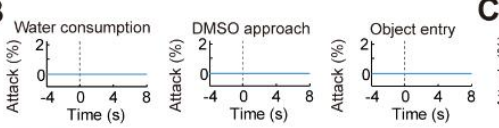

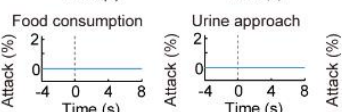
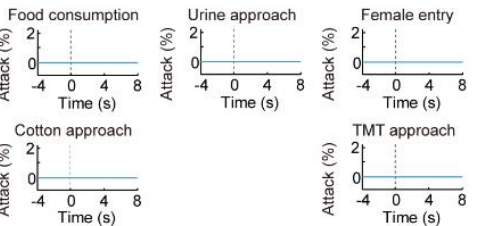

\section{F G}
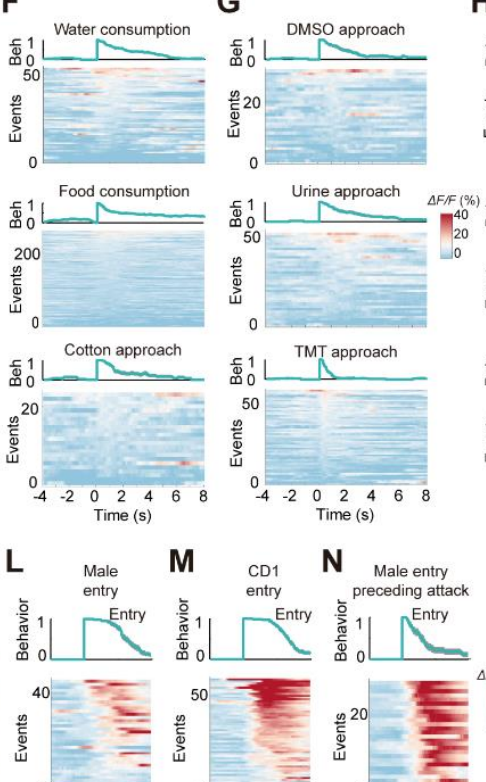
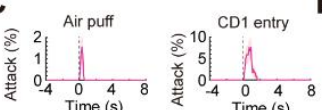

Possibilities in multiple behaviors showing attack Water Food Food $\mathrm{Con}=\mathrm{O}$ Cotto Urin

Flying glowe

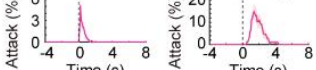
20 Male entry TMT Object entry

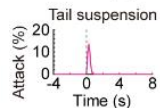
Female entry
Air puff Thying glove $\omega$ Tail suspension $1-$ CD1 entry
Male entry

H
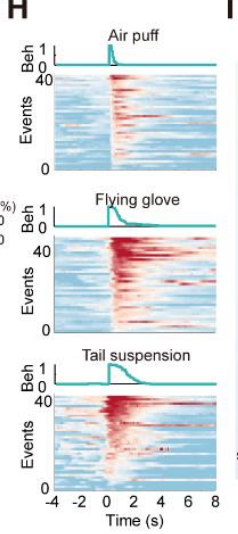

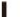

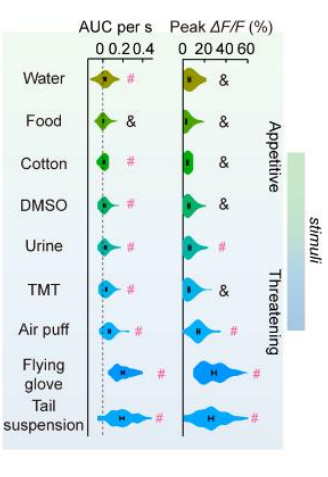

$\mathbf{L} \quad$ Male $\quad \mathbf{M} \quad \operatorname{CD} 1 \quad \mathbf{N}$ Male entry

$\Delta F / F(\%)$

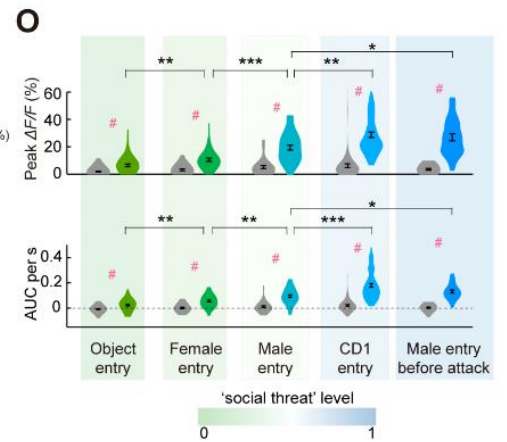


bioRxiv preprint doi: https://doi.org/10.1101/2020.04.22.047670; this version posted February 19, 2021. The copyright holder for this preprint (which was not certified by peer review) is the author/funder, who has granted bioRxiv a license to display the preprint in perpetuity. It is made available under aCC-BY-NC-ND 4.0 International license.

\section{Figure S5}
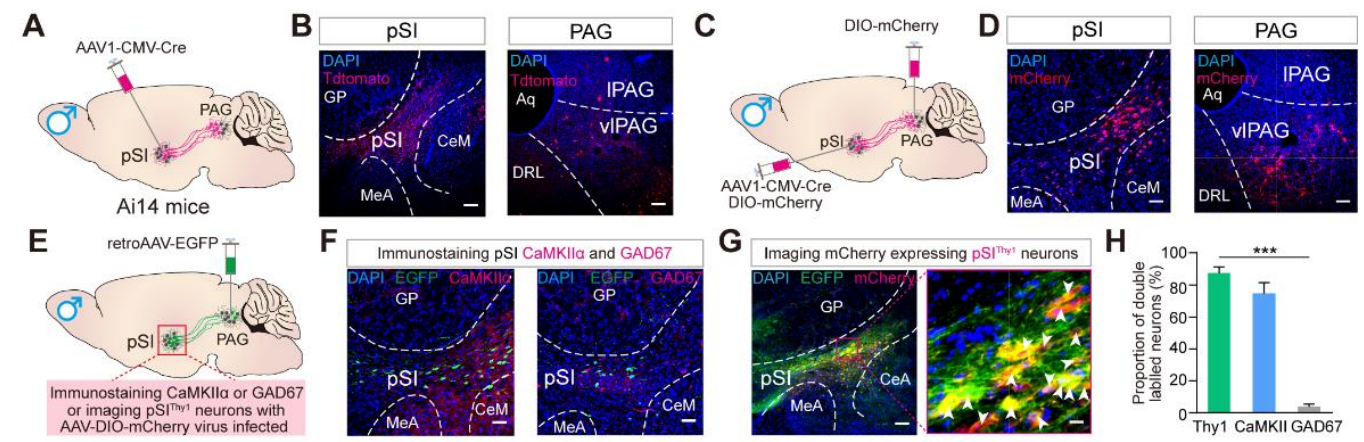

F Immunostaining pSI CaMKIla and GAD67

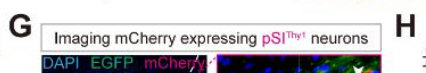
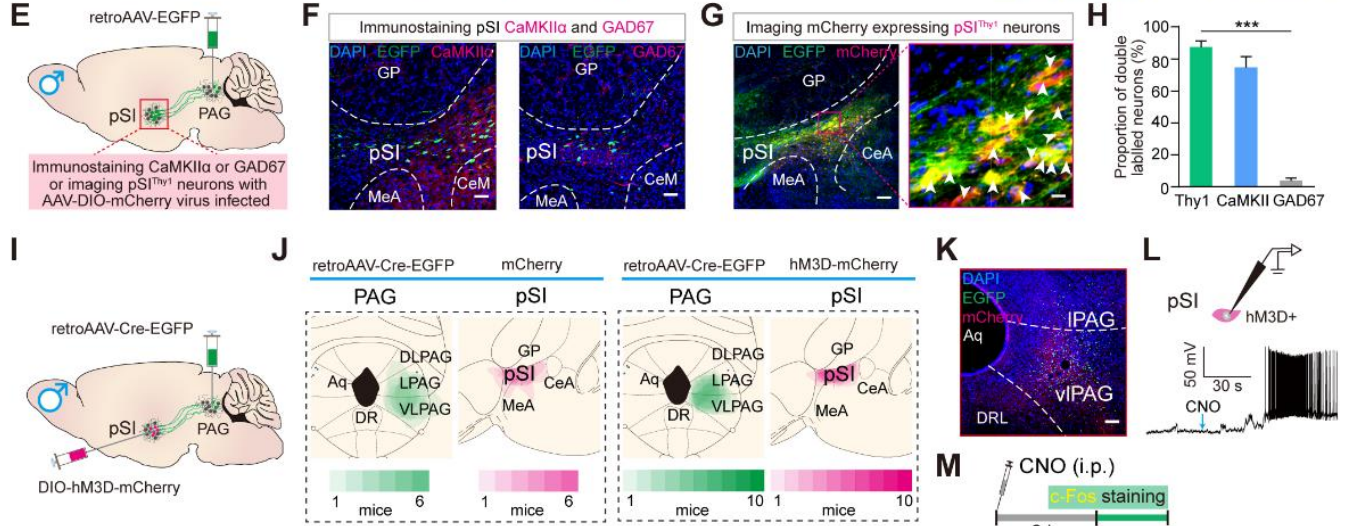

$\mathbf{N}$
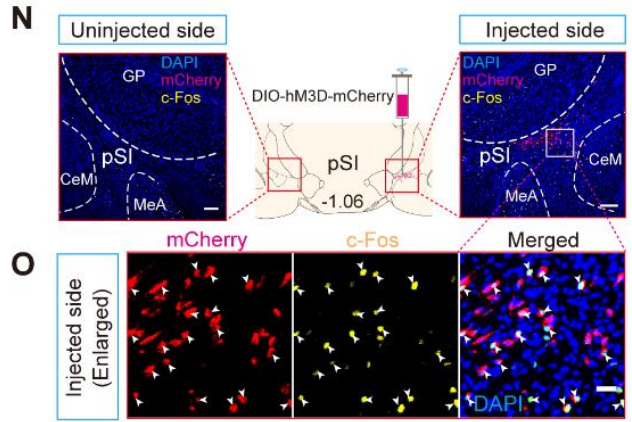

$\mathbf{P}$

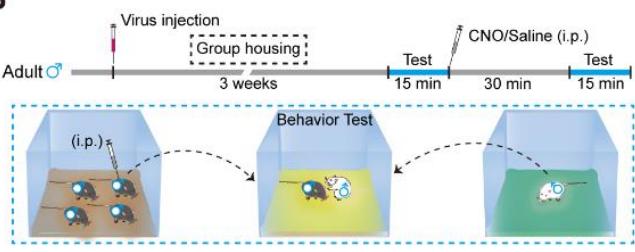

Q Sample raster plots of aggression (i.p.)
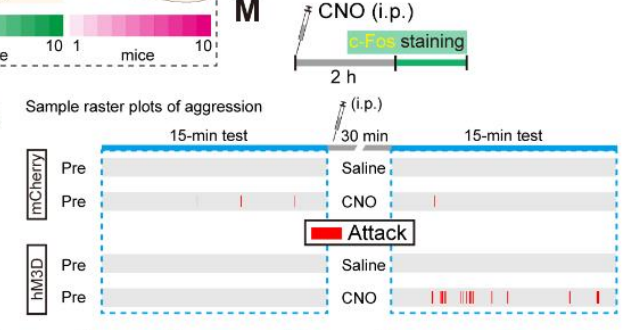

$\mathbf{R}$
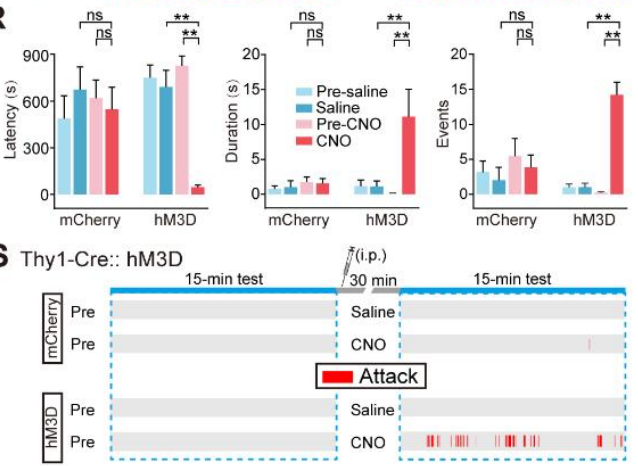
bioRxiv preprint doi: https://doi. org/10.1101/2020.04.22.047670; this version posted February 19,2021 . The copyright holder for this preprint (which was not certified by peer review) is the author/funder, who has granted bioRxiv a license to display the preprint in perpetuity. It is made available under aCC-BY-NC-ND 4.0 International license.

\section{Figure S6}

A

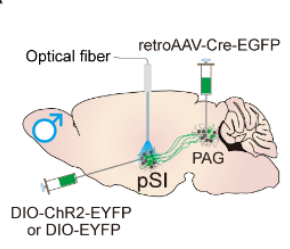

B

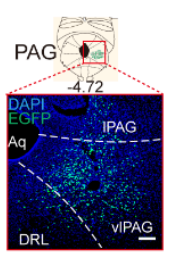

C

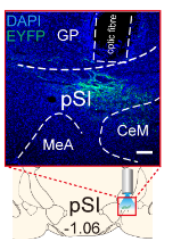

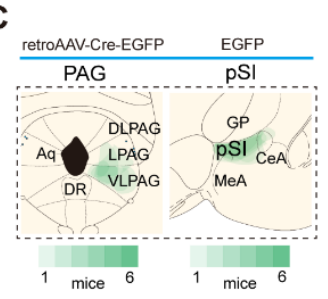

E
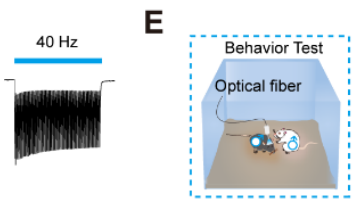

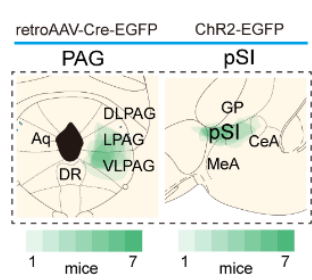

F

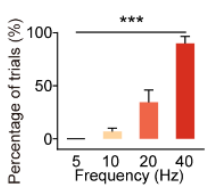

G
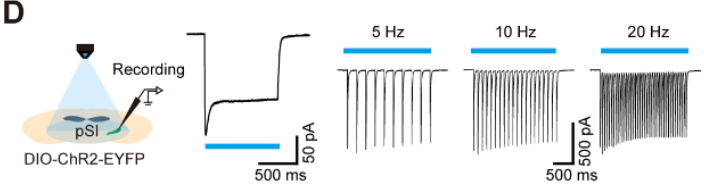

H

$473 \mathrm{~nm}=$ - Laser
Sham
H.
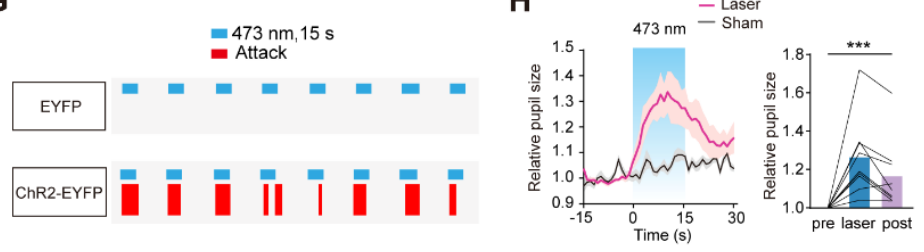

I

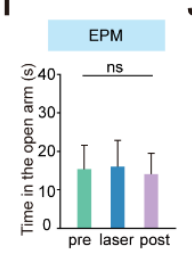

J

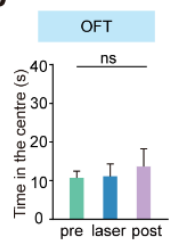

K

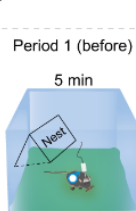

Behavior Test Period 2 (laser) Period 3 (after) $\frac{\text { pre, laser, post }}{15 \mathrm{~s}-15 \mathrm{~s}}$

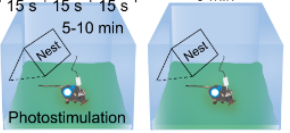

L

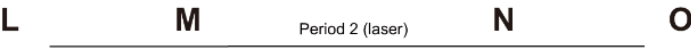

O Period 1-3

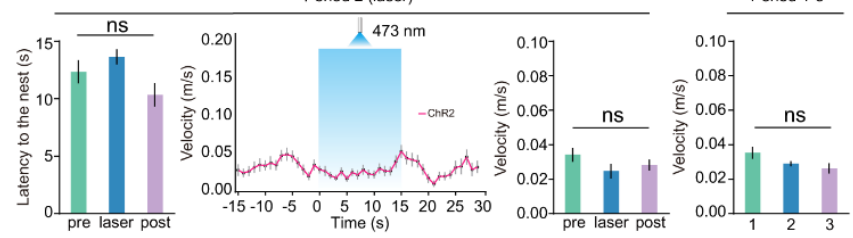

$\mathbf{P}$

$\mathbf{Q}_{\substack{\text { AAV-CaMkKlla-ChR2-mCherry } \\ \text { or AAV-CaMKKIla-mCherry }}}$
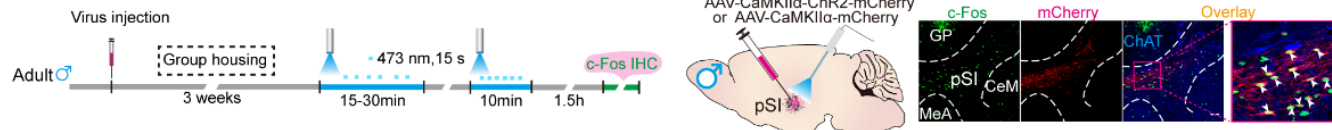

R

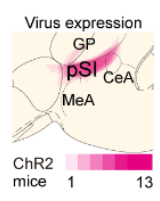

S

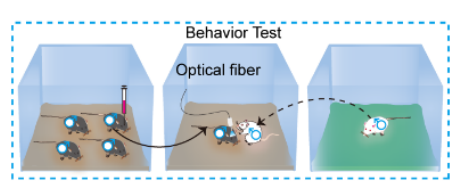

T

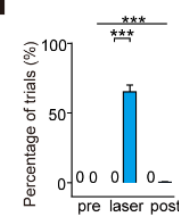

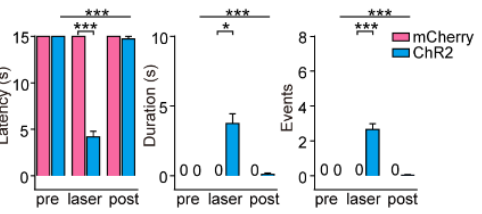


bioRxiv preprint doi: https://doi. org/10.1101/2020.04.22.047670; this version posted February 19, 2021. The copyright holder for this preprint (which was not certified by peer review) is the author/funder, who has granted bioRxiv a license to display the preprint in perpetuity. It is made available under aCC-BY-NC-ND 4.0 International license.

\section{Figure S7}

A

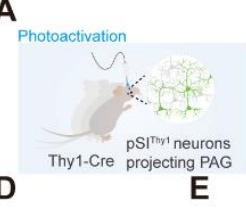

B

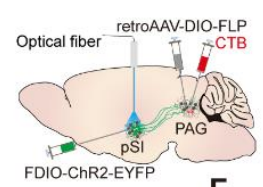

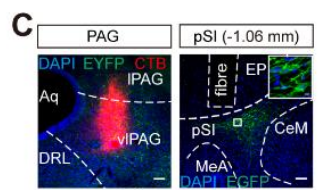

$\mathbf{G}_{\mathrm{n}=5}$

n=57 recorded PAG neurons

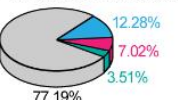
Excitation \& Inhibition

VLLLPAG

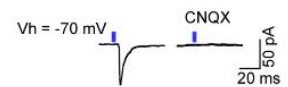
Inter-male aggression: vs

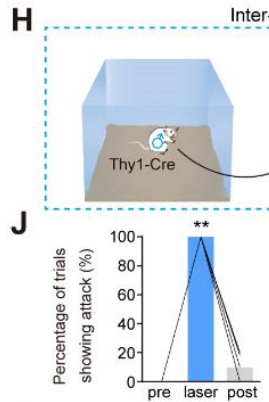

Optical fiber
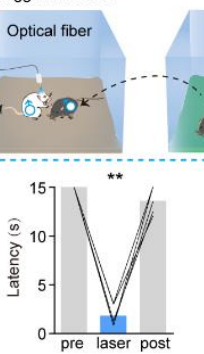

Predatory aggression

K

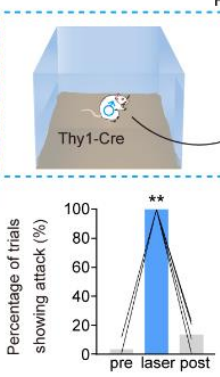

Optical fiber
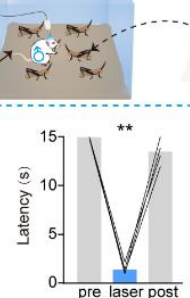
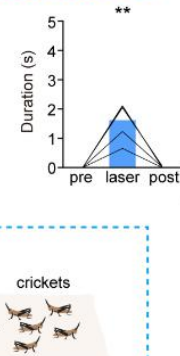

L

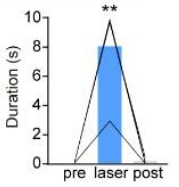

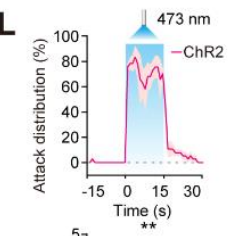

I
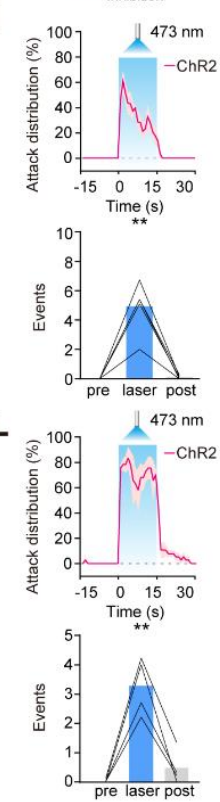
bioRxiv preprint doi: https://doi.org/10.1101/2020.04.22.047670; this version posted February 19, 2021. The copyright holder for this preprint (which was not certified by peer review) is the author/funder, who has granted bioRxiv a license to display the preprint in perpetuity. It is made available under aCC-BY-NC-ND 4.0 International license.

\section{Figure S8}

A

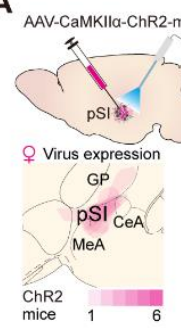

C
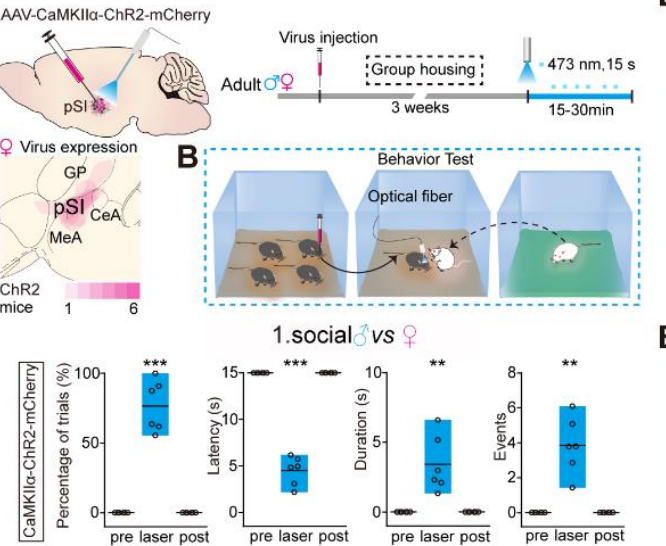

D

E
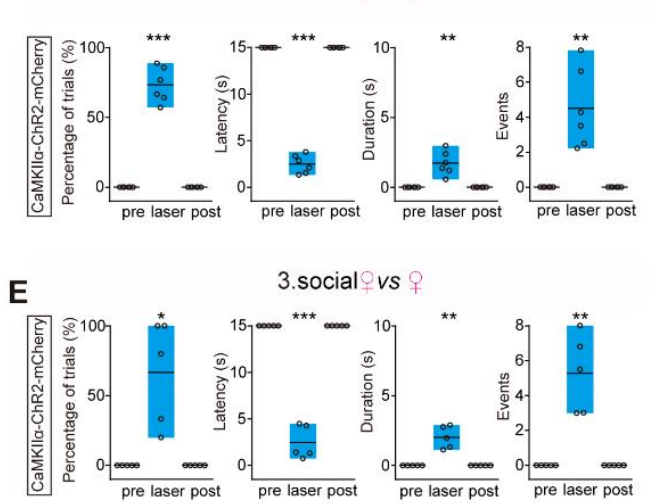

$\mathbf{F}$

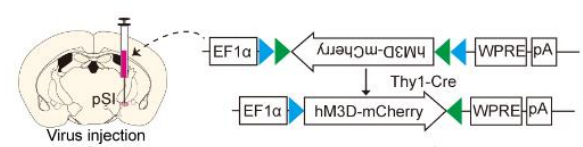

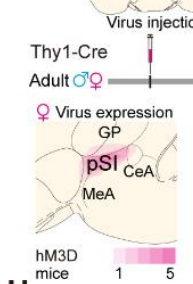

$\mathbf{H}^{\text {hice }}$

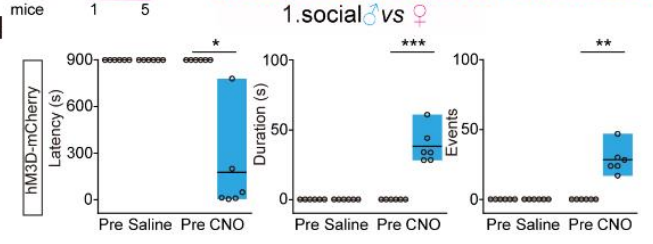

I
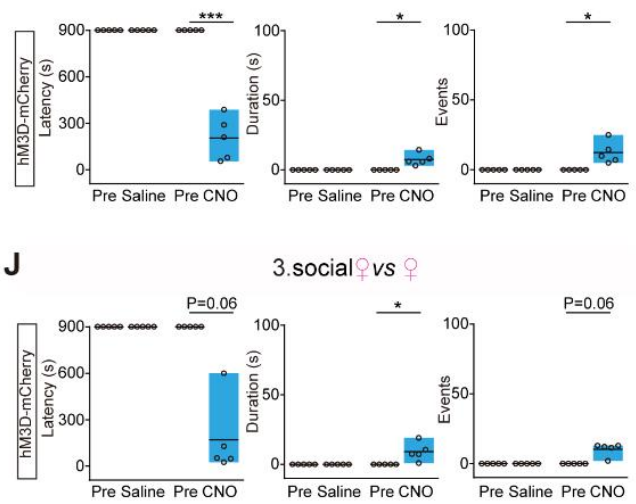
bioRxiv preprint doi: https://doi.org/10.1101/2020.04.22.047670; this version posted February 19, 2021. The copyright holder for this preprint (which was not certified by peer review) is the author/funder, who has granted bioRxiv a license to display the preprint in perpetuity. It is made available under aCC-BY-NC-ND 4.0 International license.

\section{Figure S9}

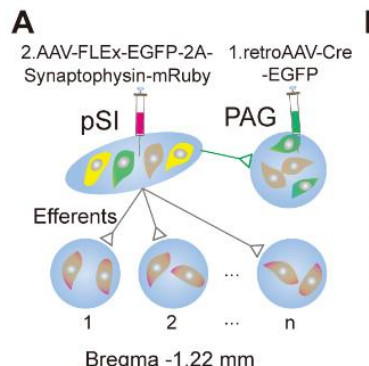

B Bregma $-0.58 \mathrm{~mm}$
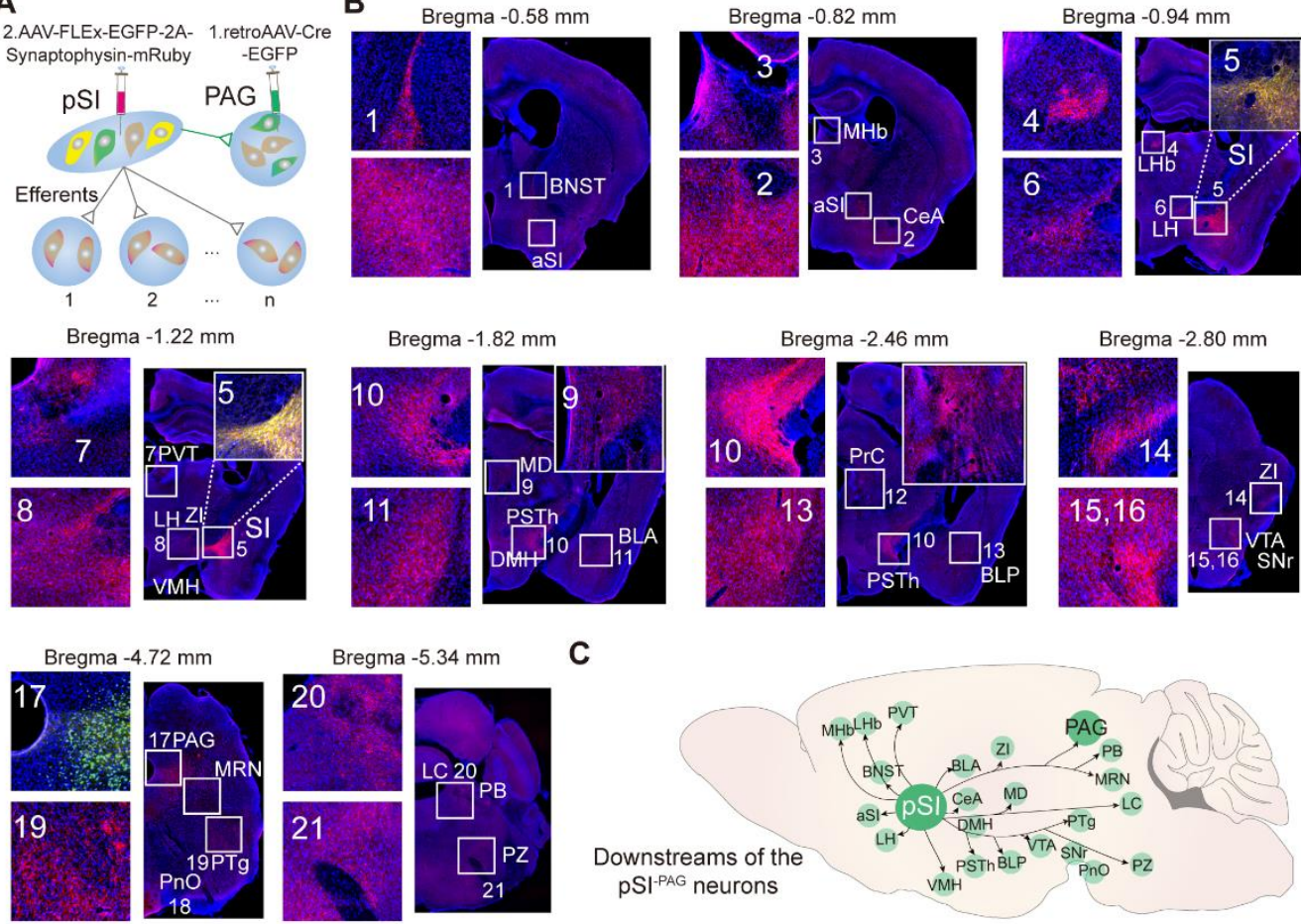
bioRxiv preprint doi: https://doi.org/10.1101/2020.04.22.047670; this version posted February 19, 2021. The copyright holder for this preprint (which was not certified by peer review) is the author/funder, who has granted bioRxiv a license to display the preprint in perpetuity. It is made available under aCC-BY-NC-ND 4.0 International license.

Figure S10

A
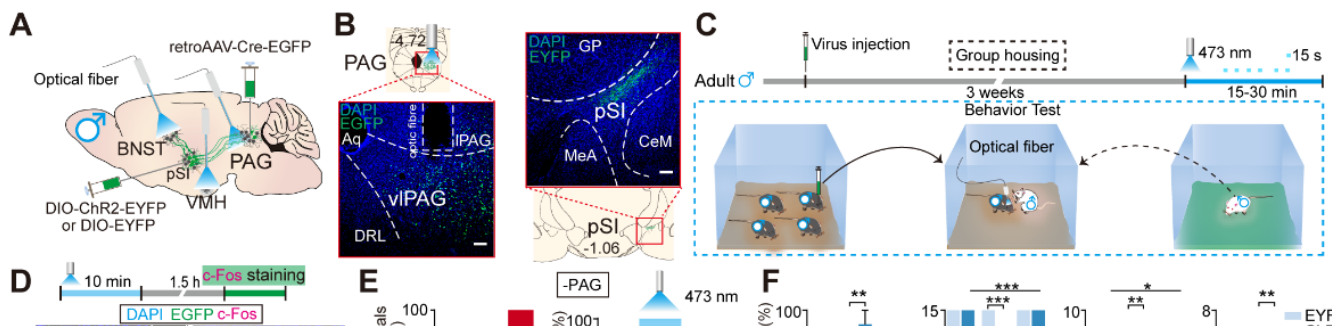

E
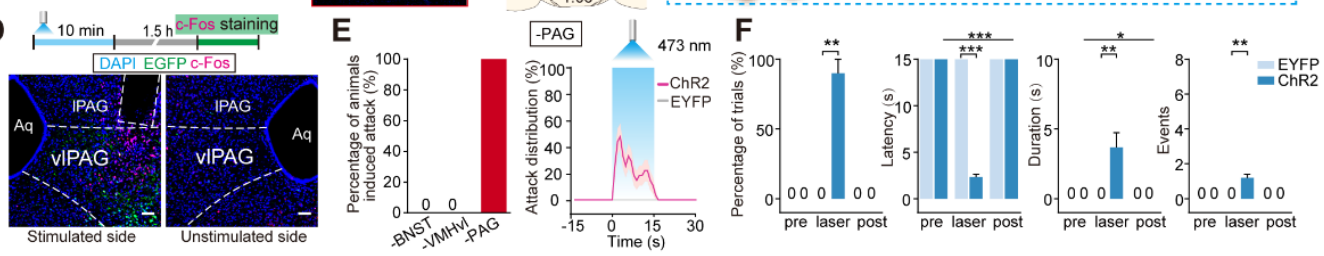

G Behavior Test

H
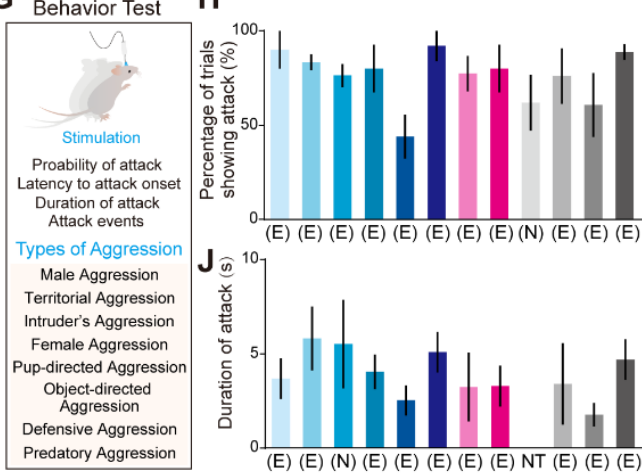

$\mathbf{L}$

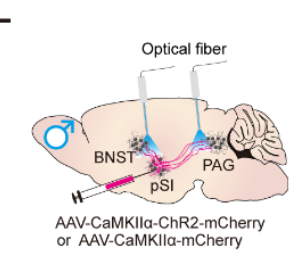

M

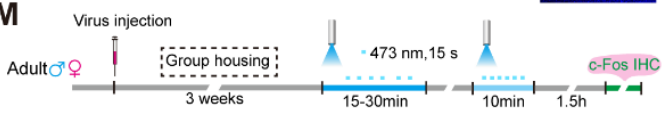

$\mathbf{N}$
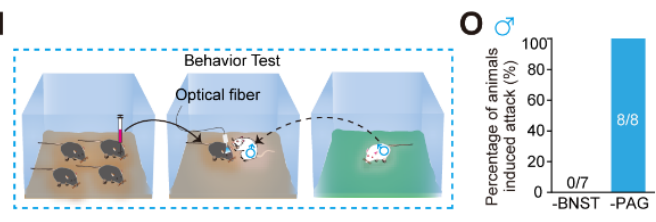

I

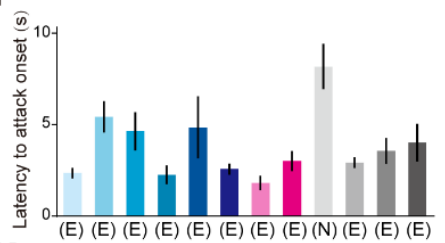

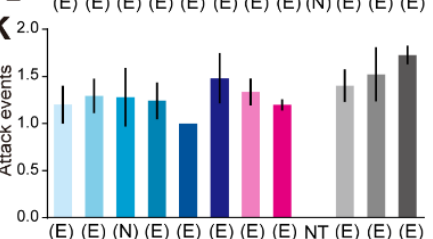

(E) (E) NT (E) (E) (E)

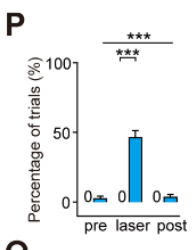

1.social vs
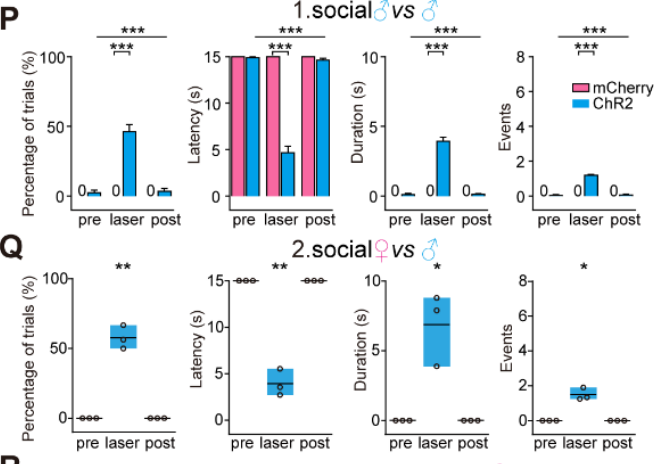

social vs

social vs (novel)

- single vs

single vs (novel)

social vs

- social vs

single vs pups

single vs gloves

- social vs (CD-1)

vs crickets

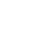

$\mathbf{R}_{\infty} \mathrm{O}^{7}$ Virus expression

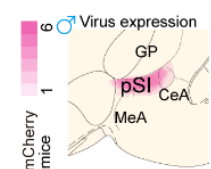

m ${ }_{m}$ 은 Virus expression

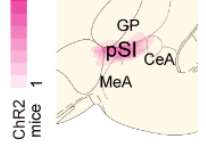


bioRxiv preprint doi: https://doi.org/10.1101/2020.04.22.047670; this version posted February 19, 2021. The copyright holder for this preprint (which was not certified by peer review) is the author/funder, who has granted bioRxiv a license to display the preprint in perpetuity. It is made available under aCC-BY-NC-ND 4.0 International license.

\section{Figure S11}
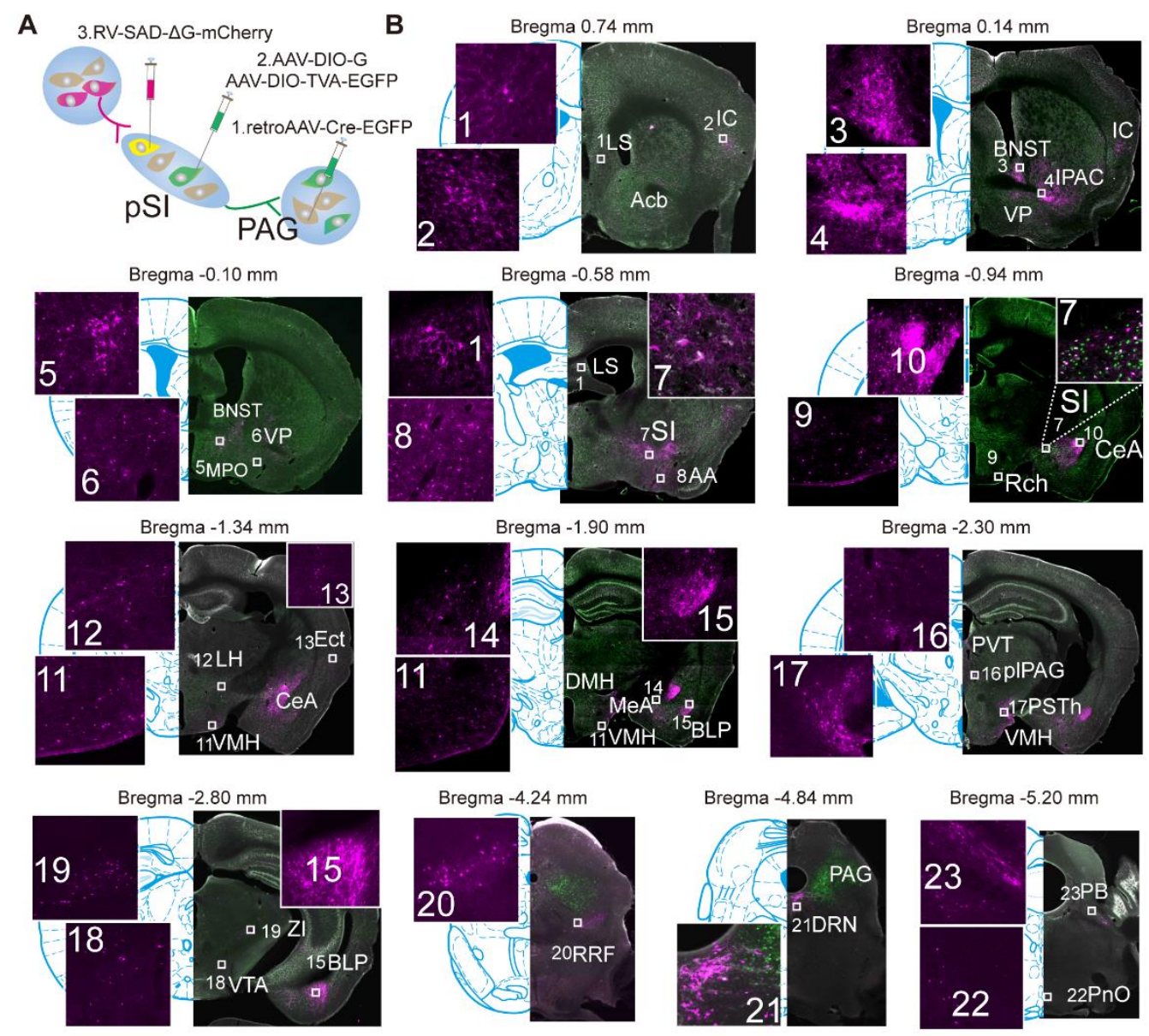

Bregma $-5.20 \mathrm{~mm}$

C

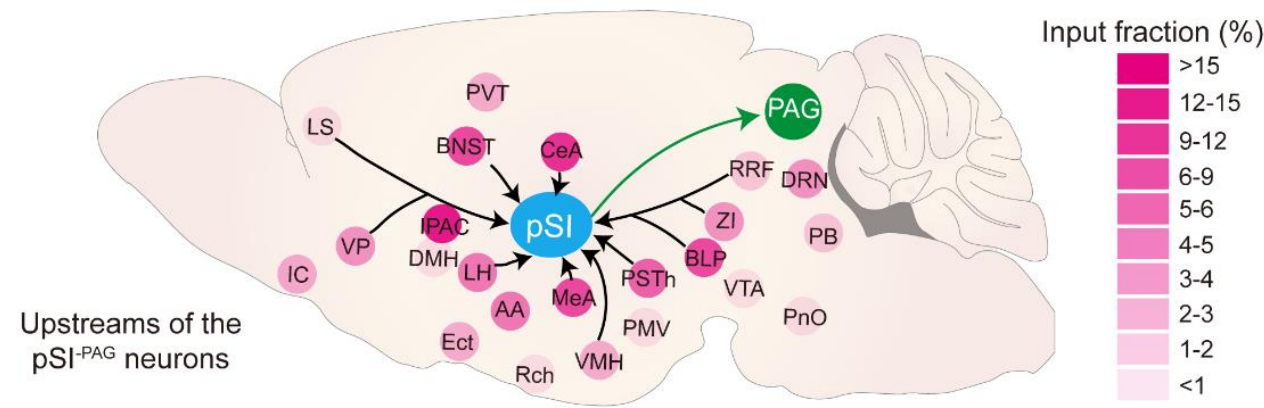


bioRxiv preprint doi: https://doi. org/10.1101/2020.04.22.047670; this version posted February 19,2021 . The copyright holder for this preprint (which was not certified by peer review) is the author/funder, who has granted bioRxiv a license to display the preprint in perpetuity. It is made available under aCC-BY-NC-ND 4.0 International license.

\section{Figure S12}

A

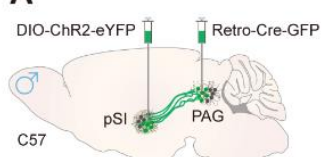

B

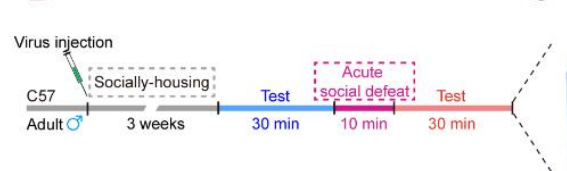

E

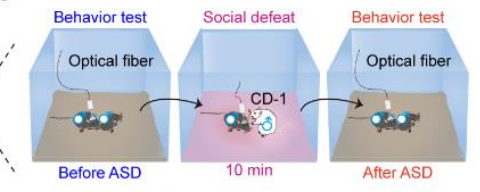

G
D

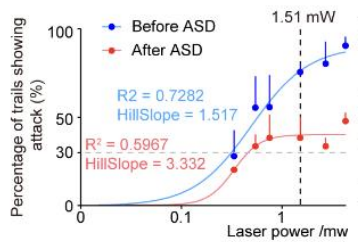

H

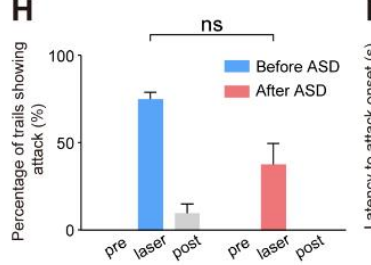

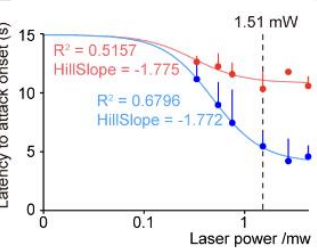

F
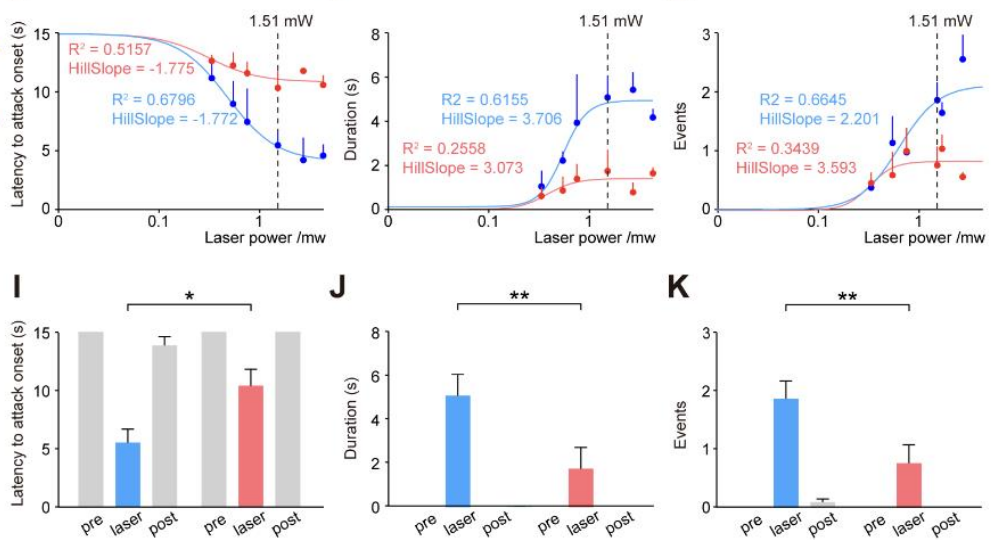

J

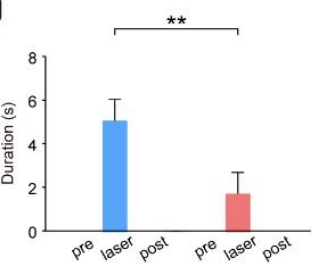

K

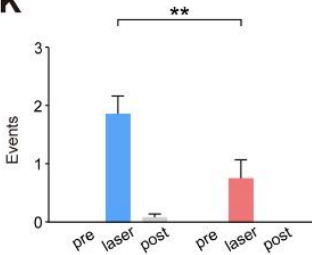


bioRxiv preprint doi: https://doi. org/10.1101/2020.04.22.047670; this version posted February 19, 2021. The copyright holder for this preprint (which was not certified by peer review) is the author/funder, who has granted bioRxiv a license to display the preprint in perpetuity. It is made available under aCC-BY-NC-ND 4.0 International license.

\section{Figure S13}

A

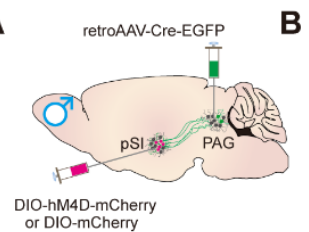

D Sample raster plots of aggression

15-min test

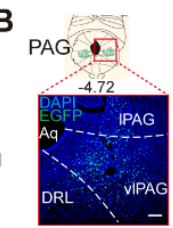

$7_{30 \text { min }}^{\text {(i.p.) }}$

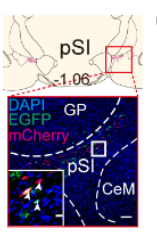

C

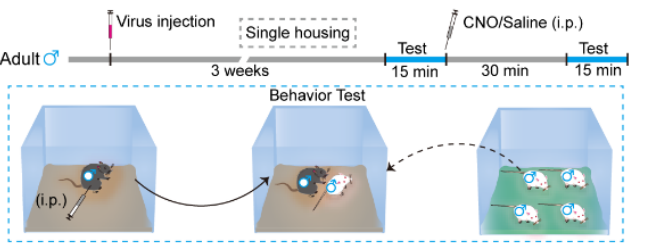

Pro

Pre

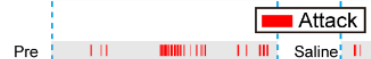

If Pre $:$ III III || || । ।

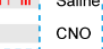

$\mathbf{F}$

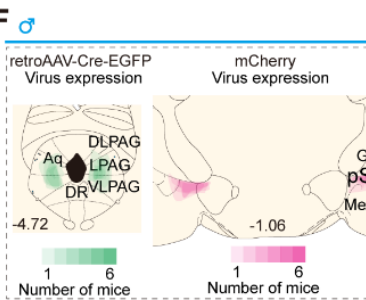

K Thy1-Cre mCherry

hM4D-mCherry
Virus expression

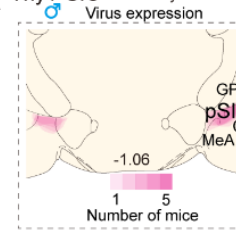

G o

retroAAV-Cre-EGFP

Virus expression
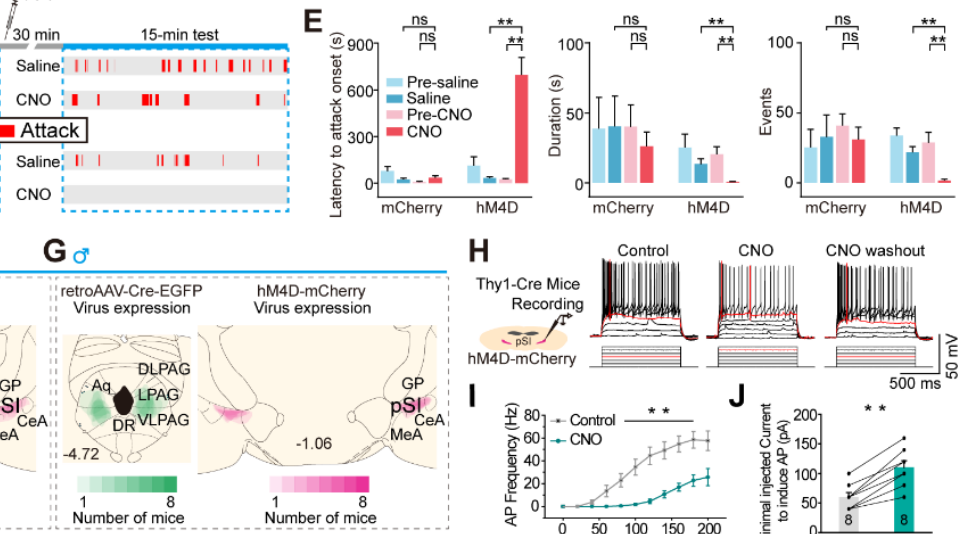

$\mathbf{H}$

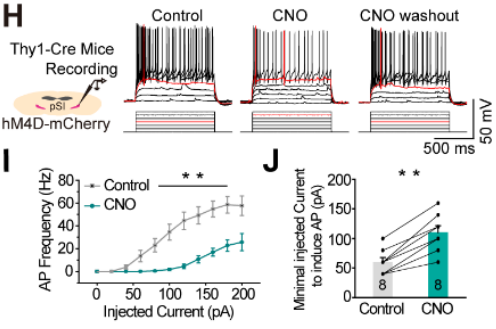

L

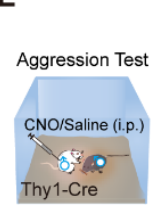

(i.p.)

$$
\text { 15-min test } \quad 30 \mathrm{~min} \text { 15-min test }
$$

图Pre || || | | || || | | Saline | || || | || | | |

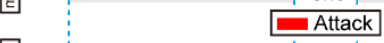

QPre

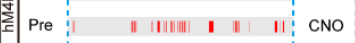


bioRxiv preprint doi: https://doi.org/10.1101/2020.04.22.047670; this version posted February 19, 2021. The copyright holder for this preprint (which was not certified by peer review) is the author/funder, who has granted bioRxiv a license to display the preprint in perpetuity. It is made available under aCC-BY-NC-ND 4.0 International license.

\section{Figure S14}

A

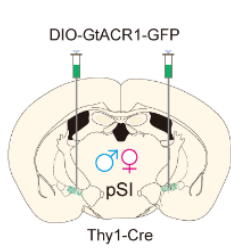

B

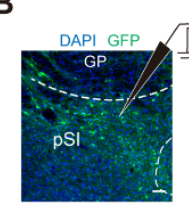

I

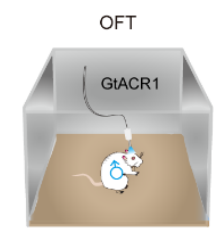

L

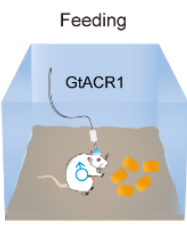

M
C

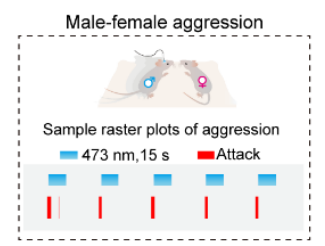

D

Female-male aggression Lactating female
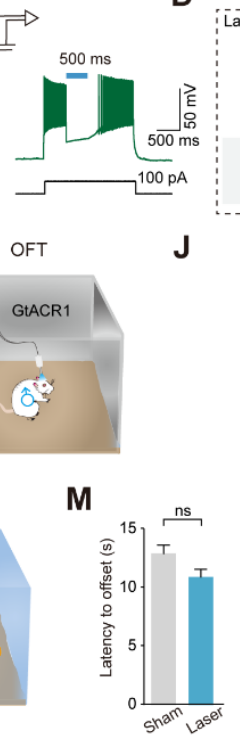

E

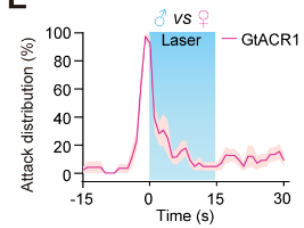

G
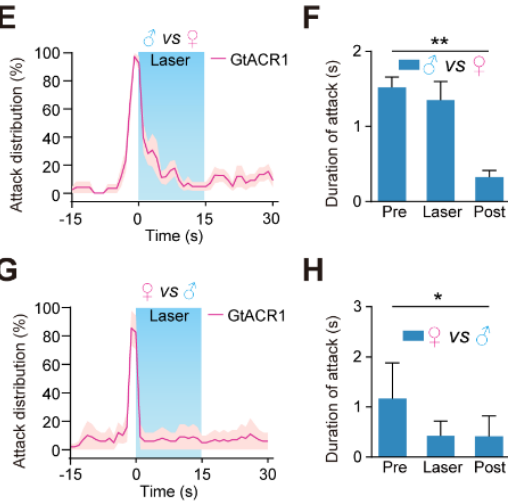

H

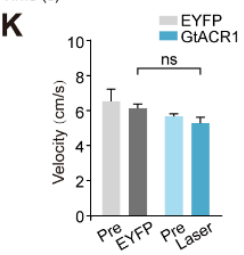

0

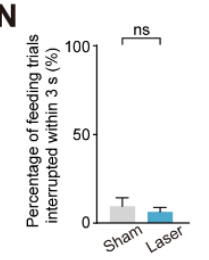

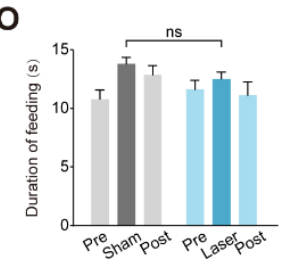

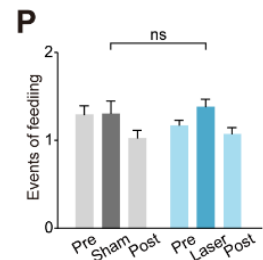

Table S1. Statistical data for all Figures

\begin{tabular}{|c|c|c|c|c|c|}
\hline Fig & Comparison & Analysis & Statistic value & P-value, F/T/W/U value & $\mathbf{N}$ \\
\hline 1B & $\begin{array}{l}\text { c-Fos+ neurons per slice in the } \\
\text { Control (sniff) vs Attack group }\end{array}$ & $\begin{array}{l}\text { Unpaired t-test; } \\
\text { Mann-Whitney test }\end{array}$ & $\begin{array}{l}\text { pSI: } 2.952 \pm 0.4402 \text { vs } 10.12 \pm 2.847 \text {; aSI: } \\
0.9056 \pm 0.7605 \text { vs } 1.623 \pm 0.8423 \text {;CeA: } \\
0.7083 \pm 0.1816 \text { vs } 1.250 \pm 0.3819 \text {;GP: } \\
0.1467 \pm 0.0769 \text { vs } 0.1675 \pm 0.0698 \text {; }\end{array}$ & $\begin{array}{l}\text { pSI: } P=0.0285 ; \mathrm{t}=2.488, \mathrm{df}=12 ; \mathrm{aSI}: P= \\
0.5000 ; \mathrm{U}=2.500 ; \quad \text { CeA: } P=0.5000 \text {; } \\
\mathrm{U}=2.000 ; \mathrm{GP}: P=0.7429 ; \mathrm{U}=5.000\end{array}$ & $\begin{array}{c}7 / 7 / 3 / 3 / 3 \\
/ 3 / 3 / 4 \\
\text { mice }\end{array}$ \\
\hline $1 \mathbf{E}$ & $\begin{array}{l}\text { Thy1 vs CaMKII } \alpha \text { vs ChAT vs } \\
\text { GAD67 }\end{array}$ & Kruskal-Wallis test & $\begin{array}{lcc}80.76 \pm 3.979 & v s \quad 76.82 \pm 9.086 & v s \\
2.778 \pm 2.778 \text { vs } & 2.5 \pm 2.5 & \\
\end{array}$ & $P=0.0002 ; \mathrm{KW}=13.67$ & $\begin{array}{l}6 / 5 / 3 / 5 \\
\text { mice }\end{array}$ \\
\hline $1 \mathrm{E}$ & Thy1 vs CaMKII $\alpha$ & Unpaired t-test & $24.5 \pm 3.6$ vs $33.7 \pm 6.7$ & $P=0.2349 ; \mathrm{t}=1.273, \mathrm{df}=9$ & $6 / 5$ mice \\
\hline 1J & $\begin{array}{l}\text { Mean population activity per } \\
\text { second (area under z-score } \\
\text { curve); All neurons }\end{array}$ & $\begin{array}{ll}\text { Paired } & \text { t- } \\
\text { test;Wilcoxon } & \\
\text { matched-pairs } & \\
\text { signed-rank } & \text { test; } \\
\text { Friedman test } & \\
\end{array}$ & $\begin{array}{l}6 \text { columns }(-2 \text { s to } 4 \text { s): } 0.00085 \pm 0.0001 \\
\text { vs } 0.1127 \pm 0.07825 \text { vs } 0.3322 \pm 0.09643 \text { vs } \\
0.3049 \pm 0.08694 \text { vs } 0.1607 \pm 0.08520 \text { vs } \\
0.1920 \pm 0.08485\end{array}$ & $\begin{array}{l}{[-1 \mathrm{~s} \quad v s \quad-2 \mathrm{~s}]: \quad P=0.1566, \mathrm{t}=1.426} \\
\mathrm{df}=112 ;[1 \mathrm{~s} v s-2 \mathrm{~s}]: P<0.001, \mathrm{~W}=2391 ; 6 \\
\text { columns: } P=0.0458, \mathrm{FM}=11.30\end{array}$ & $\begin{array}{l}113 / 113 \\
\text { neurons }\end{array}$ \\
\hline $1 \mathrm{~L}$ & $\begin{array}{l}\text { Mean population activity per } \\
\text { second (area under z-score } \\
\text { curve); 'attack-active' neurons }\end{array}$ & $\begin{array}{l}\text { Paired } \\
\text { test;Wilcoxon } \\
\text { matched-pairs } \\
\text { signed-rank } \\
\text { Friedman test }\end{array}$ & $\begin{array}{l}6 \text { columns }(-2 \text { s to } 4 \text { s): }-0.00028 \pm 0.0013 \\
\text { vs } 0.5620 \pm 0.1416 \text { vs } 1.202 \pm 0.1457 \text { vs } \\
0.9873 \pm 0.1383 \text { vs } 0.6930 \pm 0.1345 \text { vs } \\
0.6567 \pm 0.1531\end{array}$ & $\begin{array}{l}{[-1 \mathrm{~s} v s-2 \mathrm{~s}]: P<0.001, \mathrm{t}=3.959, \mathrm{df}=43 ;[1 \mathrm{~s}} \\
v s-2 \mathrm{~s}]: P<0.001, \mathrm{~W}=990 ; 6 \text { columns: } P< \\
0.001, \mathrm{FM}=75.84\end{array}$ & $\begin{array}{c}44 / 44 \\
\text { neurons }\end{array}$ \\
\hline $1 \mathrm{M}$ & $\begin{array}{l}\text { Mean population activity per } \\
\text { second (area under z-score } \\
\text { curve); 'attack-active' neurons }\end{array}$ & $\begin{array}{l}\text { Repeated one-way } \\
\text { ANOVA }\end{array}$ & $\begin{array}{l}6 \text { columns }(-2 \text { s to } 4 \text { s): }-0.00029 \pm 0.0013 \\
\text { vs }-0.043 \pm 0.1009 \text { vs } 0.0055 \pm 0.1379 \text { vs } \\
0.04501 \pm 0.1349 \text { vs }-0.06792 \pm 0.1565 \text { vs }- \\
0.06651 \pm 0.1137\end{array}$ & $\begin{array}{l}6 \text { columns: } P=0.8913, \mathrm{~F}(3.732,134.3)= \\
0.2613\end{array}$ & $\begin{array}{c}37 \\
\text { neurons }\end{array}$ \\
\hline $1 \mathbf{N}$ & $\begin{array}{l}\text { Mean population activity per } \\
\text { second (area under z-score } \\
\text { curve); 'attack-active' neurons }\end{array}$ & Friedman test & $\begin{array}{l}6 \text { columns }(-2 \text { s to } 4 \text { s): }-0.001834 \pm 0.0012 \\
\text { vs }-0.09239 \pm 0.1349 \text { vs } 0.2831 \pm 0.2179 \text { vs } \\
0.3748 \pm 0.2179 \text { vs } 0.1418 \pm 0.1846 \text { vs }- \\
0.02886 \pm 0.1559\end{array}$ & 6 columns: $P=0.0273, \mathrm{FM}=12.61$ & $\begin{array}{c}37 \\
\text { neurons }\end{array}$ \\
\hline $\mathbf{1 P}$ & $\begin{array}{l}\text { Mean population activity per } \\
\text { second (area under z-score }\end{array}$ & Friedman test & $\begin{array}{l}6 \text { columns }(-2 \text { s to } 4 \text { s): }-0.00094 \pm 0.0016 \\
\text { vs }-0.1966 \pm 0.1336 \text { vs } 0.2948 \pm 0.1252 \text { vs }\end{array}$ & 6 columns: $P=0.2134, \mathrm{FM}=7.099$ & $\begin{array}{c}26 \\
\text { neurons }\end{array}$ \\
\hline
\end{tabular}


bioRxiv preprint doi: https://doi.org/10.1101/2020.04.22.047670; this version posted February 19, 2021. The copyright holder for this preprint (which was not certified by peer review) is the author/funder, who has granted bioRxiv a license to display the preprint in perpetuity. It is made available under aCC-BY-NC-ND 4.0 International license.

\begin{tabular}{|c|c|c|c|c|c|}
\hline & $\begin{array}{l}\text { curve); 'Object sniff-active' } \\
\text { neurons. }\end{array}$ & & $\begin{array}{lll}0.3180 \pm 0.1368 & \text { vs } & 0.2804 \pm 0.1555 \\
0.09248 \pm 0.1323 & \end{array}$ & & \\
\hline 1R & $\begin{array}{l}\text { Mean population activity per } \\
\text { second (area under z-score } \\
\text { curve); 'Male sniff-active' } \\
\text { neurons. }\end{array}$ & Friedman test & $\begin{array}{l}6 \text { columns }(-2 \text { s to } \quad 4 \\
0.002916 \pm 0.001471 \text { vs } 0.2613 \pm 0.1824 \\
0.4357 \pm 0.2319 \text { vs } 0.4139 \pm 0.1918 \\
0.1320 \pm 0.1646 \text { vs } 0.1367 \pm 0.1933\end{array}$ & 6 columns: $P=0.2090, \mathrm{FM}=7.161$ & $\begin{array}{c}32 \\
\text { neurons }\end{array}$ \\
\hline $2 \mathrm{E}$ & $\begin{array}{l}\text { EYFP and GCamp6m Group } \\
\text { in sniff and sniff (attack) }\end{array}$ & Mann-Whitney test & $\begin{array}{lcc}2.276 \pm 0.6475 & \text { vs } \quad 9.902 \pm 0.8186 \\
1.848 \pm 0.5129 & \text { vs } 21.23 \pm 1.811\end{array}$ & $\begin{array}{l}\text { GCamp6m vs EYFP in sniff, } P<0.001 \text {, } \\
\text { U=5415;GCamp6m vs EYFP in sniff } \\
\text { (attack), } P<0.001, \mathrm{U}=949.0\end{array}$ & $\begin{array}{c}55 / 343 / 2 \\
9 / 236 \\
\text { trials }\end{array}$ \\
\hline $2 F$ & $\begin{array}{l}\text { GCamp6m Group in sniff and } \\
\text { sniff (attack), Peak value of } \\
\text { pre-sniff, sniff and post-sniff }\end{array}$ & Mann-Whitney test & $\begin{array}{lcc}8.923 \pm 0.6919 & \text { vs } & 9.902 \pm 0.8186 \\
8.210 \pm 0.8686 & \text { vs } & 14.42 \pm 1.504 \\
21.23 \pm 1.811 \text { vs } & 28.09 \pm 1.965 \\
\end{array}$ & $\begin{array}{l}\text { sniff } v s \text { sniff (attack): pre-sniff, } P<0.001 \text {, } \\
\mathrm{U}=32851 \text {; sniff, } P<0.001 \text {, U=25656; post- } \\
\text { sniff, } P<0.001, \mathrm{U}=17216\end{array}$ & $\begin{array}{c}343 / 236 \mathrm{t} \\
\text { rials }\end{array}$ \\
\hline $2 \mathrm{H}$ & $\begin{array}{l}\text { Sniff/sniff (attack) decoding } \\
\text { accuracy in shuffle and } \\
\text { recoding }\end{array}$ & $\begin{array}{l}\text { Mann-Whitney test; } \\
\text { Wilcoxon matched- } \\
\text { pairs signed-rank } \\
\text { test }\end{array}$ & $\begin{array}{llr}50.25 \pm 0.4583 & \text { vs } & 50.06 \pm 0.4483 \\
50.85 \pm 0.4598 & \text { vs } & 54.45 \pm 0.4369 \\
69.02 \pm 0.4278 \text { vs } & 64.80 \pm 0.4514\end{array}$ & $\begin{array}{l}\text { Shuffle } v s \text { recoding: Pre, } P<0.001 \text {, } \\
\mathrm{U}=417829 ; \text { sniff, } P<0.001, \mathrm{U}=170821 \text {; } \\
\text { Post, } P<0.001, \mathrm{U}=250602 . \text { Recoding: Pre } \\
v s \text { sniff, } P<0.001, \mathrm{~W}=273731 ; \text { Pre } v s \text { post, } \\
P<0.001, \mathrm{~W}=198811\end{array}$ & $\begin{array}{c}1000 / 100 \\
0\end{array}$ \\
\hline $2 \mathrm{~L}$ & $\begin{array}{l}\text { GCamp6m Group in sniff, } \\
\text { sniff (attack), and threat, Peak } \\
\text { value of pre-behavior, } \\
\text { behavior and post-behavior }\end{array}$ & $\begin{array}{l}\text { Wilcoxon matched- } \\
\text { pairs signed-rank } \\
\text { test; Paired t-test; } \\
\text { Mann-Whitney test }\end{array}$ & $\begin{array}{lll}9.113 \pm 2.548 & v s & 7.032 \pm 3.543 \\
8.816 \pm 3.204 & v s & 7.723 \pm 2.115 \\
17.37 \pm 3.290 & v s & 17.88 \pm 3.513 \\
12.70 \pm 1.997 & v s & 17.06 \pm 2.609 \\
20.60 \pm 2.753 & & \end{array}$ & $\begin{array}{l}\mathrm{Pre}_{-}^{\text {rattle }} v s \text { rattle, } P=0.1814, \mathrm{~W}=-107 \\
\mathrm{Pre} \text { rattle } v s \text { rattle (attack), } P=0.0094, \\
\mathrm{~W}=201 ; \text { Pre_threat } v s \text { threat, } P=0.002 \text {, } \\
\mathrm{t}=3.261 \mathrm{df}=48 \text {;rattle } v s \text { rattle (attack), } P= \\
0.0129, \mathrm{U}=203 \text {;rattle (attack) vs threat, } P= \\
0.9432, \mathrm{t}=0.07152 \mathrm{df}=73\end{array}$ & $\begin{array}{c}26 / 26 / 49 \\
\text { trials }\end{array}$ \\
\hline $2 \mathrm{~N}$ & $\begin{array}{l}\text { Rattle/rattle (attack) decoding } \\
\text { accuracy in shuffle and } \\
\text { recoding }\end{array}$ & $\begin{array}{l}\text { Mann-Whitney test; } \\
\text { Wilcoxon matched- } \\
\text { pairs signed-rank } \\
\text { test }\end{array}$ & $\begin{array}{lcr}50.19 \pm 0.4471 & \text { vs } & 50.35 \pm 0.4554 \\
50.30 \pm 0.4781 & \text { vs } & 58.00 \pm 0.4646 \\
66.08 \pm 0.4327 & \text { vs } & 63.31 \pm 0.4821\end{array}$ & $\begin{array}{l}\text { Shuffle } v s \text { recoding: Pre, } P<0.001 \text {, } \\
\mathrm{U}=352170 \text {; rattle, } P<0.001, \mathrm{U}=218929 \text {; } \\
\text { Post } P<0.001, \mathrm{U}=272458 . \text { Recoding: Pre } \\
v s \text { rattle, } P<0.001, \mathrm{~W}=156413 \text {; Pre } v s \text { post, } \\
P<0.001, \mathrm{~W}=103151\end{array}$ & $\begin{array}{c}1000 / 100 \\
0\end{array}$ \\
\hline 20 & $\begin{array}{l}\text { GCamp6m Group in } 6 \text { types of } \\
\text { social behaviors, Peak value } \\
\text { during social behaviors }\end{array}$ & $\begin{array}{l}\text { Mann-Whitney test; } \\
\text { Kruskal-Wallis test }\end{array}$ & \multirow{2}{*}{$\begin{array}{lcc}7.032 \pm 3.543 & \text { vs } & 9.902 \pm 0.8186 \\
17.37 \pm 3.290 & \text { vs } & 21.23 \pm 1.811 \\
17.06 \pm 2.609 & \text { vs } & 23.43 \pm 1.143\end{array}$} & $\begin{array}{l}\text { rattle } v s \text { sniff, } P=0.0775, \mathrm{U}=3534 \text {;rattle } \\
\text { (attack) vs sniff (attack) vs threat, } P= \\
0.5532, \mathrm{KW}=1.184 \text {; sniff } v \text { s sniff (attack), } P \\
<0.001, \mathrm{U}=25656 \text {; attack vs sniff (attack), } \\
P=0.0193, \mathrm{U}=48187\end{array}$ & \multirow{4}{*}{$\begin{array}{l}26 / 343 / 2 \\
6 / 236 / 49 \\
1458 \\
\text { trials }\end{array}$} \\
\hline 20 & $\begin{array}{l}\text { GCamp6m Group in } 6 \text { types of } \\
\text { social behaviors, Peak value } \\
\text { during social behaviors }\end{array}$ & $\begin{array}{l}\text { Mann-Whitney test; } \\
\text { Kruskal-Wallis test }\end{array}$ & & $\begin{array}{l}\text { rattle, } P=0.1814, \mathrm{~W}=-107 ; \text { sniff, } P= \\
0.0404, \mathrm{~W}=7536 \text {;rattle (attack), } P=0.0094, \\
\mathrm{~W}=201 \text {; sniff (attack), } P \quad 0.001 \text {, } \\
\mathrm{W}=11552 \text {; threat, } P<0.001, \mathrm{t}=3.261 \mathrm{df}=48 ; \\
\text { attack, } P<0.001, \mathrm{~W}=63625\end{array}$ & \\
\hline 20 & $\begin{array}{l}\text { GCamp6m Group in } 6 \text { types of } \\
\text { social behaviors, Area under } \\
\text { curve per s }\end{array}$ & $\begin{array}{l}\text { Mann-Whitney test; } \\
\text { Kruskal-Wallis test }\end{array}$ & \multirow{2}{*}{$\begin{array}{l}0.02494 \pm 0.03053 \text { vs } 0.03004 \pm 0.00646 \\
0.08252 \pm 0.02238 \text { vs } 0.1237 \pm 0.0159 \\
0.1342 \pm 0.02293 \text { vs } 0.1632 \pm 0.01011\end{array}$} & $\begin{array}{l}\text { rattle vs sniff, } P=0.3028, \mathrm{U}=3917 \text {; rattle } \\
\text { (attack) vs sniff (attack) vs threat, } P= \\
0.4294, \mathrm{KW}=1.691 \text {; sniff } v s \text { sniff (attack), } P \\
<0.001, \mathrm{U}=24892 \text {; attack } v s \text { sniff (attack), } \\
P<0 \text {.001, U=43684 }\end{array}$ & \\
\hline 20 & $\begin{array}{l}\text { GCamp6m Group in each } 6 \\
\text { types of social behaviors, Area } \\
\text { under curve per } s \text { of pre- } \\
\text { behavior and during behavior }\end{array}$ & $\begin{array}{l}\text { Mann-Whitney test; } \\
\text { Paired t-test; } \\
\text { Wilcoxon matched- } \\
\text { pairs signed-rank } \\
\text { test }\end{array}$ & & $\begin{array}{l}\text { rattle, } P=0.5317, \mathrm{U}=-51 ; \text { sniff, } P= \\
0.0610, \mathrm{~W}=6888 \text {;rattle (attack), } P=0.0032, \\
\mathrm{~W}=225 ; \text {;niff } \text { (attack), } P<0.001, \\
\mathrm{~W}=20204 \text {; threat, } P<0.001, \mathrm{t}=6.305 \mathrm{df}=48 ; \\
\text { attack, } P<0.001, \mathrm{~W}=94597\end{array}$ & \\
\hline $2 Q$ & $\begin{array}{l}\text { Rattle/rattle (attack) /attack } \\
\text { decoding accuracy in shuffle } \\
\text { and recoding }\end{array}$ & $\begin{array}{l}\text { Mann-Whitney test; } \\
\text { Wilcoxon matched- } \\
\text { pairs signed-rank } \\
\text { test }\end{array}$ & $\begin{array}{llr}33.04 \pm 0.3517 & \text { vs } & 33.64 \pm 0.3405 \\
33.95 \pm 0.3632 & \text { vs } & 41.55 \pm 0.3789 \\
54.69 \pm 0.3811 \text { vs } & 44.93 \pm 0.3632\end{array}$ & $\begin{array}{l}\text { Shuffle vs recoding: Pre, } P<0.001 \text {, } \\
\mathrm{U}=304214 ; \text { Beh, } P<0.001, \mathrm{U}=100653 \text {; } \\
\text { Post, } P<0.001, \mathrm{U}=255098 \text {. Recoding: Pre } \\
v s \text { Beh, } P<0.001, \mathrm{~W}=300581 \text {; Pre } v \text { s post, } \\
P<0.001, \mathrm{~W}=94099\end{array}$ & $\begin{array}{c}1000 / 100 \\
0\end{array}$ \\
\hline 3D & $\begin{array}{l}\text { Peak value of male-male } \\
\text { attack and male-female attack } \\
\text { in GCamp6m Group }\end{array}$ & $\begin{array}{l}\text { Wilcoxon matched- } \\
\text { pairs signed-rank } \\
\text { test; Mann-Whitney } \\
\text { test }\end{array}$ & $\begin{array}{lcr}15.63 \pm 0.9487 & \text { vs } & 23.43 \pm 1.143 \\
22.28 \pm 1.194 & \text { vs } & 14.99 \pm 2.329 \\
25.62 \pm 2.329 & \text { vs } 20.91 \pm 2.625\end{array}$ & $\begin{array}{l}\text { GCamp6m of pre-attack } v s \text { attack in male- } \\
\text { female aggression, } P<0.001, \quad \mathrm{~W}=1616 \text {; } \\
\text { male-female attack } v s \text { male-female attack, } P \\
=0.4071, \mathrm{U}=12834\end{array}$ & $\begin{array}{l}458 / 60 \text { tri } \\
\text { als }\end{array}$ \\
\hline 3G & $\begin{array}{l}\begin{array}{l}\text { Peak value of } \\
\text { attack ande-male } \\
\text { defensive attack in } \\
\text { male-male } \\
\text { Group }\end{array} \\
\end{array}$ & $\begin{array}{l}\text { Wilcoxon matched- } \\
\text { pairs signed-rank } \\
\text { test; Mann-Whitney } \\
\text { test }\end{array}$ & $\begin{array}{llr}15.63 \pm 0.9487 & \text { vs } & 23.43 \pm 1.143 \\
22.28 \pm 1.194 & \text { vs } & 24.56 \pm 0.7408 \\
30.23 \pm 0.7896 & \text { vs } 30.59 \pm 0.8752\end{array}$ & $\begin{array}{l}\text { GCamp6m of pre-attack vs attack in inter- } \\
\text { male defensive aggression, } P<0.001 \text {, } \\
\mathrm{W}=103264 \text {; male-male attack } v s \text { inter-male } \\
\text { defensive attack, } P<0.001, \mathrm{U}=121345\end{array}$ & $\begin{array}{c}458 / 680 \mathrm{t} \\
\text { rials }\end{array}$ \\
\hline $3 \mathrm{~K}$ & $\begin{array}{l}\text { Approach/ approach (attack) } \\
\text { /predatory attack decoding } \\
\text { accuracy in shuffle and } \\
\text { recoding }\end{array}$ & $\begin{array}{l}\text { Mann-Whitney test; } \\
\text { Wilcoxon matched- } \\
\text { pairs signed-rank } \\
\text { test }\end{array}$ & $\begin{array}{lcr}33.18 \pm 0.3709 & \text { vs } & 32.49 \pm 0.3791 \\
33.61 \pm 0.3811 & \text { vs } & 43.59 \pm 0.4010 \\
46.39 \pm 0.3972 \text { vs } & 40.39 \pm 0.38889\end{array}$ & $\begin{array}{l}\text { Shuffle } v s \text { recoding: Pre, } P<0.001 \text {, } \\
\mathrm{U}=277581 ; \text { Beh, } P<0.001, \mathrm{U}=214523 ; \\
\text { Post } P<0.001, \mathrm{U}=348929 . \text { Recoding: Pre } \\
v s \text { Beh, } P=0.001, \mathrm{~W}=70681 ; \text { Pre } v \text { post, } P \\
<0.001, \mathrm{~W}=-80243\end{array}$ & $\begin{array}{c}1000 / 100 \\
0\end{array}$ \\
\hline $3 \mathrm{~L}$ & $\begin{array}{l}\text { Peak value of male-male } \\
\text { attack and predatory attack in } \\
\text { GCamp6m Group }\end{array}$ & Mann-Whitney test & $\begin{array}{lcr}15.63 \pm 0.9487 & \text { vs } & 23.43 \pm 1.143 \\
22.28 \pm 1.194 & \text { vs } & 6.553 \pm 0.4438 \\
8.406 \pm 0.4702 \text { vs } 9.018 \pm 0.5822\end{array}$ & $\begin{array}{l}\text { GCamp6m of pre-attack in male-male } \\
\text { attack } v \text { s predatory attack, } P<0.001 \text {, } \\
\mathrm{U}=26345 \text {; GCampm of attack period in } \\
\text { male-male attack } v s \text { predatory attack, } P< \\
0.001, \mathrm{U}=18607\end{array}$ & $\begin{array}{l}458 / 186 \mathrm{t} \\
\text { rials }\end{array}$ \\
\hline 3P & $\begin{array}{l}\text { Approach/ approach (attack) } \\
\text { /pup-directed attack decoding } \\
\text { accuracy in shuffle and } \\
\text { recoding }\end{array}$ & $\begin{array}{l}\text { Mann-Whitney test; } \\
\text { Wilcoxon matched- } \\
\text { pairs signed-rank } \\
\text { test }\end{array}$ & $\begin{array}{llr}33.38 \pm 0.3756 & \text { vs } & 32.91 \pm 0.3479 \\
33.74 \pm 0.3918 & \text { vs } & 52.81 \pm 0.4142 \\
52.57 \pm 0.4253 & \text { vs } & 50.19 \pm 0.3986\end{array}$ & $\begin{array}{l}\text { Shuffle vs recoding: Pre, } P<0.001 \text {, } \\
\mathrm{U}=139754 ; \text { Beh, } P<0.001, \mathrm{U}=133330 \text {; } \\
\text { Post, } P<0.001, \mathrm{U}=179120 . \text { Recoding: Pre } \\
v s \text { Beh, } P=0.8169, \mathrm{~W}=-3405 ; \text { Pre } v s \text { post, } \\
P<0.001, \mathrm{~W}=-61577\end{array}$ & $\begin{array}{c}1000 / 100 \\
0\end{array}$ \\
\hline $3 Q$ & $\begin{array}{l}\text { Peak value of male-male } \\
\text { attack and pup-directed attack } \\
\text { in GCamp6m Group }\end{array}$ & Mann-Whitney test & $\begin{array}{lrr}15.63 \pm 0.9487 & \text { vs } & 23.43 \pm 1.143 \\
22.28 \pm 1.194 & \text { vs } & 8.804 \pm 0.7489 \\
9.496 \pm 0.8951 \text { vs } 7.116 \pm 0.8026\end{array}$ & $\begin{array}{l}\text { GCamp6m of pre-attack in male-male } \\
\text { attack } v s \text { attack in pup-directed aggression, } \\
P=0.0031 \text {, U }=9140 \text {; male-male attack } v \\
\text { pup-directed attack, } P<0.001, \mathrm{U}=5786\end{array}$ & $\begin{array}{l}458 / 53 \text { tri } \\
\text { als }\end{array}$ \\
\hline $3 \mathbf{U}$ & $\begin{array}{l}\text { Sniff/ sniff (attack) /female- } \\
\text { male attack decoding accuracy } \\
\text { in shuffle and recoding }\end{array}$ & $\begin{array}{l}\text { Mann-Whitney test; } \\
\text { Wilcoxon matched- } \\
\text { pairs signed-rank } \\
\text { test }\end{array}$ & $\begin{array}{llr}33.53 \pm 0.3569 & \text { vs } & 32.93 \pm 0.3262 \\
33.08 \pm 0.3596 & \text { vs } & 37.41 \pm 0.3755 \\
43.35 \pm 0.3773 \text { vs } & 39.87 \pm 0.3682\end{array}$ & $\begin{array}{l}\text { Shuffle } v s \text { recoding: Pre, } P<0.001 \text {, } \\
\mathrm{U}=411334 ; \text { Beh, } P<0.001, \mathrm{U}=257635 \text {; } \\
\text { Post }, P<0.001, \mathrm{U}=341973 \text {. Recoding: Pre } \\
v s \text { Beh, } P<0.001, \mathrm{~W}=154324 \text {; Pre } v s \text { post, } \\
P<0.001, \mathrm{~W}=62653\end{array}$ & $\begin{array}{c}1000 / 100 \\
0\end{array}$ \\
\hline
\end{tabular}


bioRxiv preprint doi: https://doi.org/10.1101/2020.04.22.047670; this version posted February 19, 2021. The copyright holder for this preprint (which was not certified by peer review) is the author/funder, who has granted bioRxiv a license to display the preprint in perpetuity. It is made available under aCC-BY-NC-ND 4.0 International license.

\begin{tabular}{|c|c|c|c|c|c|}
\hline $3 \mathbf{V}$ & $\begin{array}{l}\text { Peak value of male-male } \\
\text { attack and female-male attack } \\
\text { in GCamp6m Group }\end{array}$ & Mann-Whitney test & $\begin{array}{lrrl}15.63 \pm 0.9487 & \text { vs } & 23.43 \pm 1.143 & \text { vs } \\
22.28 \pm 1.194 & \text { vs } & 9.437 \pm 0.4577 & \text { vs } \\
8.758 \pm 0.5132 \text { vs } 12.73 \pm 0.6120 & \end{array}$ & $\begin{array}{l}\text { GCamp6m of pre-attack in male-male } \\
\text { attack } v s \text { attack in female-male aggression, } \\
P<0.001, \mathrm{U}=77784 ; \text { male-male attack } v s \\
\text { female-male attack, } P<0.001, \mathrm{U}=49660\end{array}$ & $\begin{array}{c}458 / 454 \mathrm{t} \\
\text { rials }\end{array}$ \\
\hline $3 \mathbf{W}$ & $\begin{array}{l}\text { GCamp6m Group in } 14 \text { types } \\
\text { of social behaviors, Peak value } \\
\text { of pre-behavior and during } \\
\text { behavior }\end{array}$ & $\begin{array}{l}\text { Wilcoxon matched- } \\
\text { pairs signed-rank } \\
\text { test }\end{array}$ & \multirow{2}{*}{$\begin{array}{lccc}6.354 \pm 1.259 & v s & 4.923 \pm 0.5329 & v s \\
8.406 \pm 0.4702 & v s & 4.496 \pm 1.583 & \text { vs } \\
7.808 \pm 0.8946 & v s & 9.496 \pm 0.8951 & v s \\
7.033 \pm 0.7578 & v s & 7.477 \pm 0.8170 & v s \\
8.758 \pm 0.5132 & v s & 9.902 \pm 0.8186 & v s \\
21.23 \pm 1.811 & v s & 23.43 \pm 1.143 & v s \\
25.62 \pm 2.329 & v s & 30.23 \pm 0.7896 & \end{array}$} & $\begin{array}{l}1-14^{\text {th }}: P=0.7768, \mathrm{~W}=62 ; P=0.0673, \mathrm{~W}=- \\
2220 ; \quad P<0.001, \mathrm{~W}=7191 ; P=0.0228, \\
\mathrm{~W}=-556 ; P=0.0015, \mathrm{~W}=664 ; P=0.1355, \\
\mathrm{~W}=339 ; P=0.0759, \mathrm{~W}=1893 ; P=0.1258, \\
\mathrm{~W}=-1749 ; P=0.0052, \mathrm{~W}=-15649 ; P= \\
0.0404, \mathrm{~W}=7536 ; P<0.001, \mathrm{~W}=11552 ; P \\
<0.001, \mathrm{~W}=63625 ; P<0.001, \mathrm{~W}=1616 ; P \\
<0.001, \mathrm{~W}=103264\end{array}$ & \multirow{4}{*}{$\begin{array}{l}51 / 167 / 1 \\
86 / 56 / 51 \\
153 / 150 / \\
157 / 454 / \\
343 / 236 / \\
458 / 60 / 6 \\
80 \text { trials }\end{array}$} \\
\hline $3 \mathbf{W}$ & $\begin{array}{l}\text { GCamp6m Group in } 14 \text { types } \\
\text { of social behaviors, Peak value } \\
\text { during social behaviors }\end{array}$ & $\begin{array}{l}\text { Kruskal-Wallis test; } \\
\text { Mann-Whitney test }\end{array}$ & & 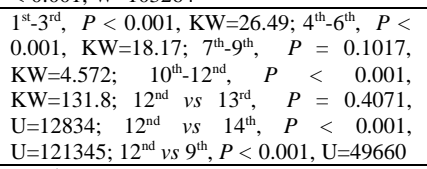 & \\
\hline $3 \mathbf{W}$ & $\begin{array}{l}\text { GCamp6m Group in } 14 \text { types } \\
\text { of social behaviors, Area under } \\
\text { curve per } s \text { of pre-behavior } \\
\text { and during behavior }\end{array}$ & $\begin{array}{l}\text { Wilcoxon matched- } \\
\text { pairs signed-rank } \\
\text { test; Paired t-test; }\end{array}$ & \multirow{2}{*}{ 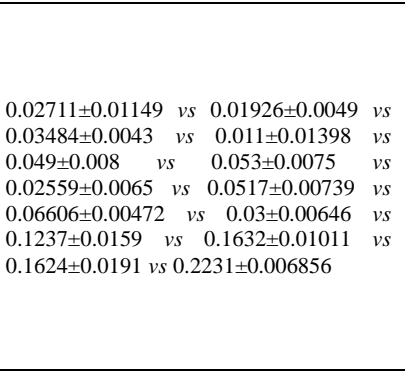 } & $\begin{array}{l}1-14^{\mathrm{th}}: P=0.004, \mathrm{~W}=606 ; \quad P<0.001, \\
\mathrm{~W}=7744 ; \quad P<0.001, \mathrm{~W}=13603 ; P= \\
0.4783, \mathrm{~W}=176 ; P<0.001, \mathrm{~W}=1254 ; P< \\
0.001, \mathrm{t}=4.498 \mathrm{df}=52 ; P=0.008, \mathrm{~W}=2815 ; \\
P<0.001, \mathrm{~W}=6779 ; P<0.001, \mathrm{~W}=16219 ; \\
P=0.0610, \quad \mathrm{~W}=6888 ; P \quad P<0.001, \\
\mathrm{~W}=20204 ; P<0.001, \mathrm{~W}=94597 ; P< \\
0.001, \mathrm{~W}=1754 ; P<0.001, \mathrm{~W}=1664\end{array}$ & \\
\hline $3 \mathbf{W}$ & $\begin{array}{l}\text { GCamp6m Group in } 14 \text { types } \\
\text { of social behaviors, Area under } \\
\text { curve per s }\end{array}$ & $\begin{array}{l}\text { Mann-Whitney test; } \\
\text { Kruskal-Wallis test }\end{array}$ & & 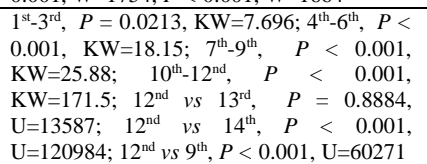 & \\
\hline $4 \mathrm{C}$ & $\begin{array}{l}\text { Pre-CNO vs CNO in mCherry } \\
\text { Group, } \quad \text { Latency(L), } \\
\text { Duration(D), Events(E) }\end{array}$ & $\begin{array}{l}\text { Wilcoxon matched- } \\
\text { pairs signed-rank } \\
\text { test }\end{array}$ & $\begin{array}{llll}\mathrm{L}: & 770.3 \pm 86.62 \text { vs } & 619.2 \pm 158.8 ; \mathrm{D}: \\
0.38 \pm 0.3453 & \text { vs } & 1.595 \pm 1.003 ; \mathrm{E}: \\
0.3333 \pm 0.2108 \text { vs } & 0.8333 \pm 0.4773 .\end{array}$ & $\begin{array}{l}\mathrm{L}: P=0.2500 ; \mathrm{W}=-6.0 ; \mathrm{D}: P=0.2500 ; \\
\mathrm{W}=6.0 ; \mathrm{E}: P=0.5000 ; \mathrm{W}=3 ;\end{array}$ & $6 / 6$ mice \\
\hline $4 \mathrm{C}$ & $\begin{array}{l}\text { Saline vs CNO in mCherry } \\
\text { Group, } \\
\text { Duration(D), Events(E) }\end{array}$ & Paired t-test & $\begin{array}{lll}\mathrm{L}: & 585.2 \pm 149.6 \text { vs } & 619.2 \pm 158.8 ; \mathrm{D}: \\
2.783 \pm 1.676 \text { vs } & 1.595 \pm 1.003 ; \mathrm{E}: \\
1.5 \pm 0.9574 \text { vs } 0.8333 \pm 0.4773 .\end{array}$ & $\begin{array}{l}\mathrm{L}: P=0.7571 ; \mathrm{t}=0.3268, \quad \mathrm{df}=5 ; \mathrm{D}: P= \\
0.1858 ; \quad \mathrm{t}=1.533 \quad \mathrm{df}=5 ; \mathrm{E}: \quad P=0.2856 ; \\
\mathrm{t}=1.195 \mathrm{df}=5 ;\end{array}$ & $6 / 6$ mice \\
\hline $4 \mathrm{C}$ & $\begin{array}{l}\text { Pre-CNO vs CNO in HM3D } \\
\text { Group, } \quad \text { Latency(L), } \\
\text { Duration(D), Events(E) }\end{array}$ & $\begin{array}{l}\text { Wilcoxon matched- } \\
\text { pairs signed-rank } \\
\text { test }\end{array}$ & $\begin{array}{lcrr}\mathrm{L}: & 791 \pm 109 & \text { vs } & 53.26 \pm 12.63 ; \mathrm{D}: \\
1.034 \pm 1.034 & v s & 33.99 \pm 9.798 ; \mathrm{E}: \\
0.5714 \pm 0.5714 \text { vs } & 21.14 \pm 4.93 . \\
\end{array}$ & $\begin{array}{l}\mathrm{L}: P=0.0156 ; \mathrm{W}=-28.0 ; \mathrm{D}: P=0.0156 \\
\mathrm{~W}=28.0 ; \mathrm{E}: P=0.0156 ; \mathrm{W}=28.0\end{array}$ & $7 / 7$ mice \\
\hline $4 \mathrm{C}$ & $\begin{array}{l}\text { Saline } v s \text { CNO in HM3D } \\
\text { Group, } \\
\text { Duration(D), Events(E) }\end{array}$ & $\begin{array}{l}\text { Wilcoxon matched- } \\
\text { pairs signed-rank } \\
\text { test }\end{array}$ & $\begin{array}{l}\text { L: } 797.1 \pm 102.9 \text { vs } 53.26 \pm 12.63 ; \mathrm{D}: \\
1.927 \pm 1.927 \text { vs } 33.99 \pm 9.798 ; \mathrm{E}: \\
1.286 \pm 1.286 \text { vs } 21.14 \pm 4.93 .\end{array}$ & $\begin{array}{l}\mathrm{L}: P=0.0156 ; \mathrm{W}=-28.0 ; \mathrm{D}: P=0.0156 \\
\mathrm{~W}=28.0 ; \mathrm{E}: P=0.0156 ; \mathrm{W}=28.0\end{array}$ & $7 / 7$ mice \\
\hline 4I & $\begin{array}{l}\text { Pre } v s \text { Laser } v s \text { Post in ChR2 } \\
\text { Group, Possibility of trials } \\
\text { showing aggression(P), } \\
\text { Latency(L), Duration(D), } \\
\text { Events(E) }\end{array}$ & Friedman test & $\begin{array}{l}\text { P: } 0 \pm 0 \text { vs } 93.85 \pm 3.497 \text { vs } 1.538 \pm 1.538 ; \mathrm{L}: \\
15 \pm 0 \text { vs } 2.512 \pm 0.5046 \text { vs } 14.84 \pm 0.1611 ; \mathrm{D}: \\
0 \pm 0 \text { vs } 3.695 \pm 0.5748 \text { vs } 0.018 \pm 0.018 ; \mathrm{E}: \\
0 \pm 0 \text { vs } 1.498 \pm 0.1956 \text { vs } 0.01538 \pm 0.01538\end{array}$ & $\begin{array}{l}\text { P: } P<0.001 ; \mathrm{FM}=25.40 ; \mathrm{L}: P<0.001 ; \\
\mathrm{FM}=25.40 ; \mathrm{D}: P<0.001 ; \mathrm{FM}=25.40 ; \mathrm{E}: P \\
<0.001 ; \mathrm{FM}=25.40 ;\end{array}$ & 13 mice \\
\hline 4I & $\begin{array}{l}\text { Laser in EYFP and ChR2 } \\
\text { Group, Possibility of trials } \\
\text { showing } \\
\text { Latency(L), aggression(P), } \\
\text { Events(E) }\end{array}$ & Mann-Whitney test & $\begin{array}{l}\mathrm{P}: 0 \pm 0 \text { vs } 93.85 \pm 3.497 ; \quad \mathrm{L}: \quad 15 \pm 0 \text { vs } \\
2.512 \pm 0.5046 ; \mathrm{D}: 0 \pm 0 \text { vs } 3.695 \pm 0.5748 ; \mathrm{E}: \\
0 \pm 0 \text { vs } 1.498 \pm 0.1956\end{array}$ & $\begin{array}{l}\text { P: } P<0.001 ; \mathrm{U}=0 ; \mathrm{L}: P<0.001 ; \mathrm{U}=0 \text {;D: } \\
P<0.001 ; \mathrm{U}=0 ; \mathrm{E}: P<0.001 ; \mathrm{U}=0\end{array}$ & $\begin{array}{l}6 / 13 \\
\text { mice }\end{array}$ \\
\hline $4 \mathrm{M}$ & $\begin{array}{l}\text { Pre } v s \text { Laser } v s \text { Post in ChR2 } \\
\text { Group, Normalized pupil size }\end{array}$ & Friedman test & $\begin{array}{llll}0.9953 \pm 0.003685 & \text { vs } & 1.286 \pm 0.071 & \text { vs } \\
1.151 \pm 0.05884 & & & \\
\end{array}$ & 16.22 & 9 mice \\
\hline $4 \mathbf{N}$ & $\begin{array}{l}\text { Pre } v s \text { Laser } v s \text { Post in ChR2 } \\
\text { Group, Normalized eye size }\end{array}$ & $\begin{array}{l}\text { Repeated one-way } \\
\text { ANOVA }\end{array}$ & $1 \pm 0$ vs $1.037 \pm 0.0172$ vs $0.999 \pm 0.01009$ & $0357 ; \mathrm{F}(1.398,11.19)=5.102$ & 9 mice \\
\hline 40 & $\begin{array}{l}\text { Pre } v s \text { Laser } v s \text { Post in ChR2 } \\
\text { Group, Normalized breathing } \\
\text { rate }\end{array}$ & $\begin{array}{l}\text { Repeated one-way } \\
\text { ANOVA }\end{array}$ & $1 \pm 0$ vs $1.076 \pm 0.02183$ vs $1.028 \pm 0.007836$ & $P=0.0136 ; \mathrm{F}(1.186,9.490)=8.515$ & 9 mice \\
\hline $\mathbf{4 P}$ & $\begin{array}{l}\text { Pre } v s \text { Laser } v s \text { Post in ChR2 } \\
\text { Group, Normalized heart rate }\end{array}$ & $\begin{array}{l}\text { Repeated one-way } \\
\text { ANOVA }\end{array}$ & $1 \pm 0$ vs $1.068 \pm 0.01586$ vs $1.006 \pm 0.02477$ & $P=0.0447 ; \mathrm{F}(1.426,9.979)=4.744$ & 8 mice \\
\hline $4 Q$ & $\begin{array}{l}\text { Pre } v s \text { Laser } v s \text { Post in ChR2 } \\
\text { Group, trembling time }\end{array}$ & $\begin{array}{l}\text { Repeated one-way } \\
\text { ANOVA }\end{array}$ & $\begin{array}{llll}0.4078 \pm 0.1478 & \text { vs } & 2.427 \pm 0.4445 & \text { vs } \\
0.4171 \pm 0.1638 & & & \end{array}$ & $P=0.0019 ; \mathrm{F}(1.201,9.608)=16.21$ & 9 mice \\
\hline $5 \mathrm{C}$ & $\begin{array}{l}\text { Pre } v s \text { Laser } v s \text { Post in ChR2 } \\
\text { Group, Possibility of trials } \\
\text { showing } \quad \text { aggression(P), } \\
\text { Latency(L), Duration(D), } \\
\text { Events(E) }\end{array}$ & Friedman test & $\begin{array}{lrrrr}\mathrm{P}: & 1.154 \pm 1.154 & \text { vs } & 79.00 \pm 9.713 & v s \\
0.7692 \pm 0.7692 ; \mathrm{L}: & 14.93 \pm 0.0686 & v s \\
4.404 \pm 1.449 & \text { vs } & 15 \pm 0 ; \mathrm{D}: & 0.0188 \pm 0.0188 \\
\text { vs } & 2.884 \pm 0.9603 & \text { vs } & 0.00 \pm 0.00 ; \mathrm{E}: \\
0.02 \pm 0.02 & \text { vs } & 1.845 \pm 0.2477 & v s & 0.00 \pm 0.00\end{array}$ & $\begin{array}{l}\text { P: } P<0.001 ; \mathrm{FM}=19.42 ; \mathrm{L}: P<0.001 ; \\
\text { FM= 19.42;D: } P<0.001 ; \mathrm{FM}=19.42 ; \mathrm{E}: P \\
<0.001 ; \mathrm{FM}=19.42\end{array}$ & 10 mice \\
\hline $5 \mathbf{E}$ & $\begin{array}{l}\text { Pre } v s \text { Laser } v s \text { Post in ChR2 } \\
\text { Group, Possibility of trials } \\
\text { showing aggression }(\mathrm{P}) \text {, } \\
\text { Latency }(\mathrm{L})\end{array}$ & Friedman test & 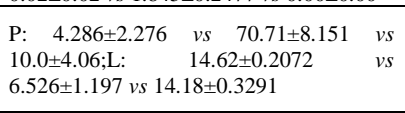 & $\begin{array}{l}\text { P: } P<0.001 ; \mathrm{FM}=26.53 ; \mathrm{L}: P<0.001 \\
\mathrm{FM}=25.40\end{array}$ & 14 mice \\
\hline 5G & $\begin{array}{l}\text { Pre } v s \text { Laser } v s \text { Post in ChR2 } \\
\text { Group, Possibility of trials } \\
\text { showing } \quad \text { aggression(P), } \\
\text { Latency(L), Duration(D), } \\
\text { Events(E) }\end{array}$ & Friedman test & $\begin{array}{l}\text { P: } 0 \pm 0 \text { vs } 73.33 \pm 14.3 \text { vs } 4.762 \pm 4.762 ; \mathrm{L}: \\
15 \pm 0 \text { vs } 5.611 \pm 1.793 \text { vs } 14.67 \pm 0.2147 ; \mathrm{D} \text { : } \\
0.00 \pm 0.00 \quad \text { vs } \quad 3.255 \pm 0.9358 \quad \text { vs } \\
0.06214 \pm 0.06214 ; \mathrm{E}: \quad 0.00 \pm 0.00 \quad \text { vs } \\
1.377 \pm 0.3448 \text { vs } 0.04762 \pm 0.04762\end{array}$ & $\begin{array}{l}\mathrm{P}: P=0.0041 ; \mathrm{FM}=11.47 ; \mathrm{L}: P=0.0021 \\
\mathrm{FM}=11.20 ; \mathrm{D}: P=0.0041 ; \mathrm{FM}=11.47 ; \mathrm{E}: P \\
=0.0041 ; \mathrm{FM}=11.47\end{array}$ & 6 mice \\
\hline 5I & $\begin{array}{l}\text { Pre vs Laser vs Post in ChR2 } \\
\text { Group, Possibility of trials } \\
\text { showing aggression(P), } \\
\text { Latency(L), Duration(D), } \\
\text { Events(E) }\end{array}$ & $\begin{array}{lr}\text { Friedman } & \text { test; } \\
\text { Repeated } & \text { one-way } \\
\text { ANOVA } & \end{array}$ & $\begin{array}{llrr}\text { P: } 17.57 \pm 8.118 & v s & 89.14 \pm 4.554 & v s \\
11.67 \pm 7.265 ; \mathrm{L}: & & 12.07 \pm 1.369 & v s \\
2.498 \pm 0.7538 & v s & 13.69 \pm 0.9331 ; \mathrm{D}: \\
0.0765 \pm 0.03467 & v s & 2.904 \pm 0.8344 & \text { vs } \\
0.1625 \pm 0.1545 ; \mathrm{E}: 0.25 \pm 0.1118 & v s \\
2.633 \pm 0.6217 \text { vs } 0.25 \pm 0.1936 & \end{array}$ & $\begin{array}{l}\mathrm{P}: P=0.0123 ; \mathrm{FM}=8.444 ; \mathrm{L}: P=0.0009 \\
\mathrm{~F}(1.677,6.707)=25.61 ; \mathrm{D}: P=0.0180 ; \mathrm{F} \\
(1.007,5.033)=11.89 ; \mathrm{E}: P=0.0140 ; \mathrm{F} \\
(1.199,4.798)=13.53 .\end{array}$ & 5 mice \\
\hline
\end{tabular}


bioRxiv preprint doi: https://doi.org/10.1101/2020.04.22.047670; this version posted February 19, 2021. The copyright holder for this preprint (which was not certified by peer review) is the author/funder, who has granted bioRxiv a license to display the preprint in perpetuity. It is made available under aCC-BY-NC-ND 4.0 International license.

\begin{tabular}{|c|c|c|c|c|c|}
\hline \multirow{2}{*}{$\begin{array}{l}\mathbf{5 J} \\
\mathbf{5 J} .2 \mathrm{n} \\
\mathrm{d}\end{array}$} & \multirow{2}{*}{$\begin{array}{l}\text { Pre } v s \text { Laser } v s \text { Post in ChR2 } \\
\text { Group, Possibility of trials } \\
\text { showing aggression }\end{array}$} & \multirow{2}{*}{$\begin{array}{l}\text { Repeated one-way } \\
\text { ANOVA } \\
\text { Friedman test }\end{array}$} & \multicolumn{2}{|c|}{$\begin{array}{l}\text { Value of the } 1-13 \text { column: } 93.9 \pm 3.5 \text { vs } 85.7 \pm 5.1 \text { vs } 70.8 \pm 7.6 \text { vs } 86.1 \pm 5.9 \text { vs } 84.0 \pm \\
16.0 \text { vs } 80.0 \pm 6.3 \text { vs } 98.2 \pm 1.8 \text { vs } 79.0 \pm 9.7 \text { vs } 88.0 \pm 12.0 \text { vs } 70.7 \pm 8.2 \text { vs } 73.3 \pm 14.3 \text { vs } \\
89.1 \pm 4.6 \text { vs } 92.8 \pm 2.4(\%) . P: P=0.1170 ; \mathrm{F}(12,93)=1.664\end{array}$} & \multirow{2}{*}{$\begin{array}{c}13 / 7 / 7 / 6 / \\
5 / 5 / 11 / 1 \\
0 / 5 / 14 / 6 / \\
5 / 12 \\
\text { mice } \\
\\
7 \text { mice }\end{array}$} \\
\hline & & & $\begin{array}{llll}1.786 \pm 1.786 & v s & 85.71 \pm 5.050 & v s \\
8.929 \pm 5.923 & & & \end{array}$ & $P=0.0007 ; \mathrm{FM}=13.13$ & \\
\hline 5J.3rd & $\begin{array}{l}\text { Pre } v s \text { Laser } v s \text { Post in ChR2 } \\
\text { Group, Possibility of inter- } \\
\text { male aggression in residents' } \\
\text { cage }\end{array}$ & Friedman test & $0.00 \pm 0.00$ vs $70.83 \pm 7.553$ vs $1.786 \pm 7.786$ & $P=0.0014 ; \mathrm{FM}=13.45$ & 7 mice \\
\hline $\mathbf{5 J} .4$ th & $\begin{array}{l}\text { Pre } v s \text { Laser } v s \text { Post in ChR2 } \\
\text { Group, Possibility of inter- } \\
\text { male aggression versus cage } \\
\text { mate }\end{array}$ & Friedman test & $0.00 \pm 0.00$ vs $86.11 \pm 5.927$ vs $0.00 \pm 0.00$ & $P=0.0041 ; \mathrm{FM}=12.00$ & 6 mice \\
\hline 5J.5th & $\begin{array}{l}\text { Pre } v s \text { Laser } v s \text { Post in ChR2 } \\
\text { Group, Possibility of inter- } \\
\text { male aggression in singly mice }\end{array}$ & Friedman test & $6.19 \pm 3.81$ vs $84.0 \pm 16.0$ vs $5.714 \pm 5.714$ & $P=0.0123 ; \mathrm{FM}=8.824$ & 5 mice \\
\hline 5J.6th & $\begin{array}{l}\text { Pre } v s \text { Laser } v s \text { Post in ChR2 } \\
\text { Group, Possibility of inter- } \\
\text { male aggression in singly } \\
\text { mice, in novel cage }\end{array}$ & Friedman test & $0 \pm 0$ vs $80 \pm 6.325$ vs $3.333 \pm 3.333$ & $P=0.0123 ; \mathrm{FM}=9.500$ & 5 mice \\
\hline 5J.7th & $\begin{array}{l}\text { Pre } v s \text { Laser } v s \text { Post in ChR2 } \\
\text { Group, Possibility of male- } \\
\text { female aggression }\end{array}$ & Friedman test & $1.299 \pm 1.299$ vs $98.2 \pm 1.8$ vs $1.299 \pm 1.299$ & $P<0.001 ; \mathrm{FM}=22.00$ & 11 mice \\
\hline 5J.9th & $\begin{array}{l}\text { Pre } v s \text { Laser } v s \text { Post in ChR2 } \\
\text { Group, Possibility of female- } \\
\text { female aggression }\end{array}$ & Friedman test & $0 \pm 0$ vs $88 \pm 12$ vs $0 \pm 0$ & $P=0.0123 ; \mathrm{FM}=10.00$ & 5 mice \\
\hline $\begin{array}{l}\mathbf{5 J} .13 \mathrm{r} \\
\mathrm{d}\end{array}$ & $\begin{array}{l}\text { Pre } v s \text { Laser } v s \text { Post in ChR2 } \\
\text { Group, Possibility of predatory } \\
\text { aggression }\end{array}$ & Friedman test & $0.00 \pm 0.00$ vs $92.81 \pm 2.412$ vs $22.76 \pm 4.482$ & $P<0.001 ; \mathrm{FM}=23.13$ & 12 mice \\
\hline 6D & $\begin{array}{l}\text { Possibility of inter-male } \\
\text { aggression during } 14 \\
\text { intensities of laser stimulation }\end{array}$ & $\begin{array}{l}\text { Non-Linear } \\
\text { regression: } \\
\text { Sigmoidal fit, 4PL } \\
\text { (laser power) }\end{array}$ & $\begin{array}{l}0,0.03,0.10,0.17,0.26,0.34,0.40,0.68 \\
1.17,1.58,1.98,2.24,2.70, \text { and } 2.98 \mathrm{~mW} \\
\text { laser power were used in inter-male } \\
\text { aggression; }\end{array}$ & $\begin{array}{l}\text { Goodness of Fit: } \mathrm{R}^{2} \text { (during stimulation) }= \\
0.7494, \mathrm{R}^{2} \text { (before stimulation) }=1 \\
\text { HillSlope (during stimulation) }=1.545\end{array}$ & $\begin{array}{l}84 \text { trials, } \\
6 \text { mice }\end{array}$ \\
\hline $6 \mathbf{F}$ & $\begin{array}{l}\text { Possibility of } 5 \text { types of } \\
\text { aggression during } 14 \\
\text { intensities of laser stimulation }\end{array}$ & $\begin{array}{l}\text { Non-Linear } \\
\text { regression: } \\
\text { Sigmoidal fit, 4PL } \\
\text { (laser power) }\end{array}$ & $\begin{array}{l}\text { HillSlope } \text { (inter-male) }=1.545 ; \text { HillSlope } \\
\text { (male-female })=0.9962 ; \text { Hillslope } \\
\text { (female-male })=0.5883 ; \text { HillSlope } \\
\text { (infanticide })=3.121 ; \text { HillSlope } \\
\text { (predation) }=4.985\end{array}$ & $\begin{array}{l}\mathrm{R}^{2}(\text { inter-male })=0.7494 ; \mathrm{R}^{2}(\text { male-female }) \\
=0.7247 ; \mathrm{R}^{2}(\text { female-male })=0.4265 ; \mathrm{R}^{2} \\
\text { (infanticide) }=0.8191 ; \mathrm{R}^{2}(\text { predation })= \\
0.9295\end{array}$ & $\begin{array}{l}84 / 84 / 70 \\
/ 84 / 84 \\
\text { trials }\end{array}$ \\
\hline 6G & $\begin{array}{l}\text { Latency to attack onset of } 5 \\
\text { types of aggression during } 14 \\
\text { intensities of laser stimulation }\end{array}$ & $\begin{array}{l}\text { Non-Linear } \\
\text { regression: } \\
\text { Sigmoidal fit, 4PL } \\
\text { (laser power) }\end{array}$ & $\begin{array}{l}\text { HillSlope (inter-male) }=-1.347 ; \text { HillSlope } \\
\text { (male-female) }=-1.072 ; \text { HillSlope } \\
\text { (female-male) }=-0.6046 ; \text { HillSlope } \\
\text { (infanticide) }=-2.873 ; \text { HillSlope } \\
\text { (predation) }=-3.520\end{array}$ & $\begin{array}{l}\mathrm{R}^{2}(\text { inter-male })=0.7416 ; \mathrm{R}^{2}(\text { male-female }) \\
=0.7588 ; \mathrm{R} 2(\text { female-male })=0.4385 ; \mathrm{R}^{2} \\
\text { (infanticide) }=0.7796 ; \mathrm{R}^{2}(\text { predation })= \\
0.8959\end{array}$ & $\begin{array}{l}84 / 84 / 70 \\
/ 84 / 84 \\
\text { trials }\end{array}$ \\
\hline $6 \mathrm{H}$ & 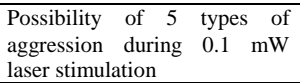 & Kruskal-Wallis test & $\begin{array}{llll}6.667 \pm 6.667 \quad v s & 43.33 \pm 10.85 & v s \\
44.00 \pm 16.00 \quad v s & 85.55 \pm 5.209 & v s \\
96.67 \pm 3.333(\%) & & \end{array}$ & $P<0.001, \mathrm{KW}=21.59$ & $\begin{array}{l}6 / 6 / 5 / 6 / 6 \\
\text { mice }\end{array}$ \\
\hline $6 \mathrm{H}$ & $\begin{array}{l}\text { Latency to attack onset of } 5 \\
\text { types of aggression during } 0.1 \\
\text { mW laser stimulation }\end{array}$ & Kruskal-Wallis test & $\begin{array}{lccc}14.073 \pm 0.927 & v s & 9.076 \pm 1.525 & v s \\
9.125 \pm 2.231 & v s & 3.720 \pm 0.895 & v s \\
2.158 \pm 0.428(\mathrm{~s}) & & & \\
\end{array}$ & $P<0.001, \mathrm{KW}=19.74$ & $\begin{array}{l}6 / 6 / 5 / 6 / 6 \\
\text { mice }\end{array}$ \\
\hline 7C & $\begin{array}{l}\text { mCherry Group, Latency to } \\
\text { attack }\end{array}$ & $\begin{array}{l}\text { Wilcoxon matched- } \\
\text { pairs signed-rank } \\
\text { test and Paired t-test }\end{array}$ & $\begin{array}{l}\text { Pre-saline vs Saline } v s \text { Pre-CNO vs CNO: } \\
209.3 \pm 53.75 \quad \text { vs } 83.69 \pm 36.81 \quad \text { vs } \\
285.6 \pm 79.49 \text { vs } 126.2 \pm 53.31\end{array}$ & $\begin{array}{l}\text { Pre-saline vs Saline: } P=0.0625 \mathrm{~W}=-19.0 \text {; } \\
\text { Pre-CNO vs CNO: } P=0.0836 \mathrm{t}=2.156 \\
\mathrm{df}=5 \text {; Saline vs CNO: } P=0.4814 \mathrm{t}=0.7603 \\
\mathrm{df}=5 \text {; }\end{array}$ & $\begin{array}{l}\text { 6/6/6/6m } \\
\text { ice }\end{array}$ \\
\hline 7C & $\begin{array}{l}\text { HM4D Group, Latency to } \\
\text { attack }\end{array}$ & $\begin{array}{l}\text { Wilcoxon matched- } \\
\text { pairs signed-rank } \\
\text { test and Paired t-test }\end{array}$ & $\begin{array}{l}\text { Pre-saline vs Saline vs Pre-CNO vs CNO: } \\
56.91 \pm 38.25 \text { vs } 187 \pm 89.83 \text { vs } 118.2 \pm 68.1 \\
\text { vs } 900 \pm 0\end{array}$ & $\begin{array}{l}\text { Pre-saline vs Saline: } P=0.0313 \\
\mathrm{~W}=21.0 ; \text { Pre-CNO vs CNO: } P<0.001 \\
\mathrm{t}=11.48 \mathrm{df}=5 \text {; Saline vs CNO: } P<0.001 \\
\mathrm{t}=7.937 \mathrm{df}=5 \text {; }\end{array}$ & $\begin{array}{l}6 / 6 / 6 / 6 \mathrm{~m} \\
\text { ice }\end{array}$ \\
\hline 7C & $\begin{array}{l}\text { mCherry Group, Duration of } \\
\text { attack }\end{array}$ & $\begin{array}{l}\text { Wilcoxon matched- } \\
\text { pairs signed-rank } \\
\text { test }\end{array}$ & $\begin{array}{l}\text { Pre-saline vs Saline } v s \text { Pre-CNO vs CNO: } \\
21.23 \pm 15.03 \text { vs } 15.96 \pm 10.84 \quad \text { vs } \\
21.02 \pm 11.57 \text { vs } 11.61 \pm 5.644\end{array}$ & $\begin{array}{l}\text { Pre-saline vs Saline: } P=0.2188 \mathrm{~W}=-13 \\
\text { Pre-CNO vs CNO: } P=0.4375 \mathrm{~W}=-9.000 \\
\text { Saline } v s \text { CNO: } P=0.3125 \mathrm{~W}=-11.00\end{array}$ & $\begin{array}{l}6 / 6 / 6 / 6 \\
\text { mice }\end{array}$ \\
\hline 7C & $\begin{array}{l}\text { HM4D Group, Duration of } \\
\text { attack }\end{array}$ & $\begin{array}{l}\text { Wilcoxon matched- } \\
\text { pairs signed-rank } \\
\text { test and Paired t-test }\end{array}$ & $\begin{array}{l}\text { Pre-saline vs Saline } v s \text { Pre-CNO vs CNO: } \\
39.19 \pm 13.11 \quad \text { vs } \quad 26.75 \pm 10.78 \quad \text { vs } \\
25.83 \pm 7.395 \text { vs } 0 \pm 0\end{array}$ & $\begin{array}{l}\text { Pre-saline vs Saline: } P=0.2188 \mathrm{~W}=-13.00 \text {; } \\
\text { Pre-CNO vs CNO: } P=0.0174 \mathrm{t}=3.493 \\
\mathrm{df}=5 \text {; Saline vs CNO: } P=0.0313 \mathrm{~W}=- \\
21.00 \text {; }\end{array}$ & $\begin{array}{l}6 / 6 / 6 / 6 \\
\text { mice }\end{array}$ \\
\hline 7C & $\begin{array}{l}\text { mCherry Group, Events of } \\
\text { attack }\end{array}$ & $\begin{array}{l}\text { Wilcoxon matched- } \\
\text { pairs signed-rank } \\
\text { test and Paired t-test }\end{array}$ & $\begin{array}{l}\text { Pre-saline vs Saline vs Pre-CNO vs CNO: } \\
19 \pm 3.464 \text { vs } 17 \pm 3.54 \text { vs } 23.17 \pm 8.784 \text { vs } \\
20.17 \pm 4.086\end{array}$ & $\begin{array}{l}\text { Pre-saline vs Saline: } P=0.5907 \mathrm{t}=0.5742 \\
\mathrm{df}=5 \text {; Pre-CNO vs CNO: } P=0.999 \\
\mathrm{~W}=1.000 \text {; Saline vs CNO: } P=0.5931 \mathrm{t}= \\
0.5703 \mathrm{df}=5 \text {; }\end{array}$ & $\begin{array}{l}6 / 6 / 6 / 6 \\
\text { mice }\end{array}$ \\
\hline $7 \mathrm{C}$ & $\begin{array}{l}\text { HM4D Group, Events of } \\
\text { attack }\end{array}$ & Paired t-test & $\begin{array}{l}\text { Pre-saline vs Saline } v s \text { Pre-CNO vs CNO: } \\
16.83 \pm 5.712 \quad \text { vs } \\
\text { vs } 18.67 \pm 5.175 \text { vs } 0 \pm 0\end{array}$ & $\begin{array}{l}\text { Pre-saline vs Saline: } P=0.0978 \mathrm{t}=2.033 \\
\mathrm{df}=5 \text {; Pre-CNO vs CNO: } P=0.0154 \\
\mathrm{t}=3.607 \mathrm{df}=5 \text {; Saline } \text { vs CNO: } P=0.011 \\
\mathrm{t}=3.941 \mathrm{df}=5 \text {; }\end{array}$ & $\begin{array}{l}6 / 6 / 6 / 6 \\
\text { mice }\end{array}$ \\
\hline $7 \mathbf{E}$ & $\begin{array}{l}\text { HM4D Group, Latency to } \\
\text { mount onset }\end{array}$ & Paired t-test & $\begin{array}{l}\text { Pre-saline vs Saline vs Pre-CNO vs CNO: } \\
156.5 \pm 12.88 \quad \text { vs } \quad 106.8 \pm 26.11 \text { vs } \\
109.3 \pm 24.49 \text { vs } 131 \pm 40.03\end{array}$ & $\begin{array}{l}\text { Pre-saline vs Saline: } P=0.1658 \mathrm{t}=1.621 \\
\mathrm{df}=5 \text {; Pre-CNO vs CNO: } P=0.5014 \\
\mathrm{t}=11.48 \mathrm{df}=5 \text {; Saline vs } \mathrm{CNO}: P=0.325 \\
\mathrm{t}=1.091 \mathrm{df}=5 \text {; }\end{array}$ & $\begin{array}{l}6 / 6 / 6 / 6 \mathrm{~m} \\
\text { ice }\end{array}$ \\
\hline $7 \mathbf{E}$ & HM4D Group, mount duration & Paired t-test & 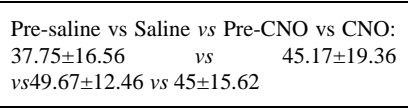 & $\begin{array}{l}\text { Pre-saline vs Saline: } P=0.509 \mathrm{t}=0.7107 \\
\mathrm{df}=5 \text {; Pre-CNO vs CNO: } P=0.4764 \mathrm{t}= \\
0.7695 \mathrm{df}=5 \text {; Saline vs CNO: } P=0.9901 \mathrm{t}= \\
0.01310 \mathrm{df}=5 \text {; }\end{array}$ & $\begin{array}{l}6 / 6 / 6 / 6 \mathrm{~m} \\
\text { ice }\end{array}$ \\
\hline $7 \mathbf{E}$ & HM4D Group, mount events & Paired t-test & $\begin{array}{l}\text { Pre-saline vs Saline } v s \text { Pre-CNO vs CNO: } \\
11.67 \pm 4.529 \text { vs } 10.5 \pm 3.085 \text { vs } 15 \pm 3.044 \text { vs }\end{array}$ & $\begin{array}{l}\text { Pre-saline vs Saline: } P=0.6598 \mathrm{t}=0.4675 \\
\mathrm{df}=5 \text {; Pre-CNO vs CNO: } P=0.603 \mathrm{t}=\end{array}$ & $\begin{array}{c}6 / 6 / 6 / 6 \mathrm{~m} \\
\text { ice }\end{array}$ \\
\hline
\end{tabular}


bioRxiv preprint doi: https://doi.org/10.1101/2020.04.22.047670; this version posted February 19, 2021. The copyright holder for this preprint (which was not certified by peer review) is the author/funder, who has granted bioRxiv a license to display the preprint in perpetuity. It is made available under aCC-BY-NC-ND 4.0 International license.

\begin{tabular}{|c|c|c|c|c|c|c|c|c|}
\hline & & & $13.67 \pm 3.721$ & & & & $\begin{array}{l}0.5547 \mathrm{df}=5 ; \text { Saline vs CNO: } P=0.2858 \\
\mathrm{t}=1.195 \mathrm{df}=5 \text {; }\end{array}$ & \\
\hline $7 \mathrm{M}$ & $\begin{array}{l}v s \text { social male, Attack duration } \\
\text { of the pre-laser, laser and post- } \\
\text { laser phase }\end{array}$ & Friedman test & $\begin{array}{l}3.394 \pm 0.4378 \\
0.8136 \pm 0.4251\end{array}$ & $v s$ & $1.356 \pm 0.2270$ & & $P=0.0179 ; \mathrm{FM}=7.750$ & 8 mice \\
\hline $7 \mathrm{M}$ & $\begin{array}{l}\text { vs pups, Attack duration of the } \\
\text { pre-laser, laser and post-laser } \\
\text { phase }\end{array}$ & Friedman test & $\begin{array}{l}3.626 \pm 1.025 \\
1.084 \pm 0.6395\end{array}$ & vs & $1.575 \pm 0.3004$ & & $P=0.0120 ; \mathrm{FM}=8.333$ & 6 mice \\
\hline $7 \mathrm{M}$ & $\begin{array}{l}v s \text { crickets, Attack duration of } \\
\text { the pre-laser, laser and post- } \\
\text { laser phase }\end{array}$ & Friedman test & $\begin{array}{l}11.70 \pm 0.8476 \\
10.14 \pm 0.7384\end{array}$ & $v s$ & $5.383 \pm 0.7261$ & & $P=0.0046 ; \mathrm{FM}=8$ & 4 mice \\
\hline $7 \mathrm{~N}$ & $\begin{array}{l}\text { Possibility of attack trials } \\
\text { interrupted within } 3 \mathrm{~s}\end{array}$ & Kruskal-Wallis test & $\begin{array}{l}98.44 \pm 1.563 \\
92.86 \pm 7.143 \\
\end{array}$ & $v s$ & $94.87 \pm 5.128$ & & $P=0.8824 ; \mathrm{KW}=0.3672$ & $\begin{array}{l}8 / 6 / 4 \\
\text { mice }\end{array}$ \\
\hline S2H & $\begin{array}{l}\text { EYFP and GCamp6m Group, } \\
\text { Area under curve per s }\end{array}$ & $\begin{array}{l}\text { Mann-Whitney test; } \\
\text { Wilcoxon matched- } \\
\text { pairs signed-rank } \\
\text { test }\end{array}$ & $\begin{array}{l}0.0008 \pm 0.0012 \\
0.0027 \pm 0.0048 \\
0.1632 \pm 0.01011\end{array}$ & 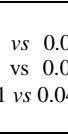 & $\begin{array}{l}00153 \pm 0.0029 v \\
02327 \pm 0.004659 \\
04729 \pm 0.008616\end{array}$ & & $\begin{array}{l}\text { GCamp6m vs EYFP (pre: } P=0.0626, \\
\mathrm{U}=12132 \text {; attack: } P<0.001, \mathrm{U}=3936 \text {; post: } \\
P<0.001, \mathrm{U}=9756 \text { ); GCamp6m: pre } v s \\
\text { attack, } P<0.001, \mathrm{~W}=94597 \text {; pre } v \text { s post, } P \\
<0.001, \mathrm{~W}=20517\end{array}$ & $\begin{array}{l}62 / 458 \text { tri } \\
\text { als }\end{array}$ \\
\hline S2H & $\begin{array}{l}\text { EYFP and GCamp6m Group, } \\
\text { Peak value }\end{array}$ & $\begin{array}{l}\text { Mann-Whitney test; } \\
\text { Wilcoxon matched- } \\
\text { pairs signed-rank } \\
\text { test }\end{array}$ & $\begin{array}{l}2.000 \pm 0.2249 \\
3.672 \pm 0.6622 \\
23.43 \pm 1.143 v s\end{array}$ & $\begin{array}{c}v s \\
v s \\
22.28 \pm\end{array}$ & $\begin{array}{l}2.523 \pm 0.5819 \\
15.63 \pm 0.9487 \\
\pm 1.194\end{array}$ & $\begin{array}{l}v s \\
v s\end{array}$ & $\begin{array}{l}\text { GCamp6m vs EYFP (pre: } P<0.001 \text {, } \\
\mathrm{U}=4460 \text {; attack: } P<0.001, \mathrm{U}=3593 \text {; post: } \\
P<0.001, \mathrm{U}=4659 \text { ); GCamp6m: pre vs } \\
\text { attack, } P<0.001, \mathrm{~W}=63625 ; \text { pre } v \text { s post, } P \\
<0.001, \mathrm{~W}=41623\end{array}$ & $\begin{array}{l}62 / 458 \text { tri } \\
\text { als }\end{array}$ \\
\hline S2N & $\begin{array}{l}\text { EYFP and GCamp6m Group, } \\
\text { Peak value in single attacks }\end{array}$ & $\begin{array}{l}\text { Mann-Whitney test; } \\
\text { Wilcoxon matched- } \\
\text { pairs signed-rank } \\
\text { test }\end{array}$ & $\begin{array}{l}2.183 \pm 0.3090 \\
4.347 \pm 0.9432 \\
28.07 \pm 2.483 v s\end{array}$ & $\begin{array}{c}v s \\
v s \\
22.30 \pm\end{array}$ & $\begin{aligned} & 3.482 \pm 0.9341 \\
& 15.27 \pm 2.071 \\
&+2.491\end{aligned}$ & $\begin{array}{l}v s \\
v s\end{array}$ & $\begin{array}{l}\text { GCamp6m vs EYFP (pre: } P<0.001, \\
\mathrm{U}=918 \text {; attack: } P<0.001, \mathrm{U}=629 \text {; post: } P< \\
0.001, \mathrm{U}=1353 \text { ); GCamp6m: pre } v s \text { attack, } \\
P<0.001, \mathrm{~W}=12001\end{array}$ & $\begin{array}{l}41 / 165 \text { tri } \\
\text { als }\end{array}$ \\
\hline S2N & $\begin{array}{l}\text { EYFP and GCamp6m Group, } \\
\text { Peak value in first attacks }\end{array}$ & $\begin{array}{l}\text { Unpaired t-test; } \\
\text { Mann-Whitney test; } \\
\text { Paired t-test }\end{array}$ & $\begin{array}{l}1.299 \pm 0.3873 \\
2.472 \pm 0.7287 \\
23.23 \pm 1.761 v s\end{array}$ & $\begin{array}{c}v s \\
v s \\
29.26 \pm\end{array}$ & $\begin{array}{l}0.9214 \pm 0.3131 \\
8.419 \pm 1.111 \\
\pm 1.931\end{array}$ & & $\begin{array}{l}\text { GCamp6m vs EYFP (pre: } P=0.0451, \\
\mathrm{t}=2.027 \mathrm{df}=107 \text {; attack: } P<0.001, \mathrm{t}=4.009 \\
\mathrm{df}=107 \text {; post: } P<0.001, \quad \mathrm{U}=57 \text {; } \\
\text { GCamp6m: pre vs attack, } P<0.001 \text {, } \\
\mathrm{t}=11.64 \mathrm{df}=98\end{array}$ & $\begin{array}{l}\text { 10/99tria } \\
\text { ls }\end{array}$ \\
\hline S2N & $\begin{array}{l}\text { EYFP and GCamp6m Group, } \\
\text { Peak value in last attacks }\end{array}$ & $\begin{array}{l}\text { Mann-Whitney test; } \\
\text { Wilcoxon matched- } \\
\text { pairs signed-rank } \\
\text { test }\end{array}$ & $\begin{array}{l}1.935 \pm 0.4055 \\
2.100 \pm 0.6013 \\
20.07 \pm 2.030 v s\end{array}$ & $\begin{array}{c}v s \\
v s \\
16.21 \pm \\
\end{array}$ & $\begin{array}{r}2.026 \pm 0.7418 \\
19.53 \pm 1.657 \\
\pm 1.971 \\
\end{array}$ & $\begin{array}{l}v s \\
v s\end{array}$ & $\begin{array}{l}\text { GCamp6m vs EYFP (pre: } P<0.001 \text {, } \\
\mathrm{U}=136 \text {; attack: } P<0.001, \mathrm{U}=142 \text {; post: } P< \\
0.001, \mathrm{U}=177) ; \mathrm{GCamp6m:} \text { pre } v \text { attack, } P \\
=0.4835, \mathrm{~W}=404\end{array}$ & $\begin{array}{c}\text { 10/99tria } \\
\text { ls }\end{array}$ \\
\hline S2N & $\begin{array}{l}\text { EYFP and GCamp6m Group, } \\
\text { Peak value in single, first and } \\
\text { last attacks }\end{array}$ & Mann-Whitney test & $\begin{array}{l}\text { Peak value in } \mathrm{p} \\
\text { last attacks, } \mathrm{P} \\
\mathrm{U}=3121\end{array}$ & $\begin{aligned} 20 \text { ost- sin } \\
<0.001 \\
\end{aligned}$ & $\begin{array}{l}\text { ingle vs last attac } \\
1, \mathrm{U}=2881 ; \text { Peak }\end{array}$ & & $\begin{array}{l}0.001, \mathrm{U}=5774 \text {; Peak value in pre- first } v s \\
\text { e in post- single } v \text { s last attacks, } P<0.001,\end{array}$ & $\begin{array}{c}165 / 99 / 9 \\
9 \text { trials }\end{array}$ \\
\hline S2P & $\begin{array}{l}\text { GCamp6m Group of } \\
\text { continuous attacks, Peak value } \\
\text { in pre-attack }\end{array}$ & $\begin{array}{l}\text { Kruskal-Wallis test; } \\
\text { Mann-Whitney test }\end{array}$ & $\begin{array}{l}8.454 \pm 0.8678 \\
23.34 \pm 3.593 \\
21.01 \pm 4.794 \\
19.18 \pm 1.667 \\
\end{array}$ & $\begin{array}{c}s \\
v s \\
v s\end{array}$ & $\begin{array}{l}21.67 \pm 2.306 \\
25.22 \pm 4.103 \\
23.26 \pm 4.088\end{array}$ & $\begin{array}{l}v s \\
v s \\
v s\end{array}$ & $\begin{array}{l}1-7 \text { continuous attacks, } P<0.001 \text {, } \\
\mathrm{KW}=53.00 \text {; First } v s \text { second, } P<0.001 \text {, } \\
\mathrm{U}=930.5 \text {; Last } v s \text { second, } P=0.2623 \text {, } \\
\mathrm{U}=1875\end{array}$ & $\begin{array}{c}99 / 43 / 24 \\
/ 13 / 8 / 4 / 9 \\
9 \text { trials }\end{array}$ \\
\hline S2P & $\begin{array}{l}\text { GCamp6m Group of } \\
\text { continuous attacks, Peak value } \\
\text { in attack }\end{array}$ & Kruskal-Wallis test & $\begin{array}{l}25.00 \pm 1.567 \\
25.62 \pm 3.512 \\
22.77 \pm 3.824 \\
24.04 \pm 1.976 \\
\end{array}$ & $\begin{array}{l}v s \\
v s \\
v s\end{array}$ & $\begin{array}{l}26.60 \pm 2.651 \\
23.79 \pm 3.984 \\
28.98 \pm 4.508\end{array}$ & $\begin{array}{l}v s \\
v s \\
v s\end{array}$ & $\begin{array}{l}1-7 \text { continuous attacks, } P=0.9688 \text {, } \\
\mathrm{KW}=1.351\end{array}$ & $\begin{array}{c}99 / 43 / 24 \\
113 / 8 / 4 / 9 \\
9 \text { trials }\end{array}$ \\
\hline S2P & $\begin{array}{l}\text { GCamp6m Group of } \\
\text { continuous attacks, Peak value } \\
\text { in post-attack }\end{array}$ & $\begin{array}{l}\text { Kruskal-Wallis test; } \\
\text { Unpaired t-test }\end{array}$ & $\begin{array}{l}29.50 \pm 1.783 \\
28.64 \pm 3.686 \\
27.37 \pm 4.707 \\
19.45 \pm 1.933 \\
\end{array}$ & $\begin{array}{l}v s \\
v s \\
v s\end{array}$ & $\begin{array}{l}29.56 \pm 3.012 \\
23.39 \pm 5.809 \\
30.42 \pm 5.473\end{array}$ & $\begin{array}{l}v s \\
v s \\
v s\end{array}$ & $\begin{array}{l}1-7 \text { continuous attacks, } P=0.0189, \\
\mathrm{KW}=15.18 \text {; First } v s \text { second, } P=0.9867, \mathrm{t}= \\
0.01671 \mathrm{df}=140 \text {; Last } v s \text { second, } P=0.005, \\
\mathrm{t}=2.854 \mathrm{df}=140\end{array}$ & $\begin{array}{c}99 / 43 / 24 \\
/ 13 / 8 / 4 / 9 \\
9 \text { trials }\end{array}$ \\
\hline S3B & $\begin{array}{l}\text { Linear regression of the AUC } \\
\text { per second of GCaMP6m } \\
\text { signals and possibilities of } \\
\text { attacks prior to the attack } \\
\text { behavior }\end{array}$ & Linear regression & $\mathrm{Y}=0.001644 * \mathrm{X}$ & $X+0.0$ & 1182 & & $\mathrm{R}^{2}=0.03025 ; P=0.2832$ & 40 trials \\
\hline S3D & $\begin{array}{l}\text { Linear regression of the AUC } \\
\text { per second of GCaMP6m } \\
\text { signals and possibilities of } \\
\text { attacks prior to the attack } \\
\text { behavior }\end{array}$ & Linear regression & $\mathrm{Y}=-0.002264 *$ & $\mathrm{X}+0.0$ & 08717 & & $\mathrm{R}^{2}=0.3545 ; P<0.0001$ & 40 trials \\
\hline S3E & $\begin{array}{l}\text { The Peak } \Delta \mathrm{F} / \mathrm{F} \text { of GCaMP6m } \\
\text { in attack behaviors }\end{array}$ & Kruskal-Wallis test & $\begin{array}{l}18.36 \pm 1.058 \\
19.50 \pm 1.697 v s\end{array}$ & $\begin{array}{c}v s \\
21.80 \pm\end{array}$ & $\begin{array}{l}21.47 \pm 2.229 \\
\pm 1.663\end{array}$ & & $P=0.1270 ; \mathrm{KW}=5.704$ & $\begin{array}{c}458 / 165 / \\
99 / 99 \\
\text { trials } \\
\end{array}$ \\
\hline S3G & $\begin{array}{l}\text { Single/first (attack) decoding } \\
\text { accuracy in shuffle and } \\
\text { recoding }\end{array}$ & $\begin{array}{l}\text { Mann-Whitney test; } \\
\text { Wilcoxon matched- } \\
\text { pairs signed-rank } \\
\text { test }\end{array}$ & $\begin{array}{l}49.74 \pm 0.4551 \\
49.57 \pm 0.4643 \\
57.89 \pm 0.4574 v\end{array}$ & $\begin{array}{l}v s \\
v s \\
s 66.32\end{array}$ & $\begin{array}{r}49.95 \pm 0.4038 \\
55.80 \pm 0.4628 \\
2 \pm 0.4410\end{array}$ & $\begin{array}{l}v s \\
v s\end{array}$ & $\begin{array}{l}\text { Shuffle vs recoding: Pre, } P<0.001, \\
\mathrm{U}=385461 ; \text { Beh, } P<0.001, \mathrm{U}=340263 ; \\
\text { Post, } P<0.001, \mathrm{U}=207572 . \text { Recoding: Pre } \\
v s \text { Beh, } P=0.0019, \mathrm{~W}=40899 ; \text { Pre vs post, } \\
P<0.001, \mathrm{~W}=199251\end{array}$ & $\begin{array}{c}1000 / 100 \\
0\end{array}$ \\
\hline S3I & $\begin{array}{l}\text { Single/last (attack) decoding } \\
\text { accuracy in shuffle and } \\
\text { recoding }\end{array}$ & $\begin{array}{l}\text { Mann-Whitney test; } \\
\text { Wilcoxon matched- } \\
\text { pairs signed-rank } \\
\text { test }\end{array}$ & $\begin{array}{l}49.16 \pm 0.4791 \\
49.46 \pm 0.4599 \\
53.16 \pm 0.4350 v\end{array}$ & $\begin{array}{l}v s \\
v s \\
\text { ss } \\
55.11\end{array}$ & $\begin{array}{l}49.74 \pm 0.4235 \\
62.77 \pm 0.4398 \\
1 \pm 0.4624\end{array}$ & $\begin{array}{l}v s \\
v s\end{array}$ & $\begin{array}{l}\text { Shuffle vs recoding: Pre, } P<0.001, \\
\mathrm{U}=259307 ; \text { Beh, } P<0.001, \mathrm{U}=427698 ; \\
\text { Post, } P<0.001, \mathrm{U}=389430 . \text { Recoding: Pre } \\
v s \text { Beh, } P<0.001, \mathrm{~W}=-79639 ; \text { Pre } v s \text { post, } \\
P<0.001, \mathrm{~W}=-145607\end{array}$ & $\begin{array}{c}1000 / 100 \\
0\end{array}$ \\
\hline S3M & $\begin{array}{l}\text { Approach/predatory (attack) } \\
\text { decoding accuracy in shuffle } \\
\text { and recoding }\end{array}$ & $\begin{array}{l}\text { Mann-Whitney test; } \\
\text { Wilcoxon matched- } \\
\text { pairs signed-rank } \\
\text { test }\end{array}$ & $\begin{array}{l}49.75 \pm 0.5053 \\
48.74 \pm 0.4686 \\
56.11 \pm 0.4872 v\end{array}$ & $\begin{array}{l}v s \\
v s \\
\text { s } 53.88\end{array}$ & $\begin{array}{l}50.35 \pm 0.4804 \\
60.29 \pm 0.4891 \\
8 \pm 0.4814\end{array}$ & $\begin{array}{l}v s \\
v s\end{array}$ & $\begin{array}{l}\text { Shuffle vs recoding: Pre, } P<0.001, \\
\mathrm{U}=320836 ; \text { Beh, } P<0.001, \mathrm{U}=394073 ; \\
\text { Post, } P<0.001, \mathrm{U}=400667 . \text { Recoding: Pre } \\
\text { vs Beh, } P<0.001, \mathrm{~W}=299829 ; \text { Pre } v s \text { post, } \\
P<0.001, \mathrm{~W}=-120570\end{array}$ & $\begin{array}{c}1000 / 100 \\
0\end{array}$ \\
\hline S3O & $\begin{array}{l}\text { Approach/pup-directed } \\
\text { (attack) decoding accuracy in } \\
\text { shuffle and recoding }\end{array}$ & $\begin{array}{l}\text { Mann-Whitney test; } \\
\text { Wilcoxon matched- } \\
\text { pairs signed-rank } \\
\text { test }\end{array}$ & $\begin{array}{l}50.81 \pm 0.4755 \\
50.66 \pm 0.4858 \\
68.12 \pm 0.4780 v\end{array}$ & $\begin{array}{l}v s \\
v s \\
64.73\end{array}$ & $\begin{array}{l}49.95 \pm 0.4939 \\
72.97 \pm 0.4410 \\
3 \pm 0.5095\end{array}$ & $\begin{array}{l}v s \\
v s\end{array}$ & $\begin{array}{l}\text { Shuffle vs recoding: } \quad \text { Pre, } P<0.001, \\
\mathrm{U}=147955 ; \text { Beh, } P<0.001, \mathrm{U}=209369 ; \\
\text { Post, } P<0.001, \mathrm{U}=265718 . \text { Recoding: Pre } \\
v s \text { Beh, } P<0.001, \mathrm{~W}=-101899 ; \text { Pre } v \text { post, } \\
P<0.001, \mathrm{~W}=-154832\end{array}$ & $\begin{array}{c}1000 / 100 \\
0\end{array}$ \\
\hline $\mathbf{S 3 Q}$ & Female-male & Mann-Whitney test; & $50.29 \pm 0.4550$ & vs & $49.33 \pm 0.4550$ & vs & $\begin{array}{ll}\text { Shuffle } v s \text { recoding: } & \text { Pre, } P<0.001\end{array}$ & $1000 / 100$ \\
\hline
\end{tabular}


bioRxiv preprint doi: https://doi.org/10.1101/2020.04.22.047670; this version posted February 19, 2021. The copyright holder for this preprint (which was not certified by peer review) is the author/funder, who has granted bioRxiv a license to display the preprint in perpetuity. It is made available under aCC-BY-NC-ND 4.0 International license.

\begin{tabular}{|c|c|c|c|c|c|c|}
\hline & $\begin{array}{l}\text { male attack decoding accuracy } \\
\text { in shuffle and recoding }\end{array}$ & $\begin{array}{l}\text { Wilcoxon matched- } \\
\text { pairs signed-rank } \\
\text { test }\end{array}$ & $\begin{array}{llll}50.18 \pm 0.4510 & \text { vs } & 54.13 \pm 0.4421 \\
57.40 \pm 0.4557 & \text { vs } & 54.11 \pm 0.4261\end{array}$ & & $\begin{array}{l}\mathrm{U}=423148 ; \text { Beh, } P<0.001, \mathrm{U}=348253 ; \\
\text { Post, } P<0.001, \mathrm{U}=420140 . \text { Recoding: Pre } \\
\text { vs Beh, } P<0.001, \mathrm{~W}=66857 \text {; Pre } v s \text { post, } P \\
<0.001, \mathrm{~W}=-4625\end{array}$ & 0 \\
\hline S3S & $\begin{array}{l}\text { Approach/ approach (attack) } \\
\text { decoding accuracy in shuffle } \\
\text { and recoding }\end{array}$ & $\begin{array}{l}\text { Mann-Whitney test; } \\
\text { Wilcoxon matched- } \\
\text { pairs signed-rank } \\
\text { test }\end{array}$ & $\begin{array}{lcc}50.69 \pm 14.77 & \text { vs } & 50.46 \pm 0.4563 \\
49.32 \pm 0.4833 & v s & 56.09 \pm 0.4983 \\
67.42 \pm 0.4823 & \text { vs } 59.95 \pm 0.4991\end{array}$ & $\begin{array}{l}v s \\
v s\end{array}$ & $\begin{array}{l}\text { Shuffle } v s \text { recoding: Pre, } P<0.001, \\
\mathrm{U}=402551 ; \text { Beh, } P<0.001, \mathrm{U}=215285 ; \\
\text { Post, } P<0.001, \mathrm{U}=317394 . \text { Recoding: Pre } \\
v s \text { Beh, } P<0.001, \mathrm{~W}=210500 \text {; Pre } v s \text { post, } \\
P<0.001, \mathrm{~W}=74759\end{array}$ & $\begin{array}{c}1000 / 100 \\
0\end{array}$ \\
\hline S3U & $\begin{array}{l}\text { Pup-directed } \\
\text { approach/approach (attack) } \\
\text { decoding accuracy in shuffle } \\
\text { and recoding }\end{array}$ & $\begin{array}{l}\text { Mann-Whitney test; } \\
\text { Wilcoxon matched- } \\
\text { pairs signed-rank } \\
\text { test }\end{array}$ & $\begin{array}{lll}49.02 \pm 0.4784 & \text { vs } & 49.58 \pm 0.4345 \\
49.13 \pm 0.4954 & v s & 61.31 \pm 0.4875 \\
64.98 \pm 0.4767 & \text { vs } 71.45 \pm 0.4550\end{array}$ & $\begin{array}{l}v s \\
v s\end{array}$ & $\begin{array}{l}\text { Shuffle } v s \text { recoding: Pre, } P<0.001, \\
\mathrm{U}=288077 ; \text { Beh, } P<0.001, \mathrm{U}=228883 ; \\
\text { Post, } P<0.001, \mathrm{U}=153610 . \text { Recoding: Pre } \\
\text { vs Beh, } P<0.001, \mathrm{~W}=74342 \text {; Pre } v s \text { post, } P \\
<0.001, \mathrm{~W}=191828\end{array}$ & $\begin{array}{c}1000 / 100 \\
0\end{array}$ \\
\hline S3W & $\begin{array}{l}\text { Female-male sniff/sniff(attack) } \\
\text { decoding accuracy in shuffle } \\
\text { and recoding }\end{array}$ & $\begin{array}{l}\text { Mann-Whitney test; } \\
\text { Wilcoxon matched- } \\
\text { pairs signed-rank } \\
\text { test }\end{array}$ & $\begin{array}{lcr}49.28 \pm 0.438 & \text { vs } & 50.28 \pm 0.459 \\
49.54 \pm 0.461 & \text { vs } & 53.21 \pm 0.462 \\
69.69 \pm 0.430 \text { vs } & 59.28 \pm 0.4524\end{array}$ & $\begin{array}{l}v s \\
v s\end{array}$ & $\begin{array}{l}\text { Shuffle vs recoding: Pre, } P<0.001, \\
\mathrm{U}=426905 ; \text { Beh, } P<0.001, \mathrm{U}=295332 ; \\
\text { Post, } P<0.001, \mathrm{U}=368411 . \text { Recoding: Pre } \\
\text { vs Beh, } P<0.001, \mathrm{~W}=169026 ; \text { Pre } v s \text { post, } \\
P<0.001, \mathrm{~W}=99728\end{array}$ & $\begin{array}{c}1000 / 100 \\
0\end{array}$ \\
\hline S3Y & 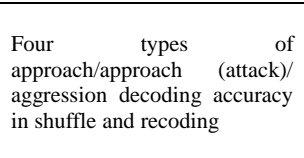 & $\begin{array}{l}\text { Wilcoxon matched- } \\
\text { pairs signed-rank } \\
\text { test; Mann-Whitney } \\
\text { test }\end{array}$ & $\begin{array}{llll}32.14 \pm 0.3121 & v s & 28.73 \pm 0.2895 & v \\
33.33 \pm 0.3439 & v s & 32.25 \pm 0.3133 & v \\
36.11 \pm 0.3128 & v s & 37.48 \pm 0.3372 & v \\
37.94 \pm 0.3342 & v s & 40.06 \pm 0.3119 & v \\
37.47 \pm 0.3275 & & & \end{array}$ & $\begin{array}{l}v s \\
v s \\
v s \\
v s\end{array}$ & $\begin{array}{l}\text { Pre vs Beh, approach, } P<0.001, \mathrm{~W}=- \\
112561 ; \text { approach (attack), } P<0.001 \text {, } \\
\text { W=122698; attack, } P<0.001, \mathrm{~W}=71717 \text {; } \\
\text { Beh, approach vs approach (attack): } P< \\
0.001, \mathrm{U}=293364 ; \text { approach } v s \text { attack: } P< \\
0.001, \mathrm{U}=389620\end{array}$ & $\begin{array}{c}1000 / 100 \\
0\end{array}$ \\
\hline S3AA & $\begin{array}{l}\text { Six types of aggression } \\
\text { decoding accuracy in shuffle } \\
\text { and recoding }\end{array}$ & $\begin{array}{l}\text { Mann-Whitney test; } \\
\text { Wilcoxon matched- } \\
\text { pairs signed-rank } \\
\text { test }\end{array}$ & $\begin{array}{l}16.89 \pm 0.2094 \text { vs } \quad 16.91 \pm 0.1726 \\
16.48 \pm 0.1975 \text { vs } \\
31.49 \pm 0.2483 \text { vs } 29.53 \pm 0.2447\end{array}$ & $\begin{array}{l}v s \\
v s\end{array}$ & $\begin{array}{l}\text { Shuffle } v s \text { recoding: Pre, } P<0.001, \\
\mathrm{U}=98544 \text {; Beh, } P<0.001, \mathrm{U}=61998 ; \text { Post, } \\
P<0.001, \mathrm{U}=95592 . \quad \text { Recoding: Pre } v s \\
\text { Beh, } P<0.001, \mathrm{~W}=63543 \text {; Pre } v \text { p post, } P< \\
0.001, \mathrm{~W}=-27648\end{array}$ & $\begin{array}{c}1000 / 100 \\
0\end{array}$ \\
\hline S4I & $\begin{array}{l}\text { The Peak } \Delta \mathrm{F} / \mathrm{F} \text { of GCaMP6m } \\
\text { in various stimuli }\end{array}$ & $\begin{array}{l}\text { Wilcoxon matched- } \\
\text { pairs signed-rank } \\
\text { test; Paired t-test }\end{array}$ & $\begin{array}{lcll}5.886 \pm 0.9575 & v s & 2.931 \pm 0.2572 & v \\
4.023 \pm 0.7258 & v s & 5.218 \pm 0.8725 & v \\
6.1560 .9221 & v s & 5.47 \pm 0.7139 & v \\
14.29 \pm 1.119 & v s & 28.86 \pm 2.026 & v \\
26.08 \pm 2.221 & & & \\
\end{array}$ & $\begin{array}{l}v s \\
v s \\
v s \\
v s\end{array}$ & $\begin{array}{l}P=0.0089, \quad \mathrm{t}=2.718 \quad \mathrm{df}=51 ; P= \\
0.1174, \mathrm{~W}=-2379 ; P=0.0028, \quad \mathrm{t}=3.371 \\
\mathrm{df}=22 ; P=0.0128, \mathrm{~W}=239 ; P=0.0044, \\
\mathrm{~W}=356 ; P<0.001, \mathrm{t}=6.689 \mathrm{df}=56 ; P< \\
0.001, \mathrm{~W}=794 ; P<0.001, \mathrm{~W}=820 ; P< \\
0.001, \mathrm{t}=9.605 \mathrm{df}=39\end{array}$ & $\begin{array}{l}52 / 260 / 2 \\
3 / 30 / 36 / \\
57 / 40 / 40 \\
/ 40 \text { trials }\end{array}$ \\
\hline S4I & $\begin{array}{l}\text { AUC per second of } \\
\text { GCaMP6m in various stimuli }\end{array}$ & $\begin{array}{l}\text { Wilcoxon matched- } \\
\text { pairs signed-rank } \\
\text { test; Paired t-test }\end{array}$ & $\begin{array}{lccc}0.02068 \pm 0.00835 & \text { vs } & 0.00561 \pm 0.0021 v \\
0.01227 \pm 0.00637 & \text { vs } & 0.01569 \pm 0.0076 & v \\
0.02665 \pm 0.0080 & \text { vs } & 0.0323 \pm 0.0060 & v \\
0.0651 \pm 0.0099 & \text { vs } & 0.1915 \pm 0.0201 & \text { v } \\
0.2002 \pm 0.01385 & & & \\
\end{array}$ & \begin{tabular}{|l|}
$v s$ \\
$v s$ \\
$v s$ \\
$v s$
\end{tabular} & $\begin{array}{l}P=0.5122, \mathrm{~W}=-146 ; P=0.0329, \mathrm{~W}=-522 ; \\
P=0.8124, \mathrm{t}=0.2402 \mathrm{df}=22 ; P=0.1057, \\
\mathrm{~W}=-753 ; P=0.0363, \mathrm{~W}=266 ; P=0.1089, \\
\mathrm{~W}=405 ; P<0.001, \mathrm{~W}=794 ; P<0.001, \\
\mathrm{~W}=820 ; P<0.001, \mathrm{t}=4.645, \mathrm{df}=39\end{array}$ & $\begin{array}{l}52 / 260 / 2 \\
3 / 20 / 36 / \\
57 / 40 / 40 \\
140 \text { trials } \\
\end{array}$ \\
\hline S40 & $\begin{array}{l}\text { The Peak } \Delta \mathrm{F} / \mathrm{F} \text { of GCaMP6m } \\
\text { in various threats }\end{array}$ & $\begin{array}{l}\text { Wilcoxon matched- } \\
\text { pairs signed-rank } \\
\text { test; Paired t-test; } \\
\text { Mann-Whitney test }\end{array}$ & $\begin{array}{llr}1.831 \pm 0.4328 & \text { vs } & 6.403 \pm 1.025 \\
3.031 \pm 0.5995 & \text { vs } & 10.49 \pm 1.193 \\
5.142 \pm 1.067 & \text { vs } & 19.34 \pm 1.814 \\
6.119 \pm 1.420 & \text { vs } & 28.77 \pm 2.060 \\
3.530 \pm 0.6563 \text { vs } 27.10 \pm 2.553\end{array}$ & $\begin{array}{l}v s \\
v s \\
v s \\
v s\end{array}$ & $\begin{array}{l}\text { Versus baseline }(P<0.001, \mathrm{~W}=931 ; P< \\
0.001, \mathrm{~W}=752 ; P<0.001, \mathrm{~W}=726 ; P< \\
0.001, \mathrm{~W}=1711 ; P \quad 0.001, \mathrm{t}=8.744, \\
\mathrm{df}=27) ; \text { female } v s \text { object: } P=0.005, \\
\mathrm{U}=681 \text {; male } v \text { s female: } P<0.001, \mathrm{U}=377 \\
\text { male CD- } 1 \text { vs male: } P=0.004, \mathrm{U}=743 ; \\
\text { male attack } v s \text { male: } P=0.0203, \mathrm{U}=364\end{array}$ & $\begin{array}{l}53 / 53 / 39 \\
139 / 39 / 3 \\
9 / 58 / 58 / \\
28 / 28 \\
\text { trials }\end{array}$ \\
\hline S40 & $\begin{array}{l}\text { AUC per second of } \\
\text { GCaMP6m in various threats }\end{array}$ & $\begin{array}{l}\text { Wilcoxon matched- } \\
\text { pairs signed-rank } \\
\text { test; Paired t-test; } \\
\text { Mann-Whitney test }\end{array}$ & $\begin{array}{l}-0.00078 \pm 0.00347 \text { vs } 0.02357 \pm 0.0069 \text { v } \\
0.00204 \pm 0.0051 \text { vs } 0.05571 \pm 0.00819 \text { v } \\
0.01166 \pm 0.0074 \text { vs } 0.0936 \pm 0.0107 \\
0.02065 \pm 0.00653 \text { vs } 0.1813 \pm 0.01490 \text { v } \\
0.00253 \pm 0.00512 \text { vs } 0.1310 \pm 0.01195\end{array}$ & & $\begin{array}{l}\text { Versus baseline }(P<0.001, \mathrm{~W}=951 ; P< \\
0.001, \mathrm{t}=7.672, \mathrm{df}=38 ; P<0.001, \mathrm{~W}=676 ; \\
P<0.001, \mathrm{~W}=1711 ; P<0.001, \quad \mathrm{t}=10.59 \\
\mathrm{df}=27) \text { female } \text { vs object: } P=0.007, \\
\mathrm{U}=694 ; \text { male } \text { s female: } P=0.0083, \\
\mathrm{U}=498 ; \text { male } \mathrm{CD}-1 \text { vs male: } P=0.0001, \\
\mathrm{U}=613 ; \text { male attack } \text { vs male: } P=0.0337 \\
\mathrm{U}=379\end{array}$ & $\begin{array}{l}53 / 53 / 39 \\
139 / 39 / 3 \\
9 / 58 / 58 / \\
28 / 28 \\
\text { trials }\end{array}$ \\
\hline $\mathrm{S5H}$ & Thy1 vs CaMKII $\alpha$ vs GAD67 & Kruskal-Wallis test & $\begin{array}{cll}87.39 \pm 3.924 & v s & 74.63 \pm 6.663 \\
3.668 \pm 1.687 & & \\
\end{array}$ & & $=11.65$ & $\begin{array}{l}5 / 5 / 6 \\
\text { mice }\end{array}$ \\
\hline S5R & $\begin{array}{l}\text { Pre-CNO vs CNO in mCherry } \\
\text { Group, } \quad \text { Latency(L), } \\
\text { Duration(D), Events(E) }\end{array}$ & Paired t-test & $\begin{array}{lll}\text { L: } 618.2 \pm 116.3 \text { vs } 547.1 \pm 140.4 ; & \mathrm{D} \\
1.727 \pm 0.7234 \text { vs } 1.537 \pm 0.6903 ; & \mathrm{E} \\
5.429 \pm 2.543 \text { vs } 3.857 \pm 1.752 . & \\
\end{array}$ & & $\begin{array}{l}\text { L: } P=0.7146 ; \mathrm{t}=0.3835 \mathrm{df}=6 ; \mathrm{D}: P= \\
0.829 ; \mathrm{t}=0.2256 \mathrm{df}=6 ; \mathrm{E}: P=0.5908 \mathrm{t}= \\
0.5678 \mathrm{df}=6 ;\end{array}$ & $7 / 7$ mice \\
\hline S5R & $\begin{array}{l}\text { Saline } v s \text { CNO in mCherry } \\
\text { Group, } \quad \text { Latency(L), } \\
\text { Duration(D), Events(E) }\end{array}$ & $\begin{array}{l}\text { Wilcoxon matched- } \\
\text { pairs signed-rank } \\
\text { test }\end{array}$ & $\begin{array}{lll}\mathrm{L}: & 672.9 \pm 146.6 \text { vs } 547.1 \pm 140.4 ; & \mathrm{D} \\
0.9843 \pm 0.9497 \text { vs } 1.537 \pm 0.6903 ; & \mathrm{E} \\
2 \pm 1.839 \text { vs } 3.857 \pm 1.752 . & \end{array}$ & & $\begin{array}{l}\mathrm{L}: P=0.6250 ; \mathrm{W}=-5 ; \mathrm{D}: P=0.6250 \\
\mathrm{~W}=5 ; \mathrm{E}: P=0.6250 ; \mathrm{W}=5 ;\end{array}$ & $7 / 7$ mice \\
\hline S5R & $\begin{array}{l}\text { Pre-CNO vs CNO in HM3D } \\
\text { Group, } \quad \text { Latency(L), } \\
\text { Duration(D), Events(E) }\end{array}$ & $\begin{array}{l}\text { Wilcoxon matched- } \\
\text { pairs signed-rank } \\
\text { test }\end{array}$ & $\begin{array}{llll}\mathrm{L}: & 827.7 \pm 63.13 \text { vs } & 45.45 \pm 13.96 ; & \mathrm{D} \\
0.076 \pm 0.05538 \text { vs } 11.09 \pm 3.925 ; & \mathrm{E} \\
0.2 \pm 0.1333 \text { vs } 14.2 \pm 1.843 & \end{array}$ & & $\begin{array}{l}\mathrm{L}: P=0.0020 ; \mathrm{W}=-55 ; \mathrm{D}: P=0.0020 \text {; } \\
\mathrm{W}=55 ; \mathrm{E}: P=0.0020 ; \mathrm{W}=55 ;\end{array}$ & $\begin{array}{l}10 / 10 \\
\text { mice }\end{array}$ \\
\hline S5R & $\begin{array}{l}\text { Saline } v s \text { CNO in HM3D } \\
\text { Group, } \\
\text { Duration(D), Events(E) } \\
\text { Latency(L), }\end{array}$ & $\begin{array}{l}\text { Wilcoxon matched- } \\
\text { pairs signed-rank } \\
\text { test }\end{array}$ & 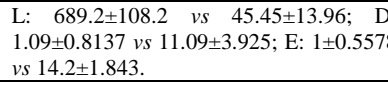 & & $\begin{array}{l}\mathrm{L}: P=0.0020 ; \mathrm{W}=-55 ; \mathrm{D}: P=0.0020 \\
\mathrm{~W}=45 ; \mathrm{E}: P=0.0020 ; \mathrm{W}=55 ;\end{array}$ & $\begin{array}{l}10 / 10 \\
\text { mice }\end{array}$ \\
\hline S6F & $\begin{array}{l}5 \mathrm{~Hz} \text { vs } 10 \mathrm{~Hz} \text { vs } 20 \mathrm{~Hz} \text { vs } 40 \\
\mathrm{~Hz} \text { in } \mathrm{ChR} 2 \mathrm{Group}\end{array}$ & Friedman test & $\begin{array}{l}0 \pm 0 \text { vs } 6.667 \pm 3.333 \text { vs } 34.44 \pm 11.68 \text { v } \\
90 \pm 6.667\end{array}$ & & $P<0.001 ; \mathrm{FM}=23.80$ & 9 mice \\
\hline S6H & $\begin{array}{l}\text { Pre } v s \text { Laser } v s \text { Post in ChR2 } \\
\text { Group, Relative pupil size }\end{array}$ & test & $1 \pm 0$ vs $1.262 \pm 0.0666$ vs $1.163 \pm 0.05992$ & & 6.22 & mice \\
\hline S6I & $\begin{array}{l}\text { Pre vs Laser vs Post in ChR2 } \\
\text { Group, Time in open arm }\end{array}$ & Friedman test & $15.41 \pm 6.22$ vs $16.06 \pm 6.82$ vs $14.07 \pm 5.382$ & & $P=0.7407 ; \mathrm{FM}=0.7429$ & 9 mice \\
\hline S6J & $\begin{array}{l}\text { Pre vs Laser vs Post in ChR2 } \\
\text { Group, Time in center }\end{array}$ & $\begin{array}{l}\text { Repeated one-way } \\
\text { ANOVA }\end{array}$ & $\begin{array}{l}10.73 \pm 1.742 \\
13.61 \pm 4.572 \\
\end{array}$ & & $P=0.7599 ; \mathrm{F}(1.608,12.87)=0.2183$ & 9 mice \\
\hline S6L & Latency to the nest & Friedman test & $\begin{array}{ll}v s & 13.65 \pm 0.658 \\
\end{array}$ & & $P=0.0721 ; \mathrm{FM}=5.333$ & 6 mice \\
\hline S6N & $\begin{array}{l}\text { averaged velocity in each } \\
\text { photostimulation period }\end{array}$ & $\begin{array}{l}\text { Repeated one-way } \\
\text { ANOVA }\end{array}$ & $\begin{array}{llll}0.034 \pm 0.004 & v s & 0.02467 \pm 0.004 & v \\
0.028 \pm 0.003 & & & \\
\end{array}$ & $v s$ & $P=0.3379 ; \mathrm{F}(1.379,6.896)=1.181$ & 6 mice \\
\hline S60 & $\begin{array}{l}\text { velocity in the pre, during, } \\
\text { post-laser period }\end{array}$ & $\begin{array}{l}\text { Repeated one-way } \\
\text { ANOVA }\end{array}$ & $\begin{array}{lll}0.03532 \pm 0.0035 & \text { vs } & 0.02898 \pm 0.0015 \\
0.026 \pm 0.003 & & \\
\end{array}$ & & $P=0.0875 ; \mathrm{F}(1.557,7.783)=3.539$ & ce \\
\hline S6T & Pre $v s$ Laser $v s$ Post in ChR2 & Friedman test & P: $0 \pm 0$ vs $65.33 \pm 4.802$ vs $0 \pm 0 ;$ L: $15 \pm 0$ v & & P: $P<0.001 ; \mathrm{FM}=29.39 ;$ L: $P<0.001$ & 15 mice \\
\hline
\end{tabular}


bioRxiv preprint doi: https://doi.org/10.1101/2020.04.22.047670; this version posted February 19, 2021. The copyright holder for this preprint (which was not certified by peer review) is the author/funder, who has granted bioRxiv a license to display the preprint in perpetuity. It is made available under aCC-BY-NC-ND 4.0 International license.

\begin{tabular}{|c|c|c|c|c|c|}
\hline & $\begin{array}{lr}\begin{array}{l}\text { Group, } \\
\text { showing }\end{array} & \text { agsibility of trials } \\
\text { Latency(L), } & \text { Duration(P), } \\
\text { Events(E) } & \\
\end{array}$ & & $\begin{array}{llrlll}4.179 \pm 2.351 \quad \text { vs } & 15 \pm 0 ; & \mathrm{D}: & 0 \pm 0 & v s \\
3.755 \pm 0.7100 \quad \text { vs } & 0 \pm 0 ; & \mathrm{E}: & 0 \pm 0 & v s \\
2.670 \pm 0.3224 \text { vs } 0 \pm 0 & & & & \end{array}$ & $\begin{array}{l}\mathrm{FM}=29.39 ; \mathrm{D}: \mathrm{P}<0.001 ; \mathrm{FM}=29.39 ; \mathrm{E}: \mathrm{P}< \\
0.001 ; \mathrm{FM}=29.39 .\end{array}$ & \\
\hline S6T & $\begin{array}{l}\text { Laser in mCherry and ChR2 } \\
\text { Group, Possibility of trials } \\
\text { showing } \quad \text { aggression(P), } \\
\text { Latency(L), Duration(D), } \\
\text { Events(E) }\end{array}$ & $\begin{array}{l}\text { Unpaired t-test; } \\
\text { Wilcoxon matched- } \\
\text { pairs signed-rank } \\
\text { test }\end{array}$ & $\begin{array}{l}\mathrm{P}: 0 \pm 0 \text { vs } 65.33 \pm 4.802 ; \quad \mathrm{L}: \quad 15 \pm 0 \text { vs } \\
4.179 \pm 2.351 ; \mathrm{D}: 0 \pm 0 \text { vs } 3.755 \pm 0.7100 \text {; } \mathrm{E}: \\
0 \pm 0 \text { vs } 2.670 \pm 0.3224\end{array}$ & $\begin{array}{l}\mathrm{P}: \quad P<0.001 ; \mathrm{t}=8.473, \mathrm{df}=19 ; \mathrm{L}: P< \\
0.001 ; \mathrm{t}=11.10, \mathrm{df}=19 ; \mathrm{D}: P=0.0313 ; \\
\mathrm{W}=21.00 ; \mathrm{E}: P<0.001 ; \mathrm{t}=5.158, \mathrm{df}=19 .\end{array}$ & $\begin{array}{l}15 / 6 \\
\text { mice }\end{array}$ \\
\hline S7F & $\begin{array}{l}\text { Amplitudes of currents in } \\
\text { Picrotoxin and CNQX groups }\end{array}$ & Paired $t$ test & 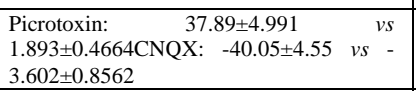 & $\begin{array}{l}\text { Picrotoxin: } \quad P=0.0043 ; \quad \mathrm{t}=7.877 \\
\mathrm{df}=3 ; \mathrm{CNQX}: P=0.0006 ; \mathrm{t}=9.732, \mathrm{df}=4 ;\end{array}$ & $\begin{array}{c}4 / 5 \\
\text { neurons }\end{array}$ \\
\hline S7J & $\begin{array}{l}\text { Pre } v s \text { Laser } v s \text { Post in ChR2 } \\
\text { Group, Possibility of trials } \\
\text { showing } \quad \text { aggression(P), } \\
\text { Latency(L), Duration(D), } \\
\text { Events(E) }\end{array}$ & Friedman test & $\begin{array}{l}\text { P: } 0 \pm 0 \text { vs } 100 \pm 0 \text { vs } 9.636 \pm 4.279 \text {; } L: 15 \pm 0 \\
\text { vs } 1.823 \pm 0.5003 \text { vs } 13.6 \pm 0.6212 \text {; } D \text { : } 0 \pm 0 \\
\text { vs } 1.624 \pm 0.2915 \text { vs } 0.02831 \pm 0.01284 \text {; E: } \\
0 \pm 0 \text { vs } 4.925 \pm 0.7838 \text { vs } 0.1164 \pm 0.05716 \text {; }\end{array}$ & $\begin{array}{l}\text { P: } P=0.0031 ; \mathrm{FM}=9.333 ; \mathrm{L}: P=0.0031 ; \\
\text { FM=9.333; } \mathrm{D}: P=0.0031 ; \mathrm{FM}=9.333 ; \mathrm{E}: P \\
=0.0031 ; \mathrm{FM}=9.333 ;\end{array}$ & 5 mice \\
\hline S7M & $\begin{array}{l}\text { Pre } v s \text { Laser } v s \text { Post in ChR2 } \\
\text { Group, Possibility of trials } \\
\text { showing agression(P), } \\
\text { Latency(L), Duration(D), } \\
\text { Events(E) }\end{array}$ & Friedman test & 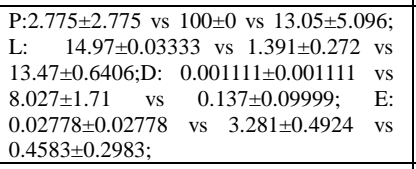 & $\begin{array}{l}\text { P: } P=0.0093 ; \mathrm{FM}=7.600 ; \mathrm{L}: P=0.0093 ; \\
\mathrm{FM}=7.600 ; \mathrm{D}: P=0.0093 ; \mathrm{FM}=7.600 ; \mathrm{E}: P \\
=0.0093 ; \mathrm{FM}=7.600 ;\end{array}$ & 4 mice \\
\hline S8C & $\begin{array}{l}\text { Pre } v s \text { Laser } v s \text { Post in ChR2 } \\
\text { Group, Possibility of trials } \\
\text { showing agression(P), } \\
\text { Latency(L), Duration(D), } \\
\text { Events(E) }\end{array}$ & $\begin{array}{l}\text { Repeated one-way } \\
\text { ANOVA }\end{array}$ & 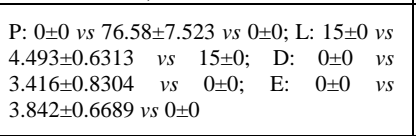 & $\begin{array}{l}\text { P: } P<0.001 \mathrm{~F}(1.000,5.000)=103.6 ; \text { L: } P \\
\text { < } P .001 \mathrm{~F}(1.000,5.000)=277.0 \text {; D: } P= \\
0.0092 \mathrm{~F}(1.000,5.000)=16.92 ; \text { E: } P= \\
0.0022 \mathrm{~F}(1.000,5.000)=32.99\end{array}$ & 6 mice \\
\hline S8D & $\begin{array}{l}\text { Pre } v s \text { Laser } v s \text { Post in ChR2 } \\
\text { Group, Possibility of trials } \\
\text { showing } \quad \text { aggression(P), } \\
\text { Latency(L), Duration(D), } \\
\text { Events(E) }\end{array}$ & $\begin{array}{l}\text { Repeated one-way } \\
\text { ANOVA }\end{array}$ & $\begin{array}{l}\text { P: } 0 \pm 0 \text { vs } 73.27 \pm 5.153 \text { vs } 0 \pm 0 ; \mathrm{L}: 15 \pm 0 \\
\text { vs } 2.490 \pm 0.4068 \text { vs } 15 \pm 0 ; \quad \mathrm{D}: 0 \pm 0 \text { vs } \\
1.717 \pm 0.3525 \text { vs } 0 \pm 0 ; \quad \mathrm{E}: 0 \pm 0 \quad \text { vs } \\
4.498 \pm 0.9287 \text { vs } 0 \pm 0\end{array}$ & $\begin{array}{l}\text { P: } P<0.001 \mathrm{~F}(1.000,5.000)=202.2 ; \text { L: } P \\
<0.001 \mathrm{~F}(1.000,5.000)=945.9 ; \text { D: } P= \\
0.0046 \mathrm{~F}(1.000,5.000)=23.71 ; \text { E: } P= \\
0.0047 \mathrm{~F}(1.000,5.000)=23.46\end{array}$ & 6 mice \\
\hline S8E & $\begin{array}{l}\text { Pre } v s \text { Laser } v s \text { Post in ChR2 } \\
\text { Group, Possibility of trials } \\
\text { showing } \quad \text { aggression(P), } \\
\text { Latency(L), Duration(D), } \\
\text { Events(E) }\end{array}$ & $\begin{array}{l}\text { Repeated one-way } \\
\text { ANOVA }\end{array}$ & $\begin{array}{l}\text { P: } 0 \pm 0 \text { vs } 66.67 \pm 37.71 \text { vs } 0 \pm 0 ; \mathrm{L}: 15 \pm 0 \\
\text { vs } 2.446 \pm 0.7965 \text { vs } 15 \pm 0 ; \quad \mathrm{D}: 0 \pm 0 \text { vs } \\
2.018 \pm 0.3606 \text { vs } 0 \pm 0 ; \quad \mathrm{E}: 0 \pm 0 \quad \text { vs } \\
5.263 \pm 1.002 \text { vs } 0 \pm 0\end{array}$ & $\begin{array}{l}\text { P: } P=0.0168 \mathrm{~F}(1.000,4.000)=15.63 ; \mathrm{L}: \\
P<0.001 \mathrm{~F}(1.000,4.000)=248.4 ; \mathrm{D}: P= \\
0.0050 \mathrm{~F}(1.000,4.000)=31.31 ; \text { E: } P= \\
0.0063 \mathrm{~F}(1.000,4.000)=27.59\end{array}$ & 5 mice \\
\hline S8H & $\begin{array}{l}\text { Pre-CNO vs CNO in HM3D } \\
\text { Group, } \quad \text { Latency(L), } \\
\text { Duration(D), Events(E) }\end{array}$ & $\begin{array}{l}\text { Wilcoxon matched- } \\
\text { pairs signed-rank } \\
\text { test and Paired t-test }\end{array}$ & $\begin{array}{l}\text { L: } 900 \pm 0 \text { vs } 174.0 \pm 124.9 ; \mathrm{D}: 0 \pm 0 \text { vs } \\
38.17 \pm 5.125 ; \mathrm{E}: 0 \pm 0 \text { vs } 28.33 \pm 4.153 ;\end{array}$ & $\begin{array}{l}\mathrm{L}: P=0.0313 \mathrm{~W}=-21 ; \mathrm{D}: P<0.001 \\
\mathrm{t}=7.447, \mathrm{df}=5 ; \mathrm{E}: P=0.001 \mathrm{t}=6.823, \mathrm{df}=5\end{array}$ & $6 / 6$ mice \\
\hline S8I & $\begin{array}{l}\text { Pre- CNO vs CNO in HM3D } \\
\text { Group, } \quad \text { Latency(L), } \\
\text { Duration(D), Events(E) }\end{array}$ & Paired t-test & $\begin{array}{l}\text { L: } 900 \pm 0 \text { vs } 204.4 \pm 62.88 ; \text { D: } 0 \pm 0 \text { vs } \\
7.403 \pm 1.901 \text {; E: } 0 \pm 0 \text { vs } 12.25 \pm 3.564 ;\end{array}$ & $\begin{array}{l}\mathrm{L}: P<0.001 \mathrm{t}=11.06 \mathrm{df}=4 ; \mathrm{D}: P=0.0176 \\
\mathrm{t}=3.895 \mathrm{df}=4 ; \mathrm{E}: P=0.0264 \mathrm{t}=3.437, \mathrm{df}=4\end{array}$ & $5 / 5$ mice \\
\hline S8J & $\begin{array}{l}\text { Pre- CNO vs CNO in HM3D } \\
\text { Group, } \quad \text { Latency(L), } \\
\text { Duration(D), Events(E) }\end{array}$ & $\begin{array}{l}\text { Wilcoxon matched- } \\
\text { pairs signed-rank } \\
\text { test and Paired t-test }\end{array}$ & $\begin{array}{l}\text { L: } 900 \pm 0 \text { vs } 171.4 \pm 108.5 ; \mathrm{D}: 0 \pm 0 \text { vs } \\
8.995 \pm 2.944 \text {; E: } 0 \pm 0 \text { vs } 10.28 \pm 2.092 ;\end{array}$ & $\begin{array}{l}\mathrm{L}: P=0.0625 \mathrm{~W}=-15 ; \mathrm{D}: P=0.0378 \\
\mathrm{t}=3.056, \mathrm{df}=4 ; \mathrm{E}: P=0.0625 \mathrm{~W}=15 ;\end{array}$ & $5 / 5$ mice \\
\hline S10F & $\begin{array}{l}\text { Pre } v s \text { Laser } v s \text { Post in ChR2 } \\
\text { Group, Possibility of trials } \\
\text { showing } \quad \text { aggression(P), } \\
\text { Latency(L), Duration(D), } \\
\text { Events(E) }\end{array}$ & $\begin{array}{lr}\text { Friedman } & \text { test; } \\
\text { Repeated } & \text { one-way } \\
\text { ANOVA } & \end{array}$ & 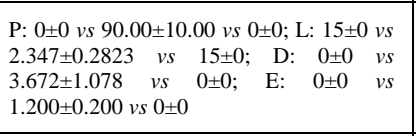 & $\begin{array}{l}\text { P: } P=0.123 ; \mathrm{FM}=10 ; \mathrm{L}: P<0.001 ; \mathrm{F} \\
(1.000,4.000)=2009 ; \mathrm{D}: P=0.0271 ; \mathrm{F} \\
(1.000,4.000)=11.61 ; \mathrm{E}: P=0.123 ; \\
\mathrm{FM}=10 .\end{array}$ & 5 mice \\
\hline S10F & $\begin{array}{l}\text { Laser in mCherry and ChR2 } \\
\text { Group, Possibility of trials } \\
\text { showing agression(P), } \\
\text { Latency(L), Duration(D), } \\
\text { Events(E) }\end{array}$ & $\begin{array}{l}\text { Mann-Whitney test; } \\
\text { Unpaired t-test }\end{array}$ & $\begin{array}{l}\mathrm{P}: \quad 0 \pm 0 \text { vs } \quad 90.00 \pm 10.00 ; \quad \mathrm{L}: 15 \pm 0 \text { vs } \\
2.347 \pm 0.2823 ; \mathrm{D}: 0 \pm 0 \text { vs } 3.672 \pm 1.078 ; \mathrm{E}: \\
0 \pm 0 \text { vs } 1.200 \pm 0.200\end{array}$ & $\begin{array}{l}\text { P: } P=0.0022 ; \mathrm{U}=0 ; \mathrm{L}: P<0.001 ; \mathrm{t}=49.65, \\
\mathrm{df}=9 ; \mathrm{D}: P=0.0044 ; \mathrm{t}=3.774, \mathrm{df}=9 ; \mathrm{E}: P= \\
0.0022 ; \mathrm{U}=0 .\end{array}$ & $6 / 5$ mice \\
\hline S10H & $\begin{array}{l}\text { Pre } v s \text { Laser } v s \text { Post in ChR2 } \\
\text { Group, Possibility of trials } \\
\text { showing aggression }\end{array}$ & $\begin{array}{l}\text { Repeated one-way } \\
\text { ANOVA } \quad \text { or } \\
\text { Friedman test }\end{array}$ & $\begin{array}{l}\text { Values of the } 1^{\text {st }}-12^{\text {nd }} \text { column: } 90 \pm 10 \text { vs } 8 \\
44 \pm 11.66 \text { vs } 92 \pm 8 \text { vs } 77.33 \pm 9.333 \text { vs } 80 \\
60.67 \pm 16.94 \text { vs } 88.75 \pm 4.146\end{array}$ & $\begin{array}{l}.33 \pm 4.167 \text { vs } 76.39 \pm 6.056 \text { vs } 80 \pm 12.65 \text { vs } \\
12.65 \text { vs } 61.91 \pm 12.28 \text { vs } 76.00 \pm 14.70 \text { vs } \\
\end{array}$ & $\begin{array}{c}5 / 3 / 3 / 5 / 5 \\
15 / 5 / 5 / 6 / \\
5 / 5 / 4 \\
\text { mice } \\
\end{array}$ \\
\hline S10I & $\begin{array}{l}\text { Pre vs Laser vs Post in ChR2 } \\
\text { Group, Latency to attack onset }\end{array}$ & $\begin{array}{l}\text { Repeated one-way } \\
\text { ANOVA } \quad \text { or } \\
\text { Friedman test }\end{array}$ & $\begin{array}{l}\text { Values of the } 1^{\text {st }}-12^{\text {nd }} \text { column: } 2.347 \pm 0.2 \\
2.256 \pm 10.5129 \text { vs } 4.849 \pm 1.699 \text { vs } 2.566 \pm 0 \\
8.169 \pm 1.244 \text { vs } 2.917 \pm 0.2879 \text { vs } 3.564 \pm 0.705\end{array}$ & $\begin{array}{l}3 \text { vs } 5.423 \pm 0.8551 \text { vs } 4.632 \pm 1.041 \text { vs } \\
01 \text { vs } 1.801 \pm 0.3906 \text { vs } 3.011 \pm 0.5467 \text { vs } \\
\text { s } 4.008 \pm 1.028\end{array}$ & $\begin{array}{l}5 / 3 / 3 / 5 / 5 \\
/ 5 / 5 / 5 / 6 / \\
5 / 5 / 4 \\
\text { mice }\end{array}$ \\
\hline S10J & $\begin{array}{l}\text { Pre } v s \text { Laser } v s \text { Post in ChR2 } \\
\text { Group, Attack duration }\end{array}$ & $\begin{array}{l}\text { Repeated one-way } \\
\text { ANOVA } \quad \text { or } \\
\text { Friedman test }\end{array}$ & $\begin{array}{l}\text { Values of the } 1^{\text {st }}-12^{\text {nd }} \text { column: } 3.672 \pm 1 \\
4.038 \pm 0.9196 \text { vs } 2.524 \pm 0.7988 \text { vs } 5.086 \pm 1.0 \\
3.403 \pm 2.160 \text { vs } 1.759 \pm 0.6263 \text { vs } 4.676 \pm 1.08\end{array}$ & $\begin{array}{l}78 \text { vs } 5.806 \pm 1.689 \text { vs } 5.511 \pm 2.350 \text { vs } \\
2 \text { vs } 3.233 \pm 1.815 \text { vs } 3.281 \pm 1.085 \text { vs NT } v s\end{array}$ & $\begin{array}{c}5 / 3 / 3 / 5 / 5 \\
15 / 5 / 5 / 6 / 6 \\
5 / 5 / 4 \\
\text { mice }\end{array}$ \\
\hline S10K & $\begin{array}{l}\text { Pre } v s \text { Laser } v s \text { Post in ChR2 } \\
\text { Group, Attack events }\end{array}$ & $\begin{array}{l}\text { Repeated one-way } \\
\text { ANOVA } \quad \text { or } \\
\text { Friedman test }\end{array}$ & $\begin{array}{l}\text { Values of the } 1^{\text {st }}-12^{\text {nd }} \text { column: } 1.200 \pm 0.2 \\
1.240 \pm 0.1939 \text { vs } 1.000 \pm 0.00 \text { vs } 1.478 \pm 0.265 \\
1.400 \pm 0.1716 \text { vs } 1.520 \pm 0.2871 \text { vs } 1.725 \pm 0.0\end{array}$ & $\begin{array}{l}00 \text { vs } 1.292 \pm 0.1816 \text { vs } 1.278 \pm 0.3100 \text { vs } \\
\text { vs } 1.333 \pm 0.1430 \text { vs } 1.197 \pm 0.05753 \text { vs NT vs } \\
35\end{array}$ & $\begin{array}{c}5 / 5 / 5 / 5 / 5 \\
/ 5 / 5 / 5 / 6 / \\
5 / 5 / 4 \\
\text { mice }\end{array}$ \\
\hline S10P & $\begin{array}{l}\text { Pre } v s \text { Laser } v s \text { Post in ChR2 } \\
\text { Group, Possibility of trials } \\
\text { showing } \quad \text { aggression(P), } \\
\text { Latency(L), Duration(D), } \\
\text { Events(E) }\end{array}$ & Friedman test & 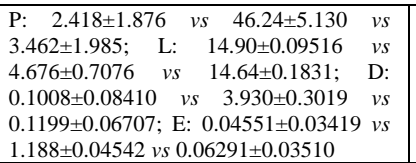 & $\begin{array}{l}\text { P: } P=0.0002 ; \mathrm{FM}=15.08 ; \mathrm{L}: P=0.0001 ; \\
\text { FM=14.89; }: P=0.0005 ; \mathrm{FM}=14.30 ; \mathrm{E}: P \\
=0.123 ; \mathrm{FM}=10 .\end{array}$ & 8 mice \\
\hline S10P & $\begin{array}{l}\text { Laser in mCherry and ChR2 } \\
\begin{array}{l}\text { Group, Possibility of trials } \\
\text { showing agression(P), } \\
\text { Latency(L), Duration(D), } \\
\text { Events(E) }\end{array} \\
\end{array}$ & Unpaired t-test & 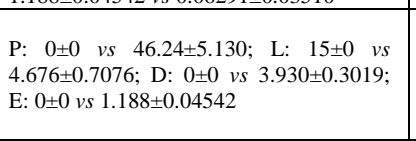 & $\begin{array}{l}\text { P: } P<0.001 ; \mathrm{t}=7.726, \mathrm{df}=12 ; \mathrm{L}: P<0.001 \\
\mathrm{t}=12.50, \quad \mathrm{df}=12 ; \mathrm{D}: P<0.001 ; \mathrm{t}=11.16, \\
\mathrm{df}=12 ; \mathrm{E}: P<0.001 ; \mathrm{t}=22.41, \mathrm{df}=12\end{array}$ & $6 / 8$ mice \\
\hline S10Q & Pre $v s$ Laser $v s$ Post in ChR2 & Repeated one-way & P: $0 \pm 0$ vs $57.64 \pm 4.861$ vs $0 \pm 0 ; \mathrm{L}: 15 \pm 0$ vs & P: $P=0.0070 ; \mathrm{F}(1.000,2.000)=140.6 ; \mathrm{L}:$ & 3 mice \\
\hline
\end{tabular}


bioRxiv preprint doi: https://doi.org/10.1101/2020.04.22.047670; this version posted February 19, 2021. The copyright holder for this preprint (which was not certified by peer review) is the author/funder, who has granted bioRxiv a license to display the preprint in perpetuity. It is made available under aCC-BY-NC-ND 4.0 International license.

\begin{tabular}{|c|c|c|c|c|c|}
\hline & $\begin{array}{lr}\text { Group, } & \text { Possibility of trials } \\
\text { showing } & \text { aggression(P), } \\
\text { Latency(L), } & \text { Duration(D), } \\
\text { Events(E) } & \\
\end{array}$ & ANOVA & $\begin{array}{lccccc}3.944 \pm 0.8333 & \text { vs } & 15 \pm 0 ; & \mathrm{D}: & 0 \pm 0 & \text { vs } \\
6.861 \pm 2.613 & \text { vs } & 0 \pm 0 ; & \mathrm{E}: & 0 \pm 0 & \text { vs } \\
1.494 \pm 0.2042 \text { vs } 0 \pm 0 & & & & \end{array}$ & $\begin{array}{l}P=0.0056 ; \mathrm{F}(1.000,2.000)=176.0 ; \mathrm{D}: P \\
=0.0451 ; \mathrm{F}(1.000,2.000)=20.68 ; \mathrm{E}: P= \\
0.0182 ; \mathrm{F}(1.000,2.000)=53.56\end{array}$ & \\
\hline S12D & $\begin{array}{l}\text { Possibility of inter-male } \\
\text { aggression before ASD and } \\
\text { after ASD during } 7 \text { intensities } \\
\text { of laser stimulation }\end{array}$ & $\begin{array}{l}\text { Non-Linear } \\
\text { regression: } \\
\text { Sigmoidal fit, 4PL } \\
\text { (laser power) }\end{array}$ & $\begin{array}{l}\text { HillSlope } \quad(\text { before } \quad \text { ASD) }=1.517 \\
\text { HillSlope }(\text { after ASD) }=3.332 ;\end{array}$ & $\begin{array}{l}\mathrm{R}^{2}(\text { before ASD })=0.7282 ; \mathrm{R}^{2}(\text { after ASD })= \\
0.5967\end{array}$ & $\begin{array}{l}120 / 117 \\
\text { trials, } 3 \\
\text { mice }\end{array}$ \\
\hline S12E & $\begin{array}{l}\text { Latency to attack onset of } \\
\text { inter-male aggression before } \\
\text { ASD and after ASD during } 7 \\
\text { intensities of laser stimulation }\end{array}$ & $\begin{array}{l}\text { Non-Linear } \\
\text { regression: } \\
\text { Sigmoidal fit, } 4 \mathrm{PL} \\
\text { (laser power) } \\
\end{array}$ & $\begin{array}{l}0,0.33,0.54,0.75,1.51,2.72,4.28 \mathrm{~mW} \\
\text { are used in inter-male aggression; } \\
\text { HillSlope (before ASD) = }-1.772 ; \\
\text { HillSlope (after ASD) }=-1.775 ;\end{array}$ & $\begin{array}{l}\left.\text { Goodness of Fit: } \mathrm{R}^{2} \text { (before ASD }\right)=0.6796 \\
\mathrm{R}^{2}(\text { after ASD })=0.5157\end{array}$ & $\begin{array}{c}120 / 117 \\
\text { trials, } 3 \\
\text { mice }\end{array}$ \\
\hline S12F & $\begin{array}{l}\text { Duration of inter-male } \\
\text { aggression before ASD and } \\
\text { after ASD during } 7 \text { intensities } \\
\text { of laser stimulation }\end{array}$ & $\begin{array}{l}\text { Non-Linear } \\
\text { regression: } \\
\text { Sigmoidal fit, 4PL } \\
\text { (laser power) }\end{array}$ & $\begin{array}{l}\text { HillSlope (before ASD) }=3.706 \text {; } \\
\text { HillSlope (after ASD) }=3.073 ;\end{array}$ & $\begin{array}{l}\mathrm{R}^{2}(\text { before ASD })=0.6155 ; \mathrm{R}^{2}(\text { after ASD })= \\
0.2558\end{array}$ & $\begin{array}{c}120 / 117 \\
\text { trials, } 3 \\
\text { mice }\end{array}$ \\
\hline S12G & $\begin{array}{lll}\text { Events } & \text { of } & \text { inter-male } \\
\text { aggression before } & \text { ASD and } \\
\text { after ASD during } 7 \text { intensities } \\
\text { of laser stimulation }\end{array}$ & $\begin{array}{l}\text { Non-Linear } \\
\text { regression: } \\
\text { Sigmoidal fit, 4PL } \\
\text { (laser power) } \\
\end{array}$ & $\begin{array}{l}\text { HillSlope }(\text { before } \text { ASD) }=2.201 ; \\
\text { HillSlope (after ASD) }=3.593 ;\end{array}$ & $\begin{array}{l}\mathrm{R}^{2}(\text { before } \mathrm{ASD})=0.6645 ; \mathrm{R}^{2}(\text { after ASD })= \\
0.3439 ;\end{array}$ & $\begin{array}{c}120 / 117 \\
\text { trials, } 3 \\
\text { mice }\end{array}$ \\
\hline S12H & $\begin{array}{l}\text { Possibility of } \text { inter-male } \\
\text { aggression before ASD and } \\
\text { after ASD during } 1.51 \mathrm{~mW} \\
\text { laser stimulation } \\
\end{array}$ & $\begin{array}{l}\text { Wilcoxon matched- } \\
\text { pairs signed-rank } \\
\text { test }\end{array}$ & 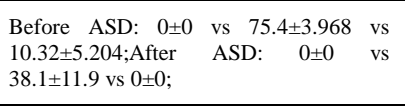 & $\begin{array}{l}\text { Before ASD vs After ASD: } P=0.2500 ; \mathrm{W}= \\
-6 ;\end{array}$ & 3 mice \\
\hline S12I & $\begin{array}{l}\text { Latency to attack onset of } \\
\text { inter-male aggression before } \\
\text { ASD and after ASD during } \\
1.51 \mathrm{~mW} \text { laser stimulation } \\
\end{array}$ & Paired t-test & $\begin{array}{l}\text { Before ASD: } 15 \pm 0 \text { vs } 5.531 \pm 1.136 \text { vs } \\
13.86 \pm 0.7276 ; \text { After ASD: } 15 \pm 0 \text { vs } \\
10.41 \pm 1.413 \text { vs } 15 \pm 0 \text {; }\end{array}$ & $\begin{array}{l}\text { Before ASD vs After ASD: } * P=0.0306 ; \mathrm{t}= \\
5.583, \mathrm{df}=2 \text {; }\end{array}$ & $3 / 3$ mice \\
\hline S12J & $\begin{array}{lll}\text { Duration of } & \text { inter-male } \\
\text { aggression before } & \text { ASD and } \\
\text { after ASD during } & 1.51 \mathrm{~mW} \\
\text { laser stimulation } & \\
\end{array}$ & Paired t-test & $\begin{array}{l}\text { Before ASD: } 0 \pm 0 \text { vs } 1.873 \pm 0.309 \text { vs } \\
0.1032 \pm 0.05204 ; \text { After } \\
0.7698 \pm 0.3172 \text { vs } 0 \pm 0 ;\end{array}$ & $\begin{array}{l}\text { Before ASD vs After ASD: } * * P=0.0045 ; \mathrm{t} \\
=14.86, \mathrm{df}=2 ;\end{array}$ & 3 mice \\
\hline S12K & $\begin{array}{lll}\text { Events } & \text { of } & \text { inter-male } \\
\text { aggression before } & \text { ASD and } \\
\text { after ASD during } & 1.51 \mathrm{~mW} \\
\text { laser stimulation } & \\
\end{array}$ & Paired t-test & $\begin{array}{l}\text { Before ASD: } 0 \pm 0 \text { vs } 1.873 \pm 0.309 \text { vs } \\
0.1032 \pm 0.05204 ; \text { After } \\
0.7698 \pm 0.3172 \text { vs } 0 \pm 0 ;\end{array}$ & $\begin{array}{l}\text { Before ASD vs After ASD: } * * P=0.0022 ; \mathrm{t} \\
=21.20, \mathrm{df}=2 ;\end{array}$ & 3 mice \\
\hline S13E & $\begin{array}{l}\text { mCherry Group, Latency to } \\
\text { attack }\end{array}$ & $\begin{array}{l}\text { Wilcoxon matched- } \\
\text { pairs signed-rank } \\
\text { test and Paired t-test }\end{array}$ & $\begin{array}{l}\text { Pre-saline } v s \text { Saline } v s \text { Pre-CNO vs CNO: } \\
76.83 \pm 29.76 \quad \text { vs } 21.23 \pm 10.42 \quad \text { is } \\
7.017 \pm 4.198 \text { vs } 34.13 \pm 12.96\end{array}$ & $\begin{array}{l}\text { Pre-saline vs Saline: } P=0.1212 \mathrm{t}=1.865, \\
\mathrm{df}=5 \text {; Pre-CNO vs CNO: } P=0.1250 \\
\mathrm{~W}=13.00 \text {; Saline vs CNO: } P=0.4063 \\
\mathrm{~W}=9.000 \text {; }\end{array}$ & $\begin{array}{c}6 / 6 / 6 / 6 \\
\text { mice }\end{array}$ \\
\hline S13E & $\begin{array}{l}\text { HM4D Group, Latency to } \\
\text { attack }\end{array}$ & $\begin{array}{l}\text { Wilcoxon matched- } \\
\text { pairs signed-rank } \\
\text { test and Paired t-test }\end{array}$ & $\begin{array}{l}\text { Pre-saline } v s \text { Saline } v s \text { Pre-CNO vs CNO: } \\
112.3 \pm 57.78 \quad \text { vs } 32.48 \pm 8.039 \quad \text { vs } \\
22.91 \pm 7.128 \text { vs } 696.9 \pm 112.3\end{array}$ & $\begin{array}{l}\text { Pre-saline vs Saline: } P=0.171 \mathrm{t}=1.525, \\
\mathrm{df}=7 \text {; Pre-CNO vs CNO: } P=0.0078 \\
\mathrm{~W}=36.00 \text {; Saline vs CNO: } P=0.0078 \\
\mathrm{~W}=36.00 \text {; }\end{array}$ & $\begin{array}{c}8 / 8 / 8 / 8 \\
\text { mice }\end{array}$ \\
\hline S13E & $\begin{array}{l}\text { mCherry Group, Duration of } \\
\text { attack }\end{array}$ & $\begin{array}{l}\text { Wilcoxon matched- } \\
\text { pairs signed-rank } \\
\text { test and Paired t-test }\end{array}$ & $\begin{array}{l}\text { Pre-saline } v s \text { Saline } v s \text { Pre-CNO vs CNO: } \\
38.74 \pm 22.36 \quad \text { vs } \quad 40.26 \pm 21.74 \quad \text { v } \\
40.08 \pm 15.55 \text { vs } 26.06 \pm 10.31\end{array}$ & $\begin{array}{l}\text { Pre-saline vs Saline: } P=0.6004 \mathrm{t}=0.5589 \text {, } \\
\mathrm{df}=5 \text {; Pre-CNO vs CNO: } P=0.1563 \mathrm{~W}=- \\
\text { 15.00; Saline vs CNO: } P=0.5625 \mathrm{~W}=- \\
7.000 \text {; }\end{array}$ & $\begin{array}{c}6 / 6 / 6 / 6 \\
\text { mice }\end{array}$ \\
\hline S13E & $\begin{array}{l}\text { HM4D Group, Duration of } \\
\text { attack }\end{array}$ & $\begin{array}{l}\text { Wilcoxon matched- } \\
\text { pairs signed-rank } \\
\text { test and Paired t-test }\end{array}$ & $\begin{array}{l}\text { Pre-saline } v s \text { Saline } v s \text { Pre-CNO } v s \text { CNO: } \\
25.02 \pm 9.786 \quad v s \quad 13.29 \pm 3.847 \\
v s 20.4 \pm 5.443 \text { vs } 0.6363 \pm 0.3349\end{array}$ & $\begin{array}{l}\text { Pre-saline vs Saline: } P=0.1209 \mathrm{t}=1.765 \text {, } \\
\text { df=7; Pre-CNO vs CNO: } P=0.0078 \mathrm{~W}=- \\
36.00 \text {; Saline vs CNO: } P=0.0078 \mathrm{~W}=- \\
36.00 \text {; }\end{array}$ & $\begin{array}{c}8 / 8 / 8 / 8 \\
\text { mice }\end{array}$ \\
\hline S13E & $\begin{array}{l}\text { mCherry Group, Events of } \\
\text { attack }\end{array}$ & $\begin{array}{l}\text { Wilcoxon matched- } \\
\text { pairs signed-rank } \\
\text { test and Paired t-test }\end{array}$ & $\begin{array}{l}\text { Pre-saline } v s \text { Saline } v s \text { Pre-CNO vs CNO: } \\
25.17 \pm 13.02 \text { vs } \quad 32.83 \pm 15.61 \quad \text { vs } \\
40.83 \pm 8.412 \text { vs } 30.83 \pm 8.976\end{array}$ & $\begin{array}{l}\text { Pre-saline vs Saline: } P=0.999 \mathrm{~W}=1 \text {; Pre- } \\
\text { CNO vs CNO: } P=0.2662 \mathrm{t}=1.251, \mathrm{df}=5 \text {; } \\
\text { Saline } v s \text { CNO: } P=0.9118 \mathrm{t}=0.1165, \mathrm{df}=5\end{array}$ & $\begin{array}{c}6 / 6 / 6 / 6 \\
\text { mice }\end{array}$ \\
\hline S13E & $\begin{array}{l}\text { HM4D Group, Events of } \\
\text { attack }\end{array}$ & $\begin{array}{l}\text { Wilcoxon matched- } \\
\text { pairs signed-rank } \\
\text { test and Paired t-test }\end{array}$ & $\begin{array}{l}\text { Pre-saline } v s \text { Saline } v s \text { Pre-CNO } v s \text { CNO: } \\
33.75 \pm 5.314 \quad v s \quad 21.75 \pm 4.225 \quad v s \\
28.75 \pm 7.362 \text { vs } 1.625 \pm 0.9051\end{array}$ & $\begin{array}{l}\text { Pre-saline vs Saline: } P=0.0589 \mathrm{t}=2.253 \text {, } \\
\mathrm{df}=7 \text {; Pre-CNO vs CNO: } P=0.0078 \mathrm{~W}=- \\
36.00 \text {; Saline vs CNO: } P=0.0078 \mathrm{~W}=- \\
36.00 \text {; }\end{array}$ & $\begin{array}{c}8 / 8 / 8 / 8 \\
\text { mice }\end{array}$ \\
\hline S13I & $\begin{array}{l}\text { Number of induced action } \\
\text { potentials at different injected } \\
\text { current steps in CNO and } \\
\text { control group }\end{array}$ & Paired t-test & \begin{tabular}{lcr} 
Control vs CNO: & \multicolumn{2}{c}{$23 \pm 5.97216$ vs $0.5 \pm 0.5$} \\
$34.5 \pm 6.98212$ & vs & $1.75 \pm 1.03078$ \\
$44.5 \pm 7.55535$ & vs & $4.5 \pm 2.02073 ;$ \\
$49.25 \pm 7.40917$ & vs & $10.75 \pm 3.19831$ \\
$54.75 \pm 6.93271$ & vs & $14.5 \pm 3.52373$ \\
$58.5 \pm 7.35414$ & vs & $22.75 \pm 5.006$ \\
$57.25 \pm 8.23989$ vs & $25.5 \pm 5.63471$ \\
\end{tabular} & $\begin{array}{l}P=0.035, \mathrm{t}=3.67016, \quad \mathrm{df}=3 ; P=0.01968, \\
\mathrm{t}=4.56822, \mathrm{df}=3 ; P=0.01561, \mathrm{t}=4.97416, \\
\mathrm{df}=3 ; P=0.01299, \mathrm{t}=5.31773, \mathrm{df}=3 ; P= \\
0.0341, \quad \mathrm{t}=8.50516, \mathrm{df}=3 ; P=0.01502, \\
\mathrm{t}=5.04427, \quad \mathrm{df}=3 ; P=0.02032, \mathrm{t}=4.51379, \\
\mathrm{df}=3\end{array}$ & $\begin{array}{c}8 / 8 \\
\text { neurons }\end{array}$ \\
\hline S13J & $\begin{array}{l}\text { Minimal injected current to } \\
\text { induce action potential (APs) } \\
\text { induced in CNO and control } \\
\text { group }\end{array}$ & Paired t-test & $\begin{array}{l}\text { control vs } \quad \text { CNO: } \\
110 \pm 11.33893\end{array}$ & $P=0.002, \mathrm{t}=5.3513, \mathrm{df}=7$ & $\begin{array}{c}8 / 8 \\
\text { neurons }\end{array}$ \\
\hline S14F & $\begin{array}{l}\text { GtACR1 group in male-female } \\
\text { aggression }\end{array}$ & $\begin{array}{l}\text { Repeated one-way } \\
\text { ANOVA }\end{array}$ & $\begin{array}{l}\text { Pre vs Laser vs Post: } 1.508 \pm 0.1393 \text { vs } \\
1.342 \pm 0.2459 \text { vs } 0.323 \pm 0.08938\end{array}$ & $; \mathrm{F}(1.445,7.226)=14.98$ & $\begin{array}{c}6 / 6 / 6 \\
\text { mice }(6 \\
\text { from } 11 \\
\text { mice }) \\
\end{array}$ \\
\hline S14H & $\begin{array}{l}\text { GtACR1 group in female-male } \\
\text { aggression }\end{array}$ & Friedman test & $\begin{array}{l}\text { Pre vs Laser vs Post: } 1.166 \pm 0.7154 \text { vs } \\
0.4225 \pm 0.2947 \text { vs } 0.4098 \pm 0.4098\end{array}$ & $P=0.0417 ; \mathrm{FM}=6.500$ & $\begin{array}{l}4 / 4 / 4 \\
\text { mice }\end{array}$ \\
\hline S14M & Velocity in the open field test & Mann-Whitney test & $\begin{array}{l}\text { EYFP: } 6.396 \pm 0.7009 \text { vs } 6.024 \pm 0.2373 ; \\
\text { Laser: } 5.575 \pm 0.1351 \text { vs } 5.184 \pm 0.3435 ;\end{array}$ & $=0.1167 ; \mathrm{U}=3.000$ & $\begin{array}{c}3 / 3 / 7 / 7 \\
\text { mice }\end{array}$ \\
\hline S14N & $\begin{array}{l}\text { GtACR1 group in feeding } \\
\text { behavior: Latency to feeding } \\
\text { offset }\end{array}$ & Paired t-test & $\begin{array}{l}\text { Sham vs Laser: } 12.87 \pm 0.7207 \quad v s \\
10.88 \pm 0.6557 ;\end{array}$ & $P=0.0621 ; \mathrm{t}=2.218, \mathrm{df}=7$ & $\begin{array}{l}8 / 8 / 8 / 8 / 8 \\
18 \text { mice }\end{array}$ \\
\hline S14K & $\begin{array}{l}\text { GtACR1 } \text { group in feeding } \\
\text { behavior: } \\
\text { Percentage of of } \\
\text { feeding } \\
\text { trails interrupted } \\
\text { within } 3 \mathrm{~s}\end{array}$ & $\begin{array}{l}\text { Wilcoxon matched- } \\
\text { pairs signed-rank } \\
\text { test }\end{array}$ & $\begin{array}{l}\text { Sham vs } \quad \text { Laser: } \quad 9.375 \pm 4.838 \\
6.25 \pm 2.448 ;\end{array}$ & $P>0.9999 ; \mathrm{W}=-1$ & $\begin{array}{l}8 / 8 / 8 / 8 / 8 \\
/ 8 \text { mice }\end{array}$ \\
\hline
\end{tabular}


bioRxiv preprint doi: https://doi.org/10.1101/2020.04.22.047670; this version posted February 19, 2021. The copyright holder for this preprint (which was not certified by peer review) is the author/funder, who has granted bioRxiv a license to display the preprint in perpetuity. It is made available under aCC-BY-NC-ND 4.0 International license.

\begin{tabular}{|l|l|l|l|l|l|}
\hline S140 & $\begin{array}{l}\text { GtACR1 group in feeding } \\
\text { behavior: Duration of feeding }\end{array}$ & Paired t-test & $\begin{array}{l}\text { Sham: } 10.46 \pm 0.7456 \text { vs } 13.38 \pm 0.5353 \text { vs } \\
12.47 \pm 0.7705 ; \text { Laser: 11.27 } \pm 0.7477 \text { vs } \\
12.13 \pm 0.5694 \text { vs } 10.78 \pm 1.101 ;\end{array}$ & $\begin{array}{l}\text { Sham vs Laser: } P=0.0719 ; \mathrm{t}=2.118, \mathrm{df}= \\
7 ;\end{array}$ & $\begin{array}{c}8 / 8 / 8 / 8 / 8 \\
/ 8 \mathrm{mice}\end{array}$ \\
\hline \multirow{2}{*}{ S14P } & $\begin{array}{l}\text { GtACR1 group in feeding } \\
\text { behavior: Events of feeding }\end{array}$ & $\begin{array}{l}\text { Wilcoxon matched- } \\
\text { pairs signed-rank } \\
\text { test }\end{array}$ & $\begin{array}{l}\text { Sham: } 1.273 \pm 0.0971 \text { vs } 1.283 \pm 0.1394 \text { vs } \\
1.01 \pm 0.0865 ; \text { Laser: } 1.153 \pm 0.0553 \quad \text { vs } \\
1.359 \pm 0.0831 \text { vs } 1.056 \pm 0.0696 ;\end{array}$ & Sham vs Laser: $P=0.6094 ;$ W $=8 ;$ \\
\hline
\end{tabular}


bioRxiv preprint doi: https://doi.org/10.1101/2020.04.22.047670; this version posted February 19, 2021. The copyright holder for this preprint (which was not certified by peer review) is the author/funder, who has granted bioRxiv a license to display the preprint in perpetuity. It is made available under aCC-BY-NC-ND 4.0 International license.

Table S2. Functional manipulation studies of social behaviors from this paper

\begin{tabular}{|c|c|c|c|c|c|c|c|}
\hline Figures & $\begin{array}{c}\text { Tested Mice(Strain, } \\
\text { Sex,Social experience) }\end{array}$ & $\begin{array}{c}\text { Conditions(Opponents, } \\
\text { Environment) }\end{array}$ & $\begin{array}{c}\text { Manipulatio } \\
\text { n }\end{array}$ & Region & Cell-type & Attack & Mating \\
\hline Figure4A-C & $\begin{array}{l}\text { White socially adult virgin } \\
\text { Thy1-Cre male mice } \\
\text { (FVB/N) }\end{array}$ & $\begin{array}{l}\text { Single adult males (C57); } \\
\text { novel cage }\end{array}$ & $\begin{array}{l}\text { Chemogenetic } \\
\text { activation }\end{array}$ & pSI & $\mathrm{pSI}^{\text {Thy1 }}$ & $\begin{array}{l}\text { Enhanced } \\
\text { attack }\end{array}$ & No effect \\
\hline Figure4F-I & $\begin{array}{l}\text { Socially adult virgin males } \\
\text { (C57) }\end{array}$ & $\begin{array}{l}\text { Single adult males; home } \\
\text { cage }\end{array}$ & $\begin{array}{l}\text { Optogenetic } \\
\text { activation }\end{array}$ & $\mathrm{pSI}$ & $\mathrm{pSI}^{\mathrm{PAG}}$ & $\begin{array}{l}\text { Enhanced } \\
\text { attack }\end{array}$ & No effect \\
\hline Figure5B-C & $\begin{array}{ll}\text { Socially adult } & \text { virgin } \\
\text { females }(\mathbf{C 5 7}) & \\
\end{array}$ & $\begin{array}{l}\text { Single adult males; home } \\
\text { cage }\end{array}$ & $\begin{array}{l}\text { Optogenetic } \\
\text { activation }\end{array}$ & pSI & $\mathrm{pSI}^{-\mathrm{PAG}}$ & $\begin{array}{l}\text { Enhanced } \\
\text { attack }\end{array}$ & No effect \\
\hline Figure5D-E & $\begin{array}{l}\text { Single adult sexually- } \\
\text { experienced males }(\mathbf{C 5 7})\end{array}$ & Pups; home cage & $\begin{array}{l}\text { Optogenetic } \\
\text { activation }\end{array}$ & $\mathrm{pSI}$ & $\mathrm{pSI}^{-\mathrm{PAG}}$ & $\begin{array}{l}\text { Enhanced } \\
\text { attack }\end{array}$ & $\begin{array}{l}\text { Not } \\
\text { tested }\end{array}$ \\
\hline Figure5F-G & $\begin{array}{l}\text { Single adult virgin males } \\
\text { (C57) }\end{array}$ & $\begin{array}{l}\text { Moving gloves; home } \\
\text { cage }\end{array}$ & $\begin{array}{l}\text { Optogenetic } \\
\text { activation }\end{array}$ & pSI & $\mathrm{pSI}^{\mathrm{PAG}}$ & $\begin{array}{l}\text { Enhanced } \\
\text { attack }\end{array}$ & $\begin{array}{l}\text { Not } \\
\text { tested }\end{array}$ \\
\hline Figure5H-I & $\begin{array}{l}\text { Socially adult virgin males } \\
\text { (C57) }\end{array}$ & $\begin{array}{l}\text { Single adult CD-1 males; } \\
\text { CD-1's cage }\end{array}$ & $\begin{array}{l}\text { Optogenetic } \\
\text { activation }\end{array}$ & pSI & $\mathrm{pSI}^{-\mathrm{PAG}}$ & $\begin{array}{l}\text { Enhanced } \\
\text { attack }\end{array}$ & No effect \\
\hline Figure5J. 2nd & $\begin{array}{l}\text { Socially adult virgin males } \\
\text { (C57) }\end{array}$ & $\begin{array}{l}\text { Single adult males; novel } \\
\text { cage }\end{array}$ & $\begin{array}{l}\text { Optogenetic } \\
\text { activation }\end{array}$ & pSI & $\mathrm{pSI}^{-\mathrm{PAG}}$ & $\begin{array}{l}\text { Enhanced } \\
\text { attack }\end{array}$ & No effect \\
\hline Figure5J. 3rd & $\begin{array}{l}\text { Socially adult virgin males } \\
\text { (C57) }\end{array}$ & $\begin{array}{l}\text { Single adult males; } \\
\text { residents' cage }\end{array}$ & $\begin{array}{l}\text { Optogenetic } \\
\text { activation }\end{array}$ & $\mathrm{pSI}$ & $\mathrm{pSI}^{-\mathrm{PAG}}$ & $\begin{array}{l}\text { Enhanced } \\
\text { attack }\end{array}$ & No effect \\
\hline Figure5J. 4th & $\begin{array}{l}\text { Socially adult virgin males } \\
\text { (C57) }\end{array}$ & $\begin{array}{l}\text { Single adult males, cage- } \\
\text { mate; home cage }\end{array}$ & $\begin{array}{l}\text { Chemogenetic } \\
\text { activation }\end{array}$ & pSI & $\mathrm{pSI}^{-\mathrm{PAG}}$ & $\begin{array}{l}\text { Enhanced } \\
\text { attack }\end{array}$ & No effect \\
\hline Figure5J. 5th & $\begin{array}{l}\text { Single adult virgin males } \\
\text { (C57) }\end{array}$ & $\begin{array}{l}\text { Single adult males; home } \\
\text { cage }\end{array}$ & $\begin{array}{l}\text { Optogenetic } \\
\text { activation }\end{array}$ & pSI & $\mathrm{pSI}^{-\mathrm{PAG}}$ & $\begin{array}{l}\text { Enhanced } \\
\text { attack }\end{array}$ & No effect \\
\hline Figure5J. 6th & $\begin{array}{l}\text { Single adult virgin males } \\
\text { (C57) }\end{array}$ & $\begin{array}{l}\text { Single adult males; novel } \\
\text { cage }\end{array}$ & $\begin{array}{l}\text { Optogenetic } \\
\text { activation }\end{array}$ & pSI & $\mathrm{pSI}^{-\mathrm{PAG}}$ & $\begin{array}{l}\text { Enhanced } \\
\text { attack }\end{array}$ & No effect \\
\hline Figure5J. 7th & $\begin{array}{l}\text { Socially adult virgin males } \\
\text { (C57) }\end{array}$ & $\begin{array}{l}\text { Single adult females; } \\
\text { home cage }\end{array}$ & $\begin{array}{l}\text { Optogenetic } \\
\text { activation }\end{array}$ & pSI & $\mathrm{pSI}^{\mathrm{PAG}}$ & $\begin{array}{l}\text { Enhanced } \\
\text { attack }\end{array}$ & No effect \\
\hline Figure5J. 9th & $\begin{array}{l}\text { Socially adult } \\
\text { females }(\mathbf{C 5 7})\end{array}$ & $\begin{array}{l}\text { Single adult females; } \\
\text { home cage }\end{array}$ & $\begin{array}{l}\text { Optogenetic } \\
\text { activation }\end{array}$ & pSI & $\mathrm{pSI}^{-\mathrm{PAG}}$ & $\begin{array}{l}\text { Enhanced } \\
\text { attack }\end{array}$ & No effect \\
\hline Figure5J.12 $^{\text {nd }}$ & $\begin{array}{l}\begin{array}{l}\text { Socially } \\
\text { (C57) }\end{array} \\
\end{array}$ & Crickets; home cage & $\begin{array}{l}\text { Optogenetic } \\
\text { activation }\end{array}$ & pSI & $\mathrm{pSI}^{-\mathrm{PAG}}$ & $\begin{array}{l}\text { Enhanced } \\
\text { attack }\end{array}$ & $\begin{array}{l}\text { Not } \\
\text { tested }\end{array}$ \\
\hline Figure6 & $\begin{array}{l}\text { Socially adult virgin males } \\
\text { (C57) }\end{array}$ & $\begin{array}{l}\text { Single adult males; home } \\
\text { cage }\end{array}$ & $\begin{array}{l}\text { Chemogenetic } \\
\text { activation }\end{array}$ & pSI & $\mathrm{pSI}^{-\mathrm{PAG}}$ & $\begin{array}{l}\text { Enhanced } \\
\text { attack }\end{array}$ & No effect \\
\hline Figure6 & $\begin{array}{l}\text { Socially adult virgin males } \\
\text { (C57) }\end{array}$ & $\begin{array}{l}\text { Single adult females; } \\
\text { home cage }\end{array}$ & $\begin{array}{l}\text { Optogenetic } \\
\text { activation }\end{array}$ & pSI & pSI ${ }^{-P A G}$ & $\begin{array}{l}\text { Enhanced } \\
\text { attack }\end{array}$ & No effect \\
\hline Figure6 & $\begin{array}{ll}\text { Socially adult } & \text { virgin } \\
\text { females }(\mathbf{C 5 7}) & \\
\end{array}$ & $\begin{array}{l}\text { Single adult males; home } \\
\text { cage }\end{array}$ & $\begin{array}{l}\text { Optogenetic } \\
\text { activation }\end{array}$ & pSI & $\mathrm{pSI}^{-\mathrm{PAG}}$ & $\begin{array}{l}\text { Enhanced } \\
\text { attack }\end{array}$ & No effect \\
\hline Figure6 & $\begin{array}{l}\begin{array}{l}\text { Single adult sexually- } \\
\text { experienced males (C57) }\end{array} \\
\end{array}$ & Pups; home cage & $\begin{array}{l}\text { Optogenetic } \\
\text { activation }\end{array}$ & pSI & $\mathrm{pSI}^{-\mathrm{PAG}}$ & $\begin{array}{l}\text { Enhanced } \\
\text { attack }\end{array}$ & $\begin{array}{l}\text { Not } \\
\text { tested }\end{array}$ \\
\hline Figure6 & $\begin{array}{lll}\begin{array}{l}\text { Socially } \\
(\text { C57) }\end{array} & \text { housed males } \\
\end{array}$ & Crickets; home cage & $\begin{array}{l}\text { Optogenetic } \\
\text { activation }\end{array}$ & pSI & pSI $I^{-P A G}$ & $\begin{array}{l}\text { Enhanced } \\
\text { attack }\end{array}$ & $\begin{array}{l}\text { Not } \\
\text { tested }\end{array}$ \\
\hline Figure7A-C & $\begin{array}{l}\begin{array}{l}\text { Single adult } \\
\text { males }(\mathbf{F V B} / \mathbf{N})\end{array} \\
\end{array}$ & $\begin{array}{l}\begin{array}{l}\text { Socially adult males } \\
\text { (C57); home cage }\end{array} \\
\end{array}$ & $\begin{array}{l}\text { Chemogenetic } \\
\text { inhibition }\end{array}$ & pSI & $\mathrm{pSI}^{\text {Thy } 1}$ & $\begin{array}{l}\text { Reduced } \\
\text { attack }\end{array}$ & $\begin{array}{l}\text { Not } \\
\text { tested }\end{array}$ \\
\hline Figure7D-E & $\begin{array}{ll}\begin{array}{l}\text { Socially adult } \\
\text { experienced }\end{array} & \begin{array}{l}\text { sexually- } \\
\text { Thy1-Cre }\end{array} \\
\text { males (FVB/N) } & \\
\end{array}$ & $\begin{array}{l}\text { Socially adult females } \\
\text { (C57); home cage }\end{array}$ & $\begin{array}{l}\text { Chemogenetic } \\
\text { inhibition }\end{array}$ & pSI & $\mathrm{pSI}^{\text {Thy1 }}$ & $\begin{array}{l}\text { Not } \\
\text { tested }\end{array}$ & No effect \\
\hline Figure7F-N & 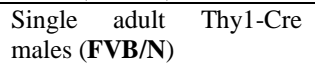 & $\begin{array}{l}\text { Socially adult males } \\
\text { (C57); home cage }\end{array}$ & $\begin{array}{l}\text { Optogenetic } \\
\text { inhibition }\end{array}$ & pSI & $\mathrm{pSI}^{\text {Thy1 }}$ & $\begin{array}{l}\text { Reduced } \\
\text { attack }\end{array}$ & $\begin{array}{l}\text { Not } \\
\text { tested }\end{array}$ \\
\hline Figure7F-N & $\begin{array}{l}\text { Single virgin adult Thy1- } \\
\text { Cre males }(\mathbf{F V B} / \mathbf{N})\end{array}$ & Pups; home cage & $\begin{array}{l}\text { Optogenetic } \\
\text { inhibition }\end{array}$ & $\mathrm{pSI}$ & $\mathrm{pSI}^{\text {Thyl }}$ & $\begin{array}{l}\text { Reduced } \\
\text { attack }\end{array}$ & $\begin{array}{l}\text { Not } \\
\text { tested }\end{array}$ \\
\hline Figure7F-N & $\begin{array}{lr}\begin{array}{l}\text { Single adult } \\
\text { males }(\mathbf{F V B} / \mathbf{N})\end{array} & \text { Thy1-Cre } \\
\end{array}$ & $\begin{array}{l}\begin{array}{l}\text { Crickets } \\
\text { cage }\end{array} \\
\end{array}$ & $\begin{array}{l}\text { Optogenetic } \\
\text { inhibition }\end{array}$ & pSI & pSI ${ }^{\text {Thy } 1}$ & $\begin{array}{l}\text { Reduced } \\
\text { attack }\end{array}$ & $\begin{array}{l}\text { Not } \\
\text { tested }\end{array}$ \\
\hline FigureS5 & $\begin{array}{l}\text { Socially adult virgin males } \\
\text { (C57) }\end{array}$ & $\begin{array}{l}\text { Single adult males; novel } \\
\text { cage }\end{array}$ & $\begin{array}{l}\text { Chemogenetic } \\
\text { activation }\end{array}$ & $\mathrm{pSI}$ & $\mathrm{pSI}^{-\mathrm{PAG}}$ & $\begin{array}{l}\text { Enhanced } \\
\text { attack }\end{array}$ & No effect \\
\hline FigureS6 & $\begin{array}{l}\text { Socially adult virgin males } \\
\text { (C57) }\end{array}$ & $\begin{array}{l}\text { Single adult males; home } \\
\text { cage }\end{array}$ & $\begin{array}{l}\text { Optogenetic } \\
\text { activation }\end{array}$ & pSI & $\mathrm{pSI}^{\mathrm{CaMKII} \alpha}$ & $\begin{array}{l}\text { Enhanced } \\
\text { attack }\end{array}$ & No effect \\
\hline FigureS7 & $\begin{array}{l}\text { Socially adult virgin Thy1- } \\
\text { Cre males }(\mathbf{F V B} / \mathbf{N})\end{array}$ & $\begin{array}{l}\text { Socially adult males; } \\
\text { home cage }\end{array}$ & $\begin{array}{l}\text { Optogenetic } \\
\text { activation }\end{array}$ & pSI & $\mathrm{pSI}^{\mathrm{CaMKII} \alpha}$ & $\begin{array}{l}\text { Enhanced } \\
\text { attack }\end{array}$ & No effect \\
\hline FigureS7 & $\begin{array}{l}\text { Socially adult virgin Thy1- } \\
\text { Cre males }(\mathbf{F V B} / \mathbf{N})\end{array}$ & Crickets; home cage & $\begin{array}{l}\text { Optogenetic } \\
\text { activation }\end{array}$ & pSI & $\begin{array}{l}\text { PAG } \\
\text { projecting } \\
\text { pSI }^{\text {Thy1 }}\end{array}$ & $\begin{array}{l}\text { Enhanced } \\
\text { attack }\end{array}$ & $\begin{array}{l}\text { Not } \\
\text { tested }\end{array}$ \\
\hline FigureS8 & $\begin{array}{l}\text { Socially adult virgin males } \\
\text { or females (C57) }\end{array}$ & $\begin{array}{l}\text { Single adult males or } \\
\text { females; home cage }\end{array}$ & $\begin{array}{l}\text { Optogenetic } \\
\text { activation }\end{array}$ & pSI & $\mathrm{pSI}^{\mathrm{CaMKII} \alpha}$ & $\begin{array}{l}\text { Enhanced } \\
\text { attack }\end{array}$ & No effect \\
\hline FigureS8 & $\begin{array}{l}\text { Socially adult virgin Thy1- } \\
\text { Cre males or females } \\
(\mathbf{F V B} / \mathbf{N})\end{array}$ & $\begin{array}{l}\text { Single adult males or } \\
\text { females (C57); novel cage }\end{array}$ & $\begin{array}{l}\text { Chemogenetic } \\
\text { activation }\end{array}$ & pSI & $\mathrm{pSI}^{\text {Thy1 }}$ & $\begin{array}{l}\text { Enhanced } \\
\text { attack }\end{array}$ & No effect \\
\hline FigureS10A-F & $\begin{array}{l}\text { Socially adult virgin males } \\
\text { (C57) }\end{array}$ & $\begin{array}{l}\text { Single adult males; home } \\
\text { cage }\end{array}$ & $\begin{array}{l}\text { Optogenetic } \\
\text { activation }\end{array}$ & PAG & $\begin{array}{l}\text { pSI } \\
\text { terminals in } \\
\text { PAG }\end{array}$ & $\begin{array}{l}\text { Enhanced } \\
\text { attack }\end{array}$ & No effect \\
\hline
\end{tabular}




\begin{tabular}{|c|c|c|c|c|c|c|c|}
\hline FigureS10A-E & $\begin{array}{l}\text { Socially adult virgin males } \\
\text { (C57) }\end{array}$ & $\begin{array}{l}\text { Single adult males; home } \\
\text { cage }\end{array}$ & $\begin{array}{l}\text { Optogenetic } \\
\text { activation }\end{array}$ & BNST & $\begin{array}{l}\text { pSI } \\
\text { terminals in } \\
\text { BNST }\end{array}$ & No effect & No effect \\
\hline FigureS10A-E & $\begin{array}{l}\text { Socially adult virgin males } \\
\text { (C57) }\end{array}$ & $\begin{array}{l}\text { Single adult males; home } \\
\text { cage }\end{array}$ & $\begin{array}{l}\text { Optogenetic } \\
\text { activation }\end{array}$ & VMH & $\begin{array}{l}\text { pSI } \\
\text { terminals in } \\
\text { VMH }\end{array}$ & No effect & No effect \\
\hline FigureS10G-K & $\begin{array}{l}\text { Adult virgin males (C57); } \\
\text { as for Fig. } 5\end{array}$ & As for Fig. 5 & $\begin{array}{l}\text { Optogenetic } \\
\text { activation }\end{array}$ & PAG & $\begin{array}{l}\text { pSI } \\
\text { terminals in } \\
\text { PAG }\end{array}$ & $\begin{array}{l}\text { Enhanced } \\
\text { attack }\end{array}$ & No effect \\
\hline $\begin{array}{l}\text { FigureS10 L- } \\
\mathbf{R}\end{array}$ & $\begin{array}{l}\text { Socially adult virgin males } \\
\text { or females (C57) }\end{array}$ & $\begin{array}{l}\text { Single adult males; home } \\
\text { cage }\end{array}$ & $\begin{array}{l}\text { Optogenetic } \\
\text { activation }\end{array}$ & PAG & $\begin{array}{l}\mathrm{pSI}^{\mathrm{CaMKII} \alpha} \\
\text { terminals in } \\
\text { PAG }\end{array}$ & $\begin{array}{l}\text { Enhanced } \\
\text { attack }\end{array}$ & No effect \\
\hline $\begin{array}{l}\text { FigureS10 L- } \\
\mathbf{R}\end{array}$ & $\begin{array}{l}\text { Socially adult virgin males } \\
\text { (C57) }\end{array}$ & $\begin{array}{l}\text { Single adult males; home } \\
\text { cage }\end{array}$ & $\begin{array}{l}\text { Optogenetic } \\
\text { activation }\end{array}$ & BNST & $\begin{array}{l}\mathrm{pSI}^{\mathrm{CaMKII} \alpha} \\
\text { terminals in } \\
\text { BNST }\end{array}$ & No effect & No effect \\
\hline FigureS12 & $\begin{array}{l}\text { Single adult sexually- } \\
\text { experienced males }(\mathbf{C 5 7})\end{array}$ & $\begin{array}{l}\text { Single adult males; home } \\
\text { cage; later in CD-1's cage } \\
\text { for ASD }\end{array}$ & $\begin{array}{l}\text { Optogenetic } \\
\text { activation }\end{array}$ & pSI & $\mathrm{pSI}^{-\mathrm{PAG}}$ & $\begin{array}{l}\text { Enhanced } \\
\text { attack, be } \\
\text { inhibited } \\
\text { by ASD }\end{array}$ & $\begin{array}{l}\text { Not } \\
\text { tested }\end{array}$ \\
\hline FigureS13A-E & $\begin{array}{l}\text { Single adult } \quad \text { sexually- } \\
\text { experienced males (C57) }\end{array}$ & $\begin{array}{l}\text { Socially adult males; } \\
\text { home cage }\end{array}$ & $\begin{array}{l}\text { Chemogenetic } \\
\text { inhibition }\end{array}$ & pSI & $\mathrm{pSI}^{-\mathrm{PAG}}$ & $\begin{array}{l}\text { Reduced } \\
\text { attack }\end{array}$ & $\begin{array}{l}\text { Not } \\
\text { tested }\end{array}$ \\
\hline FigureS14 & $\begin{array}{lcc}\text { Single } \quad \text { adult } & \text { Thy1-Cre } \\
\text { males }(\mathbf{F V B} / \mathbf{N}) & \\
\end{array}$ & $\begin{array}{l}\text { Socially adult females } \\
\text { (C57); home cage }\end{array}$ & $\begin{array}{l}\text { Optogenetic } \\
\text { inhibition }\end{array}$ & pSI & $\mathrm{pSI}^{\text {Thy1 }}$ & $\begin{array}{l}\text { Reduced } \\
\text { attack }\end{array}$ & $\begin{array}{l}\text { Not } \\
\text { tested }\end{array}$ \\
\hline FigureS14 & $\begin{array}{l}\text { Single adult } \text { Thy1-Cre } \\
\text { females }(\mathbf{F V B / N})\end{array}$ & $\begin{array}{l}\begin{array}{l}\text { Socially adult males } \\
\text { (C57); home cage }\end{array} \\
\end{array}$ & $\begin{array}{l}\text { Optogenetic } \\
\text { inhibition }\end{array}$ & pSI & $\mathrm{pSI}^{\text {Thy1 }}$ & $\begin{array}{l}\text { Reduced } \\
\text { attack }\end{array}$ & $\begin{array}{l}\text { Not } \\
\text { tested }\end{array}$ \\
\hline
\end{tabular}

'Enhanced attack' or 'reduced attack' indicates that the aggressive behavior during manipulation was significantly changed; 'No effect' indicates aggressive behavior during manipulation was not observed or was not significantly changed.

\section{REFERENCES}

ANDERSON, D. J. 2012. Optogenetics, sex, and violence in the brain: implications for psychiatry. Biol Psychiatry, 71, 1081-9.

ANDERSON, D. J. 2016. Circuit modules linking internal states and social behaviour in flies and mice. Nat Rev Neurosci, 17, 692-704.

ARBER, S. 2012. Motor circuits in action: specification, connectivity, and function. Neuron, 74, 975-89.

ARMBRUSTER, B. N., LI, X., PAUSCH, M. H., HERLITZE, S. \& ROTH, B. L. 2007. Evolving the lock to fit the key to create a family of $G$ protein-coupled receptors potently activated by an inert ligand. Proc Natl Acad Sci U SA, 104, 5163-8.

ASAHINA, K., WATANABE, K., DUISTERMARS, B. J., HOOPFER, E., GONZALEZ, C. R., EYJOLFSDOTTIR, E. A., PERONA, P. \& ANDERSON, D. J. 2014. Tachykinin-expressing neurons control male-specific aggressive arousal in Drosophila. Cell, 156, 221-35.

BEHBEHANI, M. M. 1995. Functional characteristics of the midbrain periaqueductal gray. Progress in Neurobiology, $46,575-605$.

BLANCHARD, D. C. \& BLANCHARD, R. J. 1988. Ethoexperimental approaches to the biology of emotion. Annual review of psychology, 39, 43-68.

BLANCHARD, R. J., WALL, P. M. \& BLANCHARD, D. C. 2003. Problems in the study of rodent aggression. Hormones and Behavior, 44, 161-170.

BOYDEN, E. S., ZHANG, F., BAMBERG, E., NAGEL, G. \& DEISSEROTH, K. 2005. Millisecond-timescale, genetically targeted optical control of neural activity. Nat Neurosci, 8, 1263-8.

CHEN, P. B., HU, R. K., WU, Y. E., PAN, L., HUANG, S., MICEVYCH, P. E. \& HONG, W. 2019. Sexually Dimorphic Control 
of Parenting Behavior by the Medial Amygdala. Cell, 176, 1206-1221.

CHEN, Y., LIN, Y. C., KUO, T. W. \& KNIGHT, Z. A. 2015. Sensory detection of food rapidly modulates arcuate feeding circuits. Cell, 160, 829-41.

COCCARO, E. F. 2012. Intermittent explosive disorder as a disorder of impulsive aggression for DSM-5. Am J Psychiatry, 169, 577-88.

CUI, Y., LV, G., JIN, S., PENG, J., YUAN, J., HE, X., GONG, H., XU, F., XU, T. \& LI, H. 2017. A Central Amygdala-Substantia Innominata Neural Circuitry Encodes Aversive Reinforcement Signals. Cell Rep, 21, 1770-1782.

DAVIDSON, R. J., PUTNAM, K. M. \& LARSON, C. L. 2000. Dysfunction in the neural circuitry of emotion regulation--a possible prelude to violence. Science, 289, 591-4.

DULAC, C., O'CONNELL, L. A. \& WU, Z. 2014. Neural control of maternal and paternal behaviors. Science, 345, 765770.

falkNeR, A. L., WeI, D., SONG, A., WATSEK, L. W., CHEN, I., CHEN, P., FENG, J. E. \& LIN, D. 2020. Hierarchical Representations of Aggression in a Hypothalamic-Midbrain Circuit. Neuron, 106, 637-648 e6.

FRANKLIN, K. B. \& PAXINOS, G. 2008. The mouse brain in stereotaxic coordinates, Academic press New York:.

GROVE, E. A. 1988a. Efferent connections of the substantia innominata in the rat. J Comp Neurol, 277, 347-64.

GROVE, E. A. 1988b. Neural associations of the substantia innominata in the rat: afferent connections. Journal of Comparative Neurology, 277, 315-346.

GUNAYDIN, L. A., GROSENICK, L., FINKELSTEIN, J. C., KAUVAR, I. V., FENNO, L. E., ADHIKARI, A., LAMMEL, S., MiRZABEKOV, J. J., AIRAN, R. D., ZALOCUSKY, K. A., TYE, K. M., ANIKEeVA, P., MALENKA, R. C. \& DEISSEROTH, K. 2014. Natural neural projection dynamics underlying social behavior. Cell, 157, 1535-51.

hAN, W., TElLEZ, L. A., RANGEL, M. J., JR., MOTTA, S. C., ZHANG, X., PEREZ, I. O., CANTERAS, N. S., SHAMMAHLAGNADO, S. J., VAN DEN POL, A. N. \& DE ARAUJO, I. E. 2017. Integrated Control of Predatory Hunting by the Central Nucleus of the Amygdala. Cell, 168, 311-324 e18.

HASHIKAWA, K., HASHIKAWA, Y., LISCHINSKY, J. \& LIN, D. 2018. The Neural Mechanisms of Sexually Dimorphic Aggressive Behaviors. Trends Genet, 34, 755-776.

HASHIKAWA, K., HASHIKAWA, Y., TREMBLAY, R., ZHANG, J., FENG, J. E., SABOL, A., PIPER, W. T., LEE, H., RUDY, B. \& LIN, D. 2017. Esr1(+) cells in the ventromedial hypothalamus control female aggression. Nat Neurosci, 20, 1580-1590.

HEIMER, L., HARLAN, R. E., ALHEID, G. F., GARCIA, M. M. \& DE OLMOS, J. 1997. Substantia innominata: a notion which impedes clinical-anatomical correlations in neuropsychiatric disorders. Neuroscience, 76, 957-1006.

HONG, W., KIM, D. W. \& ANDERSON, D. J. 2014. Antagonistic control of social versus repetitive self-grooming behaviors by separable amygdala neuronal subsets. Cell, 158, 1348-1361.

ISOGAI, Y., WU, Z., LOVE, M. I., AHN, M. H., BAMBAH-MUKKU, D., HUA, V., FARRELL, K. \& DULAC, C. 2018. Multisensory Logic of Infant-Directed Aggression by Males. Cell, 175, 1827-1841 e17.

KIM, Y., VENKATARAJU, K. U., PRADHAN, K., MENDE, C., TARANDA, J., TURAGA, S. C., ARGANDA-CARRERAS, I., NG, L., HAWRYLYCZ, M. J., ROCKLAND, K. S., SEUNG, H. S. \& OSTEN, P. 2015. Mapping social behavior-induced 
brain activation at cellular resolution in the mouse. Cell Rep, 10, 292-305.

KOHL, J., BABAYAN, B. M., RUBINSTEIN, N. D., AUTRY, A. E., MARIN-RODRIGUEZ, B., KAPOOR, V., MIYAMISHI, K., ZWEIFEL, L. S., LUO, L., UCHIDA, N. \& DULAC, C. 2018. Functional circuit architecture underlying parental behaviour. Nature, 556, 326-331.

LEE, H., KIM, D. W., ReMEDIOS, R., ANTHONY, T. E., CHANG, A., MADISEN, L., ZENG, H. \& ANDERSON, D. J. 2014. Scalable control of mounting and attack by Esr1+ neurons in the ventromedial hypothalamus. Nature, 509, 627-32.

LI, Y., ZENG, J., ZHANG, J., YUE, C., ZHONG, W., LIU, Z., FENG, Q. \& LUO, M. 2018. Hypothalamic Circuits for Predation and Evasion. Neuron, 97, 911-924 e5.

LIN, D., BOYLE, M. P., DOLLAR, P., LEE, H., LEIN, E. S., PERONA, P. \& ANDERSON, D. J. 2011. Functional identification of an aggression locus in the mouse hypothalamus. Nature, 470, 221-6.

LIN, L., CHEN, G., KUANG, H., WANG, D. \& TSIEN, J. Z. 2007. Neural encoding of the concept of nest in the mouse brain. Proc Natl Acad Sci U S A, 104, 6066-71.

LISCHINSKY, J. E. \& LIN, D. 2020. Neural mechanisms of aggression across species. Nat Neurosci, 23, 1317-1328.

MCCLOSKEY, M. S., PHAN, K. L., ANGSTADT, M., FETTICH, K. C., KEEDY, S. \& COCCARO, E. F. 2016. Amygdala hyperactivation to angry faces in intermittent explosive disorder. J Psychiatr Res, 79, 34-41.

MOS, J., KRUK, M., VAN POEL, A. D. \& MEELIS, W. 1982. Aggressive behavior induced by electrical stimulation in the midbrain central gray of male rats. Aggressive Behavior, 8, 261-284.

MOYER, K. E. 1968. Kinds of aggression and their physiological basis. Communications in Behavioral Biology, 2(2): 65-87.

NELSON, R. J. \& TRAINOR, B. C. 2007. Neural mechanisms of aggression. Nat Rev Neurosci, 8, 536-46.

PADILLA, S. L., QIU, J., SODEN, M. E., SANZ, E., NESTOR, C. C., BARKER, F. D., QUINTANA, A., ZWEIFEL, L. S., RONNEKLEIV, O. K., KELLY, M. J. \& PALMITER, R. D. 2016. Agouti-related peptide neural circuits mediate adaptive behaviors in the starved state. Nat Neurosci, 19, 734-741.

PARK, S. G., JEONG, Y. C., KIM, D. G., LEE, M. H., SHIN, A., PARK, G., RYOO, J., HONG, J., BAE, S., KIM, C. H., LEE, P. S. \& KIM, D. 2018. Medial preoptic circuit induces hunting-like actions to target objects and prey. Nat Neurosci, 21, 364-372.

SHANG, C., LIU, A., LI, D., XIE, Z., CHEN, Z., HUANG, M., LI, Y., WANG, Y., SHEN, W. L. \& CAO, P. 2019. A subcortical excitatory circuit for sensory-triggered predatory hunting in mice. Nat Neurosci, 22, 909-920.

SIEGEL, A. \& VICTOROFF, J. 2009. Understanding human aggression: New insights from neuroscience. Int J Law Psychiatry, 32, 209-15.

TERVO, D. G., HWANG, B. Y., VISWANATHAN, S., GAJ, T., LAVZIN, M., RITOLA, K. D., LINDO, S., MICHAEL, S., KULESHOVA, E., OJALA, D., HUANG, C. C., GERFEN, C. R., SCHILLER, J., DUDMAN, J. T., HANTMAN, A. W., LOOGER, L. L., SCHAFFER, D. V. \& KARPOVA, A. Y. 2016. A Designer AAV Variant Permits Efficient Retrograde Access to Projection Neurons. Neuron, 92, 372-382.

TINBERGEN, N. 1951. The study of instinct. 
TOVOTE, P., ESPOSITO, M. S., BOTTA, P., CHAUDUN, F., FADOK, J. P., MARKOVIC, M., WOLFF, S. B., RAMAKRISHNAN, C., FENNO, L., DEISSEROTH, K., HERRY, C., ARBER, S. \& LUTHI, A. 2016. Midbrain circuits for defensive behaviour. Nature, 534, 206-12.

WANG, L., CHEN, I. Z. \& LIN, D. 2015. Collateral pathways from the ventromedial hypothalamus mediate defensive behaviors. Neuron, 85, 1344-58.

WEI, Y. C., WANG, S. R., JIAO, Z. L., ZHANG, W., LIN, J. K., LI, X. Y., LI, S. S., ZHANG, X. \& XU, X. H. 2018. Medial preoptic area in mice is capable of mediating sexually dimorphic behaviors regardless of gender. Nat Commun, 9, 279.

WU, Z., AUTRY, A. E., BERGAN, J. F., WATABE-UCHIDA, M. \& DULAC, C. G. 2014. Galanin neurons in the medial preoptic area govern parental behaviour. Nature, 509, 325-30.

XU, X., COATS, J. K., YANG, C. F., WANG, A., AHMED, O. M., ALVARADO, M., IZUMI, T. \& SHAH, N. M. 2012. Modular genetic control of sexually dimorphic behaviors. Cell, 148, 596-607.

YANG, C. F., CHIANG, M. C., GRAY, D. C., PRABHAKARAN, M., ALVARADO, M., JUNTTI, S. A., UNGER, E. K., WElLS, J. A. \& SHAH, N. M. 2013. Sexually dimorphic neurons in the ventromedial hypothalamus govern mating in both sexes and aggression in males. Cell, 153, 896-909.

YANG, T., YANG, C. F., CHIZARI, M. D., MAHESWARANATHAN, N., BURKE, K. J., JR., BORIUS, M., INOUE, S., CHIANG, M. C., BENDER, K. J., GANGULI, S. \& SHAH, N. M. 2017. Social Control of Hypothalamus-Mediated Male Aggression. Neuron, 95, 955-970 e4.

YU, K., AHRENS, S., ZHANG, X., SCHIFF, H., RAMAKRISHNAN, C., FENNO, L., DEISSEROTH, K., ZHAO, F., LUO, M.-H., GONG, L., HE, M., ZHOU, P., PANINSKI, L. \& LI, B. 2017. The central amygdala controls learning in the lateral amygdala. Nature Neuroscience, 20, 1680-1685.

ZELIKOWSKY, M., HUI, M., KARIGO, T., CHOE, A., YANG, B., BLANCO, M. R., BEADLE, K., GRADINARU, V., DEVERMAN, B. E. \& ANDERSON, D. J. 2018. The Neuropeptide Tac2 Controls a Distributed Brain State Induced by Chronic Social Isolation Stress. Cell, 173, 1265-1279 e19.

ZHAO, Z. D., CHEN, Z., XIANG, X., HU, M., XIE, H., JIA, X., CAI, F., CUI, Y., CHEN, Z., QIAN, L., LIU, J., SHANG, C., YANG, Y., NI, X., SUN, W., HU, J., CAO, P., LI, H. \& SHEN, W. L. 2019. Zona incerta GABAergic neurons integrate prey-related sensory signals and induce an appetitive drive to promote hunting. Nat Neurosci, 22, 921-932.

ZINGG, B., CHOU, X. L., ZHANG, Z. G., MESIK, L., LIANG, F., TAO, H. W. \& ZHANG, L. I. 2017. AAV-Mediated Anterograde Transsynaptic Tagging: Mapping Corticocollicular Input-Defined Neural Pathways for Defense Behaviors. Neuron, 93, 33-47. 